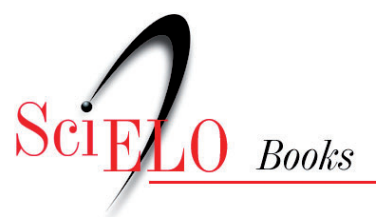

\title{
Atenção diferenciada \\ a formação técnica de agentes indígenas de saúde do Alto Rio Negro
}

\author{
Luiza Garnelo
}

Sully de Souza Sampaio

Ana Lúcia Pontes

\section{SciELO Books / SciELO Livros / SciELO Libros}

GARNELO, L., SAMPAIO, S.S., and PONTES, A.L. Atenção diferenciada: a formação técnica de agentes indígenas de saúde do Alto Rio Negro [online]. Rio de Janeiro: Editora FIOCRUZ, 2019, 163 p. Fazer saúde collection. ISBN: 978-65-5708-011-5. https://doi.org/10.7476/9786557080115.

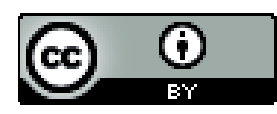

All the contents of this work, except where otherwise noted, is licensed under a Creative Commons Attribution $\underline{4.0 \text { International license. }}$

Todo o conteúdo deste trabalho, exceto quando houver ressalva, é publicado sob a licença $\underline{\text { Creative Commons }}$ Atribição 4.0. 


\section{Atenção diferenciada}

a formação técnica de agentes indígenas de saúde do Alto Rio Negro 


\section{FUNDAÇÃO OSWALDO CRUZ}

Presidente

Nísia Trindade Lima

Vice-Presidente de Educação, Informação e Comunicação

Cristiani Vieira Machado

\section{Editora Fiocruz}

Diretora

Cristiani Vieira Machado

Editor Executivo

João Carlos Canossa Mendes

Editores Científicos

Carlos Machado de Freitas

Gilberto Hochman

Conselho Editorial

Denise Valle

José Roberto Lapa e Silva

Kenneth Rochel de Camargo Jr.

Ligia Maria Vieira da Silva

Marcos Cueto

Maria Cecília de Souza Minayo

Marilia Santini de Oliveira

Moisés Goldbaum

Rafael Linden

Ricardo Ventura Santos

Coleção Fazer Saúde

Editores Responsáveis

Carlos Machado de Freitas

Luis Eugenio Portela Fernandes de Souza 


\section{Atenção diferenciada a formação técnica de agentes indígenas de saúde do Alto Rio Negro}

Luiza Garnelo

Sully de Souza Sampaio

Ana Lúcia Pontes

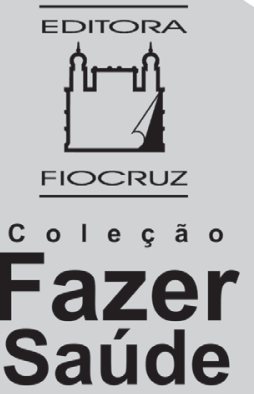


Copyright (c) 2019 dos autores

Todos os direitos desta edição reservados à

FUNDAÇÃO OSWALDO CRUZ / EDITORA

Esta publicação recebeu apoio financeiro da Vice-Presidência de Ambiente, Atenção e Promoção da Saúde da Fundação Oswaldo Cruz (Fiocruz), por meio de cooperação técnica com a Secretaria Especial de Saúde Indígena do Ministério da Saúde; do Instituto Leônidas \& Maria Deane da Fiocruz Amazônia e do projeto Formação Profissional do Agente Indígena de Saúde: contextos e discursos do Programa de Apoio à Pesquisa Estratégica em Saúde (PAPES VII) do Conselho Nacional de Desenvolvimento Científico e Tecnológico.

\section{Revisão}

Augusta Porto Avalle, Myllena Paiva e Thaís Pedretti

Normalização de referências Clarissa Bravo

Projeto gráfico
Daniel Pose

\section{Capa e editoração Carlos Fernando Reis}

Imagem de capa Ana Lúcia Pontes

Produção editorial Phelipe Casiglia

Catalogação na fonte Instituto de Comunicação e Informação Científica e Tecnológica em Saúde/Fiocruz Biblioteca de Saúde Pública

A864a Atenção diferenciada: a formação técnica de agentes indígenas de saúde do Alto Rio Negro / Luiza Garnelo, Sully Sampaio e Ana Lúcia Pontes. - Rio de Janeiro: Editora Fiocruz, 2019.

$$
164 \text { p. : il. (Coleção Fazer Saúde) }
$$

ISBN: 978-85-754I-634-I

1. Agentes Comunitários de Saúde - educação. 2. Serviços de Saúde do Indígena. 3. Capacitação de Recursos Humanos em Saúde. 4. Vigilância Nutricional. 5. Índios Sul-Americanos. 6. Saúde da Criança. 7. Saúde do Adulto. I. Garnelo, Luiza. II. Sampaio, Sully. III. Pontes, Ana Lúcia de Moura. IV. Título.

CDD - 23.ed. -980.41

\section{9}

EDITORA FIOCRUZ

Av. Brasil, 4036, térreo, sala 112 - Manguinhos

21040-36 I - Rio de Janeiro, RJ

Tels: (2 I) 3882-9039 e 3882-904 I

Telefax: (2I) 3882-9006

editora@fiocruz.br

www.fiocruz.br/editora

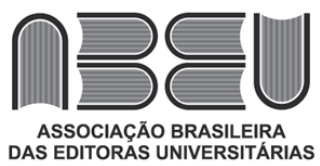




\section{Autores}

\section{Luiza Garnelo}

Médica-sanitarista e antropóloga, doutora em ciências sociais/antropologia pela Universidade Estadual de Campinas; pesquisadora do Instituto Leônidas E Maria Deane da Fundação Oswaldo Cruz.

Sully de Souza Sampaio

Cientista social; bolsista do Instituto Leônidas \& Maria Deane da Fundação Oswaldo Cruz.

\section{Ana Lúcia Pontes}

Médica-sanitarista, doutora em saúde pública pela Escola Nacional de Saúde Pública Sergio Arouca da Fundação Oswaldo Cruz (Ensp/Fiocruz); pesquisadora da Ensp/Fiocruz. 


\section{Sumário}

Apresentação

I O trabalho e a formação dos agentes comunitários de saúde e dos agentes indígenas de saúde

Trabalhadores comunitários da saúde: reflexões com base nas primeiras experiências implementadas no mundo

Trabalhadores comunitários no Brasil e a regulamentação profissional dos ACS

A estruturação da APS para os povos indígenas e os AIS

2 Concepções político-pedagógicas, interculturalidade e organização curricular do Curso Técnico de Agentes Comunitários Indígenas de Saúde

Contexto e histórico da experiência

Educação escolar indígena e a perspectiva crítica de interculturalidade

Profissionalização, intermedicalidade e atenção diferenciada

Diretrizes para a formação do AIS e a escolha do perfil profissional 34

A organização curricular do CTACIS

Estrutura e conteúdos curriculares do CTACIS

Outras reflexões sobre o currículo em ação

3 Temas transversais: território, cultura e política

Eixo transversal Território

Eixo transversal Cultura

Eixo transversal Política 
4 Cuidado e vigilância alimentar e nutricional em terra indígena

Ações formativas adotadas para o campo da vigilância alimentar e nutricional

Algumas considerações sobre o processo, os resultados e as dificuldades no desenvolvimento das ações formativas em vigilância alimentar e nutricional 86

Reflexões sobre as potencialidades e os desafios encontrados

5 Cuidado à saúde da criança indígena

Implementação curricular dos componentes relativos à saúde da criança indígena no CTACIS

6 Dimensões da saúde do adulto: o cuidado à saúde da mulher indígena

Oferta de cuidados à saúde da mulher indígena

Novas atribuições do AIS em saúde da mulher

7 Aprendizados gerados pela experiência e potencialidades de adaptação para outros contextos 


\section{Apresentação}

Em novembro de 2016, no editorial do Boletim da Organização Mundial da Saúde (OMS) Maher e Cometto (2016) destacaram a importância dos trabalhadores comunitários de saúde (TCS), conhecidos no Brasil como agentes comunitários de saúde (ACS) e agentes indígenas de saúde (AIS), para o alcance do acesso universal aos serviços de saúde e para a distribuição equitativa de ações de promoção da saúde, prevenção de doenças e ações curativas, principalmente no âmbito da saúde materno-infantil e das infecções transmissíveis. Os autores salientaram a necessidade de análises mais consistentes sobre os fatores contextuais e condições facilitadoras para a atuação dos trabalhadores comunitários da saúde, tais como educação, regulamentação profissional, supervisão e motivação (Maher \& Cometto, 2016).

Esse editorial foi precedido por uma consulta pública feita pela OMS, também em 2016, acerca do perfil de trabalho e formação dos TCS em todo o mundo, com o intuito de subsidiar a produção de orientações para o fortalecimento dos programas baseados em TCS nos sistemas e políticas públicas de saúde. Dessa forma, claramente observamos uma retomada da discussão do lugar estratégico dos TCS nos sistemas de saúde, ponto muito ressaltado no Informe da OMS sobre a Conferência Internacional sobre Atenção Primária à Saúde (APS), em 1978. No fim de 2018, como produto dessa retomada, a OMS lança o Guideline on Health Policy and System Support to Optimise Community Health Worker Programmes (em português, Diretrizes para Políticas de Saúde e Apoio aos Sistemas para Otimizar Programas de Trabalhadores Comunitários de Saúde), baseado em revisões sistemáticas de evidências, visando potencializar a atuação dos TCS nos sistemas de saúde.

O Brasil tem contribuído de forma importante nesse debate, tanto na formulação e implementação de políticas públicas quanto no desenvolvimento de pesquisas científicas. A expansão da Estratégia Saúde da Família (ESF) alcançou, em dezembro de 2016, a contratação de 272 mil ACS no país, que atendem a 66,55\% da população 
brasileira. As universidades e instituições acadêmicas atentas a esse processo atuaram no desenvolvimento de diversos projetos e iniciativas para apoio ao trabalho e formação dos ACS e investigação sobre essa temática.

Neste livro nos debruçamos sobre a formação e o trabalho do AIS, um trabalhador comunitário que atua em áreas indígenas no Brasil desde a década de 1980. Apesar das aproximações históricas entre os AIS e os ACS, os AIS permanecem isolados e invisíveis para o restante do Sistema Único de Saúde (SUS). Os AIS são os únicos profissionais a permitirem um contato regular e constante da população indígena moradora de terras indígenas (TIs) aos serviços públicos de saúde. Estima-se que no Subsistema de Atenção à Saúde Indígena (Sasi-SUS) existam cerca de seis mil AIS, que atendem aproximadamente 700 mil pessoas; eles integram formalmente as equipes de saúde que atuam em 34 Distritos Sanitários Especiais Indígenas (DSEls).

A iniciativa apresentada nessa publicação foi a primeira no Brasil a efetivar a elevação da escolaridade de nível médio e formação profissional técnica de AIS, direcionando seus esforços pedagógicos para atender também às premissas da interculturalidade. Em razão da singular dinâmica assumida pelo curso, a experiência foi selecionada como uma das 23 iniciativas inovadoras em saúde no mundo pelo Projeto de Inovação Social em Saúde (Social Innovation in Health Initiative) do Special Programme for Research and Training in Tropical Diseases (TDR) da OMS, Universidade de Oxford e Bertha Centre/Universidade da Cidade do Cabo, em 2014 (Disponível em: < https://socialinnovationinhealth.org>).

Discutimos o processo de construção e implementação do Curso Técnico de Agentes Comunitários Indígenas de Saúde (CTACIS), desenvolvido entre 2007 e 2015 , voltado para os AIS que atuam no DSEI do Alto Rio Negro (DSEI-RN). O projeto foi desenvolvido em parceria estabelecida entre as seguintes instituições: Federação das Organizações Indígenas do Rio Negro (FOIRN), DSEI-RN/Secretaria Especial de Saúde Indígena, Secretaria Municipal de Educação (Semec) e de Saúde (Semsa) de São Gabriel da Cachoeira (Amazonas/AM), Secretaria de Estado do Amazonas de Educação e Qualidade do Ensino através da Gerência de Educação Escolar Indígena (Seduc/Departamento de Política e Programas Educacionais/Gerência de Educação Escolar Indígena), Secretaria de Educação Continuada, Alfabetização, Diversidade e Inclusão (Secadi/Ministério da Educação), Instituto Leônidas \& Maria Deane (ILMD da Fundação Oswaldo Cruz/ Fiocruz Amazônia) e Escola Politécnica de Saúde Joaquim Venâncio (EPSJV/Fiocruz).

A organização do curso segue as orientações do Referencial Curricular para Curso Técnico de Agente Comunitário de Saúde, desenvolvido pelo Ministério da Saúde e Ministério da Educação (2004), que instituiu os parâmetros curriculares para a organização de cursos técnicos para os ACS. Entendemos que os marcos para criação 
e consolidação do papel dos AIS na equipe multidisciplinar no DSEl se estruturam em consonância com as propostas de organização da Atenção Básica à Saúde no SUS. Assim sendo, os dois modos de oferta de cuidados em saúde guardam muitas semelhanças entre si, favorecendo o uso dos marcos referenciais que orientam o processo formador dos ACS (não indígenas) no desenho da profissionalização dos indígenas, e vice-versa.

O currículo foi construído de forma flexível, em processo, na busca de melhor atender às especificidades indígenas e às características organizativas do sistema local de saúde do DSEl Alto Rio Negro. Entendemos que a organização curricular reformulada ao longo do curso mostrou-se mais sensível e adequada para atender às necessidades de formação de ensino técnico para indígenas que atuam como agentes comunitários.

Além de realizar o relato da experiência desenvolvida, refletimos sobre a organização do trabalho, o modelo de atenção e os processos formativos com populações indígenas. Ou seja, nos aprofundamos nos fatores contextuais e condições facilitadoras para o fortalecimento da atuação dos AIS, discutindo tanto sua atuação nas comunidades indígenas quanto sua inserção nas equipes multidisciplinares de saúde indígena.

Apesar da especificidade do local de desenvolvimento de nossa experiência e do projeto educativo, pretendemos que as discussões tragam contribuições e sugestões que possam ser adaptadas e implementadas em outros contextos indígenas e na rede de Atenção Primária à Saúde (APS) do SUS.

A organização do livro toma como eixos centrais a dinâmica da implementação curricular e as reflexões sobre a construção de um perfil profissional para os Técnicos em Agente Comunitário Indígena de Saúde. No capítulo I, "O trabalho e a formação dos agentes comunitários de saúde e dos agentes indígenas de saúde”, apresentamos o contexto mundial e nacional da emergência desses trabalhadores comunitários de saúde e os panoramas e diretrizes nacionais para o trabalho e a formação de agentes comunitários de saúde e agentes indígenas de saúde.

No capítulo 2, "Concepções político-pedagógicas, interculturalidade e organização curricular do Curso Técnico de Agentes Comunitários Indígenas de Saúde", apresentamos os debates teóricos que subsidiaram a construção da proposta de curso, com ênfase nas reflexões do campo da educação escolar indígena, interculturalidade e intermedicalidade. Também fazemos a descrição da estrutura curricular do curso e discutimos aspectos gerais da implementação da proposta na perspectiva intercultural.

Na construção curricular, enfatizam-se algumas dimensões teórico-metodológicas que perpassam o processo formativo. Tal concepção é exemplificada no capítulo 3 , intitulado "Temas transversais: território, cultura e política". 
No capítulo 4, referente ao "Cuidado e vigilância alimentar e nutricional em terra indígena" destacamos as estratégias pedagógicas utilizadas para propor atribuições do AIS em ações de vigilância alimentar e nutricional, problematizando as especificidades socioculturais do contexto indígena.

Encontramos no capítulo 5, intitulado "Cuidado à saúde da criança indígena", o relato sobre a abordagem curricular das dimensões socioculturais da infância e do cuidado à criança nas comunidades indígenas e a construção de novas atribuições para os AIS no cuidado à saúde das crianças indígenas.

O capítulo 6, "Dimensões da saúde do adulto: o cuidado à saúde da mulher indígena", aprofunda as reflexões e desafios na abordagem da saúde reprodutiva da mulher indígena. O capítulo 7, "Aprendizados gerados pela experiência e potencialidades de sua adaptação para outros contextos", reflete sobre lições aprendidas e potencialidades para realização do curso em outros contextos indígenas e com populações rurais de municípios de pequeno porte. Nesse último capítulo apresentamos o conjunto das atribuições profissionais sugeridas para o Técnico Agente Comunitário Indígena de Saúde. 


\section{O trabalho e a formação dos agentes comunitários de saúde $e$ dos agentes indígenas de saúde}

As formações profissionais em saúde, ao tomarem o trabalho como eixo para a construção curricular, provocam reflexões acerca do papel social dos trabalhadores. Inicialmente, gostaríamos de destacar que o debate sobre o papel e a profissionalização dos AIS se articula com a trajetória dos trabalhadores de nível médio e fundamental da saúde. Esses trabalhadores estão inseridos na moderna divisão social do trabalho no mundo capitalista, a qual limitou sua atuação às atividades manuais e rebaixou seu trabalho ao plano da baixa complexidade. Fica subentendido que sua qualificação dispensa a inserção de fundamentos teóricos, as remunerações para tais cargos são baixas e eles ocupam uma posição subalterna na hierarquia dos profissionais da saúde.

Entretanto, principalmente a partir da década de 1980, o movimento de regulamentação das profissões de nível técnico e elementar potencializou a constituição do campo da educação profissional em saúde. As perspectivas críticas desse campo se contrapõem a essa visão naturalizada da divisão social do trabalho e partem de uma concepção na qual se compreende o trabalhador como sujeito transformador de sua realidade. É a partir dessa perspectiva que buscamos desenvolver a profissionalização dos AIS.

Porém, observamos que na atuação dos AIS, assim como Silva e Dalmaso (200 I : 180) descreveram no caso dos ACS, "o agente não dispõe de instrumentos, de tecnologia, de saberes para corresponder às expectativas das comunidades e dos governos". Sem uma definição da sua área de saber e de prática, os AIS encontram muitos desafios para seu reconhecimento profissional e para a qualidade e efetividade de suas ações nas comunidades onde atuam.

Para melhor compreensão das questões que perpassam esses desafios na formação profissional dos AIS, consideramos fundamental contextualizar como tem se construído 
o papel dos TCS no mundo, e, no Brasil, especificamente, dos ACS, pois seus marcos influenciaram diretamente a experiência em análise. Também faremos uma breve apresentação do subsistema de saúde indígena e do panorama da formação e trabalho dos AIS no Brasil.

\section{Trabalhadores comunitários da saúde: reflexões com base nas primeiras experiências implementadas no mundo}

Para revermos a atuação dos TCS durante o primeiro período de expansão da APS, usaremos dados da revisão internacional, publicada em 1990, intitulada Community Health Workers in National Programmes: just another pair of hands? (em português, Trabalhadores Comunitários em Saúde nos Programas Nacionais: apenas um par extra de mãos?). Essa retomada é importante para analisarmos as marcas históricas que tendem a persistir no papel desses trabalhadores e identificarmos os limites na atuação dos TCS sem profissionalização.

Os autores ressaltam que o termo trabalhadores comunitários de saúde foi difundido a partir de 1975 e agregou vários tipos e perfis de trabalhadores que tinham como característica comum serem pessoas provenientes e residentes das comunidades nas quais desenvolviam ações de saúde. A difusão da APS a partir da Conferência Internacional de Cuidados Primários à Saúde em 1978 levou vários países a promoverem programas de TCS, que tinham em comum dois objetivos: estender as ações de saúde para populações não assistidas e envolver membros das comunidades nesses programas (Walt et al., 1990).

Walt e colaboradores (1990) relatam que os primeiros programas de TCS foram inspirados em relatórios de profissionais da saúde que treinaram assistentes não profissionais para fazer tarefas vistas como de domínio profissional da saúde. Esses treinamentos eram curtos e focados na educação e prevenção, mas também incluíam a instrução sobre medicamentos, primeiros socorros, doenças específicas e tratamentos simples. Essas iniciativas eram tentativas de treinar um amplo número de trabalhadores da saúde, rapidamente e com baixo custo, para cuidar de comunidades dificilmente atendidas pelos serviços de saúde.

Os TCS eram treinados por curtos períodos durante os quais thes era ensinado um número limitado de habilidades, mas no seu cotidiano eram solicitados a manejar os mais variados problemas e situações para as quais não estavam aptos, uma vez que 
frequentemente viviam em áreas remotas e o encaminhamento para outros serviços de saúde ou a supervisão por outros profissionais eram difíceis de garantir.

Walt e colaboradores (1990) analisaram alguns papéis comuns e contraditórios desempenhados pelos trabalhadores comunitários:

- Minidoctors: os TCS conseguiam maior credibilidade das comunidades quando eram capazes de tratar doenças e ofertarem medicamentos. Entretanto, os sistemas de saúde eram muito relutantes em permitir que os TCS tivessem acesso a essas técnicas, como uso de antibióticos e injeções.

- Um par extra de mãos: quando os TCS estavam ligados a um serviço de saúde, os profissionais de enfermagem tendiam a percebê-los como ajuda extra para dividir a carga de trabalho assistencial, executando tarefas que não desejavam realizar. Os TCS também tendiam a preferir trabalhar nos serviços de saúde ao lado de outro profissional do que realizar visitas domiciliares e atividades educativas.

- Educadores: a prioridade da atuação dos TCS deveria ser a atividade educativa, entretanto as evidências mostraram ser frequentes as ações voltadas para procedimentos. Os autores discutem que, além das dificuldades inerentes às tentativas de mudar o comportamento das pessoas e de atuar em problemas multifatoriais, é problemático manter o interesse da comunidade num conjunto limitado de atividades de educação, além da falta de incentivo e recursos para desenvolvê-las nos sistemas de saúde.

- Ligação: frequentemente esperava-se que os TCS respondessem ou consultassem comitês comunitários de saúde, organizações comunitárias e mantivessem laços próximos com cuidadores tradicionais e parteiras. Associa-se esse papel a uma expectativa de que eles efetuassem ligação entre os serviços, os profissionais e as comunidades, mas, por se identificarem mais com os profissionais da saúde, mesmo mantendo os vínculos comunitários, os TCS não exerceriam essa ligação com os terapeutas tradicionais.

Esses papéis eram influenciados pelos sistemas de saúde ao qual os TCS estavam vinculados, mas os autores observaram que os trabalhadores comunitários não eram muito ativos, a não ser que houvesse supervisão e estímulo constante. Em geral, os moradores das comunidades atendidas pelos TCS ficavam desapontados com o baixo número de atividade curativas que estes executavam, e os TCS, por sua vez, se sentiam inadequados e frustrados por não cumprirem essas expectativas. Naquele período havia poucos estudos sobre a qualidade e impacto em saúde do trabalho dos TCS. 
O outro desafio para o trabalho dos TCS se relacionava ao fato de que eles tinham o foco do seu trabalho no indivíduo e não na comunidade; eles aprendiam habilidades preventivas focadas em comportamentos individuais. Esse enfoque individual da doença é clássico no pensamento da saúde e ajuda a estruturar a formação e os serviços de saúde, mas limita a atenção dada a variáveis ambientais, sociais, culturais e econômicas que influenciam o comportamento das pessoas.

As experiências analisadas por Walt e colaboradores (1990) sugerem que os TCS não conseguiam suprir o vão entre comunidade e profissionais de APS, pois tendiam a se identificar com os profissionais e se tornavam o mais baixo nível da hierarquia profissional. Walt e colaboradores (1990) recomendam que para a qualidade de seu trabalho, os TCS precisam de treinamento sólido, educação continuada, suporte contínuo de medicamentos e apoio e supervisão constantes.

Veremos a seguir que, no contexto brasileiro, muitas dessas características e desafios se repetiram na trajetória dos ACS e dos AIS. Esse perfil de TCS foi também implementado no Brasil; por meio da ESF, a expansão da APS incorporou de forma consistente no SUS cerca de 260 mil ACS, que incialmente tinham como requisitos de trabalho saber ler e escrever, disponibilidade de tempo e espírito de solidariedade e liderança. Desde o fim dos anos 1990, ocorreu uma intensa mobilização política pela regulamentação profissional dos ACS, com o reconhecimento da profissão e aprovação de um referencial nacional de formação técnica para os ACS.

\section{Trabalhadores comunitários no Brasil e a regulamentação profissional dos ACS}

O marco para a expansão e incorporação no SUS dos TCS ocorre a partir de I991, com o Programa de Agentes Comunitários de Saúde (Pacs), e, em I 994, com o Programa Saúde da Família (PSF), atual ESF. Nesse momento, o ACS passa ser considerado como estratégico para a mudança do modelo de atenção e se transforma no maior quantitativo de trabalhadores responsáveis pela expansão dos serviços, atualmente estimados em mais de 260 mil.

O processo de trabalho e de formação dos ACS é perpassado por diversas disputas. Uma das questões colocadas se refere ao contexto de redução do papel do Estado, que tenciona a limitação da APS a um conjunto de ações e serviços, em contraposição à compreensão da APS como porta de entrada do sistema, com garantia de acesso integral à saúde (Morosini, Corbo $\varepsilon$ Guimarães, 2007). Outra questão importante se relaciona ao contexto de precarização dos vínculos de trabalho. 
Desde o começo da implantação do Pacs e do PSF, consolidou-se a ideia de que o ACS seria um mediador entre a comunidade e os serviços de saúde, principalmente com o objetivo de levar informações biomédicas para a população e subsidiar os demais profissionais com dados do contexto sociocultural e familiar. Nessa construção do papel social do ACS, perpassa a noção de que, por pertencer ao mesmo contexto sociocultural, teria a capacidade natural de interagir em estilo e linguagem mais efetivos, garantindo melhores resultados das ações de saúde, perspectiva da qual somos críticos. A defesa e normalização dessa perspectiva serviram de justificativa para que, de 1991 até 2002, os critérios para seleção de ACS se limitassem a: ser maior de 18 anos, saber ler e escrever, ter disponibilidade de tempo e capacidade de liderança e solidariedade. Segundo Morosini, Corbo e Guimarães (2007: 267),

A (não) escolarização dos ACS, justificada pela necessidade de esse trabalhador ser representativo da comunidade em que atua, denota a desvalorização da dimensão conceitual de sua qualificação, o que fortalece a desvalorização social desse trabalhador, sustenta a sua baixa remuneração e contrapõe-se à pauta política por uma melhor qualificação dos trabalhadores de saúde, de uma maneira geral.

Outro marcador da desvalorização desses trabalhadores é dado pelos seus recorrentes relatos de desvio de função, denotando a ideia de que o trabalho do ACS é "inespecífico e de baixa complexidade, podendo ser redirecionado, segundo as necessidades dos serviços, para atividades que supostamente exigem pouca capacitação" (Morosini, Corbo \& Guimarães, 2007: 267).

A primeira diretriz para trabalho dos ACS foi a portaria n. 1.886, em 1997, que caracteriza sua atuação como centrada na promoção da saúde e na prevenção de doenças; ademais vedava ao ACS o trabalho interno nas unidades de saúde. Segundo Morosini, Corbo e Guimarães (2007), entre 1998 e 1999 foram apresentados três projetos de lei para regulamentar o trabalho do ACS, e o decreto n. 3.189, de outubro de 1999, fixou as diretrizes para exercício da atividade dos ACS: "cabe ao Agente Comunitário de Saúde (ACS) (...) desenvolver atividades de prevenção de doenças e promoção da saúde, por meio de ações educativas individuais e coletivas, nos domicílios e na comunidade, sob supervisão competente".

Em razão da consistente atuação do movimento dos ACS, em 2002 aprovou-se a lei n. 10.507, que os reconhece como profissionais do SUS para o "desenvolvimento ações de promoção da saúde e prevenção das doenças por meio de processos educativos em saúde, privilegiando o acesso às ações e serviços de informação e promoção social e de proteção e desenvolvimento da cidadania, no âmbito social e da saúde" (Brasil, 2004: 17). Também se determinou com essa lei que os ACS a partir daquele momento 
deveriam ter o ensino fundamental completo. A continuidade e profundidade do debate desencadeado nesse período estabeleceram a convicção de que esse trabalhador desenvolvia um trabalho complexo e que sua formação não deveria se limitar a uma qualificação inicial (Morosini, Corbo \& Guimarães, 2007). Assim, em 2004, foi discutido e aprovado o Referencial Curricular para Curso Técnico de Agente Comunitário de Saúde (Brasil, 2004), que propôs um itinerário formativo que articulasse elevação da escolaridade e profissionalização de nível técnico em saúde e estabelecesse seis competências para a formação dos ACS:

I) Desenvolver ações que busquem a integração entre as equipes de saúde e a população adstrita à unidade básica de saúde, considerando as características e as finalidades do trabalho de acompanhamento de indivíduos e grupos sociais ou coletividades.

2) Realizar, em conjunto com a equipe, atividades de planejamento e avaliação das ações de saúde no âmbito de adstrição da unidade básica de saúde.

3) Desenvolver ações de promoção social e de proteção e desenvolvimento da cidadania no âmbito social e da saúde.

4) Desenvolver, em equipe, ações de promoção da saúde visando à melhoria da qualidade de vida da população, à gestão social das políticas públicas de saúde e ao exercício do controle da sociedade sobre o setor da saúde.

5) Desenvolver ações de prevenção e monitoramento dirigidas a grupos específicos e a doenças prevalentes, conforme definido no plano de ação da equipe de saúde e nos protocolos de saúde pública.

6) Desenvolver ações de prevenção e monitoramento dirigidas às situações de risco ambiental e sanitário para a população, conforme plano de ação da equipe de saúde (Brasil, 2004).

Em 2006, no intuito de avançar a desprecarização do trabalho dos ACS, os requisitos para exercício da atividade de ACS e seu processo de contratação foram revistos na lei n. II.350. Em termos de atribuições do trabalho das equipes de Saúde da Família, o documento mais recente se encontra na portaria n. 2.436, de 21 de setembro de 2017, que aprova a Política Nacional de Atenção Básica (Pnab), estabelece a revisão de diretrizes e normas para a organização da atenção básica, para a ESF e o Pacs. Como atribuições específicas dos ACS:

I-Trabalhar com adscrição de indivíduos e famílias em base geográfica definida e cadastrar todas as pessoas de sua área, mantendo os dados atualizados no sistema de informação 
da atenção básica vigente, utilizando-os de forma sistemática, com apoio da equipe, para a análise da situação de saúde, considerando as características sociais, econômicas, culturais, demográficas e epidemiológicas do território, e priorizando as situações a serem acompanhadas no planejamento local;

II - Utilizar instrumentos para a coleta de informações que apoiem no diagnóstico demográfico e sociocultural da comunidade;

III - Registrar, para fins de planejamento e acompanhamento das ações de saúde, os dados de nascimentos, óbitos, doenças e outros agravos à saúde, garantido o sigilo ético;

IV - Desenvolver ações que busquem a integração entre a equipe de saúde e a população adscrita à UBS, considerando as características e as finalidades do trabalho de acompanhamento de indivíduos e grupos sociais ou coletividades;

V - Informar os usuários sobre as datas e horários de consultas e exames agendados;

$\mathrm{VI}$ - Participar dos processos de regulação a partir da atenção básica para acompanhamento das necessidades dos usuários no que diz respeito a agendamentos ou desistências de consultas e exames solicitados;

VII - Exercer outras atribuições que Ihes sejam atribuídas por legislação específica da categoria, ou outra normativa instituída pelo gestor federal, municipal ou do Distrito Federal. (Brasil, 2017)

Se no cenário urbano do trabalho e formação do ACS existem esses diversos desafios, no contexto indígena veremos que se agregam outras questões e complexidades, que iremos abordar a seguir.

\section{A estruturação da APS para os povos indígenas e os AIS}

No Brasil realizou-se, em 1986, a I a Conferência para Proteção à Saúde dos Povos Indígenas, que iniciou a primeira formulação de uma política pública nacional de atenção à saúde dos povos indígenas. Historicamente, apenas ações pontuais e emergenciais de saúde eram ofertadas aos povos indígenas, o que entre outros fatores (como o avanço em seus territórios) gerou um quadro sanitário alarmante nessa população.

Durante a década de 1980, em razão da dificuldade de acesso aos serviços de saúde e baixa permanência das equipes de saúde da Fundação Nacional de Saúde (Funasa) e do Ministério da Saúde (MS) nas aldeias, universidades e organizações não governamentais realizaram projetos de formação e capacitação de índios para desenvolverem ações de saúde nas comunidades. Essas experiências criaram a figura do AIS, que seria um membro da comunidade, indicado por ela para desenvolver ações de saúde. 
A Constituição de 1988 foi um marco na mudança da relação do Estado com os povos indígenas brasileiros, pois assegura aos índios sua organização social, costumes, línguas, crenças e tradições, e reconhece a demarcação e usufruto exclusivo de seus territórios. No âmbito das políticas sociais, as lutas dos povos indígenas no Brasil possibilitaram a implantação de um sistema público específico de atenção à saúde dos povos indígenas integrado ao SUS. A criação de um subsistema - único dessa natureza entre os produtos advindos da Reforma Sanitária - expressa o reconhecimento, pelo legislador, das limitações de uma política universalizante como a do SUS, diante das especificidades e necessidades das minorias indígenas. Buscava-se, assim, garantir tanto o direito ao acesso universal aos serviços de saúde, equalizando o índio aos outros cidadãos brasileiros, quanto o cuidado culturalmente específico e sensível às necessidades locais das múltiplas etnias atendidas pelo subsistema (Subsistema de Atenção à Saúde Indígena - Sasi/SUS).

Entretanto, existem diversos limites e dificuldades para a plena implementação de uma atenção à saúde de qualidade e que respeite as especificidades socioculturais dos povos indígenas, tais como a insatisfação dos indígenas, a baixa resolutividade, e as inadequações culturais do subsistema.

A Política Nacional de Atenção à Saúde dos Povos Indígenas (Pnaspi) (Brasil, 2002) procurou assegurar o acesso à atenção integral à saúde, organizada sob a forma de DSEI, sob responsabilidade de um gestor federal, que inicialmente foi a Funasa/MS e, desde 2010 , é a Secretaria Especial de Saúde Indígena (Sesai/MS).

O modelo de atenção proposto se baseia numa rede interiorizada de atenção básica articulada com o restante da rede de serviços de saúde do SUS, para garantir assistência de média e alta complexidade. A estrutura do DSEI compreende os postos de saúde nas aldeias, onde atuam os AIS; os polos-base, primeiro nível de referência para os postos de saúde, com equipes multidisciplinares compostas de médicos, enfermeiros e técnicos de enfermagem; e a Casa de Saúde do Índio (Casai), que apoia as atividades de referência para o atendimento de média e alta complexidade nos demais serviços da rede do SUS. Dessa forma, a organização do distrito prevê diferentes níveis de resolutividade e se articula com o restante da rede SUS quando se faz necessária a realização de exames, de consultas com especialistas, de internações ou de procedimentos invasivos. Com a implementação dos DSEls, desde 1999, os AIS foram incorporados formalmente nas equipes multiprofissionais de saúde indígena (Emsi).

A Pnaspi frisa a importância da sensibilidade cultural no desenvolvimento das ações de saúde nos DSEls, tendo optado pelo termo atenção diferenciada para expressá-la. 
Em que pese a importância da atenção diferenciada na política de saúde dirigida às minorias indígenas, não há, no texto da Pnaspi, uma caracterização precisa de seu sentido nem indicação de formas concretas que essa diferenciação poderia assumir nas práticas sanitárias cotidianamente desenvolvidas nos DSEls.

A temática da atenção diferenciada e da articulação entre saberes científicos e tradicionais indígenas guarda interfaces com atributos da APS, na medida em que implica o reconhecimento e a construção das ações locais em articulação com as singularidades étnico-culturais e a diversidade nos modos de interpretar a doença, produzir estratégias de cura e cuidados e de mobilizar redes sociais e familiares para lidar com tais eventos. Nesse contexto, o AIS, na condição de membro indígena da equipe de saúde, desponta como elemento-chave, e essa é uma das dimensões principais com a qual pretendemos contribuir, demonstrando algumas estratégias e experiências desenvolvidas no curso técnico para AIS que podem ser adaptadas e utilizadas em outros contextos.

\section{Ambiguidades e indefinições na construção do papel do AIS}

Existem poucos dados sobre as características dos trabalhadores AIS no Brasil. Sabemos que seu quantitativo vem aumentando: em 1998, eram 1.400; e em 2004 já eram 3.665 (Brasil, 2005). Com base em informações provindas de reuniões com a Sesai, estimamos que atualmente sejam ao redor de seis mil AIS e Agentes Indígenas de Saneamento (Aisan) contratados nos 34 DSEls existentes no Brasil.

Os AIS são os principais responsáveis pela regularidade do acesso a ações e serviços de saúde para cerca de 700 mil pessoas atendidas pelo subsistema de saúde indígena brasileiro. Esse subsistema foi criado em 1999, por meio da Lei Arouca (lei n. 9.836/99) que instituiu o Sasi e definiu que a organização da atenção à saúde se daria por redes territorializadas de saúde, na forma de 34 DSEls.

Ao revisarmos a trajetória e pesquisas sobre os AIS no Brasil, observamos vários pontos de convergência com a análise de Walt e colaboradores (1990). Nas revisões (Diehl, Langdon \& Dias-Scopel, 2012), aponta-se que, em geral, os AIS não possuem formação prévia e nenhuma exigência de escolaridade para iniciar seu trabalho (esse último aspecto tem mudado mais recentemente). Na literatura, os processos formativos nos distritos foram descritos como irregulares, intermitentes, sem certificação ou articulação com o processo de escolarização. A falta de formação e qualificação aparece como um agravante na relação com a equipe multidisciplinar, que o entende como um profissional não técnico e desqualificado. Assim, os AIS demandam e buscam individualmente acesso a conhecimentos em saúde. 
Os AIS têm diferentes perfis de atuação em cada região e DSEI, mas identificamos uma forte tendência na aplicação e distribuição de tecnologias biomédicas. Diehl, Langdon e Dias-Scopel (2012) avaliam que, nos contextos indígenas mais isolados, os AIS desempenham um papel mais claro na assistência e que, nos distritos com contato regular com os demais profissionais da equipe multiprofissional, as atribuições dos AIS são ainda menos definidas.

Encontramos no trabalho do AIS um conflito de expectativas e interesses. Para os enfermeiros e técnicos de enfermagem, os agentes não deveriam executar as ações técnicas, mas tão somente o preenchimento de fichas, distribuição de medicamento e atividades de comunicação. Entretanto, a expectativa das comunidades seria de que os agentes executassem ações biomédicas. Discute-se o papel de articulação/vinculação/ mediação entre os serviços de saúde e as práticas tradicionais como uma atribuição do AIS, mas aponta-se que essa função não é plenamente desenvolvida.

Todas essas pesquisas indicam que a implantação de um subsistema de saúde específico para os povos indígenas, com a inclusão de membros indígenas nas equipes, os próprios AIS, não garantiu o acesso a uma atenção à saúde de qualidade nem o protagonismo indígena desejado no campo da saúde indígena. Adiciona-se a isso o fato de que algumas lideranças indígenas apontam claramente que a implementação do subsistema de saúde indígena, ao invés de fortalecer o papel dos AIS (que já atuavam como voluntários há vários anos), fez com que eles perdessem autonomia e recursos para resolução dos problemas das comunidades.

Não obstante, os AIS representam uma melhoria de acesso aos serviços de saúde para os indígenas acompanhados. No modelo proposto no subsistema de saúde indígena, o AIS é central para a efetivação, no cotidiano, da atenção. Em razão da alta rotatividade dos profissionais não indígenas (Diehl, Langdon $E$ Dias-Scopel, 20I2), em muitos distritos somente o AIS está atuando regularmente nas comunidades, principalmente nas mais isoladas. Portanto, em termos de ampliação de acesso, eles são fundamentais. Ademais, a perspectiva de construção da atenção diferenciada, dimensão relativa à especificidade e à diversidade sociocultural dos povos indígenas, está fortemente baseada na ação do AIS (Diehl, Langdon \& Dias-Scopel, 2012).

Em 2012, a Sesai realizou um levantamento com as coordenações locais dos 34 DSEls para realizar um diagnóstico do perfil dos AIS no Brasil, cujos resultados foram divulgados em reunião. A secretaria obteve resposta de 3 I distritos, e como perfil dos AIS naquele momento observaram-se: 
- 33\% dos AIS são do sexo feminino e 67\% do sexo masculino;

- Em relação à faixa etária: $11 \%$ com idade entre 18 e 25 anos, 19\% entre 25 e 30 anos, 22\% entre 30 e 35 anos, $19 \%$ entre 35 e 40 anos e $28 \%$ maiores de 40 anos;

- Em relação ao idioma, 7\% não falavam português;

- $88 \%$ têm alguma escolaridade e, desses, $46 \%$ têm ensino fundamental completo e $30 \%$ ensino médio, e $1 \%$ ensino superior;

- 55\% mencionaram realizar um curso introdutório dos AIS;

O dado que mais se destaca é a aparente tendência de elevação da escolaridade dos agentes, o que indica um contexto positivo para a profissionalização em nível técnico desses trabalhadores.

Em termos legais, até 2010 , a Funasa/MS era a responsável pelo Sasi. Em dezembro de 2010 , foi criada a Sesai no MS, que assumiu essa responsabilidade, mas que, somente em 2017, apresentou novas diretrizes para a formação de AlS e Aisan.

Dessa forma, os documentos nos quais pudemos nos basear para discussão da regulamentação profissional dos AIS ainda eram do período da Funasa. A Funasa (Brasil, 2005) apontava como papel do AIS:

- acompanhamento de crescimento e desenvolvimento;

- acompanhamento de gestantes;

- atendimento aos casos de doenças mais frequentes (infecção respiratória, diarreia, malária);

- acompanhamento de pacientes crônicos;

- primeiros socorros;

- promoção da saúde e prevenção de doenças de maior prevalência;

- acompanhamento da vacinação; e

- acompanhamento e supervisão de tratamentos de longa duração.

Essas atribuições são genéricas e inespecíficas e não demonstram consideração ao contexto indígena. Em razão da falta de clareza quanto ao papel e atribuições do AIS, os diversos DSEls por vezes apresentam alguma regulamentação própria. Assim, encontramos nas diversas regiões diferentes perfis profissionais dos AIS.

$\mathrm{Na}$ falta de uma regulamentação específica, considerando o contexto histórico e inserção na atenção básica dos AIS, optamos pela utilização de documentos e 
regulamentações propostas para os ACS, em razão das semelhanças históricas e de construção do papel social desses trabalhadores.

Durante a implementação da proposta formativa, houve reuniões regulares da equipe de coordenação do curso com as lideranças indígenas e com a equipe de profissionais e gestores do DSEl do Alto Rio Negro. Com base nessas conversas, percebemos a necessidade de que o desenvolvimento curricular permitisse a melhor definição do papel dos AIS nas equipes e comunidades, com detalhamento das técnicas e atividades a serem desenvolvidas em cada área de atuação. Assim, durante a implementação curricular do CTACIS, podemos identificar um conjunto de atribuições que, de acordo com a coordenação do curso, os técnicos em agente comunitário indígena de saúde poderiam desenvolver, em conjunto e sob supervisão da equipe multidisciplinar de saúde indígena, conforme o perfil e necessidade de cada comunidade. 


\section{2}

\section{Concepções político-pedagógicas, interculturalidade e organização curricular do Curso Técnico de Agentes Comunitários Indígenas de Saúde}

\section{Contexto e histórico da experiência}

A região do Alto Rio Negro se localiza no noroeste amazônico, na tríplice fronteira Brasil-Colômbia-Venezuela, onde vive uma população indígena estimada em 38.000 pessoas, de cerca de vinte etnias, distribuídas em mais de oitocentos assentamentos, dispersos em 12.000 hectares de terras indígenas demarcadas. Esses grupos étnicos enfrentam uma situação de alta vulnerabilidade social e sanitária, expressa pela dificuldade de acesso aos recursos alimentares, por altas taxas de natalidade e de mortalidade infantil e por um perfil epidemiológico com elevada frequência de doenças transmissíveis, que coexistem com uma precária interiorização das políticas públicas nas aldeias.

Essa região é uma bacia hidrográfica drenada pelo Alto e Médio rio Negro, e seus afluentes, como os rios Ulaupés, Içana, Xié, entre outros inúmeros rios e igarapés. A maior parte desse território é da União, constituída por terras indígenas, reconhecidas entre 1995 e 1996, e duas Unidades de Conservação, uma federal (Parque Nacional Pico da Neblina) e outra estadual (Reserva Biológica Morro dos Seis Lagos). É uma região povoada há pelo menos três mil anos por vários povos indígenas, atualmente, ali vivem mais de vinte povos falantes de idiomas de três troncos linguísticos, arawak, tukano e maku, que historicamente estabelecem relações de intercâmbios e trocas, e processos de migrações.

Nessa região, no final da década de 1980, uma intensa mobilização dos diferentes povos indígenas pela demarcação das terras indígenas levou à criação de uma das primeiras organizações indígenas no Brasil: FOIRN. Essa entidade conta com cerca de quarenta associações de base filiadas, pertencentes aos diferentes grupos étnicos da região, e ao longo dos anos vem desenvolvendo diferentes projetos de desenvolvimento sustentável, educação, saúde, entre outros temas. 
Em 2000, a partir da promulgação da lei n. 9.836, foi criado na região o Distrito Sanitário Especial Indígena do Alto Rio Negro (DSEIRN), para atender as populações residentes nos territórios indígenas dos municípios de São Gabriel da Cachoeira, Santa Isabel do Rio Negro e Barcelos, no estado do Amazonas. Com o DSEIRN, os AIS que vinham atuando como voluntários na região desde a década de 1980 foram contratados para as equipes multidisciplinares de saúde indígena. Também se instituiu no DSEIRN o Conselho Distrital de Saúde Indígena do Alto Rio Negro (Condisi-RN), órgão paritário de controle social responsável pelo acompanhamento da implementação das ações na região.

O projeto-piloto de profissionalização em saúde, articulado com a elevação da escolaridade de 189 AIS que atuavam no DSEIRN, foi iniciado com base na demanda do movimento indígena da região do Alto Rio Negro e do controle social do DSEIRN. Em 2007, a FOIRN levou como pauta para o Condisi-RN a reflexão sobre a atuação e qualificação dos I 96 AIS que atuavam na região, identificando diferentes vínculos, níveis de escolaridade, irregularidade e falta de qualificação profissional e baixa resolutividade de sua atuação nas comunidades. Diante desse quadro, o Condisi-RN definiu que no prazo de cinco anos os AIS da região deveriam ter a escolaridade elevada para nível médio e uma profissionalização técnica na área da saúde, com melhor definição de sua atuação.

Assim, quando as lideranças indígenas do Rio Negro solicitaram a parceria da Fiocruz para a formação profissional dos AIS do DSEIRN, foram enfáticos quanto a algumas exigências para o desenvolvimento do projeto. A demanda era que o processo fosse reconhecido e legitimado em todas as instâncias legais necessárias para que os AIS tivessem uma titulação reconhecida pelos sistemas educacionais brasileiros. Outra exigência era a de que se desenvolvesse a formação profissional de forma concomitante à elevação da escolaridade até o nível médio. Por fim, solicitava-se a construção de uma proposta curricular de profissionalização em saúde específica e diferenciada para o contexto indígena.

Para subsidiar a construção da proposta, em outubro de 2007 realizou-se na cidade de São Gabriel da Cachoeira, o I Seminário para Formação Profissional dos Agentes Indígenas de Saúde Alto Rio Negro. Nesse evento, reuniram-se representantes dos AIS, professores e diretores de escolas indígenas da região, e diversas lideranças indígenas da FOIRN, com profissionais da saúde e gestores do DSEIRN, representantes da Semec, da Semsa, Seduc/Deppe/Geei, e pesquisadores do ILMD/Fiocruz e EPSJV/Fiocruz.

As discussões do evento foram fundamentais, pois nele realizou-se um diagnóstico da situação formativa e da atuação dos AIS nas comunidades. Com relação ao primeiro ponto, identificou-se a descontinuidade no processo de qualificação dos AIS na região, 
além de desigualdades no nível de escolarização e desmobilização política dos AIS. Esse panorama destoava dos avanços na formação dos professores indígenas na região que já estavam em nível de graduação e pós-graduação e tinham um protagonismo político quanto às pautas da educação.

Do ponto de vista da atuação dos AIS nas comunidades, verificou-se que o perfil de atividades desenvolvidas se restringia à execução dos chamados serviços gerais (limpeza da unidade, responder à radiofonia, carregar caixas com material de atendimento etc.), à atuação como tradutores improvisados quando pacientes indígenas não compreendiam o português e ao fornecimento de alguns medicamentos (principalmente antitérmicos e vermífugos), desenvolvendo poucas ações de promoção da saúde, de participação social e de preservação da cultura tradicional indígena. Essa situação foi considerada muito grave, pois diante da alta rotatividade e irregularidade da atuação dos demais profissionais da saúde do subsistema de saúde indígena, os AIS eram os únicos membros das equipes multidisciplinares de saúde indígena a atuarem de forma contínua nas comunidades.

Ademais, como membros das comunidades, os AIS eram quem melhor poderiam subsidiar as equipes com informações acerca das condições de vida e situação de saúde da população. Entretanto, a falta de escolaridade e de profissionalização era usada como justificativa pelos demais profissionais da saúde para desconsiderá-los como sujeitos relevantes para a organização e implementação das ações de saúde.

Nesse evento também foram criticadas iniciativas anteriores de formação dos AIS na região porque desconsideravam os conhecimentos, práticas e especialistas em saúde das comunidades indígenas. Na tradição dos povos indígenas existem conhecimentos sobre o processo saúde-doença, meios de prevenção e tratamento das doenças que deveriam ser reconhecidos e valorizados na formação dos AIS, mas em geral eram desconsiderados ou desvalorizados nesses processos formativos. Os participantes também apontaram a necessidade de valorização dos conhecedores de práticas tradicionais de saúde da região (pajé, benzedores, conhecedores de plantas etc).

Como recomendações gerais para o processo formativo levantadas nesse momento, destacamos: valorização e intensificação do uso da medicina tradicional; direcinamento para a prevenção de doenças e para a promoção da saúde e de ambientes saudáveis; potencialização da parceria entre escolas e sistema de saúde; estímulo às lutas políticas em parceria com associações indígenas e outros fóruns de lutas pelos direitos à diferença étnica; valorização da oralidade e da escrita das línguas indígenas nas aulas; viabilização da publicação de material educativo em línguas indígenas; facilitação da aquisição de conhecimentos gerais e específicos da área da saúde; e viabilização do acesso a conhecimentos técnicos na área da saúde. 
Durante o I Seminário para Formação Profissional dos Agentes Indígenas de Saúde do Alto Rio Negro também foram discutidos aspectos metodológicos do processo formativo ressaltando-se o ensino por meio da pesquisa, preconizado na educação escolar indígena como estratégia educativa prioritária para a sistematização do conhecimento local; a produção de material didático específico; e o desenvolvimento de estratégias que auxiliassem as comunidades no enfrentamento de seus principais problemas de saúde. Tratou-se, em suma, de definir, a partir do ponto de vista e necessidades locais, o leque de atribuições profissionais dos AIS, mas sem descurar dos princípios da APS e da educação escolar indígena, que recomenda a interculturalidade como princípio políticopedagógico orientador dos processos formadores.

A partir do I Seminário, um grupo formado por pesquisadores da área da saúde indígena, antropólogos, especialistas em educação indígena e educação profissional em saúde e lideranças indígenas elaborou o Plano de CTACIS. A proposta foi apresentada, discutida e aprovada na Assembleia da Associação dos AIS do Alto do Rio Negro (AAISARN), em março de 2008, na qual se reuniu quase a totalidade dos AIS que atuavam no DSEIRN.

É importante destacar que a reivindicação de elevação da escolaridade e profissionalização dos AIS tem sido recorrente desde a I Conferência Nacional de Proteção da Saúde do Povos Indígenas, realizada em 1986, sendo ponto de pauta também nas subsequentes Conferências Nacionais de Saúde Indígena ocorridas em 1993, 200I, 2006 e 2013. Porém, os gestores federais da saúde indígena, inicialmente a Funasa e atualmente a Sesai, têm avançado pouco nesse debate e na implementação de propostas formativas. Ademais, até o momento, não existe um reconhecimento profissional da categoria de AIS e faltam regulamentações sobre suas atribuições e atuação nas equipes de saúde. Como repercussões desse cenário, tem-se, por exemplo, a percepção das lideranças comunitárias do Rio Negro de que a implementação do subsistema, a partir de 2000, ao invés de fortalecer a atuação dos AIS, tem enfraquecido seu protagonismo, retirando progressivamente sua autonomia no desenvolvimento de ações de saúde, justamente por não serem considerados profissionais da saúde.

Existe um avanço importante no debate nacional sobre educação no âmbito do movimento indígena. Os povos indígenas têm exigido o acesso aos diferentes níveis de escolaridade, vistos como estratégicos para fortalecimento do diálogo com a sociedade nacional, para maior protagonismo nas políticas indigenistas e para a autonomia dos seus territórios. Consideramos que os atores envolvidos com a saúde indígena têm pouca proximidade com as pautas e reflexões mais gerais do movimento indígena e das políticas indigenistas, de modo que existe um descompasso entre os campos da 
educação e da saúde indígena. Na construção do projeto político-pedagógico da proposta formativa dos AIS, procuramos fazer essa aproximação e diálogo, e consideramos que essa é uma contribuição importante da experiência do CTACIS. Por isso, iniciamos esse capítulo com uma breve revisão da educação escolar indígena e sua importância para a construção de uma concepção crítica de interculturalidade, tomada como eixo do projeto político-pedagógico do CTACIS.

\section{Educação escolar indígena e a perspectiva crítica de interculturalidade}

O conceito de interculturalidade começa a ser construído na década de 1970, e está intimamente relacionado com o desenvolvimento da educação escolar indígena na América Latina. Candau (2013) destaca que as trajetórias de educação escolar indígena nos diferentes países passaram, de forma geral, por quatro etapas que são importantes para entendermos o desenvolvimento das discussões acerca da interculturalidade.

A primeira etapa ocorre do período colonial até as primeiras décadas do século $X X$, quando, ainda fundamentadas numa visão etnocêntrica e colonialista, as práticas educativas voltadas para os indígenas tinham como principal objetivo sua assimilação e homogeneização nas sociedades nacionais.

Na segunda etapa surgiram as primeiras escolas bilíngues, momento em que as línguas indígenas adentraram o espaço escolar; o bilinguismo era visto como estratégia para melhor alfabetizar e "civilizar" os indígenas (Candau, 2013). Nesse período, no Brasil, as escolas indígenas contavam com auxiliares indígenas que serviam para, por meio da tradução, facilitar o aprendizado do português e dos conhecimentos e valores da sociedade nacional. Esse foi o denominado bilinguismo de transição, com o intuito de que as crianças abandonassem suas línguas maternas para assim promover uma homogeneização cultural e assegurar os objetivos civilizatórios do Estado.

A partir da década de 1970, temos a terceira etapa, quando se identificam experiências alternativas protagonizadas por lideranças indígenas em parceria com universidades, igrejas e organizações não governamentais, nas quais se produziram materiais didáticos e programas educativos que buscavam fortalecer e valorizar as culturas e línguas indígenas. O bilinguismo deixa de ser visto como instrumento civilizatório e passa a ser um componente de valorização cultural dos povos indígenas.

Nesse período, passa-se a discutir que a perspectiva intercultural está relacionada com a crítica ao modelo escolar e com a percepção da "intrínseca relação entre proces- 
sos educativos e os contextos socioculturais em que estes estão situados, colocando assim no centro das ações pedagógicas os universos culturais dos atores implicados" (Candau, 2013: 149). Com base nesses novos paradigmas, visava-se a uma nova relação com a sociedade nacional e órgãos indigenistas, com maior autonomia e igualdade. A educação indígena passou a ser uma das principais pautas do movimento indígena, que também reivindicava a organização e gestão dessas escolas pelas próprias comunidades indígenas. Assim, propostas curriculares diferenciadas e materiais didáticos específicos foram produzidos, e iniciaram-se encontros e reuniões entre pessoas envolvidas com experiências alternativas de educação indígena, no Brasil e em diversos países da América Latina.

A quarta etapa da educação intercultural se desenvolve a partir das décadas de 1980 e 1990, quando a luta dos povos indígenas logra, em diferentes países na América Latina, o reconhecimento constitucional do caráter multiétnico de suas sociedades e a consolidação de direitos sociais, culturais e territoriais indígenas. No Brasil, a Constituição Federal (CF) de 1988 reconheceu o direito dos povos indígenas às suas terras e aos seus modos de vida, com suas especificidades e diversidades culturais e linguísticas, garantindo-lhes o direito de preservar sua organização social, costumes, línguas, crenças e tradições (CF, artigo 23l). No âmbito da educação, é assegurada às comunidades indígenas a utilização de suas línguas maternas e processos próprios de aprendizagem (CF, artigo 210$)$.

Esse novo contexto permitiu a construção de políticas públicas que contemplassem as diferenças culturais e provocou mudanças na área de educação indígena, que passou a ser reivindicada pelas comunidades como forma de construção de novos projetos de futuro e novas formas de relação com o restante da sociedade brasileira.

Nas últimas décadas vivemos um período de intensa reflexão crítica acerca do conceito de interculturalidade, que passa a transcender o âmbito específico da educação escolar indígena, provocando reflexões acerca da possibilidade de transformação do conjunto dos sistemas educacionais e da sociedade no sentido da construção de relações mais democráticas entre os diferentes grupos étnicos e culturais na sociedade.

Pensar a interculturalidade de forma crítica pressupõe muito mais do que somente reconhecimento e valorização da diversidade étnico-cultural. Tais discussões envolvem o questionamento das desigualdades e assimetrias construídas historicamente entre os diferentes grupos sociais (étnicos, de gênero, raciais, de orientação sexual, entre outros), implicando "assumir as diferenças como constitutivas da democracia e a construção de relações novas, verdadeiramente igualitárias entre os diferentes grupos socioculturais" (Candau, 2013: 152). 
Na atualidade temos a coexistência e tensão entre essas diferentes perspectivas de educação indígena e interculturalidade, mas é importante destacar que, historicamente, ainda trazemos uma forte herança das práticas e dos valores que foram construídos hegemonicamente ao longo da nossa história, que persistem em tentar assimilar os indígenas à cultural nacional.

Apesar dos processos assimilacionistas, os povos indígenas mantiveram suas identidades étnicas e desenvolveram estratégias de manutenção de suas diferenças. Ademais, o conhecimento tradicional tem sua especificidade de acordo com o grupo étnico, o que destaca o caráter local desse tipo de conhecimento. Entretanto, isso não exclui o intercâmbio de conhecimentos entre povos nem a dinamicidade desse conhecimento. O reconhecimento da mutabilidade histórica dos conhecimentos tradicionais é um aceno para a possibilidade de trocas entre culturas e reforça a capacidade desses povos de se adequarem às transformações e realidades do mundo atual.

\section{Profissionalização, intermedicalidade e atenção diferenciada}

Um dos desafios para a construção da proposta formativa do CTACIS foi articular as reflexões críticas do âmbito da educação escolar indígena com a profissionalização no campo da saúde.

O domínio de determinado conhecimento é um dos requisitos mais importantes para o reconhecimento da autoridade profissional, seja na perspectiva da sociologia das profissões, seja no senso comum. Agregamos a esse debate a perspectiva de que a educação profissional em saúde deve permitir ao trabalhador de nível médio a compreensão dos princípios científicos que estão na base do trabalho em saúde, não se limitando a uma capacitação para e no trabalho.

A denominada medicina científica é a base da formação profissional em saúde na sociedade ocidental e é a concepção hegemônica para a organização das práticas e dos serviços. Porém, nosso objetivo era construir uma proposta de profissionalização intercultural e, dessa forma, não deveria significar somente aquisição de conhecimento biomédico, inclusive porque o agente de saúde transita entre diversos campos profissionais. Adotar a biomedicina como conhecimento universal no campo da saúde significava reproduzir a perspectiva assimilacionista. Também entendemos o campo da saúde como um mercado simbólico, em que diferentes tradições e perspectivas sobre o processo saúde-doença-atenção estão em disputa, sendo a biomedicina uma delas. 
Dado o fato de que os diferentes sistemas médicos estão em relações de desigualdades e assimetrias de poder e que, na atualidade, a biomedicina é hegemônica, há que se perguntar como equilibrar, no âmbito do contato interétnico, uma assimetria que perpassa a própria estrutura social. Nesse contexto, vale relembrar que historicamente as práticas indígenas de saúde foram consideradas ilegítimas e ativamente ignoradas e desvalorizadas dentro e fora dos seus territórios indígenas.

Na formação dos AIS, os críticos têm apontado a predominância de uma orientação para as práticas e conhecimentos biomédicos, ignorando, e às vezes desrespeitando, as concepções e práticas indígenas. Para evitar ou limitar tal risco nos aproximamos de uma perspectiva antropológica dos modelos de atenção à saúde, articulando-a ao debate sobre a atenção diferenciada no subsistema de saúde indígena com o intuito de subsidiar a construção da proposta do CTACIS.

Menéndez (2003) ressalta que a maioria da população utiliza simultaneamente diversos sistemas médicos, tanto para diferentes problemas, quanto para um mesmo problema de saúde, o que o autor denomina de pluralismo médico. Entretanto, alerta que a perspectiva dos sistemas nacionais de saúde e da biomedicina, nega, ignora ou marginaliza essa diversidade, conforme apontado nas experiências formativas de AIS.

A hegemonia do modelo biomédico, hiperdimensionando a dimensão biológica do processo saúde-doença, se expressa também no uso de tecnologias no diagnóstico e na medicalização de diversos problemas de saúde e da vida em geral (Menéndez, 2003). Em certas circunstâncias, a biomedicina legitima cientificamente outros sistemas de saúde e os incorpora ao seu repertório nos serviços de saúde, como ocorreu com a acupuntura. Mas, ressalta o autor, em que pese tal processo de reconhecimento de outros sistemas médicos, apenas são legitimadas as dimensões biológicas que envolvem os procedimentos de cura e cuidados.

Ademais, o campo cultural é identificado por Menéndez (2003) como um dos mais excluídos da biomedicina. Quando a biomedicina se refere à dimensão cultural, frequentemente o faz com uma conotação negativa, apontando fatores culturais que favoreceriam o adoecimento ou gerariam resistência às práticas biomédicas. As equipes de saúde consideram que seu papel é mudar ou abolir os saberes populares, ou criar mecanismos administrativos ou médicos que promovam tal modificação, como o incentivo econômico.

Nesse contexto, a formação e a atuação dos AIS têm favorecido a difusão de noções de higiene, cujo caráter etnocêntrico tende a reforçar juízos negativos sobre as culturas indígenas. Nossa proposta formativa buscava romper com essas limitações, por isso 
adotamos a perspectiva crítica da interculturalidade em saúde, que denominaremos aqui de intermedicalidade.

O entendimento da intermedicalidade passa pelo reconhecimento de que o processo terapêutico é uma "sequência de decisões e negociações entre várias pessoas e grupos com interpretações divergentes a respeito da identificação da doença e da escolha da terapia adequada" (Langdon, 2005: 121). A intermedicalidade se refere, portanto, ao âmbito da negociação e dos usos feitos pelos sujeitos, em busca de cura, dos diferentes elementos e práticas da medicina tradicional, da biomedicina, autoatenção, entre outros. Do ponto de vista dos sujeitos, o campo da saúde é reconhecido como composto de diversas tradições que não se opõem, mas se reinterpretam, ressignificam e se apropriam mutuamente. Esse processo é influenciado pelos contextos locais e nacionais, tais como a história de contato, e pelas políticas públicas relacionadas com os povos indígenas.

Assim, relembra Langdon (2005), em contextos médicos plurais como são os territórios indígenas, torna-se fundamental reconhecer que há uma relação e negociação constante entre diferentes sistemas médicos e representações de saúde-doença, numa dinâmica que se expressa como intermedicalidade (Langdon, 2005). Na nossa abordagem procuramos enfatizar a proatividade indígena ao se relacionar com a sociedade nacional e com as distintas realidades sociomédicas, seguindo conclusões de Menéndez (2003), que demonstra uma ativa apropriação de estratégias e recursos terapêuticos da biomedicina por curadores tradicionais, parteiras e outros agentes populares de cura.

Na ausência de um conceito de atenção diferenciada nos documentos da política de saúde indígena capaz de orientar a atuação de profissionais no subsistema, recorremos à literatura para melhor caracterizar esse eixo estruturante da atuação em saúde indígena. Para Langdon (2004: 42) "atenção diferenciada é mais bem-conceituada não como incorporação de práticas tradicionais aos serviços de saúde primária, e sim como articulação entre estes e as práticas de autoatenção existentes na comunidade particular". Dessa forma, propomos articular o conceito de atenção diferenciada com o de autoatenção.

O conceito de autoatenção, desenvolvido por Menéndez (2003), envolve duas dimensões. A primeira se refere ao sentido amplo das práticas ligadas a "processos de reprodução biossocial" do grupo, envolvendo as relações com o território, a alimentação, as normas sociais, entre outros. Nesse sentido, percebemos importante conexão entre a ideia de atenção diferenciada e autoatenção, entendidas como integrantes da reprodução social, e as lutas do movimento indígena pela demarcação e defesa das terras indígenas, sintetizadas no lema "terra é saúde". A outra dimensão do conceito de autoatenção se refere propriamente às representações de doença, às práticas de prevenção e aos 
tratamentos utilizados pelos diferentes grupos sociais para enfrentamento dos problemas de saúde. No contexto indígena, essas representações e práticas se referem diretamente aos sistemas explicativos de doença e cura, fortemente impregnados pela cosmologia de cada grupo e pelos recursos terapêuticos disponíveis no acervo cultural de cada etnia.

Munidos de tal arsenal teórico fez-se possível converter essas amplas temáticas - via de regra designadas no campo da saúde coletiva como determinantes sociais e condições de vida - em tópicos da matriz curricular proposta para o curso, o que permitiu relativizar a biomedicina e, principalmente, ampliar a abordagem dos problemas de saúde para além da dimensão biológica; além de discutir e investigar as relações entre territórios/terras indígenas, socioambiente, cosmologia e outras dimensões culturais com interveniência na saúde em comunidades indígenas. Em suma, recorrer à teoria e aos métodos antropológicos permitiu desenvolver uma concepção ampliada e interdisciplinar do processo formador, favorecendo a inclusão de conhecimentos locais sobre saúde, doença e cura e suas interfaces com territórios e culturas indígenas, potencializando o protagonismo dos AIS na valorização dos conhecimentos dos modos indígenas de viver, bem como de suas práticas de cura e cuidados.

\section{Diretrizes para a formação do AIS e a escolha do perfil profissional}

Na construção do plano de curso havia necessidade de buscar apoio em documentos e referenciais curriculares já existentes no país, para garantir o reconhecimento oficial do processo formativo. Entretanto, não havia uma política nacional para a profissionalização em saúde dos AIS. A Política Nacional de Atenção à Saúde dos Povos Indígenas (2002: 15) indicava apenas uma estratégia orientadora da qualificação dos AIS na qual reconhecia que:

A formação e a capacitação de indígenas como agentes de saúde é uma estratégia que visa favorecer a apropriação, pelos povos indígenas, de conhecimentos e recursos técnicos da medicina ocidental, não de modo a substituir, mas de somar ao acervo de terapias e outras práticas culturais próprias, tradicionais ou não.

Com base nessa formulação geral da Pnaspi, a Funasa, órgão federal responsável pela saúde indígena entre 1999 e 2010, formulou uma proposta de qualificação inicial denominada "Educação profissional básica para Agentes Indígenas de Saúde", organizada em seis módulos temáticos e totalizando 1.080 horas. Porém, a proposta não preconizava nenhuma articulação com o processo de elevação de escolaridade, tampouco previa uma titulação, se caracterizando como uma formação inicial sem reconhecimento 
profissional. Essa proposta foi iniciada em vários DSEl, e finalizada em poucos. Desde que a Sesai assumiu a gestão federal, a implementação dela foi descontinuada e somente em 2017 outra proposta foi divulgada. Assim, naquele momento, apesar da mudança em 2010 do gestor federal responsável pela saúde indígena para a Sesai, não havia novas diretrizes para o trabalho e a formação do AIS.

Além disso, as características das propostas de formação de AIS até então desenvolvidas eram discordantes das reivindicações do movimento indígena do Rio Negro, que demandava processos formativos que propiciassem a elevação da escolaridade, alcançando uma qualificação profissional em nível técnico. Na ausência de uma diretriz nacional específica para profissionalização em nível médio em saúde para os AIS, e tendo em foco que a proposta curricular a ser construída deveria basear-se em marcos legais e em referenciais curriculares já reconhecidos, a equipe se debruçou sobre alguns perfis profissionais técnicos da saúde existentes, com destaque para: técnico de enfermagem, técnico de vigilância em saúde e técnico em agente comunitário de saúde.

Nossa intenção era identificar o referencial nacional que melhor se aproximava dos debates do I Seminário para Formação Profissional dos Agentes Indígenas de Saúde do Alto Rio Negro, no qual se propôs que o perfil profissional dos AIS abrangesse quatro dimensões:

I) Conhecer o território

- Morar na comunidade e conhecer as condições de vida da população.

- Reconhecer as situações que protegem e ameaçam a vida das pessoas.

- Conhecer os recursos do território - plantas medicinais, pesca, caça, roça, entre outros.

- Coletar, sistematizar e analisar dados e informações do território.

2) Atuar no cuidado

- Compreender o processo saúde-doença e cuidado, com base em:

- saberes tradicionais;

- conhecimentos da medicina; e

- necessidades de saúde dos indivíduos e das populações.

- Participar no processo de cuidado tradicional e da medicina oficial.

- Acompanhar as pessoas em suas diferentes fases da vida (criança, jovem, veIho), identificando suas necessidades de saúde. 
- Atuar em ações de prevenção, promoção, tratamento e reabilitação.

- Articular as questões de saúde da comunidade com outros membros da equipe do DSEI.

3) Desenvolver aÇÃo política e COMUnitá́riA

- Compreender a organização do SUS e do Subsistema de Saúde Indígena.

- Mobilizar a comunidade em prol de ações em saúde, exemplos: vacinação, destinação de lixos, cuidado com a água parada, entre outras.

- Planejar, executar e avaliar ações em saúde, com destaque para as práticas de educação em saúde.

- Articular-se com outros setores da sociedade para resolver os problemas de saúde da comunidade.

- Participar com a comunidade das atividades de controle social.

- Refletir sobre a construção histórica do trabalho do AIS e seu papel no Subsistema de Saúde indígena.

4) Produzir informação e realizar atividades de educação em saúde

- Preencher formulários sobre as condições de vida e situação de saúde das pessoas.

- Informar à equipe sobre o acompanhamento das pessoas nos programas de puericultura, pré-natal, hipertensão e diabetes, entre outros.

- Realizar atividades educativas sobre os programas e ações de saúde desenvolvidos pela equipe multidisciplinar de saúde indígena.

O perfil de técnico em enfermagem era o mais conhecido pelos AIS, pois é um dos membros da equipe multidisciplinar em saúde indígena atuante nos DSEl, sendo inclusive um curso procurado por eles, individualmente, quando buscam profissionalização em saúde. Entretanto, historicamente, o perfil de técnico de enfermagem constituiuse no âmbito da execução de procedimentos biomédicos de cuidado dos indivíduos, sob supervisão do profissional de enfermagem de nível superior, e dependente do uso de tecnologias. O Catálogo Nacional de Cursos Técnicos (Brasil, 2016) destaca como campo de atuação dos técnicos de enfermagem os diversos níveis dos serviços de saúde, e como perfil de conclusão desse curso:

Realiza curativos, administração de medicamentos e vacinas, nebulizações, banho de leito, mensuração antropométrica e verificação de sinais vitais. Auxilia a promoção, preven- 
ção, recuperação e reabilitação no processo saúde-doença. Prepara o paciente para os procedimentos de saúde. Presta assistência de enfermagem a pacientes clínicos e cirúrgicos e gravemente enfermos. Aplica as normas de biossegurança. (Brasil, 20 I6: 20)

A análise desse perfil formador levou-nos a concluir não ser ele o mais adequado para o curso pretendido, já que o campo de atuação do AIS é a comunidade, onde desenvolvem atividades de forma praticamente autônoma, posto que a supervisão de enfermagem é inconstante. Ademais, em nossa concepção sobre o trabalho do AIS, esse profissional não deveria se restringir ao cuidado dos indivíduos, mas abarcar também a saúde dos coletivos, com ênfase nas atividades de promoção da saúde e prevenção das doenças. Nesse sentido, consideramos que a formação do técnico de enfermagem, apesar das mudanças nos últimos anos, ainda está fortemente alicerçada nos conhecimentos biomédicos e na atuação individual focada na doença.

Já o perfil profissional de técnico em vigilância em saúde tinha maior ênfase em dimensões coletivas, visto que previa:

desenvolver ações de inspeção e fiscalização sanitárias; aplicar normas relacionada a produtos, processos, ambientes, inclusive do trabalho, e serviços de interesse da saúde; investigar, monitorar e avaliar riscos e os determinantes dos agravos e danos à saúde e ao meio ambiente. (Brasil, 20।6: 42)

Como limitação do perfil, reconhecemos que embora atuasse no âmbito dos determinantes da saúde, trata-se de uma formação focada nas grandes áreas da vigilância (vigilância sanitária, saúde do trabalhador, vigilância ambiental e vigilância epidemiológica), que não guardavam equivalência com a amplitude da atuação dos AIS. Além disso, não contemplavam a capacitação para atuar na prestação de cuidados em âmbito individual, uma faceta de atuação insistentemente demandada pelas comunidades de origem dos AIS.

Dessa forma, o grupo identificou o perfil do técnico em agente comunitário de Saúde (Brasil, 20I6) como o mais afinado com a perspectiva do trabalho do AIS na equipe multiprofissional e nas comunidades, uma vez que é reconhecido como aquele que:

Orienta e acompanha famílias e grupos em seus domicílios. Identifica e intervém nos múltiplos determinantes e condicionantes do processo saúde e doença, para a promoção da saúde e redução de riscos à saúde da coletividade. Realiza mapeamento e cadastramento de dados sociais, demográficos e de saúde. Desenvolve suas atividades norteadas pelas diretrizes, princípios e estrutura organizacional do Sistema único de Saúde. Promove comunicação entre equipe multidisciplinar, unidade de saúde, autoridades e comunidade. (Brasil, 2016: 15)

O Referencial Curricular para CTACIS foi aprovado em 2004, e prevê que a formação técnica de Agentes Comunitários de Saúde seja desenvolvida num itinerário formativo 
articulado com a elevação da escolaridade (Brasil, 2004), característica que atendia a uma das mais enfáticas demandas das lideranças indígenas rionegrinas.

Segundo as recomendações desse Referencial Curricular, o Curso Técnico de Agente Comunitário de Saúde é desenvolvido em três etapas formativas, com diferentes requisitos para ingresso. Na Etapa Formativa I não se exige nenhum comprovante de escolaridade. A Etapa Formativa II demanda a matrícula no ensino fundamental, ao passo que na Etapa Formativa III há a exigência de matrícula no ensino médio (Brasil, 2004). Essa característica de conformação de um itinerário formativo foi considerada estratégica para a situação de escolaridade dos AIS do Alto Rio Negro e pesou positivamente para a escolha desse referencial curricular para nossa proposta formativa.

Adotando esse referencial de curso técnico, foi possível articular a profissionalização dos AIS com a elevação de sua escolaridade, o que demandou o estabelecimento de parcerias com as secretarias estadual (Seduc/AM) e municipal (Semec/SGC) de educação. Ambas se organizaram e implementaram, articuladamente com o curso técnico, o nivelamento da escolarização, em nível de ensino fundamental e posteriormente de ensino médio, de todos os AIS matriculados no curso. Assim, em 2012, todos os AIS matriculados puderam concluir o ensino médio em tempo hábil para a conclusão do curso técnico, em 2015. A escolarização dos alunos matriculados no curso, em 2009, estava distribuída como no Quadro I.

\section{Quadro I - A escolaridade inicial dos alunos matriculados no CTACIS, 2009}

\begin{tabular}{|l|c|c|}
\hline Escolaridade inicial & Total no início & Porcentagens \\
\hline Sem escolaridade formal (sabe ler e escrever) & 26 & $13,7 \%$ \\
\hline Até ensino fundamental completo & 125 & $66,13 \%$ \\
\hline Ensino médio completo & 38 & $20,10 \%$ \\
\hline Ensino técnico em saúde & 0 & $0 \%$ \\
\hline Total alunos matriculados & 189 & $100 \%$ \\
\hline
\end{tabular}

Em abril de 2015, como resultados dos processos de elevação de escolaridade e profissionalização, obteve-se (ver Quadro 2): 


\section{Quadro 2 - Escolaridade de AIS matriculados no CTACIS, em abril de 2015}

\begin{tabular}{|l|c|c|}
\hline Escolaridade final & Total em 2015 & Porcentagens \\
\hline Sem escolaridade & 0 & $0 \%$ \\
\hline Ensino fundamental completo & 148 & $78,3 \%$ dos matriculados \\
\hline Ensino médio completo & 155 & $100 \%$ da demanda* \\
\hline Curso técnico completo & 139 & $73,54 \%$ dos matriculados \\
\hline Abandono do curso técnico & 50 & $26,45 \%$ dos matriculados \\
\hline Total alunos matriculados & 189 & $100 \%$ \\
\hline
\end{tabular}

*O acesso ao ensino médio também proporcionado a AIS que não estavam matriculados no curso técnico.

Definida a base nacional de referencial curricular para orientar o curso, a equipe do projeto trabalhou na adequação do currículo às premissas e diretrizes da educação escolar indígena e às características e necessidades da realidade local. É importante destacar que tal elaboração contou com uma equipe multidisciplinar da qual participaram especialistas em educação indígena, antropólogos, especialistas em formação técnica de ACS que atuaram sob a supervisão e apoio de lideranças do movimento indígena rionegrino.

A formalização e legalização da proposta formativa foi feita por meio de discussões políticas com os gestores locais e nacionais da saúde indígena, da Funasa e posteriormente da Sesai. Nas instâncias da educação, o curso contou com a aprovação do Conselho Estadual de Educação do Amazonas, em 2009. Também se formalizou um Termo de Convênio n. 02/20 10 de assistência técnica e pedagógica entre o estado do Amazonas, por meio da Secretaria de Estado de Educação e Qualidade do Ensino, e a Fiocruz para execução do CTACIS.

A execução do curso ficou a cargo de diversos parceiros, e o processo de elevação da escolaridade foi implementado pela Gerência de Educação Escolar Indígena da Secretaria de Estado de Educação e Qualidade do Ensino do Estado do Amazonas. As etapas do CTACIS foram implementadas pelo ILMD/Fiocruz e EPSJV/Fiocruz, com apoio do DSEIRN. O curso foi apoiado (política e financeiramente) pela Secretaria de Educação Continuada, Alfabetização, Diversidade e Inclusão (Secadi) do Ministério da Educação e, após sua conclusão, o relatório de execução foi avaliado positivamente pela Secretaria de Educação Profissional e Tecnológica (Setec/MEC). 


\section{A organização curricular do CTACIS}

Antes de apresentarmos a estrutura curricular do CTACIS, consideramos importante discutir as concepções de currículo adotadas, visando explicitar nossas concepções de educação escolar indígena, interculturalidade e saúde. O entendimento do currículo como campo de conhecimento é tema central nas teorias curriculares. Nessa perspectiva a definição de objetivos e conteúdo de ensino ganha relevo no planejamento curricular. $\mathrm{Na}$ leitura marxista do currículo, a escola tem um papel importante na reprodução das desigualdades sociais e o currículo expressa as diferenças de poder em relação aos valores e conhecimentos que transmite. Ao mesmo tempo, essa perspectiva destaca a possibilidade de emancipação dos sujeitos ao ofertar um conjunto de conhecimentos que permite a ação social. Entretanto, mesmo as visões mais críticas do currículo tratam os sujeitos como homogêneos e iguais.

O currículo é também uma construção social, e como tal, expressa a produção de sentidos e relações de poder. Segundo Macedo (2006: 288), o currículo pode ser entendido como um "espaço-tempo de fronteira no qual interagem diferentes tradições culturais e em que se pode viver de múltiplas formas". Na sua formulação e implementação cotidiana, as diferenças dos múltiplos pertencimentos culturais são negociadas: "Nele convivem as culturas locais dos variados pertencimentos de alunos e professores com as culturas globais, majoritárias tanto nos currículos escritos quanto, possivelmente, nos vividos nas salas de aula" (Macedo, 2006).

O currículo entendido como um híbrido cultural é pertinente para a análise da experiência curricular do CTACIS, pois lidamos com sujeitos e conteúdos com diferentes pertencimentos culturais e sociais, o indígena e o não indígena (Macedo, 2006). Conforme vimos anteriormente, o reconhecimento étnico dos povos indígenas no âmbito escolar tem sido uma disputa e tensão na história escolar dos povos indígenas.

Adotamos uma análise reflexiva entre o currículo formal e o currículo em ação, no sentido de ampliar a discussão curricular para além de sua proposição. Apesar de haver críticas a esse tipo de abordagem por reproduzir uma certa hierarquização, entendemos que ela contribui para a compreensão da multiplicidade do currículo, sua dinamicidade e relação com os contextos sociais, para envolver as experiências não previstas e as ausências de conteúdos e experiências. 


\section{Estrutura e conteúdos curriculares do CTACIS}

Focaremos a discussão da organização curricular nos componentes relativos à profissionalização em saúde, mas é importante assinalar que os AIS do Alto Rio Negro cursaram 1.800 horas de ensino médio, entre 2010 e 2012, organizado e implementado pela Secretaria de Estado de Educação e Qualidade do Ensino através da Gerência de Educação Escolar Indígena (Seduc/Deppe/Geei).

O Referencial Curricular Nacional de Curso Técnico de Agente Comunitário de Saúde (Brasil, 2004) propõe uma carga horária mínima de 1.200 horas, porém, seguindo recomendações do Conselho Estadual de Educação do Amazonas, adicionou-se mais 20\% de carga horária para prática profissional, exigência para os cursos da saúde no estado. Assim, o curso técnico totalizou uma carga horária curricular de 1.440 horas, distribuídas em três Etapas Formativas: 480 horas na etapa I, 740 horas na etapa II e 240 horas na etapa III.

A expectativa inicial de matrícula de 250 AIS no curso foi redimensionada para incluir somente aqueles efetivamente contratados pelo DSEIRN e Secretaria Municipal de Saúde, conforme decisão negociada entre lideranças indígenas e gestores locais, já que uma contratação prevista para 6 I novos agentes não se efetivou. Dessa forma, o número de matriculados no curso foi de I 89 AIS, que foram distribuídos em cinco polos formativos conforme a Figura I.

Figura I - Mapa da região do Alto Rio Negro, com distribuição dos polos formativos

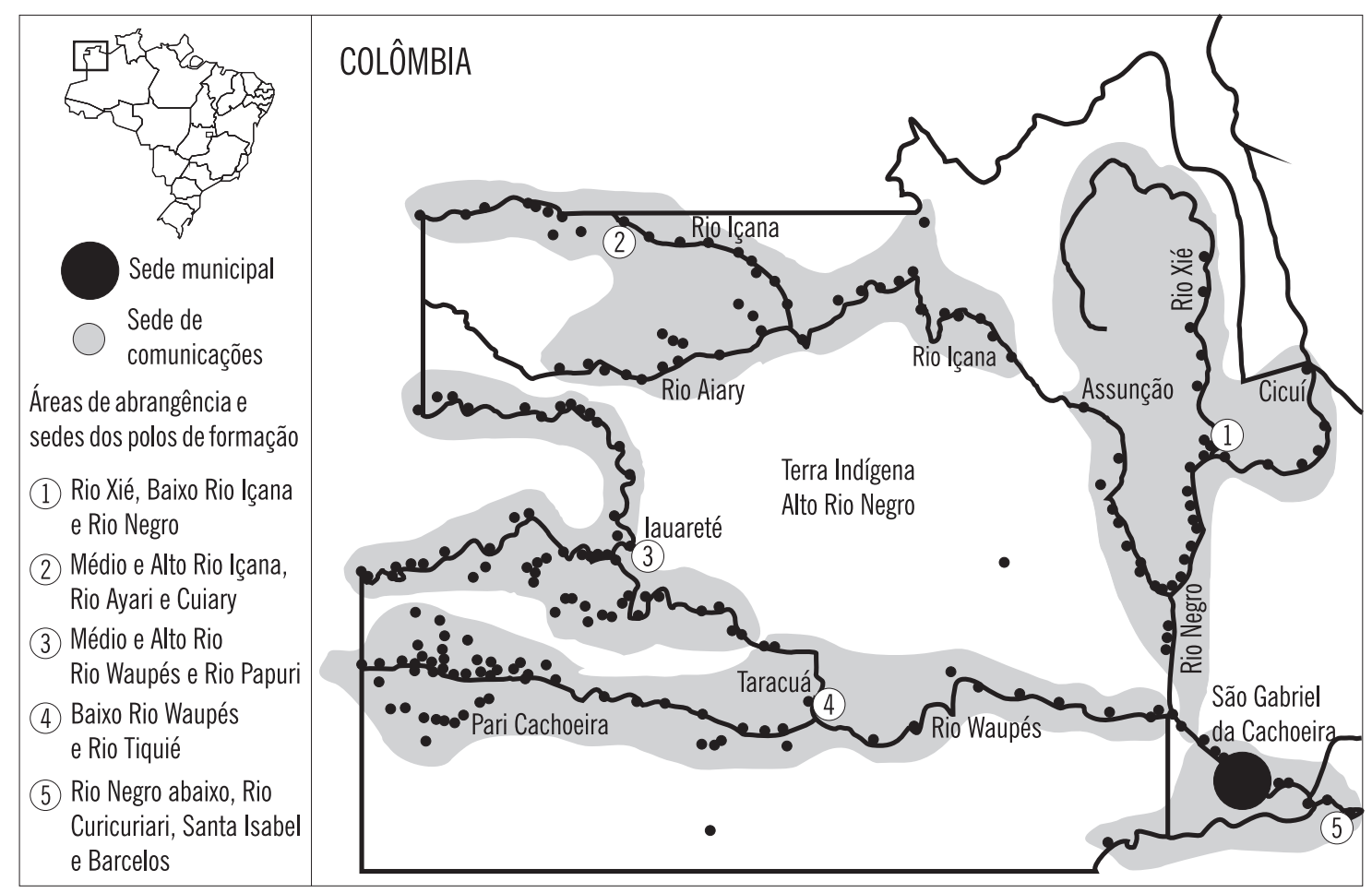

Fonte: adaptado de Isa, 1998. 
A distribuição em polos formativos buscava dar conta da especificidade da distribuição espacial das etnias que formam o mosaico cultural rionegrino e que orientam também a distribuição das unidades e equipes de saúde do DSEl Alto Rio Negro. Além disso, visava também facilitar o acesso e a adesão dos alunos ao curso, mediante a interiorização do processo formador e seus agentes, invertendo a lógica habitual de deslocar os estudantes para o espaço urbano, afastando-os das aldeias. No plano educativo, tal decisão compromete a experiência curricular com as especificidades do modo de vida do grupo étnico com o qual se relaciona no processo formador.

O polo formativo I Rio Xié, Baixo Rio Negro e Rio Negro englobou os AIS pertencentes a comunidades indígenas distribuídas na calha do Rio Negro, incluindo também aquelas mais próximas do centro urbano de São Gabriel da Cachoeira. Nesse polo predominaram os falantes de nheengatu ou língua geral, corrente entre as etnias baré e werekena, esses últimos residentes no rio Xié, afluente do Rio Negro. O polo formativo 2 Médio e Alto Rio Içana, Rio Aiari e Cuiary englobava principalmente as etnias baniwa e coripaco, falantes de línguas com a mesma designação vinculadas ao tronco linguístico aruaque. O polo formativo 3 Médio e Alto Waupés e Rio Papuri reuniu falantes da língua tukano, predominantemente das etnias tukano e tariano, mas também de outras etnias com quem esses mantêm relações de afinidade matrimonial. O polo formativo 4 Baixo Rio Waupés e Rio Tiquié congregou membros das mesmas etnias do polo 3, sendo formado por razões de proximidade geográfica, que configura essa como uma microrregião etnopolítica distinta dos altos trechos do rio Waupés e de seu afluente Papuri, embora vinculada ao mesmo tronco linguístico. O polo formativo 5 Baixo Rio Negro, Rio Cuicuriari, Santa Isabel e Barcelos congregou AIS provenientes de uma região formada pela fronteira entre o município de São Gabriel da Cachoeira com municípios vizinhos. Trata-se de um espaço multiétnico, gerado pela migração de membros de múltiplas etnias advindas dos altos rios, a maioria falantes de nheengatu e fluência em português, com acesso facilitado aos centros urbanos da região.

A organização dos polos formativos por proximidade étnica e geográfica mimetizava a rede prévia de relações que aldeias e etnias já mantinham entre si, permitindo que os estudantes se sentissem mais confortáveis, ao mesmo tempo que ressaltava as diferenças resultantes da composição étnica característica de cada polo. Além da organização das turmas por proximidade étnica, a atuação de antropólogos e outros pesquisadores com conhecimento prévio sobre as etnias que frequentavam o curso auxiliou o corpo docente a entender as especificidades de cada grupo no planejamento e realização das aulas.

Diante da amplitude do território e das características dos estudantes (adultos, chefes de família com responsabilidades comunais e vinculados ao mercado de trabalho), 
optou-se pelo desenvolvimento do curso por meio de períodos de concentração, em que os alunos de cada polo formativo se reuniam numa localidade para estudar por um período determinado; e dispersão, quando os estudantes realizavam a prática profissional em suas comunidades. A proporção foi de cerca de $80 \%$ da carga horária de concentração e $20 \%$ na dispersão. A prática profissional também ocorria durante os períodos de concentração, com o objetivo de favorecer a supervisão. Para o período de dispersão, os estudantes recebiam por escrito orientações sobre as atividades que deveriam desenvolver e as formas de registro delas para posterior avaliação.

Infelizmente, a grande dificuldade logística e os elevados custos envolvidos inviabilizaram a realização de um acompanhamento contínuo das atividades de dispersão, que ocorreu somente durante a Etapa Formativa I, para quatro polos. Apenas no polo formativo 2, cujos supervisores dispunham de recursos adicionais para acompanhar os baniwa e coripaco, ocorreu supervisão também na Etapa Formativa II. Os propósitos de delegar a responsabilidade de supervisão aos enfermeiros das Emsis que atuavam no DSEI, muitos dos quais haviam atuado como docentes nos cursos, foram frustrados pela irregularidade de entrada deles nas terras indígenas.

Avaliamos que a limitada supervisão das atividades de dispersão representou um problema que precisa ser superado em outras experiências mediante incorporação do custo dessa atividade no orçamento do curso, embora ressalvando-se que na vasta extensão geográfica do Alto Rio Negro, tal incorporação tivesse duplicado (ou mesmo triplicado) o custo do processo formador, inviabilizando-o. Entretanto, em outras regiões do país com terras indígenas de menor extensão e de mais fácil acesso, o custo das ações de supervisão pode se mostrar mais razoável. Uma alternativa tentada no CTACIS, que nos parece adequada, foi a incorporação da supervisão dos AIS nas atividades rotineiras dos profissionais que atuam no DSEl. Essa estratégia tem a vantagem de vincular de modo mais estrito os profissionais das equipes ao processo formador dos AIS. Em regiões com maior regularidade de atuação dos profissionais da Emsi, essa alternativa de supervisão pode se mostrar mais adequada, desde que esses se envolvam nas atividades didáticas da fase de concentração. Entretanto, as visitas de supervisão feitas pela equipe de coordenação do curso foram fundamentais para redirecionar a implementação curricular, conforme se detalha mais adiante.

A estrutura curricular inicialmente elaborada organizou-se em cinco eixos, que agregavam os diferentes conteúdos, e eram denominados: Cultura, Território, Política, Cuidado e Informação, Comunicação e Planejamento em Saúde, distribuídos nas três etapas conforme a Figura 2. 
Figura 2 - Organização curricular prevista no plano de curso CTACIS

\begin{tabular}{|c|c|c|c|c|c|}
\hline \multicolumn{2}{|c|}{$\begin{array}{l}\text { I Etapa Formativa } \\
\text { Conhecer o território }\end{array}$} & \multicolumn{2}{|c|}{$\begin{array}{l}\text { II Etapa Formativa } \\
\text { Analisar as condições de vida e } \\
\text { situações de saúde }\end{array}$} & \multicolumn{2}{|c|}{$\begin{array}{l}\text { III Etapa Formativa } \\
\text { Intervindo sobre os problemas e } \\
\text { necessidades de saúde }\end{array}$} \\
\hline \multirow{2}{*}{ Eixo Cultura } & \multirow{5}{*}{ 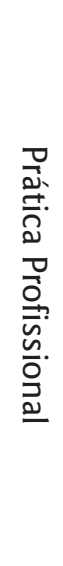 } & Eixo Cultura & \multirow{5}{*}{ 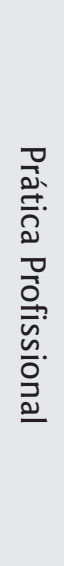 } & Eixo Cultura & \multirow{5}{*}{$\begin{array}{l}0 \\
0 \\
0 \\
0\end{array}$} \\
\hline & & Eixo Território & & Eixo Território & \\
\hline Eixo Território & & Eixo Cuidado & & Eixo Cuidado & \\
\hline Eixo Cuidado & & Eixo Política & & Eixo Política & \\
\hline Eixo Política & & $\begin{array}{l}\text { Eixo Informação, } \\
\text { Comunicação e } \\
\text { Planejamento em Saúde }\end{array}$ & & $\begin{array}{l}\text { Eixo Informação, } \\
\text { Comunicação e } \\
\text { Planejamento em Saúde }\end{array}$ & \\
\hline
\end{tabular}

A lógica das três etapas foi construída com base nos referenciais metodológicos da vigilância em saúde, o processo formativo se inicia a partir de um diagnóstico comunitário (Etapa Formativa I), seguido da análise dos problemas e situações de risco (Etapa Formativa II), para, por fim, realizar-se o planejamento estratégico para a atuação no território (Etapa Formativa III). Assim, as três etapas formativas foram denominadas:

- Etapa Formativa I (480 horas): Conhecer o território para intervir.

- Etapa Formativa II (720 horas): Analisar a situação de saúde e as condições de vida da população do território. Identificar situações de risco e vulnerabilidade.

- Etapa Formativa III (240 horas): Intervir nos problemas e necessidades de saúde.

Entretanto, essa estrutura sequencial de passos se mostrou inadequada na medida em que os agentes e lideranças questionaram a pertinência e a utilidade dos conhecimentos adquiridos se não fossem imediatamente aplicados ao enfrentamento dos problemas e à melhoria da saúde da população. Trata-se aqui de um conflito lógico entre os modos de operação do pensamento acadêmico que fraciona a realidade em aspectos e fases, e a epistemologia nativa que concebe o mundo em totalidade e recusa a distinção entre o saber e o fazer, uma vez que a práxis indígena reconhece indissociabilidade no saber-fazer.

Além disso, de forma coerente com esse modo de pensar, as supervisões realizadas ao longo da Etapa Formativa I haviam demonstrado relutância dos comunitários em participar das atividades de dispersão, voltadas essencialmente para o diagnóstico de situações, sem a concomitante discussão sobre como abordar os problemas identificados. Essa atividade tinha sido concebida para ser desenvolvida apenas na 
Etapa Formativa III do curso, o que nos obrigou a rever a concepção pedagógica de apoio à implementação da matriz curricular.

A saída para esse impasse foi adotar as premissas da vigilância em saúde como estratégia metodológica orientadora para o desenvolvimento dos conteúdos, evitando a separação por etapas, e passando a explorar cada tema formativo de modo integrado, abrangendo diagnóstico, análise e planejamento e execução das ações a serem desenvolvidas em sala de aula e na comunidade, somente então passando a abordar o tema seguinte. Em consequência, tivemos uma alteração no processo de desenvolvimento do currículo. A Etapa Formativa I manteve a organização por eixos, conforme inicialmente planejado, mas as Etapas Formativas II e III foram reorganizadas como blocos temáticos, recompondo os conteúdos previstos nos eixos temáticos, conforme a Figura 3.

Figura 3 - Organização final da estrutura curricular do CTACIS

\begin{tabular}{|c|c|c|c|c|c|c|c|}
\hline \multicolumn{2}{|c|}{$\begin{array}{l}\text { I Etapa Formativa } \\
\text { CH } 480 \mathrm{~h}\end{array}$} & \multicolumn{3}{|c|}{$\begin{array}{l}\text { II Etapa Formativa } \\
\text { CH } 720 \mathrm{~h}\end{array}$} & \multicolumn{3}{|c|}{$\begin{array}{l}\text { III Etapa Formativa } \\
\text { CH } 240 \mathrm{~h}\end{array}$} \\
\hline \multirow{2}{*}{ Eixo Cultura } & \multirow{6}{*}{ 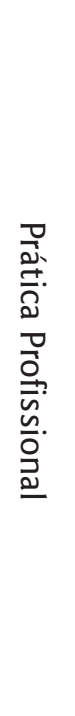 } & Saúde da Criança & \multirow{6}{*}{ 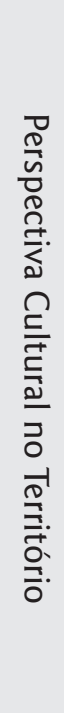 } & \multirow{6}{*}{ 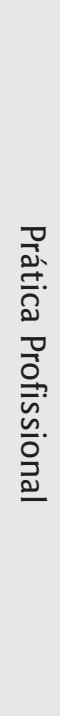 } & \multirow{3}{*}{$\begin{array}{l}\text { Suporte básico } \\
\text { de vida, primeiros } \\
\text { socorros e } \\
\text { biossegurança }\end{array}$} & \multirow{6}{*}{ 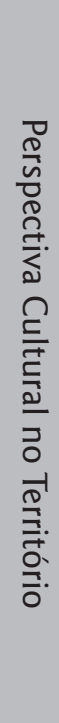 } & \multirow{6}{*}{ 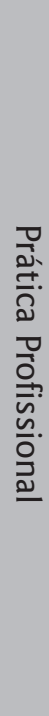 } \\
\hline & & Saúde da Mulher & & & & & \\
\hline Eixo Território & & Saúde Bucal & & & & & \\
\hline Eixo Cuidado & & Condições crônicas & & & $\begin{array}{l}\text { Educação em } \\
\text { saúde e produção } \\
\text { de material } \\
\text { educativo }\end{array}$ & & \\
\hline \multirow{2}{*}{ Eixo Política } & & $\begin{array}{l}\text { Vigilância } \\
\text { dos agravos } \\
\text { transmissíveis }\end{array}$ & & & \multirow{2}{*}{$\begin{array}{l}\text { Planejamento em } \\
\text { saúde: perfil de } \\
\text { atuação do ACIS }\end{array}$} & & \\
\hline & & $\begin{array}{l}\text { Políticas de } \\
\text { inclusão social }\end{array}$ & & & & & \\
\hline
\end{tabular}

Cabe lembrar que no desenvolvimento dos blocos temáticos das Etapas Formativas I, II e III foram mantidas discussões relativas a temas como cultura, território, política e cuidado que transversalizaram o processo formador. Ou seja, no desenvolvimento de temas como saúde da criança, da mulher e outros, foram discutidas, além das dimensões técnicas que envolvem o cuidado a esses grupos populacionais, concepções e práticas tradicionais relativas ao tema, expressões étnico-territoriais desses problemas de saúde, política de saúde materno-infantil ou da saúde bucal, e assim por diante. O modo como os temas fundamentados na Etapa Formativa I transversalizaram as etapas subsequentes é demonstrado com maior clareza nos capítulos subsequentes. 
A seleção de temas relativos aos blocos temáticos se apoiou em discussões com as equipes multidisciplinares do DSEIRN - aí incluídos os agentes de saúde -, nas diretrizes da organização da Atenção Primária do Ministério da Saúde e em pesquisas sobre perfil epidemiológico na região, orientando a identificação de problemas prioritários para guiar a futura atuação dos AIS. A prática profissional se manteve presente nas concentrações e dispersões, proporcionando informações permanentes para comunidades, lideranças locais e para os profissionais do DSEl sobre os novos conteúdos aprendidos e novas atribuições dos AIS no trabalho com as comunidades.

Consideramos que a nova organização curricular foi mais favorável para articular as dimensões teórico-prática e conhecimentos indígenas e não indígenas. Cada temática abordada na Etapa Formativa II seguia uma sequência de passos, que adaptamos com base nas diretrizes do Planejamento Estratégico Situacional.

Passo I - Diagnóstico territorial da temática: qual a característica da população afetada? Qual território é afetado? Quais características socioculturais a questão apresenta? Quais conhecimentos indígenas existem sobre a temática? Que informações em saúde estão disponíveis?

Passo 2 - Priorização dos problemas: com base nas perspectivas dos AIS, comunidades, profissionais da saúde e da Política Nacional, quais questões são mais relevantes no território?

Passo 3 - Aprofundamento dos problemas: explorar, com base nas perspectivas indígena e não indígena, os diferentes aspectos dos problemas e potenciais alternativas de abordagem.

Passo 4 - Planejamento das ações dos AIS: priorizar e programar ações de saúde a serem desenvolvidas pelos AIS para abordar o problema reconhecido e priorizado no passo anterior. Organização e detalhamento das rotinas de trabalho dos AIS nas comunidades e junto a Emsi para abordar o problema em tela.

Passo 5 - Organização do sistema local de informação: como registrar e analisar as informações disponíveis e avaliar as ações e enfrentamento dos problemas no espaço da aldeia e no nível de competência do agente de saúde? Como sistematizar informações para repassá-las aos outros membros da Emsi?

Na Etapa Formativa III agregamos alguns conteúdos específicos considerados estratégicos: suporte básico de vida, primeiros socorros e biossegurança. Além disso foram elaboradas estratégias de educação em saúde com produção de materiais educativos e realizado planejamento global das novas atribuições do AIS para atuar como técnico de nível médio. 
Resumidamente os conteúdos abordados nas etapas formativas foram:

\section{ETAPA Formativa I}

Discussão do conceito de saúde articulado aos conceitos de território, meio ambiente, condições de vida e cultura e história.

Eixo Cultura:

- Processos produtivos (alimentação, moradia e transporte) e modos de vida nos territórios indígenas.

- História de contato e movimento indígena.

- Mitos, parentesco e doenças tradicionais.

Eixo Território:

- Noções de cartografia.

- Discussão do conceito de espaço geográfico e espaço relacional.

- Discussão do conceito de território.

- Demografia e população: construção da pirâmide populacional.

- Condições de vida e saúde no território, aplicação de questionário para todas as famílias.

Eixo Política:

- Conceito de política, política indígena e indigenista.

- Sustentabilidade, associativismo e saúde.

- História das políticas de saúde (nacional e indígena).

- SUS e seus princípios.

- Histórico e princípios da APS.

- Diretrizes e funcionamento da política de saúde indígena: DSEI.

- Histórico e regulamentação do trabalho do AIS e do ACS.

Eixo Cuidado:

- Conceito de saúde e de seus determinantes sociais.

- Práticas de saúde (promoção, prevenção e assistência).

- Modelos de atenção (biomédico e vigilância).

- Sistemas tradicionais de cura e cuidados. 
- Fases da vida e seus cuidados no mundo indígena.

- Alimentação, vigilância alimentar e nutricional: classificação dos alimentos e pirâmide alimentar, transição alimentar e nutricional, segurança alimentar.

- Situação nutricional dos povos indígenas.

- Puericultura e Cartão da Criança.

- Avaliação nutricional e funcionamento do Sistema de Vigilância Alimentar e Nutricional (Sisvan): técnicas e formulários de sistema de informação.

- Problemas nutricionais: diarreia, desidratação, desnutrição e anemia.

Discussão sobre educação em saúde: preparação e apresentações sobre o tema para a comunidade.

ETAPA Formativa II

Organização da APS:

- Revisão: determinantes sociais da saúde, ações de promoção, prevenção e assistência.

- Princípios da organização da APS e o trabalho do AIS.

- A visita domiciliar do AIS.

- Diagnóstico comunitário.

Saúde da criança:

- Caracterização e diagnóstico da infância no território indígena.

- Classificação nativa das fases da vida infantil.

- Cuidados tradicionais e práticas alimentares das crianças indígenas.

- Priorização dos problemas na saúde da criança: comunidade indígena, AIS e política nacional de saúde.

- Determinantes e condicionantes do crescimento e desenvolvimento saudável do ponto de vista nativo e das equipes de saúde.

- Revisão puericultura e Cartão da Criança.

- Revisão antropometria e Sisvan: técnicas e formulários.

- Vigilância alimentar e nutricional: rotina alimentar, alimentos disponíveis e construção de orientações.

- Aleitamento materno.

- Bolsa Família. 
- Imunização e Programa Nacional de Imunização (PNI): histórico, conceitos, doenças imunopreviníveis, vacinas, calendário vacinal, trabalho da equipe e do AIS.

- Adoecimento infantil: situação no Alto Rio Negro, doenças prevalentes, condicionantes e determinantes do adoecimento, AIDPI (sinais de perigo, tosse, febre, diarreia e dor de ouvido).

- Organização das rotinas e das visitas domiciliares do AIS no âmbito da saúde da criança.

Saúde da Mulher:

- Caracterização e diagnóstico da vida e saúde da mulher no território indígena.

- Fases da vida da mulher indígena e cuidados tradicionais.

- Priorização dos problemas de saúde no território indígena, na cidade e em território nacional.

- Pré-natal: conceitos, técnicas e formulários.

- Vigilância nutricional da gestante, práticas alimentares e dietética tradicional.

- Sisvan.

- Aleitamento materno.

- Saúde bucal da gestante.

- Intercorrências clínicas na gravidez.

- Condições e realização do parto e acompanhamento do puerpério (no DSEI e no contexto indígena).

- Planejamento familiar.

- Controle e monitoramento dos principais agravos à saúde da mulher.

- Prevenção do câncer de colo de útero.

- Organização das rotinas e visita domiciliar do AIS na saúde da mulher.

Saúde Bucal:

- Hábitos e usos culturais da dentição.

- Etnografia dos hábitos alimentares e higiene bucal.

- Anatomia da boca, fisiologia da dentição e importância da dentição decídua e consequência da perda precoce, implicações da dentição no desenvolvimento da face, da fala e da mastigação, e complicação sistêmica dos problemas dentários. 
- Alimentação e higienização oral (não associada à dentição) na criança e nas gestantes; técnica de escovação; trabalho de higienização com as crianças; práticas coletivas sobre escovação; e prevenção em saúde bucal (flúor, escovação e outros).

- Produção de material educativo sobre saúde bucal.

- Doenças prevalentes na infância e na gestante: cáries e perda precoce dos dentes.

- Sistema de informação em saúde bucal.

Condições crônicas:

- Conceito de condições crônicas, agudização de condições crônicas e condições agudas, segundo o modo de vida indígena.

- Perfil epidemiológico das doenças crônicas não transmissíveis no Brasil e no DSEIRN.

- Programa de prevenção e controle da hipertensão: características epidemiológicas e clínicas, estratégias de rastreamento e monitoramento, aferição de pressão arterial (PA), acompanhamento do portador de hipertensão arterial sistêmica e crise hipertensiva.

- Programa de Controle do Diabetes Mellitus tipo II: características clínicas e classificação do diabetes, fluxograma de acompanhamento, controle medicamentoso, complicações (agudas e crônicas), monitoramento de lesões dos pés e outros agravos decorrentes e teste rápido de glicemia.

-Transição alimentar.

- Avaliação nutricional do adulto e do idoso.

- Estratégias de educação em saúde.

- Saúde do trabalhador indígena.

- Organização do trabalho do AIS no controle das doenças crônicas não transmissíveis.

Vigilância das doenças transmissíveis:

- Condições de vida, ambiente e saúde.

-Vigilância epidemiológica das doenças transmissíveis.

- Programa de prevenção e controle da tuberculose: perfil epidemiológico, rastreamento de suspeitos, fluxo de tratamento, acompanhamento do tratamento e vigilância e educação em saúde.

- Programa de prevenção e controle da hanseníase. 
- Tracoma.

- Infecções sexualmente transmissíveis: abordagem sindrômica, métodos preventivos, educação em saúde e fluxo de acompanhamento.

- Doenças diarreicas agudas.

- Infecções respiratórias agudas.

- Controle e monitoramento da malária.

- Doenças preveníveis por imunizantes.

- Direitos sociais, inclusão social e intersetorialidade.

- Movimento indígena no rio Negro.

- Sustentabilidade no território indígena.

- Movimentos sociais em saúde.

- Profissionalização e regulamentação dos AIS.

- Previdência social e direitos trabalhistas.

- Políticas de inclusão social.

- Educação escolar indígena.

EtAPA Formativa III

Suporte básico de vida, primeiros socorros e biossegurança:

- Conceito de biossegurança.

- Acidentes com animais peçonhentos.

- Noções básicas de primeiros socorros e suporte básico de vida.

- Queimaduras.

- Ferimentos e curativos.

- Afogamento e transporte de pacientes.

Educação em saúde - produção de material educativo:

- Controle de doenças transmissíveis: malária.

- Jogo da saúde (saúde da mulher - atenção ao pré-natal de baixo risco, saúde da criança de 0 aos 5 anos, vigilância alimentar -, quadro de refeições e saúde e ambiente).

- Educação para a saúde da criança. 
• Educação em saúde sobre cuidados com a mulher grávida.

-Quadro de refeições do dia.

- Planejamento em saúde - perfil de atuação do AIS:

- Planejamento das ações do AIS no território.

- Atribuições do AlS.

A reestruturação das estratégias pedagógicas propiciou a superação dos aspectos estanques e disciplinares da concepção inicial de currículo, favorecendo abordagens interdisciplinares para a exploração das transversalidades subjacentes ao processo formador. Os conteúdos e atribuições desenvolvidos ao longo da implementação curricular permitiram identificar e construir novos modos de organização do trabalho do AIS na Emsi. As reflexões sobre esse novo perfil profissional técnico do AIS, que emergem do processo formador, estão apresentadas na Figura 4.

\section{Figura 4 - Representação dinâmica do currículo do CTACIS}

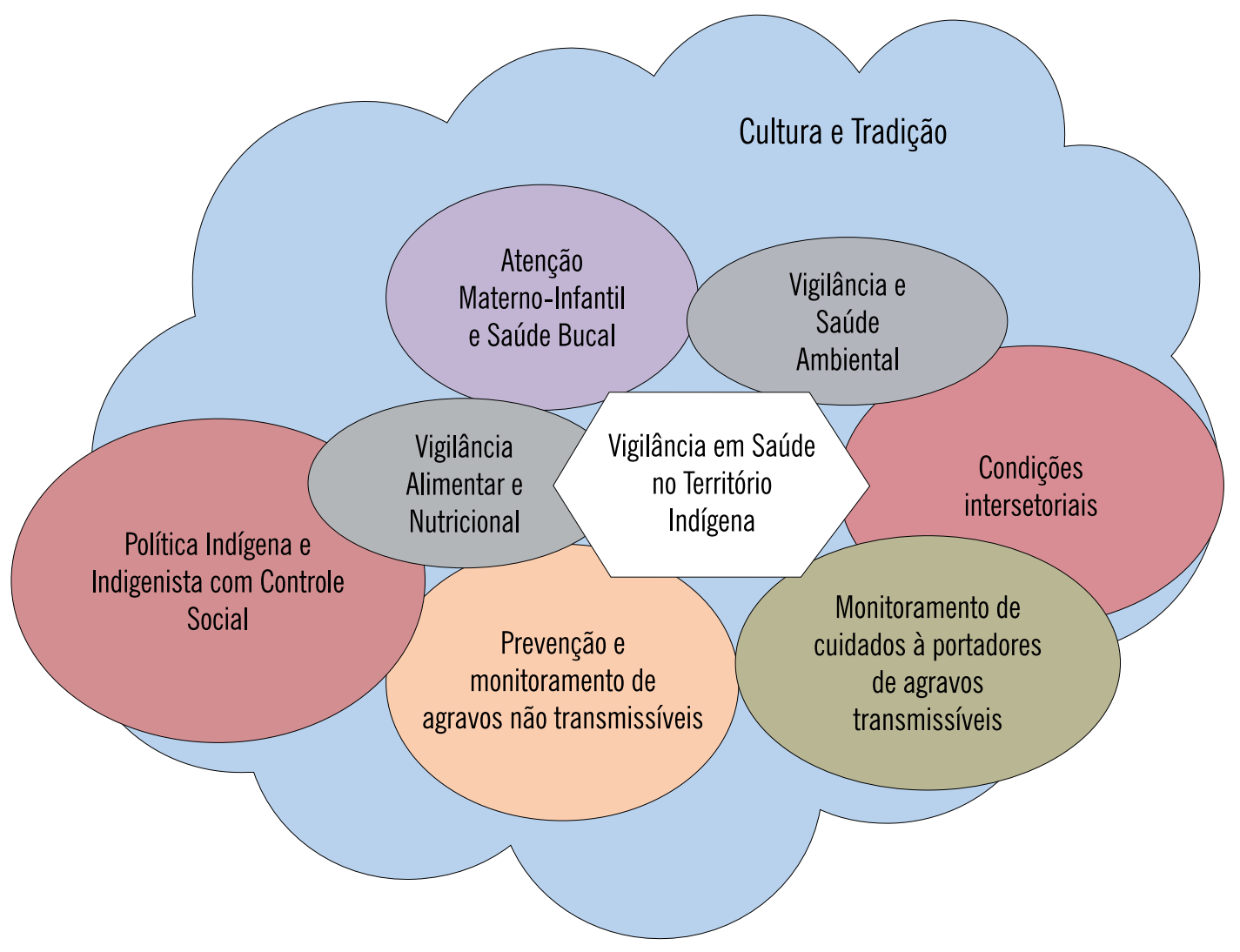


As formas arredondadas e as superposições presentes no diagrama são intencionais e visam chamar a atenção para as interfaces e confluências dos blocos temáticos apresentados na Figura 3, e que ao final do processo formador haviam se convertido em agregados temáticos mais amplos, como política indígena e indigenista, vigilância alimentar e nutricional e outros, que integram - e efetivam - o tema central orientador do processo formador e da atuação dos AIS, que é a vigilância em saúde no território indígena. O diagrama expressa a dialética do currículo como híbrido cultural experimentado como currículo formal na Figura 3 e como currículo em ação no diagrama da Figura 4.

A forma em nuvem da temática cultura e tradição evidencia sua interveniência como determinante sociocultural e como contexto orientador da atividade dos AIS, mediante o qual todas as atividades e técnicas aprendidas deverão se referir no dia a dia de seu labor. Também são apresentados na Figura 4 dois eixos permanentes e estruturantes de orientação do trabalho do AIS: a política indígena e indigenista com controle social e as ações intersetoriais. A centralidade do perfil de atuação de caráter mais técnico é representada pela vigilância em saúde no território indígena, da qual destacamos duas subdimensões da vigilância - a vigilância alimentar e nutricional e a vigilância e saúde ambiental -, relembrando, porém, que as atividades técnicas pertinentes ao trabalho do AIS são continuamente permeadas pelos saberes indígenas que permitem a extração, no território, de alternativas alimentares obtidas (ou produzidas) diretamente da natureza circundante, mediadas, portanto, pelo conhecimento tradicional indígena.

Com base no perfil epidemiológico produzido no processo formador foi possível destacar como áreas de atuação do AIS: a atenção materno-infantil e saúde bucal (voltada para esses grupos prioritários), a prevenção e monitoramento de agravos não transmissíveis e o monitoramento e cuidado a portadores de agravos transmissíveis. Dada a centralidade desses temas, o detalhamento do processo pedagógico relativo a eles será apresentado em outro momento.

\section{Outras reflexões sobre o currículo em ação}

Ainda em termos de currículo em ação é relevante informar que cada novo componente curricular era iniciado com o debate e a explicitação das concepções e conhecimentos locais sobre o tema, o que, via de regra, envolvia o estímulo à realização de pesquisas com conhecedores indígenas sobre tais dimensões da cultura, bem como a sistematização do material obtido pelos agentes de saúde, com apoio dos docentes do curso, expressando, em práxis, a premissa de ensino pela pesquisa preconizada pela educação escolar indígena. A participação generosa de lideranças do movimento indígena e de conhecedores tradicionais, xamãs e outros agentes de cura foi fundamental para 
a realização dessa fase do processo, uma vez que não havia publicações prévias sobre a maioria dos conteúdos curriculares trabalhados no curso, nas dimensões relativas às culturas indígenas presentes.

A escolha de uso das línguas indígenas nos espaços educativos foi fundamental para a valorização sociocultural, ao mesmo tempo, o curso tinha obrigação de zelar pelo desenvolvimento da competência no uso da língua portuguesa, o que auxiliava os estudantes na convivência e atuação junto ao sistema de saúde, bem como na luta por direitos diante da sociedade nacional. No CTACIS, buscamos trabalhar o bilinguismo, primeiramente pela aproximação étnico-linguística com os polos formativos (Figura I), e ao longo do curso pelo estímulo ao uso das línguas indígenas nas atividades pedagógicas orais e escritas.

Do lado docente as aulas foram, na maioria das vezes, conduzidas em português, pois os professores eram majoritariamente não falantes das línguas indígenas. Sem desconsiderar a limitação aí implicada, consideramos que essa dinâmica auxiliou os estudantes a ampliar seu domínio de língua portuguesa, que era a segunda língua para a maioria dos AIS; por isso, frequentemente, durante as aulas, eram necessárias pausas e traduções para as línguas indígenas. Esses momentos eram extremamente ricos porque estimulavam o debate entre os estudantes, o clareamento dos conceitos e a explicitação de dúvidas, que eram compartilhadas e esclarecidas entre os estudantes na sua própria língua. Nos exercícios em sala de aula também se estimulava a explicação, nas línguas indígenas, da solução dada por eles aos problemas trabalhados em sala. Os momentos de conversa em língua materna eram de tomada do ritmo e da condução da aula pelos AIS, nos quais os professores eram convidados a serem espectadores.

Em vários momentos do curso foram convidados conhecedores locais e lideranças indígenas que ministravam suas aulas em sua língua indígena de origem. Nessas ocasiões, se pedia para os estudantes produzirem relatos em suas línguas indígenas nativas, quando possível, e em português, estimulando o bilinguismo e exercitando a tradução de saberes. Durante as atividades em grupo, os debates entre pares sempre se realizavam em língua materna e as apresentações em plenária também podiam ser feitas em sua língua indígena, seguida de tradução para os professores. Estimulou-se a produção de cartazes, textos, peças e dramatizações em línguas indígenas, inclusive para os conteúdos mais técnicos do curso, com o objetivo de estimular o exercício do bilinguismo e construir de forma coletiva a tradução para as comunidades desses temas. Também se fomentava o debate sobre as dificuldades em construir material educativo nas línguas indígenas. Trata-se de um processo que envolve muito mais do que a tradução de uma língua para outra, como também a reconstrução de conceitos que existem num 
universo vocabular, mas não no outro, e que precisam ser entendidos em profundidade para que possam ser explicados a terceiros.

Infelizmente, como corpo docente, não fomos capazes de produzir material didático bilíngue em razão da complexidade do trabalho e da diversidade linguística da região. Assim, os textos distribuídos em sala para leitura foram todos em português. Para auxiliar a leitura e interpretação de textos utilizaram-se recursos como a consulta recorrente ao dicionário da língua portuguesa e a leitura pausada de cada texto, com a identificação e esclarecimento das palavras desconhecidas. Esse processo propiciou uma ampliação gradativa da linguagem escrita, em português, pelos discentes. O material educativo bilíngue produzido no curso foi elaborado pelos estudantes, visando ao trabalho comunitário, e foi revisado por professores indígenas e outros falantes das línguas rio-negrinas, contratados pontualmente para revisão de gramática e ortografia do material. 


\section{Temas transversais: território, cultura e política}

Neste capítulo detalhamos o tratamento dado aos temas território, cultura e política na primeira etapa formativa, visando não apenas evidenciar seu caráter transversal em todas as etapas formativas, mas também demonstrar os modos como eles foram trabalhados na construção de interfaces entre tais dimensões da cultura indígena e as atividades de vigilância em saúde a serem desenvolvidas pelos AIS. Também apresentamos as estratégias e exercícios implementados a fim de possibilitar uma melhor compreensão e reprodução em outros contextos de formação. Ao fim, apresentamos um conjunto de exercícios a serem desenvolvidos pelos agentes de saúde em cada um dos temas transversais. O tema cuidado não será explorado neste capítulo, pois, após a revisão da matriz curricular, optou-se por distribuir a sua abordagem nos tópicos desenvolvidos nas etapas formativas subsequentes.

\section{Eixo transversal Território}

Partimos de alguns pressupostos conceituais para iniciar a discussão. Primeiramente trabalhamos com o conceito de território, que, segundo Raffestin (1993), deve ser entendido como o produto de relações de poder travadas entre seus habitantes. Segundo o autor, o Estado é habitualmente visto como o principal agente produtor de territorialidades, mas, de fato, outros atores exercem e constroem territorialidades próprias, reconhecidas ou não pelo Estado, baseadas nas relações intergeracionais, de gênero e de etnia, sendo necessário também investigá-las a partir dos cotidianos. $A$ ação dos sujeitos institui, no território, relações entre os grupamentos humanos, com a exterioridade (humanos não indígenas, por exemplo) e com a alteridade. Essas dimensões, no caso das produções culturais indígenas, podem abranger animais, plantas e entidades supra-humanas, que criaram e habitam os mesmos territórios e, não raro, geram os recursos ali disponíveis. 
Dessa forma, a compreensão das territorialidades construídas cotidianamente no Alto Rio Negro implica perceber as terras indígenas para além de sua dimensão física, entendendo-as principalmente como um espaço social em que se instituem redes complexas que intermedeiam as estratégias necessárias para garantir a influência e o controle exercidos por um determinado grupo para permitir ou interditar o usufruto de bens e serviços no território (Raffestin, 1993). No contexto do curso, era importante perceber essa dinâmica para entender a maneira como os agentes de saúde se distribuem em determinados territórios (e em outros não) e as causas dessa distribuição, bem como as relações de poder, oriundas da estrutura de parentesco a que os AIS se vinculam e que pode oferecer apoio político ou obstaculizar-Ihes a atuação.

Monken e Barcellos (2005) afirmam que a territorialização é um dos pressupostos para a organização de processos de trabalho em saúde. Relembram, porém, que a abordagem habitual enfoca o território como o espaço de execução de ações de saúde em uma área previamente delimitada, mas que este supera, em muito, a dimensão político-administrativa da organização da atenção. Ali acontecem as interações da população e são ofertados serviços. O território tem um perfil próprio (epidemiológico, tecnológico, político, social e cultural) em permanente construção, e, principalmente, é o lócus das relações de poder que permeiam a vida social. Diante de tais características, o conhecimento do território e de suas particularidades é requisito essencial para o entendimento dos problemas de saúde da população, propiciando meios para planejar e executar intervenções capazes de potencializar as capacidades locais e reduzir os problemas de saúde. Com tais premissas sempre em foco, o conceito de território e suas aplicações transversalizou todas as fases do curso.

Entretanto, a literatura disponível no campo da saúde coletiva utiliza o termo de forma abrangente, comum a toda a sociedade ocidental, sem discutir mais profundamente as concepções particulares de território no âmbito das culturas indígenas. Por isso, buscou-se, primeiramente, apreender de que modo os próprios estudantes entendiam o assunto, uma vez que se trata de temática recorrente na produção mitológica rio-negrina. Nesses grupos, a distribuição espacial das diversas etnias e de seus segmentos internos influencia a ocupação dos ecossistemas e o acesso maior ou menor às terras cultiváveis, aos mananciais de pesca e a outros recursos de subsistência. Ou seja, a ideia de território, longe de ser algo desconhecido, é objeto de reflexão na vida cotidiana, tem espaço na cosmologia nativa e expressão prática na reprodução social dos grupos étnicos que ali vivem. Vale lembrar que, no caso das terras rio-negrinas, as famílias indígenas extraem diretamente da natureza, ou seja, do território que ocupam, os recursos necessários à subsistência, como a alimentação, meios de transporte e materiais necessários à construção das moradias. Em razão da 
importância do tema, a caracterização do território do ponto de vista indígena, seus limites, recursos e interfaces com a vida em sociedade foi desenvolvida na etapa inicial do curso e recuperada nas fases subsequentes do processo formativo.

À caracterização inicial dos territórios, seguiram-se a identificação e a descrição dos recursos disponíveis para garantir a reprodução social dos grupos, bem como os processos de trabalho rural que possibilitam a produção dos meios de subsistência. Por fim, discutiram-se o perfil demográfico da população residente, os problemas de saúde recorrentes e as estratégias capazes de superá-los.

Como um dos desdobramentos do tema território, examinou-se sua interface com a noção de saúde. No caso das etnias rio-negrinas, não foram encontradas ideias sistematizadas sobre o conceito de saúde nem palavras específicas para expressá-la. Os estudantes identificaram a noção de bem viver como aquela com maior proximidade com a de saúde.

A pergunta guia para explorar essa ideia foi: "O que precisamos para viver bem?". Com base na pergunta, os estudantes organizaram, na etapa de concentração, um debate entre eles que foi continuado na fase de dispersão, buscando a opinião de outros membros da comunidade a fim de responder à pergunta guia. A Figura 5 exemplifica uma das respostas obtidas na etapa de dispersão.

Figura 5 - Conceito de saúde do ponto de vista indígena

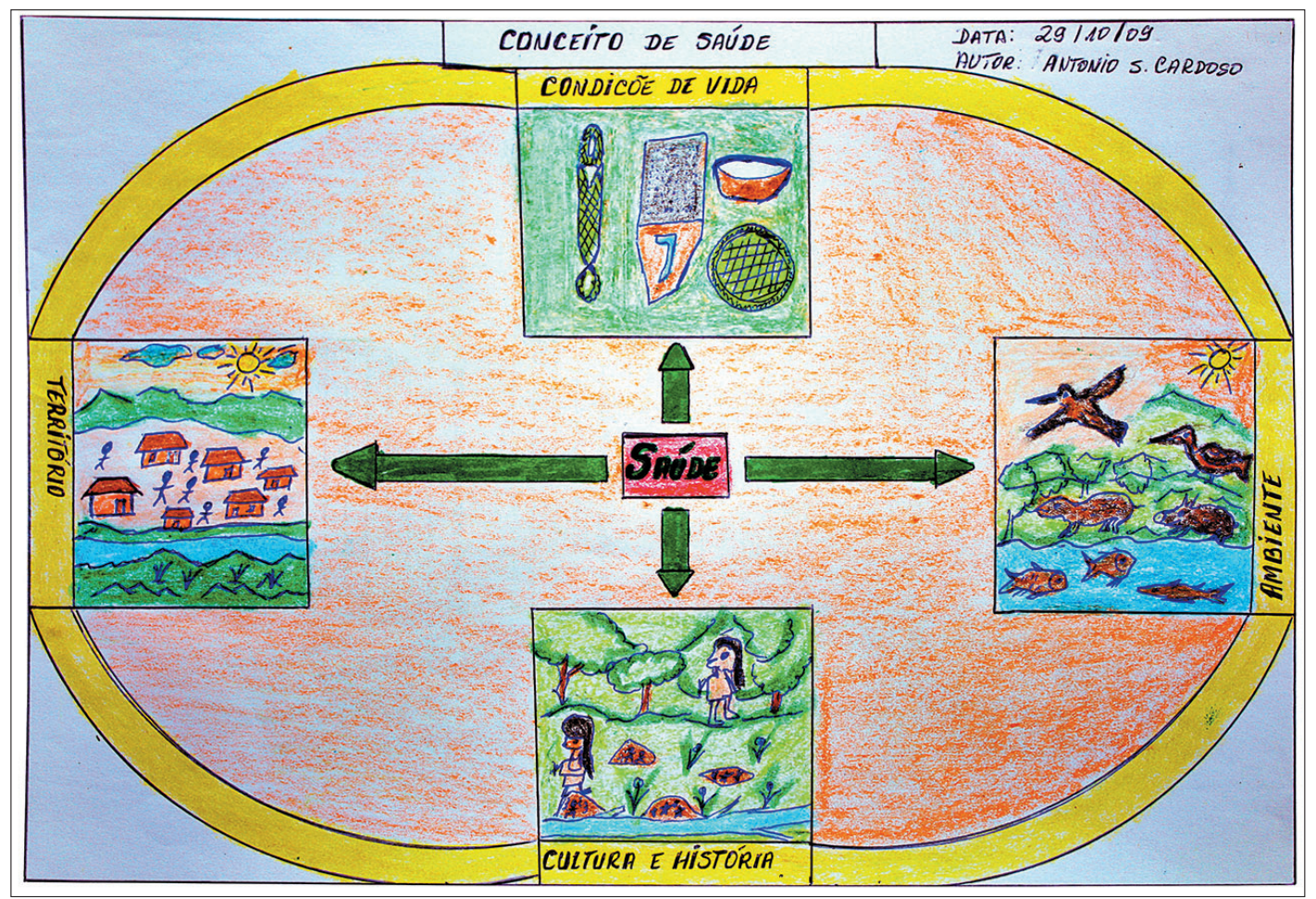

Acervo CTACIS (2009-20I5). 
A Figura 5 expressa a melhor aproximação obtida no curso para o conceito da saúde, entendido aqui como equivalente à terra indígena. No caso indígena, o território guarda equivalência com terra indígena, uma das principais bandeiras de luta do movimento indígena. No material produzido pelos estudantes, a terra surge como elemento primordial para garantir uma saúde de qualidade, pois a existência de um território definido e legalmente garantido com a demarcação é imprescindível para que se vislumbre um bem viver e se efetive a produção e reprodução material e simbólica da vida indígena. Para tanto, é necessário fiscalizar, monitorar e gerir o território e seus recursos, a fim de garantir os meios de existência.

A segunda dimensão na Figura 5, estreitamente interligada ao território, é o ambiente ou meio ambiente, entendido como o espaço do qual se extraem os meios que garantem a vida das pessoas. Fica evidente, para os estudantes do curso, que a retirada de meios de subsistência do ambiente implica não apenas uma ação material, mas também uma negociação com entidades não humanas, guardiães das plantas e animais, capazes de retaliar ações predatórias, produzindo doenças tradicionais. Em suma, a gestão do território/ambiente demanda o domínio do acervo de saberes sobre as terras, os cultivos, os mananciais de pesca, bem como de uma geografia mítica que aponta os locais de domínio dos seres espirituais, instituindo um conhecimento material e simbólico sobre o território e seus recursos.

Aqui se estabelece a interface entre território e dois elementos estruturais ao bem viver: a cultura e a história. No que diz respeito ao primeiro, tal interface já foi exemplificada. Quanto à história, reconhece-se como necessário ao bem viver o conhecimento das relações travadas com o mundo do branco, que influenciam decisivamente a transformação do cotidiano das famílias indígenas. A última dimensão, que aparece na Figura 5 sob o rótulo de condições de vida, remete aos processos de trabalho que permitem a produção dos alimentos e de outros meios de manutenção da vida cotidiana. A presença de elementos da cultura material, como peneira e tipiti, demonstra que tais condições de vida são reconhecidas pelos estudantes como produtos dos conhecimentos tradicionais (da cultura indígena, portanto) que garantem a reprodução social dos povos rionegrinos.

O mapeamento do território e seus recursos foi realizado, abrangendo os sujeitos sociais e as relações que travam entre si, a circulação de bens e serviços nesse espaço, os fluxos de pessoas e instituições, aí incluídos os fluxos de oferta de cuidados à saúde. Além dos conhecimentos tradicionais - muito detalhados - sobre a territorialidade indígena, foram utilizados conceitos e ferramentas da geografia, em que se incluíram noções de cartografia e de demografia, aprofundando o diálogo entre saberes científicos e tradicionais. 
Certamente essa abordagem foi inesperada para a maioria dos AIS, pois muitos deles já tinham participado de treinamentos anteriores em que a doença era a principal - por vezes única - premissa orientadora das capacitações.

As noções de território e territorialidades também foram utilizadas para analisar os modelos de atenção disponíveis nas terras indígenas e a organização dos processos de trabalho daí decorrentes. Tais discussões evidenciaram que, no âmbito do DSEl, o processo de trabalho mais perceptível e mais recorrente é aquele voltado para a remoção de casos de urgência, havendo carência de ações de promoção da saúde. Concluiu-se, então, ser necessário reorientar a atuação do agente de saúde para o desenvolvimento de ações de vigilância em saúde, tendo o território como eixo guia de seu trabalho, priorizando a identificação de problemas de saúde, os cuidados essenciais para abordálos e os fluxos percorridos para obtê-los - no território e fora dele -, os sujeitos e recursos básicos para lidar com tais necessidades conforme disposto no Quadro 3.

\section{Quadro 3 - Elementos para identificação de territorialidades}

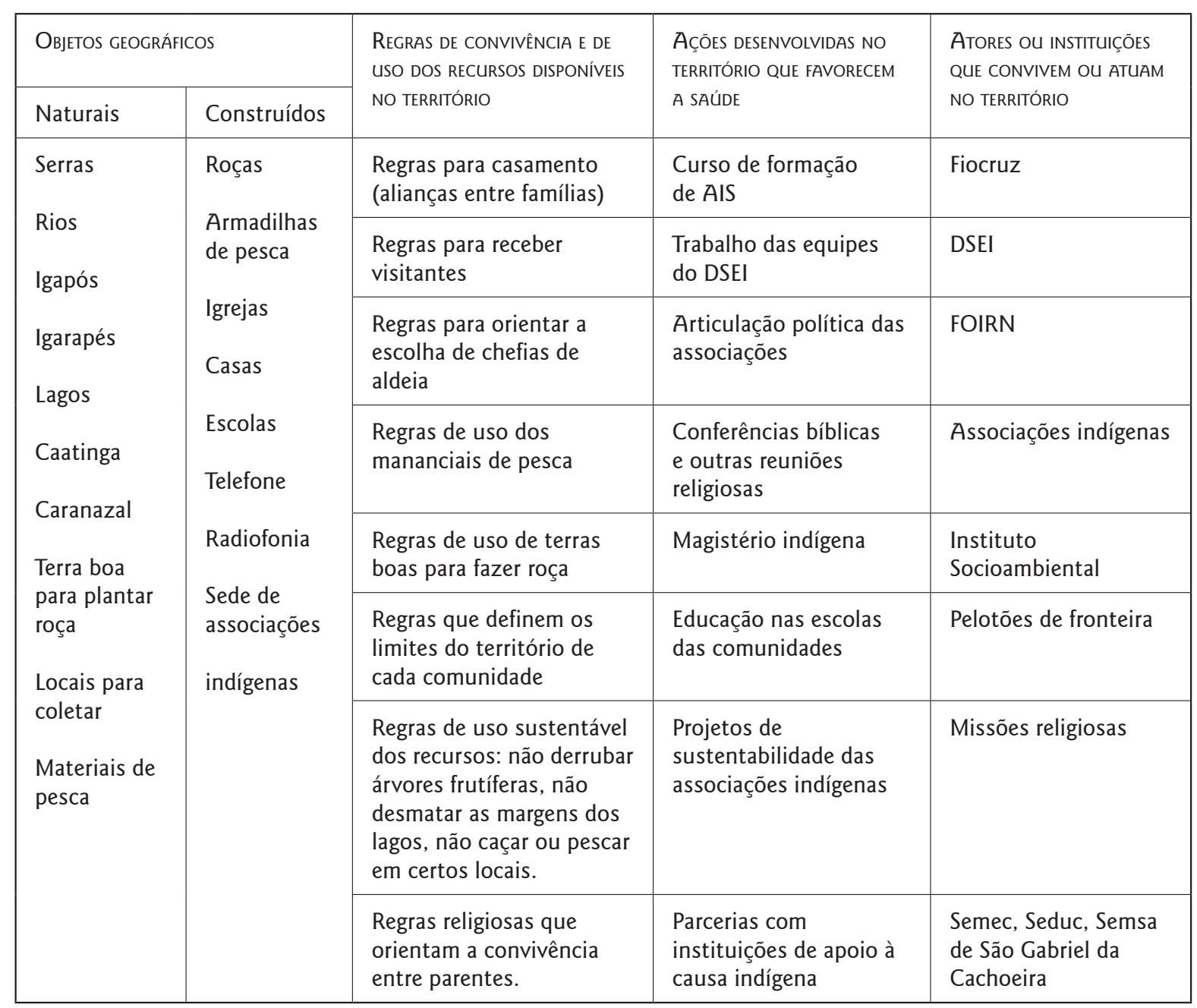

Acervo CTACIS (2009-20I5). 
Além da identificação de atores, fluxos e processos de territorialização, os estudantes tiveram acesso a noções de cartografia, tendo em vista a espacialização dos diversos territórios e seus recursos e a elaboração de mapas temáticos, conforme apresentado nas Figuras 6,7 e 8 .

Figura 6 - Mapa do território de abrangência de polo-base

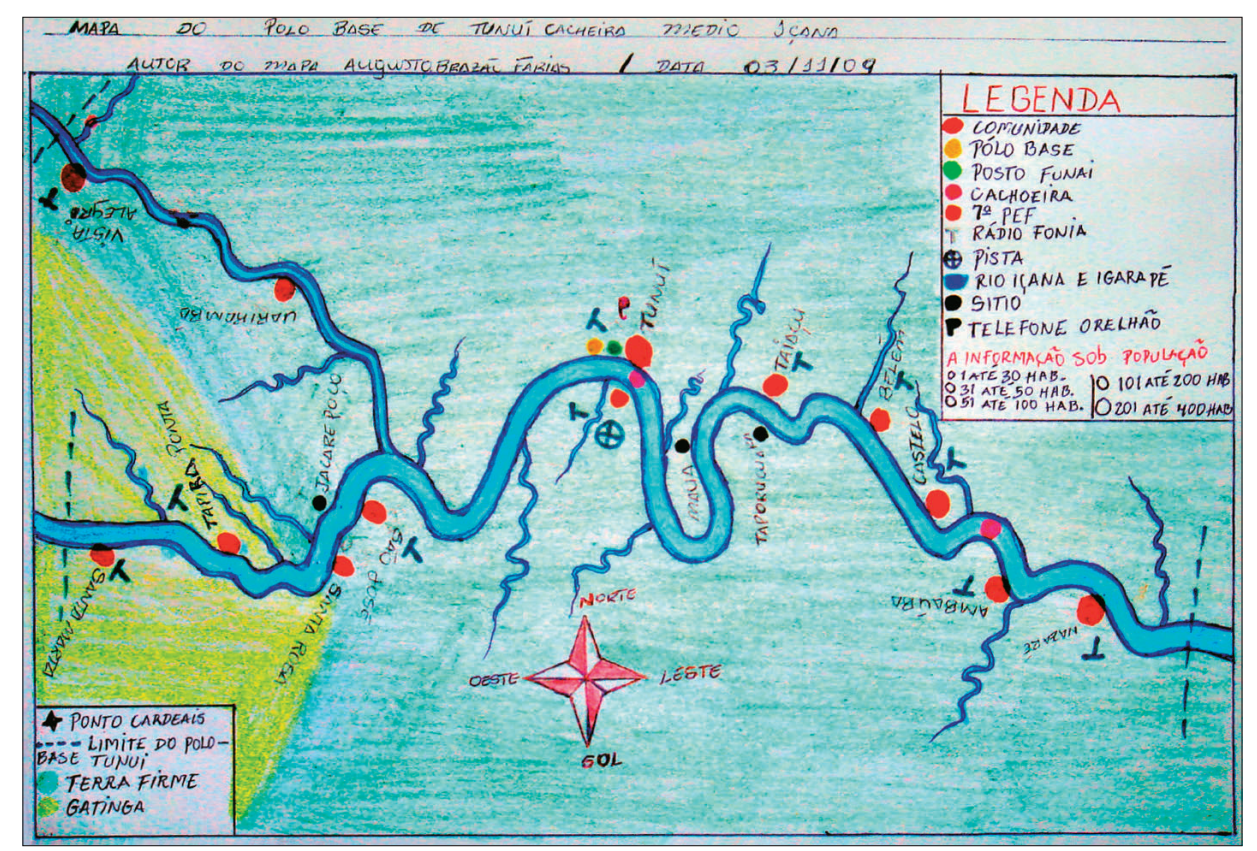

Acervo CTACIS (2009-20I5).

Figura 7 - Mapa de território de comunidade

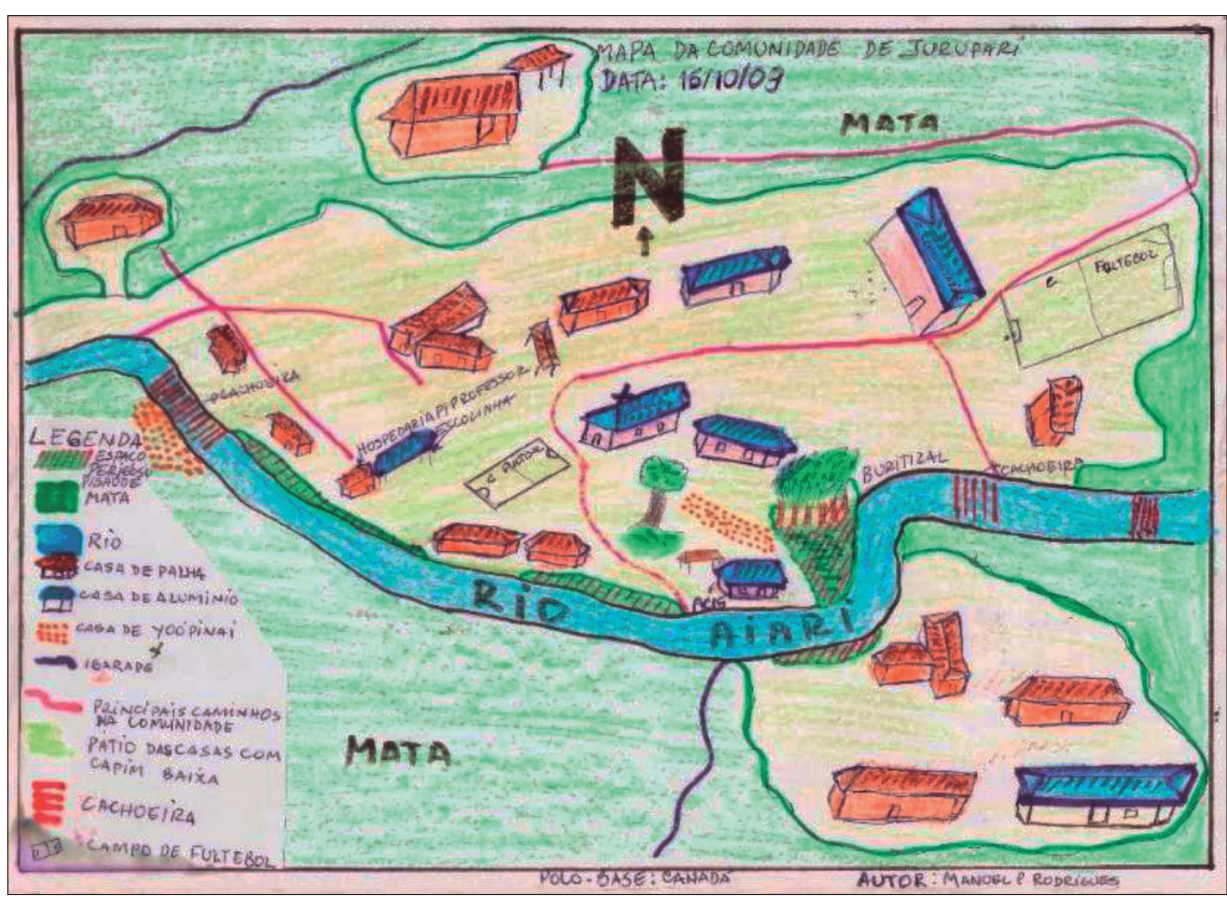

Acervo CTACIS (2009-20I5). 
Figura 8 - Tipos de solo no território de comunidade

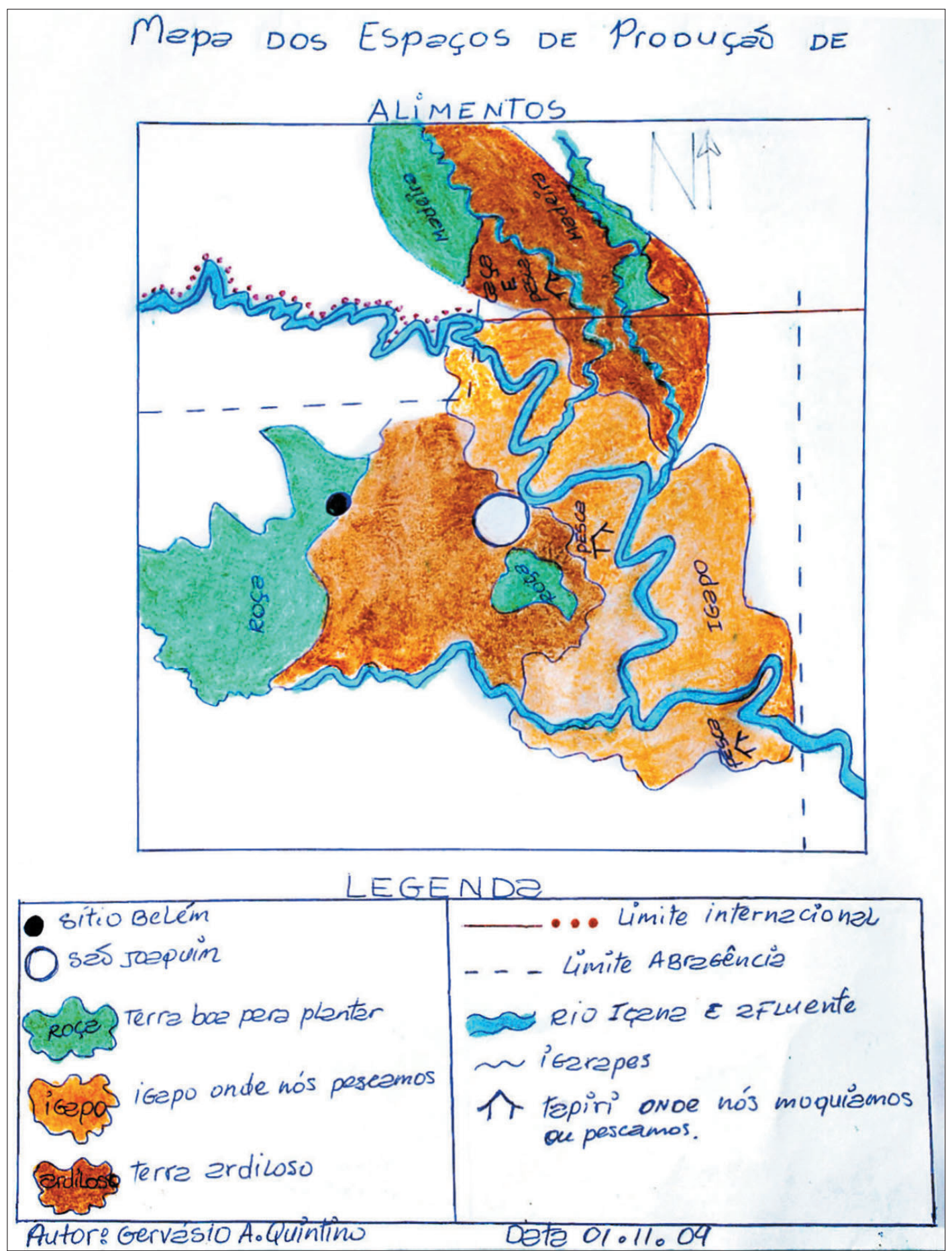

Acervo CTACIS (2009-20I5). 


\section{Figura 9 - Mapa de distribuição de yoópinai que causam doenças tradicionais}

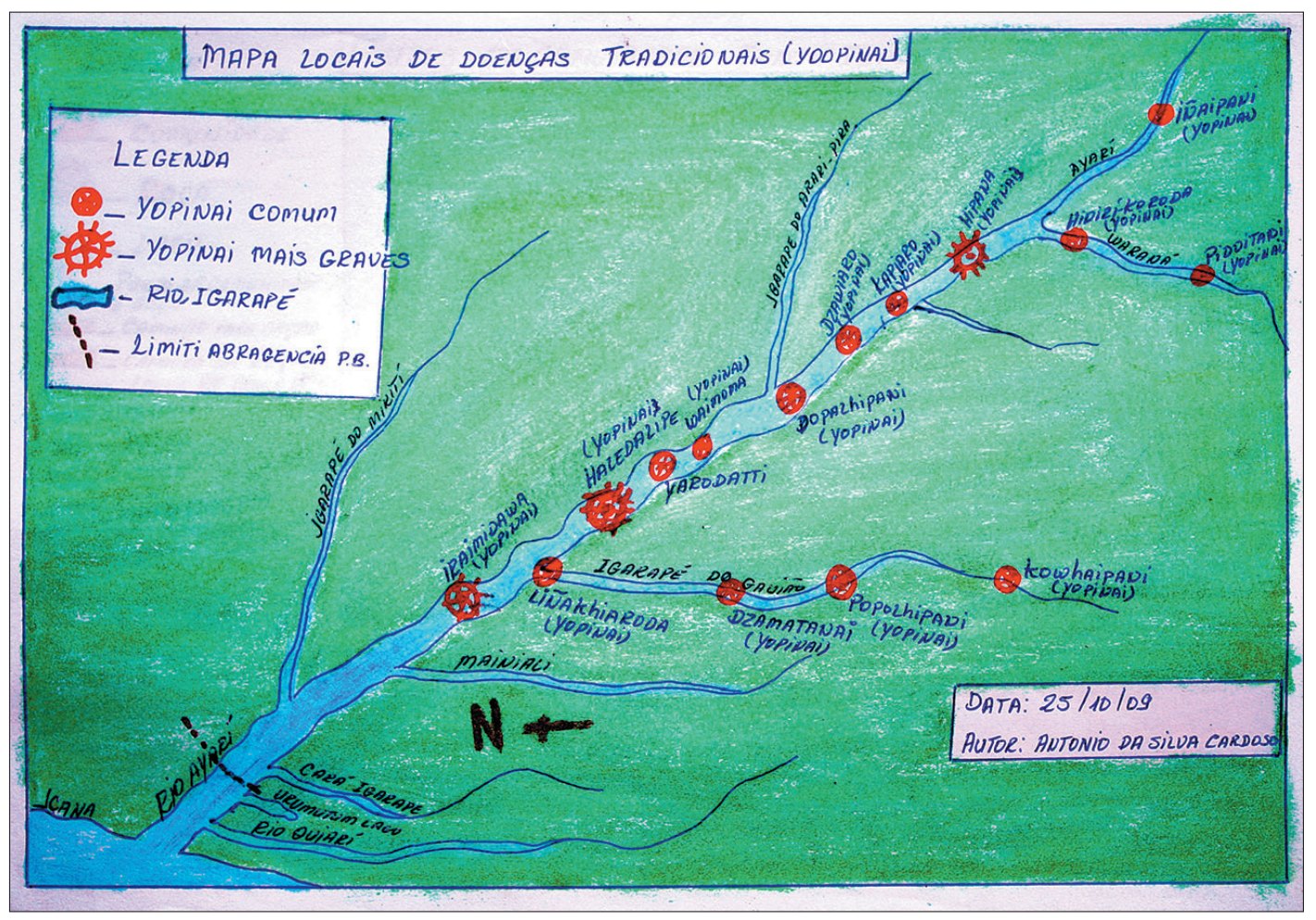

Acervo CTACIS (2009-2015).

As figuras apresentadas exemplificam algumas das dimensões exploradas nas discussões sobre território, no que diz respeito à organização de serviços (Figuras 6 e 7), à disponibilidade de recursos para produção de alimentos (Figura 8) ou aos locais considerados de risco para doenças tradicionais que resultam de agressões de seresespírito, em resposta a práticas predatórias humanas (Figura 9).

Tais mapas foram aprimorados na fase de dispersão mediante consulta a membros mais velhos e experientes das comunidades, conhecedores profundos das características do território de cada aldeia. Nas fases subsequentes do curso, as ilustrações foram resgatadas para orientar discussões sobre temas variados, cuja distribuição no território fosse passível de planejamento no rol de atividades dos agentes de saúde. Ou seja, na Etapa Formativa I foi desenvolvido um acervo de informações a ser utilizado nas etapas formativas subsequentes, mantendo-se, assim, a unidade e a articulação interna do processo ensino-aprendizado.

Ao trabalho com os mapas associou-se a aplicação de questionário, na etapa de dispersão, para coletar informações sobre as condições de vida nas aldeias de origem dos estudantes. Os principais tópicos tratados nesse levantamento versaram sobre alimentação, condições de moradia, transporte e fluxos percorridos pelos comunitários 
e equipes de saúde, situação de saúde nas aldeias, migração, escolaridade e renda, recursos sanitários do domicílio, problemas ambientais e satisfação ou insatisfação com as condições de vida. Os dados foram sistematizados e analisados juntamente com os estudantes em fases de concentração posteriores, operando como eixos de orientação, a fim de estabelecer prioridades na seleção de atribuições e competências dos egressos do curso para desenvolver atividades de vigilância em saúde.

A Figura 10 exemplifica outro produto do aprendizado sobre a dimensão humana do território: a população apresentada na forma de pirâmide demográfica. A elaboração das pirâmides demográficas visava não apenas identificar a população sob os cuidados da equipe de saúde, mas também subsidiar a futura vigilância de agravos recorrentes (como, por exemplo, a diarreia, que exige o acompanhamento das crianças em faixas etárias mais suscetíveis) e o cálculo de indicadores de incidência e prevalência, feito pelo próprio agente de saúde na comunidade.

Figura 10 - Pirâmide populacional de comunidade

\begin{tabular}{|c|c|c|c|}
\hline \multicolumn{4}{|c|}{ 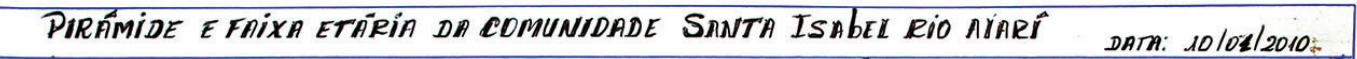 } \\
\hline \multicolumn{3}{|c|}{$\geq 70$ ANOS } & \multirow{2}{*}{$\square \square \square=3$} \\
\hline 65 ANOS & $A<70$ & ANOS & \\
\hline 60 ANOS & $A<65$ & ANOS & \\
\hline 55 ANOS & $A<60$ & $3=\square[$ & \\
\hline 50 ANOS & $A<55$ & $1=\square$ & $\square=1$ \\
\hline 45 ANOS & $A<50$ & $1=\square$ & i \\
\hline MO ANOS & $A<45$ & $2=\square$ & $\square=2$ \\
\hline 35 ANOS & $A<40$ & $3=\square \square \square$ & $\square \square \square=3$ \\
\hline 3OANOS & $A<35$ & ANOS & $\square \square \square=3$ \\
\hline 25ANOS & $A<30$ & $3=\square[$ & $\square \square=3$ \\
\hline 20ANOS & $A<25$ & $2=i$ & 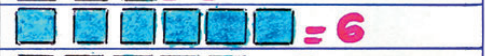 \\
\hline 15 ANOS & $A<20$ & $3=\square[$ & $0 \square \square \square=5$ \\
\hline 10 ANDS & $A<15$ & $4=\square \square I$ & 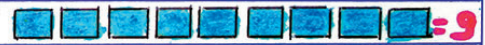 \\
\hline DSANOS & $A<10$ & $7 \square \square \square \square \square \square$ & Q⿴囗十口卄4 \\
\hline \multirow[t]{4}{*}{ OANOS } & $A<05$ & $s=\square \square \square \square \square$ & 回回回四田 \\
\hline & & $=36 \quad$ MULHERES & $=46$ HOMENS \\
\hline & & TRE POPUCACIONAL DA COMUNIDADE SANAF LSABELL & 82 PESSOAS. \\
\hline & & AUTOR: ANTÓ, & II DA SIIUA CARDOSO \\
\hline
\end{tabular}

Acervo CTACIS (2009-20I5).

Do ponto de vista dos estudantes, uma das ideias que permeou o processo de formação é que o território deve ser visto prioritariamente como espaço de produção da saúde, e não da doença. Ou seja, as ações a serem desenvolvidas na comunidade devem se pautar por aspectos muito mais amplos que o perfil de morbimortalidade vigente no território. 


\section{Eixo transversal Cultura}

$\mathrm{Na}$ seção anterior discutiu-se a interface entre o eixo transversal Território e certas facetas da cultura indígena. A abordagem adotada lançou mão da geografia política aplicada à saúde coletiva e dos conhecimentos tradicionais indígenas sobre os territórios em que os agentes de saúde vivem e atuam.

Entretanto, o eixo Cultura, concebido como tema que transversalizou a maioria das unidades pedagógicas, também foi desenvolvido com sucesso na discussão do processo saúde-doença-cura-cuidados, que articulou a valorização de saberes oriundos da tradição indígena com o aprendizado de técnicas e estratégias de atenção programática a problemas prioritários de saúde no território, adaptadas ao nível de competência do agente de saúde. Antes de relatar como ocorreu tal confluência, deve-se explicitar o marco teórico que orientou o desenvolvimento deste eixo.

O conceito de cultura adotado no curso se baseia em Geertz (2008), que entende a cultura como um sistema simbólico de valores que produz teias de significados sobre a vida social e material. Ao aplicar tal conceito à análise dos processos de doença, saúde e cura, torna-se necessário conhecer a forma como ele se produz e reproduz na interface entre os modos de vida indígena e as transformações históricas instituídas no processo colonizatório, dentre as quais se destaca o aparato médico-sanitário decorrente da implantação do Sasi e de seus respectivos DSEls.

Porém, a realização desse passo foi obstaculizada por um problema: a maioria dos ingressantes no curso era jovem e detinha pouco conhecimento dos saberes tradicionais sobre doença e cura, que são, além disso, temáticas mais afeitas aos especialistas nativos que às pessoas comuns da aldeia. Para contornar o problema, foram adotadas no curso duas estratégias principais: viabilizar a participação de especialistas indígenas conhecedores dos sistemas tradicionais de cura e cuidados de saúde de cada etnia; e estimular o ensino pela pesquisa, orientando os estudantes a buscarem, nas fases de dispersão, informações sobre o tema entre seus familiares e especialistas locais. Essa busca foi pautada pelo respeito aos limites impostos pelos especialistas entre as informações passíveis de circulação em domínio público e as que devem permanecer secretas, segundo os cânones de cada sociedade.

Entre as produções culturais de ampla circulação, os docentes indígenas narraram mitos de origem e meios de subsistência em cada etnia; memórias do contato interétnico; estrutura e relações de parentesco; sistemas de doença, cura e cuidados, bem como suas interfaces com a religiosidade indígena, a mitologia e a geografia nativa que reconhece 
um caráter espacializado da expressão das doenças tradicionais nos territórios indígenas. Na sequência do curso, a participação dos conhecedores das tradições indígenas se dirigiu à compreensão das fases de vida e cuidados adequados para cada uma delas, tal como recomendado na tradição nativa, temas particularmente relevantes nos módulos relativos à saúde da criança e da mulher.

Habitualmente esses participantes se comunicavam na própria língua nativa e suas informações eram traduzidas pelos alunos. Os materiais educativos dela decorrentes eram traduzidos pelos alunos a fim de que os docentes falantes de português pudessem acompanhar o desenvolvimento dos conteúdos, efetuando-se, quando necessário, a correção das traduções pelos pares. No intuito de potencializar as estratégias de ensino pela pesquisa, foram trabalhadas no curso noções gerais de etnografia, técnicas de entrevistas e de redação de relatórios simplificados de pesquisa. Os estudantes elaboraram detalhadas etnografias de processos de trabalho que garantem a reprodução física e social das famílias, entendidos como parte integrante da caracterização do bem viver (Figura 5). Além da elaboração de textos, os estudantes também foram incentivados a produzir materiais visuais, principalmente cartazes, tendo em vista 0 trabalho educativo a ser desenvolvido na comunidade. A apresentação dos textos e cartazes também proporcionou subsídios para avaliação do aprendizado dos temas abordados em cada etapa formativa.

\section{Eixo transversal Política}

O eixo Política teve variados objetivos pedagógicos. Aqui serão destacadas a discussão sobre a atuação do movimento indígena no território e a contextualização de eventos que propiciaram a emergência da política de saúde indígena.

O trabalho pedagógico se pautou pela ênfase nas conquistas obtidas no campo da saúde como produto de agência indígena e da capacidade de angariar alianças com outros setores no cenário político brasileiro.

Do ponto de vista didático, o eixo foi organizado de maneira a incentivar a reflexão dos estudantes sobre as características de atuação do movimento indígena e suas consequências na vida prática das pessoas, bem como a inserção dos AIS em mobilizações mais amplas pelos direitos indígenas, para além da pauta da saúde. Com esse foco, abordamos temas como política indígena e políticas indigenistas, organização das políticas de saúde no Brasil, políticas de educação, políticas afirmativas e, por fim, benefícios sociais e políticas de inclusão étnico-racial. O tratamento desses temas se distribuiu transversalmente ao longo das três etapas formativas. 
Na primeira etapa, o trabalho com o eixo Política iniciou com a participação de lideranças etnopolíticas que falaram sobre a atuação do movimento indígena na região do Rio Negro. A discussão abrangeu temas como demarcação das terras indígenas do Rio Negro, realizada pela FOIRN e suas associações de base, em iniciativas de sustentabilidade e geração de renda, valorização dos modos indígenas de viver, implantação de escolas interculturais indígenas, contratação, capacitação e valorização dos AIS. Essa dinâmica propiciou a colaboração de estudantes com participação pregressa no movimento indígena, que também narraram suas experiências. A própria realização do curso de AIS foi enfocada como um dos produtos da militância indígena. Paralelamente, o corpo docente correlacionou o avanço obtido no acesso aos direitos étnicos com acontecimentos históricos e processos variados de luta pelos direitos civis no país. A atividade visava demonstrar interfaces entre conquistas e retrocessos da política indigenista com a dinâmica de atuação da sociedade civil brasileira, na busca de melhoria das condições de vida e saúde.

A necessidade de aproximar esses aspectos gerais da vida política com o campo da saúde, entendido como um tipo de política setorial, dependente do cenário mais geral das políticas sociais, levou à discussão da história dos movimentos pela melhoria da saúde, com destaque para a Reforma Sanitária e as lutas pela construção do SUS. Também foi abordada a trajetória constitutiva da organização das instâncias de controle social, bem como de políticas específicas, como as de atenção básica, de saúde da criança e da mulher.

Esse eixo se apoiou fortemente, como estratégia pedagógica, nas narrativas orais dos agentes políticos indígenas. Há bastante material impresso sobre as lutas sociais e sanitárias do mundo não indígena, mas é escassa a publicação sobre os movimentos indígenas. Esse fato direcionou o processo pedagógico para o resgate de história oral, tomando-se os depoimentos das lideranças indígenas presentes nas diversas fases do curso. Além disso, os estudantes foram estimulados a efetuar o registro, com base em depoimentos colhidos em suas próprias comunidades, da história das organizações indígenas locais, das lutas pela educação indígena em cada grupo étnico rio-negrino, bem como das vivências familiares do processo de demarcação de terras. Também foram consultados documentos e outras fontes locais, não publicadas.

As atividades prosseguiram com a produção de textos curtos versando sobre a temática. Além de contribuir para sistematizar o registro da memória oral rio-negrina sobre seus principais eventos políticos, a leitura, interpretação e redação de textos também operou como estratégia pedagógica voltada para ampliar o domínio do português, a segunda língua nas terras indígenas rionegrinas. Outro produto interessante foi a ela- 
boração, em cada polo, de um conjunto de linhas do tempo, usando a memória dos mais velhos como fonte de informação. Essa atividade evidenciou com muita clareza as características da mudança sociocultural que vem ocorrendo entre os diversos grupos étnicos participantes do curso. Adotou-se também, com ampla aceitação pelos estudantes, a projeção - seguida de debates - de vídeos produzidos por entidades e cineastas indígenas sobre temas variados, tais como: lutas na Constituinte de 1988; dinâmica das associações indígenas; política ambiental e os grandes projetos desenvolvimentistas que ameaçam a população indígena (como a construção de hidrelétricas); e situações de violência a que esses povos estão sujeitos.

As discussões travadas neste eixo incentivaram a inclusão de agendas etnopolíticas na organização do trabalho rotineiro do AIS, estimulando uma atuação proativa no aprimoramento das ações do DSEl. Além disso, problematizaram a inserção desse profissional nas equipes multidisciplinares de saúde indígena que atuam no DSEI, destacando a necessidade de superação dos papéis de logístico e de tradutor que the vêm sendo atribuídos após a implantação do Sasi. Além das dimensões institucionais, a discussão abrangeu a busca de reconhecimento profissional da categoria agente de saúde no SUS, bem como a atuação de suas entidades representativas, como a Federação e Confederação de Agentes Comunitários de Saúde. Dentre os objetivos da atividade, buscava-se o reconhecimento de pontos de interesse comuns entre agentes comunitários indígenas e não indígenas.

Na sequência, retomou-se o conceito de saúde enunciado espontaneamente pelos indígenas no início do curso, correlacionando-o com a temática trabalhada neste eixo formativo. A discussão propiciou o reconhecimento de que as condições de saúde se ligavam indissoluvelmente às condições de vida das pessoas. O passo seguinte, conduzido pelos docentes, foi associar esta noção à de determinantes sociais da saúde.

O diagrama de Dahlgren e Whitehead (199I) foi, então, apresentado e explicado para os estudantes (Figura II). Entretanto, eles não se identificaram com os elementos constitutivos desse diagrama, pois espelhavam condições urbanas de vida e, por isso, não foram reconhecidos como significativos no mundo indígena. 
Figura 1 I - Diagrama dos determinantes sociais da saúde

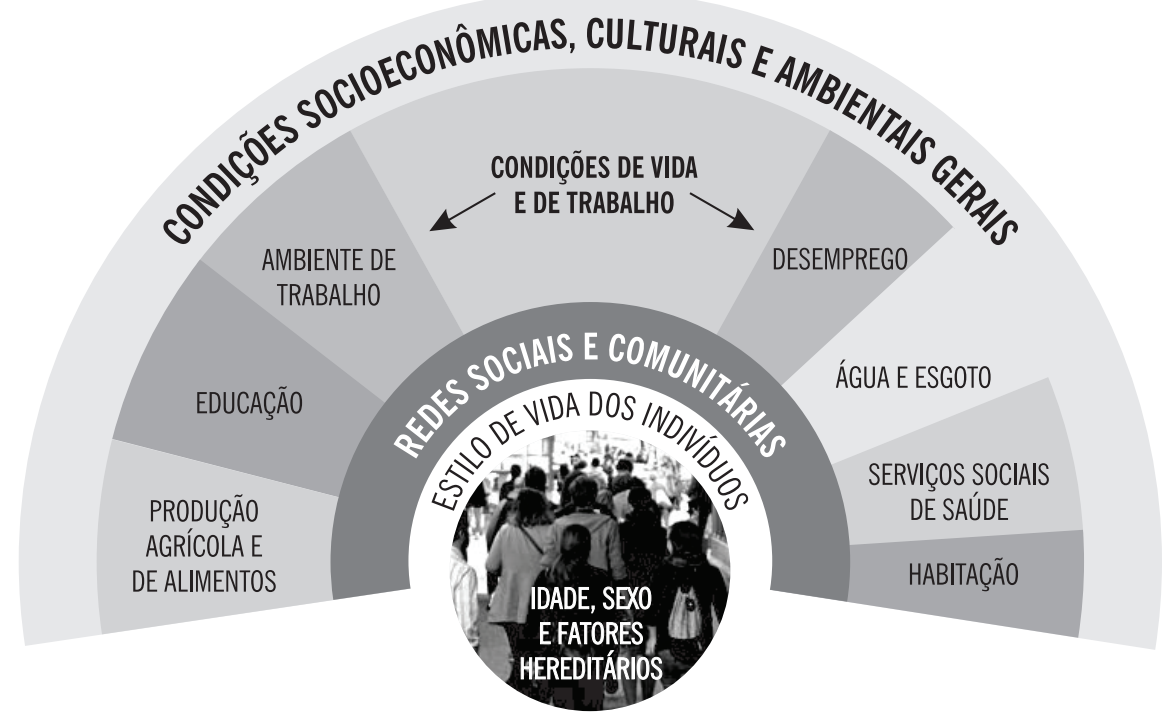

Fonte: Dahlgren E Whitehead, I99I.

Uma vez compreendido o sentido do diagrama, passou-se ao exercício de reconstruílo com elementos que traduzissem condições capazes de influenciar os níveis de saúde e que fossem congruentes com o modo indígena de viver. Os estudantes trabalharam em grupo, e o resultado pode ser observado na Figura 12.

Figura 12 - Diagrama de determinantes sociais da saúde adaptado para a população indígena

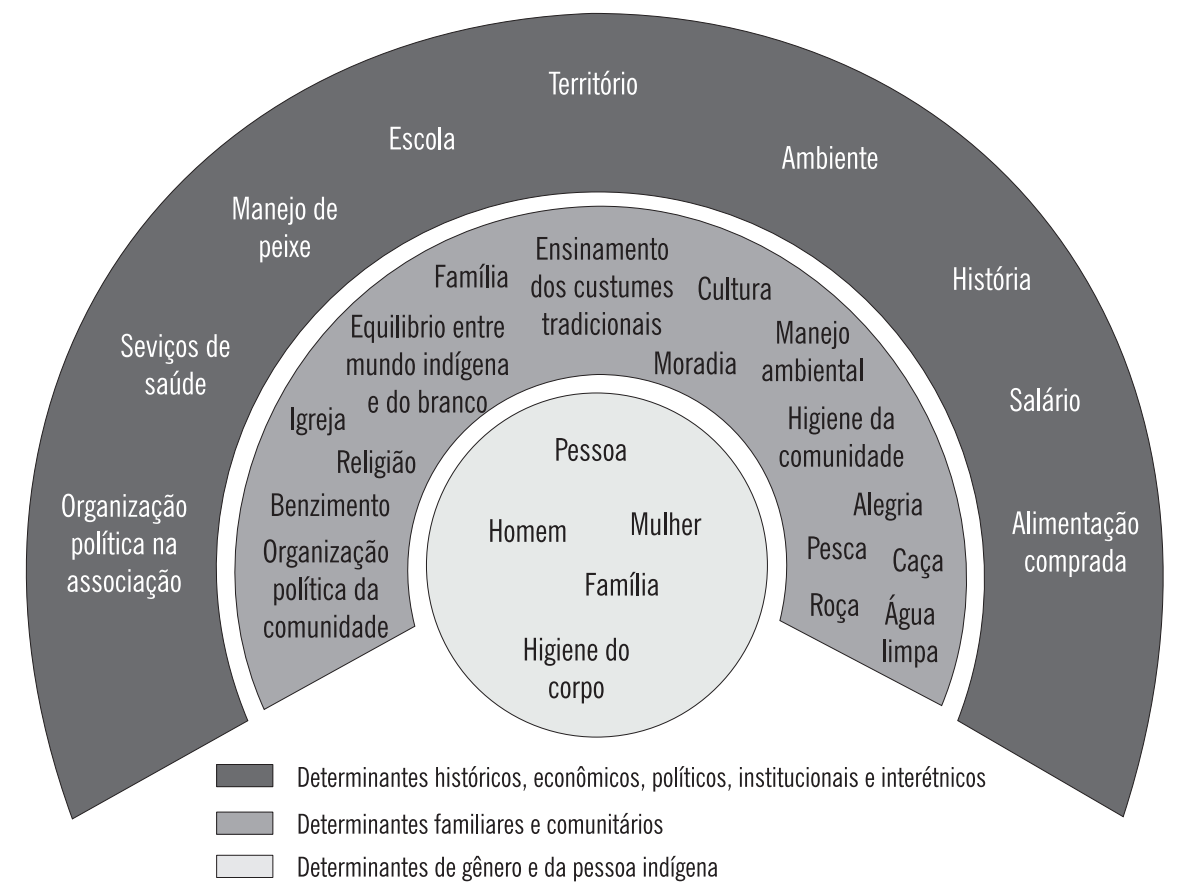

Acervo CTACIS (2009-2015). 
O modelo elaborado pelos estudantes apresenta diferenças consideráveis, em comparação ao de Dahlgren e Whitehead ( 199 |). No círculo mais central, os elementos que indicam determinação biológica (sexo, idade e herança genética) na figura original são substituídos por categorias socialmente produzidas (gênero e laços de parentesco). É algo congruente com a concepção nativa rio-negrina, que prioriza o grupo de parentes, $e$ não o indivíduo, que enfatiza os fatores sociais, e não os biológicos e anatômicos, como determinantes da doença. Do mesmo modo, se explica a presença da higiene do corpo como elemento central no diagrama. Nas culturas daquela região, a limpeza rigorosa dos corpos é considerada fundamental na preservação da saúde, uma vez que maus odores corporais são atraentes para os animais-espíritos cuja agressão é capaz de provocar doenças nos humanos. Raciocínio similar também pode ser utilizado para analisar os elementos constitutivos dos círculos mais amplos de determinação do processo saúdedoença, de acordo com a versão indígena. A conclusão mais importante desse exercício de reconstrução do diagrama é que é necessário ter sensibilidade para compreender que noções e variáveis de determinação social da saúde e da doença não são universais, podendo variar culturalmente.

O desenvolvimento dos temas transversais Território, Cultura e Política possibilitou a criação de um acervo de conhecimentos que transversalizou todos os demais. O desenvolvimento dessas noções, apoiadas simultaneamente nos saberes nativos e científicos, permitiu não somente demonstrar interrelações entre as condições de vida, organização do cuidado, políticas sociais e de saúde, bem como aplicar essas concepções ao cotidiano das famílias, por meio de ações de saúde com destacada participação dos AIS. Além disso, o desenvolvimento do processo pedagógico levou-nos a concluir que é factível replicar o processo em outros contextos indígenas. Será preciso, porém, levar em conta a potencialidade das especificidades locais como ferramenta enriquecedora das discussões a serem travadas em outros territórios indígenas.

As atividades também propiciaram subsídios para que os AIS pudessem perceber a necessidade, e a importância, de deter o máximo de dados sobre seu território de atuação e de utilizar tais informações para efetuar o planejamento de ações a serem desenvolvidas no território. São diretivas que coincidem com o conceito de vigilância em saúde, desenvolvido em etapas posteriores do curso, e que operou como eixo orientador do novo perfil de atuação desenhado pelo processo formativo.

O interesse dos AIS em manter uma participação qualificada em fóruns de discussão do movimento indígena comprova o reconhecimento dos estudantes da importância das discussões travadas neste eixo formativo. Nos fóruns, lutaram pela inclusão da pauta da saúde indígena, uma vez que temas como demarcação de terras e lutas por direitos 
étnicos habitualmente ocupam a maior parte da agenda das entidades. Ao final do curso, cabe destacar a organização de uma assembleia congregando os novos técnicos em agentes indígenas de saúde para criar uma associação dos agentes indígenas de saúde do Rio Negro, com o objetivo de desenvolver lutas de reconhecimento de sua categoria profissional e de aprimorar a organização dos processos de trabalho do DSEl, buscando valorizar o trabalho dos AIS.

Na sequência são apresentados alguns exemplos dos exercícios realizados pelos AIS para o desenvolvimento de ações de ensino pela pesquisa.

Exercícios desenvolvidos nos eixos formativos Território, Cultura e Política

EXEMPLO I: TÉCNICAS DE COLETA DE DADOS POR MEIO DE ENTREVISTAS

I) Entrevista

Entrevistado ou informante é a pessoa que responde à entrevista.

Entrevistador é aquele que faz as perguntas e registra as respostas.

- Recomendações para realizar uma boa entrevista:

I. Ao chegar à casa do informante, você deve se apresentar, explicar o objetivo do trabalho e por que ele precisa responder às perguntas que constam no questionário ou roteiro de entrevista.

2. O informante pode estar ocupado e não querer responder à entrevista naquele momento. Caso isso aconteça, procure marcar a conversa para outro horário em que o entrevistado esteja disponível.

3. Uma entrevista sempre deve estar identificada. No registro a ser feito, deve-se informar quem é o entrevistador e quem é o entrevistado. Para o entrevistador, coloque seu nome. Para o entrevistado, informe: nome, idade, comunidade e etnia. Em algumas entrevistas, não se pede o nome do entrevistado. Então, leia com atenção o roteiro que orienta a coleta de dados e verifique se está sendo solicitado o nome do entrevistado.

4. Seja atencioso e respeitoso com o entrevistado. Não critique, não censure e não faça piadas sobre ele ou sobre o que ele disser. Seja paciente. Quando o entrevistado não entender o sentido das perguntas, repita devagar o teor das perguntas até que ele entenda bem o que está sendo perguntado. 
5. Sempre que possível, procure fazer a entrevista num local calmo e silencioso para garantir que o trabalho seja bem feito. Se possível, também faça as perguntas na língua indígena do entrevistado para facilitar o entendimento.

6. Escute o entrevistado com atenção e tome cuidado para não interromper a fala dele. Se tiver dúvidas, anote suas dúvidas para perguntar depois.

7. Não responda pelo entrevistado. Anote exatamente as respostas que ele der.

8. Não comente com outras pessoas as informações dadas pelo entrevistado. O AIS deve respeitar os informantes e não deve fazer fofoca sobre o que the foi dito.

EXEMPLO 2

II) Roteiro para elaboração de etnografia de processos produtivos e identificação de agravos associados

I. Nome e etnia do autor da etnografia.

2. Data da coleta dos dados.

3. Tema estudado: confecção de beiju.

4. Identificação do informante: nome, idade, sexo, comunidade e etnia.

5. Como coletar e apresentar os dados:

5.I. Você precisará descrever todos os passos necessários para a confecção do beiju. Lembre-se que essa tarefa envolve trabalho masculino (parte do trabalho de roça) e feminino (plantar a mandioca, limpar a roça, extrair e transportar a mandioca até a casa, pubar, descascar, ralar, tipicar, secar e assar o beiju. Fazer beiju é um complexo processo que envolve muitas tarefas; então você precisará dividir a tarefa de coleta e registro dos dados em pequenas etnografias de cada fase do trabalho.

5.2. Para o exercício não ficar muito longo, este roteiro tomará como exemplo apenas a fase de ralar a mandioca, que é uma tarefa feminina. Entretanto, os procedimentos que você precisará seguir para coletar, organizar e apresentar os dados poderão ser utilizados também para descrever as demais fases do trabalho da confecção do beiju, bem como para realizar etnografias sobre outros temas de pesquisa. 
5.3 Lembre-se de que fazer beiju é um tipo de trabalho que exige uma sequência predeterminada. Por isso, você deve prestar bastante atenção aos passos necessários para finalizar o trabalho e fazer um registro fiel, seguindo a mesma ordem do relato do informante.

5.4. A seguir, damos exemplo de uma sequência de tarefas necessárias para confeccionar o beiju. Lembre-se que o objetivo dessa sequência é auxiliar na coleta de dados. Ela não substitui sua descrição de cada fase do trabalho:

- Conte como faz para percorrer o caminho entre a casa dela e a roça.

- Descreva o que faz ao chegar à roça, pedindo mais detalhes sobre o trabalho de retirada da mandioca.

- Descreva como faz para transportar a mandioca até a casa dela.

- Descreva o processo de descascar, lavar, colocar de molho, ralar, misturar mandioca dura e mole, passar no tipiti, tirar tucupi, tirar goma, peneirar a massa até ficar pronta para fazer o beiju.

5.5. A coleta dos dados pode ser feita por meio de perguntas dirigidas à informante (técnica de entrevista), mas uma alternativa melhor é observar diretamente a realização do trabalho. Nesse caso, você pode utilizar o roteiro aqui sugerido para guiar a observação.

6. Liste todos os materiais usados pela informante para fazer o beiju.

7. Registre o tempo gasto para concluir a fase do processo produtivo que está sendo pesquisando. 


\section{4 \\ Cuidado e vigilância alimentar e nutricional em terra indígena}

A versão de 201 I da Política Nacional Alimentar e Nutricional (Pnan) descreve um cenário alimentar e nutricional no Brasil marcado pela ampliação do acesso aos alimentos e redução expressiva da desnutrição. Esta teria deixado de representar um problema de saúde pública, substituída pelo aumento da obesidade em todas as camadas da população (Brasil, 20I I). Porém, o mesmo documento reconhece que tal perfil não se aplica às populações indígenas, com $26 \%$ de desnutrição, a outras minorias étnicoraciais, como quilombolas, com 16\% de desnutridos, e a residentes em áreas rurais da Amazônia, com 15\%, apresentando elevadas prevalências de desnutrição crônica, em particular entre as crianças de 0 a 4 anos (Brasil, 201 I).

No contexto indígena, a vigilância nutricional se mantém como ponto de relevância no conjunto de ações a serem priorizadas pelo subsistema de saúde indígena. Coimbra e colaboradores (2013) disponibilizam dados que apontam grave comprometimento de níveis nutricionais de crianças de 0 a 5 anos, que apresentam baixa estatura e baixo peso para a idade, concomitantemente à alta prevalência de anemia entre mulheres indígenas (Borges et al., 20 I 5), o que contribui para a persistência de déficit nutricional agudo e crônico.

No DSEl, onde o curso CTACIS foi oferecido, as ações desenvolvidas pelas equipes multidisciplinares de saúde indígena são articuladas com o Sisvan. Nesse DSEl as ações do Sisvan realizadas nas aldeias são, geralmente, delegadas à equipe de enfermagem encarregada de pesar, medir e registrar periodicamente tais dados nos mapas de acompanhamento. Sendo o Sisvan um sistema de diagnóstico e monitoramento da situação nutricional, uma vez constatada a condição de baixo ou muito baixo peso e/ou baixa estatura para a idade, as práticas das equipes de saúde indígena seguem um padrão rotineiro de oferta de suplementação alimentar com leite em pó para os lactentes, adicionado a outros itens, como óleo de cozinha e arroz, milho ou outros carboidratos, para as crianças mais velhas. 
Ao longo de sua trajetória, tanto a Pnan quanto o Sisvan têm sido criticados por suas limitações. Historicamente um dos componentes mais discutidos foi a Estratégia Nacional para Alimentação Complementar Saudável (Enpacs), que tem entre seus objetivos promover orientações alimentares para crianças usuárias da rede de atenção básica. As questões levantadas com relação à Enpacs giravam em torno da limitação do aconselhamento a um conjunto restrito de padrões alimentares e da ausência de estratégias que permitam reconhecer as culturas alimentares dos usuários do sistema de saúde, necessariamente múltiplas num país como o Brasil (Coelho et al., 2015; Camilo et al., 20II).

Além do necessário respeito à diversidade cultural, uma política alimentar e nutricional bem-sucedida precisa se reconhecer como ação integral e intersetorial na medida em que a persistência da desnutrição está ligada às desigualdades sociais e econômicas que geram situações diferenciadas de risco alimentar. A implementação dessas políticas exige um reconhecimento adequado das situações de saúde vigentes no território de abrangência das equipes de saúde, o que não ocorre quando a atuação dos profissionais se limita ao diagnóstico biológico sem o devido reconhecimento das condições de vida no território (Coelho et al., 20 I 5; Camilo et al., 20I I). Por sua vez, a versão mais recente da Pnan mostra preocupação com a diversidade cultural e alimentar, visto que preconiza ações que promovam o respeito, a preservação e o resgate das práticas e culturas alimentares da população (Brasil, 20 I I).

As críticas ao Sisvan giram principalmente em torno de sua dificuldade em alcançar amplas coberturas e garantir continuidade no monitoramento dos indicadores nutricionais, além do fato de que os dados nele produzidos não vêm sendo usados para orientar a tomada de decisão no planejamento de ações nas instituições de saúde (Camilo et al., 20I I). Em que pese a existência de ressalvas à operacionalização do Sisvan, este permanece reconhecido como uma ferramenta útil para monitorar indicadores nutricionais e reduzir a morbimortalidade infantil, recomendando-se a superação de seus limites por meio do aprimoramento da qualidade e regularidade de suas ações e da qualificação dos profissionais que as executam (Pedraza, 20I6). Outros autores também reconhecem o Sisvan como uma ferramenta que possibilita realizar vigilância alimentar e nutricional na atenção básica e gerar informações sobre o perfil alimentar e nutricional de crianças atendidas, orientando a tomada de decisão sobre os cuidados adequados à cada situação.

Em tais circunstâncias, o propósito de qualificar a força de trabalho dos AIS, profissionais cuja permanência nas aldeias é garantida, deve ser visto como via de obtenção de registros regulares que permitam construir um perfil nutricional consistente 
da população usuária dos serviços do subsistema de saúde indígena, capaz de orientar a oferta adequada de cuidados.

Outro elemento fundamental das atividades de atenção básica de saúde é a caderneta de saúde da criança. Pedraza (2016) empreendeu uma ampla revisão da literatura, na qual verificou sua recorrente subutilização. $O$ autor recomenda zelo no registro adequado da curva de crescimento no cartão da criança e a utilização desses resultados para efetuar orientações requeridas em caso de déficit nutricional. Tais medidas são reconhecidas como um modo prático e factível para dar visibilidade à situação nutricional, identificar e classificar situações de risco entre as crianças atendidas (Pedraza, 20l6).

A sensibilidade aos padrões alimentares das populações sob risco nutricional é fator crucial para a instalação ou restauração de uma dieta saudável, acessível e congruente com as culturas e valores das famílias. No caso indígena em particular, as ações habitualmente realizadas para suplementar a alimentação albergam um indissolúvel componente etnocêntrico que precisa ser problematizado, para evitar que as medidas preconizadas incrementem a agressão cultural a que os povos indígenas vêm sendo historicamente submetidos. As atividades programadas para o tema alimentação e nutrição no curso de formação técnica profissionalizante dos AIS buscaram superar os limites apontados na literatura, como as falhas na implementação do Sisvan e o caráter etnocêntrico da política de suplementação alimentar adotada no país.

Para tal fim foram adotados como eixos-guia da formação o respeito à diversidade alimentar inerente às culturas indígenas e o compromisso com a qualificação dos estudantes para efetivar a vigilância nutricional, tanto em nível coletivo quanto individual. Essas escolhas pedagógicas favorecerem a capacitação simultânea para efetivar o monitoramento epidemiológico e a orientação alimentar, necessários à reversão de agravos identificados.

No caso específico da terra indígena Alto Rio Negro, o ingresso de alimentos ultraprocessados já é corrente na dieta das famílias, mas boa parte do aporte alimentar provém do plantio de roças e punção de alimentos na mata e nos ambientes aquáticos. Essa circunstância favorece a valorização do conhecimento indígena sobre o território e suas fontes de alimentos, bem como a preservação das práticas culinárias e alimentares tradicionais, que possibilitam uma abordagem culturalmente sensível da temática da alimentação. Além disso, tal contexto favorece a articulação entre os eixos formativos Cultura, Território e Política que transversalizaram o processo formador dos AIS.

A atuação dos AIS também foi valorizada para superar um dos problemas recorrentes no DSEl onde se realiza o curso, que é a descontinuidade da presença dos demais 
profissionais das Emsis nas aldeias. Tal descontinuidade inviabiliza tanto a tomada regular de medidas antropométricas da população monitorada quanto a avaliação sistemática de progresso do agravo nutricional ou de sua redução. $A$ atuação cotidiana dos AIS foi entendida como vantajosa para a superação dessa dificuldade, ressalvandose o fato de que, no período precedente ao processo formador, esses agentes não tinham qualquer protagonismo nas atividades de monitoramento e avaliação nutricional realizadas no DSEI.

A programação das atividades formativas seguiu as linhas de ação preconizadas pela Pnan das quais foram desenvolvidos os seguintes itens no processo formador: organização da atenção nutricional, no âmbito de competência do técnico de nível médio; promoção da alimentação adequada e saudável; vigilância alimentar e nutricional; participação comunitária e qualificação da força de trabalho, direcionadas ao cuidado familiar em contexto indígena (Brasil, 20I I).

Um dos conceitos norteadores da chave temática vigilância alimentar e nutricional é o de alimentação saudável. Para fins do processo formador, adotou-se a concepção advinda da Pnan 201 I, que caracteriza como a alimentação adequada a cada fase da vida aquela capaz de atender às necessidades biológicas e socioculturais das famílias e aos princípios do uso sustentável dos recursos ambientais para provisão dos alimentos (Brasil, 20l I). Considerando-se a realidade alimentar rio-negrina, entendeu-se que a alimentação tradicional indígena ali consumida obedecia aos requisitos necessários a uma alimentação saudável, razão pela qual se acordou a equivalência entre dieta tradicional e dieta saudável nas atividades formativas.

\section{Ações formativas adotadas para o campo da vigilância alimentar e nutricional}

Para além da seleção de conteúdos, as estratégias pedagógicas priorizadas nessa fase do processo formador buscaram a recuperação e integração de temas desenvolvidos em fases formativas anteriores no curso, bem como o enriquecimento das discussões sobre vigilância alimentar e nutricional. Tais estratégias foram divididas em dois grupos, conforme a seguir:

Grupo A - Estratécias pedagóGicas adotadas para elaboraçÃo do diaGnÓstico da situaçÃo ALIMENTAR NAS ALDEIAS

- Recuperação de mapas temáticos evidenciando a distribuição de recursos naturais que garantem a reprodução da vida familiar no território: na Etapa Formativa I, 
os estudantes tinham produzido diversos mapas artesanais, dispondo neles informações, como a distribuição de fontes alimentares (mananciais de pesca, locais propícios à caça e à coleta de frutos selvagens, e terras para plantio de roças) usadas pelas famílias indígenas. Naquela etapa, a produção de tais mapas atendeu ao objetivo pedagógico de descrever e compreender o território indígena e seus variados espaços. Na Etapa Formativa II, os mapas visavam demonstrar a distribuição, abundância ou escassez de alimentos tradicionais e os conhecimentos indígenas que garantem a (re)produção dessas práticas. Também foram utilizados como suporte para discutir a história social das etnias de origem dos estudantes e as mudanças geradas pelo contato interétnico que vêm alterando o perfil alimentar indígena.

- Levantamento de práticas alimentares tradicionais, mitos e ritos associados à pesca, caça e cultivo, preparo da comida e restrições alimentares nas diversas fases da vida: sobre algumas etnias rio-negrinas já havia informações disponíveis, as quais foram recuperadas e discutidas com os estudantes. Os alunos também desenvolveram atividades de ensino por meio da pesquisa, coletando informações desse teor entre os conhecedores da tradição em suas próprias famílias e aldeias. O curso contou com a presença de conhecedores nativos da tradição, que atuaram também nas salas de aula abordando, em seu próprio idioma, temas mítico-rituais relacionados à alimentação. Além de valorizar o conhecimento indígena sobre alimentação, tais atividades visavam pôr em evidência os valores culturais, afetivos e de autonomia correlatos às práticas alimentares nativas. Também buscavam estimular a preservação e/ou retomada de alimentos tradicionais cujo uso pudesse estar em declínio devido à concorrência com os produtos industrializados e suprir os estudantes com materiais e recursos pedagógicos para abordar a temática nas aldeias em que atuavam.

- Política dos grupos de parentesco (sibs e fratrias): a influência desses elementos da estrutura social nas etnias rio-negrinas é crucial na gestão dos mananciais de pesca que, no Alto Rio Negro, representam importante fonte de alimentos de origem animal. O acesso a esses mananciais é desigual, já que em grande parte depende do prestígio dos grupos de parentes que ancestralmente controlam os melhores locais de pesca, instituindo-se um delicado processo de gestão das fontes alimentares que pode resultar em conflitos intercomunitários. A discussão sobre a política do parentesco também tinha sido trabalhada no início da Etapa Formativa I e foi retomada para analisar variáveis políticas que intermedeiam o acesso às terras férteis para o plantio e aos lagos particularmente piscosos. A literatura etnológica 
rio-negrina identifica uma clara conexão entre o prestígio (maior ou menor) de sibs e fratrias e o acesso (maior ou menor) às fontes de alimento nos territórios indígenas, demonstrando que as relações de prestígio e de poder entre grupos de parentes influenciam decisivamente os níveis nutricionais a serem monitorados pelos AIS. Tais temas foram objeto prioritário de discussão nessa etapa.

- Classificação dos alimentos e análise crítica do teor nutricional dos alimentos processados e ultraprocessados consumidos nas aldeias: a circulação de alimentos processados e ultraprocessados entre as famílias é ampla e generalizada, coexistindo com o consumo de alimentos tradicionais indígenas. Tal como ocorre nas cidades, os alimentos baratos o suficiente para serem adquiridos por famílias de baixa renda - como é o caso da maioria das famílias indígenas no Alto Rio Negro - são aqueles com pior teor nutricional, ou seja, com elevados níveis de sal, gordura, açúcares e conservantes. Em razão desse cenário, uma das estratégias pedagógicas utilizadas no curso tratou de capacitar os estudantes para: analisar as informações nutricionais descritas nas embalagens; compreender e calcular as necessidades diárias de sal, gordura e açúcares; e analisar cardápios rotineiros das famílias mediante observação direta do consumo, estimando valores aproximados do consumo diário de sal, açúcar e gorduras por pessoa. Mais do que obter um cálculo preciso, o exercício visava analisar globalmente a qualidade da dieta nas famílias; promover a comparação entre os cardápios baseados em alimentos tradicionais e processados; e chamar atenção para os altos teores de consumo de sal, açúcar e gordura nas dietas com maior proporção de alimentos introduzidos no contato interétnico. O levantamento de cardápios, construídos com base na observação de campo feita pelos estudantes, também propiciou a elaboração de um perfil de consumo alimentar pelas famílias indígenas observadas pelos estudantes, o qual foi devidamente analisado e problematizado no processo formador, bem como a noção de transição alimentar e sua expressão concreta no cotidiano das aldeias.

- Discussão sobre a Pnan: os documentos oficiais relativos ao tema foram apresentados e analisados, problematizando-se seus avanços, teor etnocêntrico e dificuldades de operacionalização de suas premissas, objetivos e estratégias de implementação nas terras indígenas. Nesse núcleo temático também se apresentou e se discutiu a situação nutricional dos povos indígenas no Brasil e, no caso rio-negrino, se analisaram as informações já disponíveis para algumas etnias, sobre níveis nutricionais de mulheres e crianças indígenas, que se mostram bastante comprometidos em algumas microrregiões. 
Grupo B - EstratécIas pARA O deSENVOLVIMENTO dE AÇÕES DE VIGILÂNCIA ALIMENTAR E NUTRICIONAL

- Avaliação e monitoramento nutricional de crianças menores de 5 anos e gestantes: os estudantes foram capacitados a desenvolver vigilância alimentar e nutricional, mediante realização de antropometria, avaliação e classificação da situação nutricional, compreensão da lógica e modos de operar do Sisvan e preenchimento de seus formulários. Também aprenderam a revisar o cartão da criança compreendendo e analisando os campos relativos ao monitoramento nutricional. Aprenderam também a construir a curva de crescimento no cartão e avaliar a situação nutricional da criança. Procedimento similar foi desenvolvido para a vigilância nutricional da gestante. Para efetivar o manejo das técnicas de antropometria, os estudantes receberam balanças de precisão, fitas métricas e aprenderam a fabricar seus próprios antropômetros para tomada de medidas em crianças pequenas. Igualmente foram fornecidos os impressos que deveriam manejar, associados a um amplo conjunto de exercícios com situações simuladas que favorecessem o correto registro de informações requeridas pelo Sisvan e cartão da criança, potencializando o aprendizado das ações de vigilância alimentar e nutricional.

- Reconhecimento da ocorrência de problemas de saúde com repercussões negativas nos níveis nutricionais, tais como diarreia, desidratação e anemia. Além do reconhecimento clínico da desnutrição, a formação profissional capacitou os AIS a ofertar os primeiros cuidados aos acometidos, promovendo o controle dos casos e encaminhando-os para outros membros da equipe, quando necessário. A maioria dos AIS presentes no curso já detinha informações prévias sobre tais temas, pois todos já tinham sido ministrados em treinamentos anteriores. Desse modo, as estratégias pedagógicas valorizaram a recuperação dos saberes prévios dos estudantes, auxiliando-os a compreender as correlações existentes entre esses problemas de saúde e a situação nutricional das crianças sob seus cuidados na comunidade.

- Educação e comunicação em saúde: tomando o conjunto de informações trabaIhadas no curso, os estudantes foram orientados a elaborar materiais educativos que propiciassem a abordagem dos temas de alimentação nas aldeias, versando sobre os principais tópicos trabalhados no curso para esse conjunto de conteúdos. Para ações educativas a serem desenvolvidas em espaços coletivos comunitários, valorizou-se a produção de materiais educativos nas línguas nativas dos estudantes, abordando a alimentação tradicional e incentivo ao aleitamento materno. Os estudantes também foram orientados a desenvolver atividades educativas sobre 
os riscos gerados pelos alimentos processados e a prevenção do seu consumo. A orientação relativa aos perfis nutricionais (adequados ou inadequados) das crianças monitoradas foi canalizada para o espaço doméstico, a ser desenvolvida na visita domiciliar, visando evitar potenciais constrangimentos para as famílias com crianças de baixo e muito baixo peso.

- Visita domiciliar: um conjunto de técnicas ativas, coletivas e participativas de ensino-aprendizagem foi utilizado para elaborar um roteiro de visita domiciliar capaz de apoiar as ações de monitoramento da situação nutricional. O roteiro visava auxiliar o AIS a traçar um plano definido de ação a ser seguido durante a realização das visitas domiciliares, abrangendo todos os passos necessários para efetuar a vigilância nutricional.

O curso adotou uma oferta equilibrada de atividades teóricas e práticas, em sala de aula e na comunidade, bem como de conhecimentos científicos e da tradição indígena para efetivar o processo de ensino-aprendizagem, buscando estimular o protagonismo dos estudantes e o ensino por meio da pesquisa desenvolvida junto com os conhecedores da tradição indígena dos grupos de parentesco dos agentes de saúde.

Esse conjunto de estratégias pedagógicas propiciou o reconhecimento do espaço social-territorial onde se produzem os perfis nutricionais a serem monitorados pelos agentes de saúde. Trata-se de um diagnóstico situacional que permite contextualizar os problemas de saúde no tempo, espaço e no cotidiano da aldeia, favorecendo o diálogo com as famílias, a valorização das culturas ancestrais que produziram saberes sobre o ambiente e suas fontes alimentares e a discussão, em comunidade, sobre as melhores estratégias de superação dos problemas identificados pela equipe de saúde.

\section{Atribuições dos AIS em vigilância alimentar e nutricional}

O processo formador gerou um conjunto de atribuições a serem desenvolvidas pelos AIS no âmbito da vigilância alimentar e nutricional, descritas a seguir:

I. Reconhecer os alimentos tradicionais consumidos no território, incentivar a produção de alimentos na própria comunidade e a valorização dos conhecimentos tradicionais a eles associados.

2. Identificar, com os(as) conhecedores(as) da tradição, os cuidados associados à amamentação e alimentação das crianças e mulheres indígenas, estimulando a preservação de práticas alimentares e cuidados tradicionais que visem à manutenção da saúde por meio da alimentação saborosa e saudável. 
3. Desenvolver ações de educação em saúde mediante a discussão de temas como transição alimentar e segurança alimentar no território indígena, apontando vantagens e desvantagens da introdução de novos alimentos e problematizando a mudança atualmente em curso na dieta indígena.

4. Realizar levantamento dos alimentos processados e ultraprocessados consumidos na aldeia e discutir os riscos associados ao seu uso.

5. Promover a (re)valorização da alimentação tradicional, com o objetivo de reduzir o consumo de alimentos enlatados, empacotados e com teor excessivo de açúcar, sal e gorduras.

6. Pactuar com a comunidade a realização de ações de monitoramento nutricional, situando os problemas nutricionais atualmente enfrentados pelas comunidades indígenas e a necessidade de avaliação antropométrica periódica da população infantil e de mulheres grávidas.

7. Realizar o acompanhamento nutricional das crianças de 0 a 5 anos e mulheres grávidas, por meio de técnicas antropométricas (pesagem, medidas e classificação nutricional), seguindo os procedimentos adotados pelo Sisvan. Recomenda-se a realização quinzenal da antropometria para crianças identificadas como de baixo peso para a idade e semanal para crianças com muito baixo peso para a idade, propiciando acompanhamento regular do progresso da situação nutricional. Para as gestantes, recomenda-se o monitoramento mensal.

8. Conhecer o Sisvan e realizar o preenchimento correto das informações requeridas nos mapas de registro desse sistema.

9. Conhecer a caderneta da criança e efetuar o registro de dados que permitam monitorar a curva de crescimento, identificando situações de risco nutricional.

10. Realizar visitas domiciliares para o monitoramento alimentar e nutricional das crianças e gestantes, com ênfase naquelas classificadas com baixo e muito baixo peso e/ou baixa estatura para a idade e baixo IMC. As visitas domiciliares devem ser entendidas como o momento e o espaço ideais para discutir, em privado, o diagnóstico nutricional dos membros da família e pactuar as condutas necessárias para reversão de quadros desfavoráveis identificados pelo AIS.

I I. Monitorar com regularidade a situação nutricional de crianças e gestantes na comunidade, com o intuito de subsidiar a atuação de outros membros da equipe nessa temática. 
12. Identificar quadros de risco nutricional, ofertar cuidados aos acometidos, em seu nível de competência, e encaminhar para avaliação por outros membros da equipe os problemas nutricionais e agravos associados, como baixo e muito baixo peso, desnutrição, diarreia, desidratação e anemia.

13. Participar de discussões comunitárias e iniciativas para estimular a produção e consumo dos alimentos tradicionais e iniciativas familiares que visem à melhoria da nutrição e alimentação de crianças e gestantes e a redução da dependência de alimentos introduzidos no contato interétnico.

14. Participar das iniciativas de manejo ambiental, desenvolvidas por organizações indígenas e entidades não indígenas, visando ampliar a disponibilidade de alimentos no território.

Conteúdo programático desenvolvido na temática vigilância alimentar e nutricional: alguns exemplos

UNIDADE I - DIAGNÓSTICO DA STTUAÇÃO ALIMENTAR NO TERRTIÓRIO INDÍGENA

I.I. Levantamento das origens mitológicas dos alimentos na cultura indígena.

1.2. Levantamento das concepções e práticas rituais sobre alimentação tradicional indígena.

1.3. Levantamento dos modos alimentares e restrições dietéticas segundo as fases da vida na cultura indígena.

1.4. Mapeamento e gestão etnopolítica dos recursos e fontes alimentares no território (terra indígena).

1.5. Classificação dos alimentos e pirâmide alimentar segundo o conhecimento do mundo do branco.

1.6. Segurança e soberania alimentar: discussão sobre o significado desses conceitos.

1.7. Noções básicas sobre transição alimentar e nutricional.

1.8. O contato interétnico e a introdução de alimentos processados e ultraprocessados na dieta indígena.

1.9. Sustentabilidade alimentar e manejo ambiental no território indígena. 
UNIDADE 2 - VIGILÂNCIA NUTRICIONAL NO SISTEMA DE SAÚDE

2.I. Pnan: aspectos gerais e apreciação crítica de seu uso em culturas indígenas.

2.2. Situação nutricional dos povos indígenas no Brasil e na etnia dos estudantes.

2.3. Monitoramento nutricional de crianças e gestantes através do Sisvan.

2.3.I. Antropometria e classificação nutricional de crianças e gestantes.

2.3.2. Monitoramento e informação nutricional de crianças e gestantes segundo os formulários do Sisvan.

2.4. Cartão/caderneta da criança: revisão de seus campos e registro de dados para monitoramento da curva de crescimento da criança.

2.5. Aleitamento materno: conceito, características no mundo indígena e importância para nutrição infantil.

2.6. Reconhecimento e condutas, no nível de competência de técnico de nível médio, de problemas nutricionais e agravos associados: parasitoses intestinais, diarreia, desidratação, desnutrição e anemia.

2.7. Encaminhamento de problemas nutricionais e agravos associados a outros membros da equipe de saúde indígena para tratamento, quando necessário.

UNIDADE 3 - VIGILÂNCIA ALIMENTAR EM ALDEIAS INDÍGENAS

3.I. Levantamento de cardápios diários, rotinas alimentares, alimentos disponíveis nas casas, visando à elaboração de orientações alimentares para famílias indígenas acompanhadas pelos agentes de saúde.

3.2. Reconhecimento de necessidades diárias de ingestão açúcar, sal e gorduras e comparação com as informações nutricionais contidas em embalagens dos alimentos processados e ultraprocessados.

3.3. Estimativas simplificadas de ingestão diária de açúcar, sal e gorduras contidas em alimentos processados e ultraprocessados utilizados cotidianamente pelas famílias nas aldeias.

3.4. Caracterização da qualidade da dieta das famílias e dos riscos associados ao abuso do consumo de sal, açúcar, gorduras e conservantes. 
3.5. Visita domiciliar do AIS para realização de vigilância nutricional e orientação alimentar às famílias acompanhadas, visando à correção de déficit alimentar, quando encontrado.

3.6. Educação em saúde: ensino e aprendizado de técnicas educativo-comunicativas de elaboração e uso de materiais educativos (em língua indígena e em português) versando sobre alimentação e nutrição, a serem apresentados coletivamente e discutidas com a comunidade.

3.7. Atividades comunitárias para valorização da tradição alimentar do grupo e revitalização de alimentos e cardápios tradicionais.

\section{Algumas considerações sobre o processo, os resultados e as dificuldades no desenvolvimento das ações formativas em vigilância alimentar e nutricional}

O tema da alimentação mostra-se particularmente desafiador, dado seu caráter intrinsecamente interdisciplinar, exigindo abordagens complexas que recusam as concepções meramente biológicas que, geralmente, orientam as ações das equipes e serviços de saúde.

A organização curricular das etapas formativas conjugou a temática da transição alimentar - em curso também entre os indígenas - com a dos saberes e práticas tradicionais que propiciam acesso aos recursos alimentares disponíveis na natureza. A rapidez das mudanças e o desconhecimento de suas consequências negativas na vida e na saúde das pessoas foi objeto de grande atenção no curso, que buscou munir os estudantes de informações que os estimulassem a desenvolver seus próprios juízos críticos sobre a temática e a partilhá-los com seus parentes e corresidentes.

O desenvolvimento das atividades se mostrou satisfatório, tendo-se observado uma produtiva reflexão crítica sobre a transição alimentar, um adequado domínio das técnicas de monitoramento nutricional e uma disposição para dialogar com as comunidades e outros membros da equipe multidisciplinar de saúde indígena na busca de aprimorar a oferta de cuidados aos portadores de problemas nutricionais identificados entre crianças e mulheres grávidas. 
Entretanto, a questão alimentar e seus respectivos transtornos é - por sua própria natureza multifacetada - matéria cujo manejo efetivo e resolutividade estão fora da governabilidade de AIS. A capacidade de produzir a comida nos próprios territórios e de garantir o acesso a um perfil alimentar adequado está fora do alcance de muitos povos indígenas, seja por estarem presos à engrenagem da economia de mercado, por enfrentarem ameaças às suas terras, seja por terem terra legalmente demarcadas reduzidas ou esgotadas e incapazes de garantir a autonomia alimentar.

Mesmo no caso do Alto Rio Negro, onde os indígenas dispõem de grandes extensões de terras demarcadas e não enfrentam devastação ambiental expressiva em seu território, a mudança nos processos de ocupação do espaço e a penetração das instituições não indígenas vêm potencializando a sedentarização das famílias. Dentre diversas consequências, a nova condição acarreta o esgotamento das terras e de outras fontes alimentares diretamente puncionadas no entorno imediato das aldeias. No entanto, não se pode desprezar a produção do gosto e das preferências alimentares das gerações mais jovens pelos alimentos processados e ultraprocessados - um fenômeno mundial -, que aliadas às crescentes dificuldades em preservar os saberes tradicionais sobre o ambiente e as técnicas de produção e extração de alimentos na natureza, ameaçam seriamente a autonomia alimentar das etnias que ali vivem.

No que diz respeito ao plano de aplicação de seus conteúdos na organização do cuidado, o curso enfrentou problemas de diversas ordens. O principal deles foi que o modelo formativo adotado para os AIS se pautou pelas premissas da vigilância e promoção da saúde, ao passo que o modelo assistencial adotado no DSEI não logrou sucesso em associar ações assistenciais às atividades preventivas e de promoção da nutrição e alimentação saudável. Nesse âmbito, a atuação das equipes continuou refém das situações de emergência, em que a instalação de transtornos agudos - como a diarreia e as infecções respiratórias - em crianças previamente desnutridas passam a ameaçar a vida. Tais eventos monopolizam o esforço das equipes dificultando, ou mesmo impedindo, o investimento em ações capazes de corrigir o perfil nutricional instalado na raiz dos quadros graves que exigem remoção imediata. Essa contradição dificultou a efetivação dos conteúdos de aprendizado no trabalho cotidiano dos agentes de saúde, já que as ações de vigilância alimentar e nutricional pressupõem uma atuação integrada e articulada de toda a equipe, o que um curso de formação de agentes de saúde não pode garantir isoladamente. 


\section{Reflexões sobre as potencialidades e os desafios encontrados}

O processo pedagógico se comprometeu com o fortalecimento da autonomia indígena nas escolhas alimentares e na condução de estratégias para a produção local de alimentos, pari passu à valorização e revitalização dos sistemas alimentares tradicionais calcados na cosmopráxis indígena.

O caráter interdisciplinar e intersetorial da alimentação foi reconhecido e respeitado mediante a adoção de um conjunto de abordagens diagnósticas e investigativas direcionadas ao reconhecimento dos processos produtivos envolvidos no plantio das roças e na punção de fontes alimentares no espaço natural. Também foram trabalhadas a gestão etnopolítica dos espaços mais propícios à obtenção de alimentos e as práticas alimentares fortemente mediadas pelas relações de hierarquia e reciprocidade instituídas pelo regime rio-negrino de parentesco. O processo formador albergou também as discussões sobre a mudança cultural e a transição alimentar, fortemente induzidas pelo contato interétnico e pela penetração da economia de mercado que potencializa a aquisição de alimentos processados e ultraprocessados nos espaços citadinos mais próximos às terras indígenas.

Esse conjunto de atividades exemplifica o esforço em superar as abordagens meramente biológicas da vigilância alimentar e nutricional, ainda que sem desprezar as contribuições dos indicadores nutricionais para o monitoramento de perfis nutricionais que persistem nos territórios indígenas.

Dentre as dificuldades a serem superadas, apontamos a necessária revisão do modelo assistencial praticado no DSEI e a dificuldade dos AIS em legitimarem suas novas atribuições perante os outros membros da equipe, numa dinâmica que remete à hierarquia das profissões. À medida que o processo formador progredia, os profissionais de outras categorias, já estabelecidas e hegemônicas no DSEl, demonstravam desconfiança no novo perfil de atuação AIS como técnicos de nível médio, ainda que a maioria deles fosse capaz de desenvolver as ações de vigilância alimentar e nutricional com qualidade e efetividade. A novidade da iniciativa e as contradições internas que ela gera na atuação cotidiana das equipes podem estar na raiz do problema e podem ser facilmente superadas no processo de gestão da nova força de trabalho que emergiu do processo formador. 


\section{5}

\section{Cuidado à saúde da criança indígena}

Neste capítulo apresentamos a experiência de implementação curricular do CTACIS no âmbito dos conteúdos e competências relativos ao que denominamos de cuidado à saúde da criança indígena. Pretendemos destacar estratégias didáticas utilizadas, definição de conteúdos e discutir os desafios do trabalho do AIS na atuação no cuidado à criança indígena.

O grupo populacional denominado criança não é uma categoria biológica natural nem consensual nos diversos contextos socioculturais e institucionais. O Fundo das Nações Unidas para a Infância (Unicef) o define como toda pessoa menor de 18 anos de idade; o Estatuto da Criança e Adolescente (ECA) limita-o à idade de 12 anos incompletos; já o MS considera como público-alvo das políticas de saúde da criança aquelas com até 10 anos de idade. No âmbito dos povos indígenas, o entendimento do que seja infância, ou categoria social similar, demanda a construção de um olhar específico e diferenciado. Na implementação de ações de saúde pelas equipes multidisciplinares de saúde indígena, optamos por tentar conciliar as diretrizes gerais e nacionais com as concepções e práticas locais voltadas para esse público.

Segundo o Censo 2010, na estrutura por idade da população indígena, o grupo etário de crianças e adolescente (entendido por esse órgão como as pessoas menores de 14 anos) representa 36,2\% do total. O maior peso relativo desse grupo etário se aprofunda na população indígena residente em área rural, passando a corresponder a $45 \%$ da população (IBGE, 20 I0). Se analisarmos as pirâmides populacionais produzidas pelo Instituto Brasileiro de Geografia e Estatística (IBGE), percebe-se que esse é um perfil típico da região Norte, onde se localiza o Alto Rio Negro. Naquela região observa-se que, para a população masculina, a faixa etária de 0 a 4 anos corresponde a 16,1\%, e a feminina a 16,6\%; na faixa etária de 5 a 9 anos, homens e mulheres correspondem a 14 , $7 \%$ e 15\%, respectivamente. Na faixa etária de 10 a 14 anos essa proporção é de 13\% 
para homens e 13,1\% para as mulheres indígenas (Disponível em:<http://indigenas. ibge.gov.br/piramide-etaria-2.html>).

Embora relevantes, tais informações são incapazes de subsidiar o trabalho do agente de saúde nas aldeias. Em razão disso, o exercício de construção da pirâmide populacional da aldeia de cada estudante também foi desenvolvido no CTACIS. Dentre os resultados da iniciativa, identificou-se, de modo congruente com os achados do IBCE, que nas comunidades indígenas do Alto Rio Negro predominava o segmento menor que 15 anos, conforme a Figura 13.

Figura 13 - Pirâmide populacional de comunidade

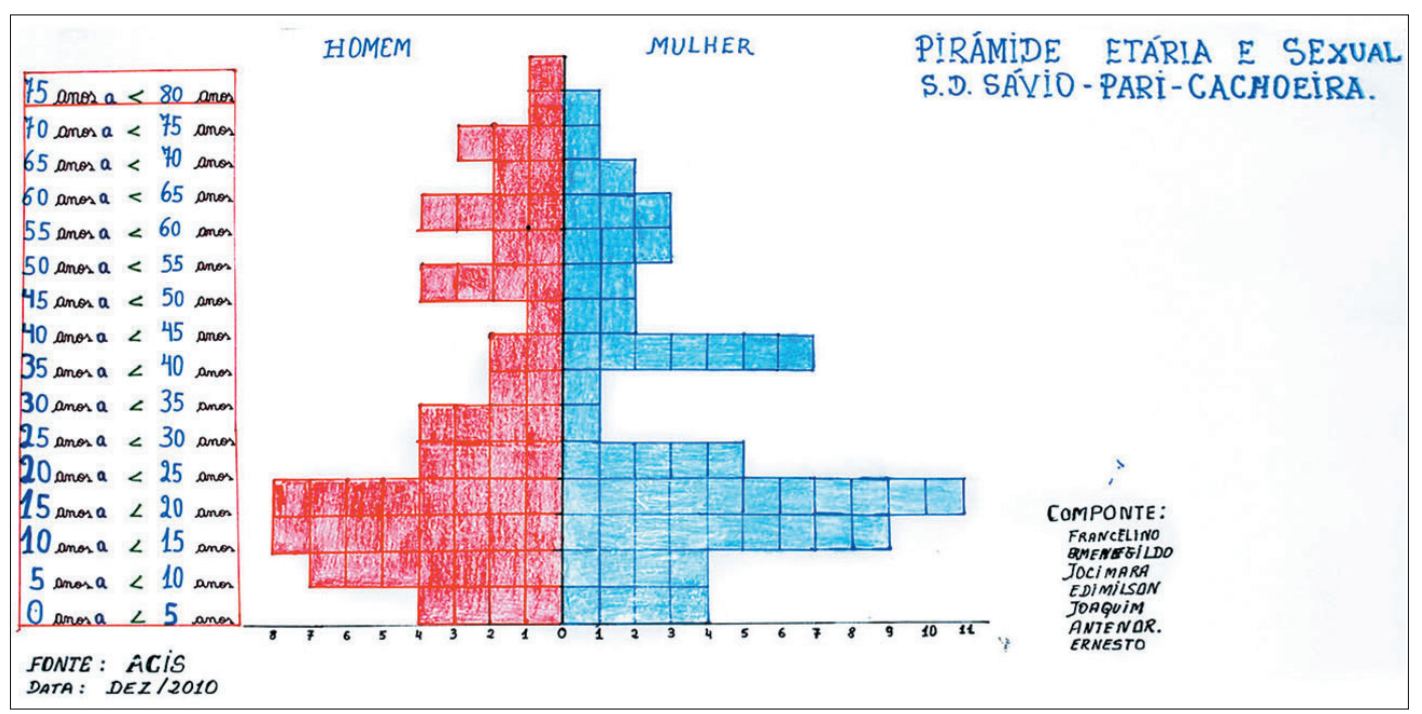

Acervo CTACIS (2009-2015).

Os dados epidemiológicos dessa população são escassos em virtude do fato que o Sistema de Informações da Atenção à Saúde Indígena (Siasi) ainda não foi plenamente implementado, e seus dados não são disponibilizados para consulta. Assim, para analisarmos a situação de saúde da população indígena infantil, somente pudemos contar com estudos dispersos realizados em alguns grupos étnicos e, destacadamente, o I Inquérito Nacional de Saúde e Nutrição dos Povos Indígenas, finalizado em 2009.

Basta, Orellana e Arantes (2012) apontam altos coeficientes de mortalidade infantil (CMI) que, apesar de uma redução nos últimos anos, ainda apresentavam média de 4I,9 por cem mil nascidos vivos e ultrapassavam cem por mil nascidos vivos em alguns grupos étnicos. Esse quadro revela a heterogeneidade e gravidade da situação de saúde das populações indígenas, pois a média nacional em 2006 era 25, I por mil nascidos vivos (Basta, Orellana $\&$ Arantes, 20I2). Os autores também destacam que no período entre 2003 e 2006 as principais causas de mortalidade infantil entre crianças indígenas foram 
as doenças do aparelho respiratório, as causas mal definidas, as doenças infecciosas e parasitárias e as afecções originadas no período perinatal. Vale destacar que as pneumonias são mencionadas como principal causa de consultas, internações e óbitos de crianças menores de 5 anos. Ademais, agravando a situação de vulnerabilidade das crianças, existe uma alta prevalência de desnutrição crônica, superior à das crianças não indígenas.

Observa-se também que $70 \%$ das causas de mortalidade infantil ocorreram no período pós-neonatal (entre 28 e 364 dias após o nascimento), o que indica problemas associados às más condições de vida, às mortes por causas evitáveis e às falhas no acesso e resolutividade das ações de APS (Basta, Orellana $E$ Arantes, 20I2). São conclusões condizentes com a carência de sistemas de saneamento e de fornecimento adequado de água potável nas comunidades indígenas.

O I Inquérito Nacional de Saúde e Nutrição dos Povos Indígenas teve como um dos objetivos descrever a situação nutricional e alimentar e outros fatores determinantes da saúde das crianças indígenas menores de 5 anos nas quatro macrorregiões do país. Com relação à situação nutricional, identificaram uma prevalência de 5,9\% de peso baixo para idade, $25,7 \%$ de estatura baixa para a idade e 1,3\% de peso baixo para a estatura (Horta et al., 2013). O primeiro indicador nos apresenta um panorama da desnutrição aguda, o segundo da desnutrição crônica e o terceiro o efeito das perdas de peso no crescimento das crianças. Os dois primeiros indicadores foram maiores entre as crianças indígenas da região Norte, com I I,4\% e 40, 8 \% das crianças com baixo peso para idade e baixa estatura para idade (Horta et al., 2013).

Das crianças entrevistadas no I Inquérito, 23,5\% haviam tido sintomas de diarreia na última semana, percentual maior na região Norte, com frequência de 38, 1 \% (Escobar et al., 2015). A maior frequência de diarreia foi encontrada na faixa etária entre 6 e 23 meses, com 35,9\% dos casos (Escobar et al., 2015). Das crianças com episódios de diarreia, a pesquisa identificou que somente $55,9 \%$ receberam soro de reidratação oral. Com relação às infecções respiratórias agudas (IRA), a prevalência de tosse, congestão nasal, pneumonia e pneumonia com febre foi de 44,4\%, 31\%, 2,63\% e I,28\% (Cardoso et al., 20 I5), sendo mais frequente nas crianças vivendo nas regiões Sul, Sudeste e Norte. Observou-se também que 19\% das crianças haviam sido hospitalizadas no último ano, sendo as principais causas a diarreia e as IRA. Esses dados apontam para a necessidade de fortalecimento das ações de saúde no âmbito da APS, e principalmente dos fatores que influenciam o estado nutricional e alimentar dessas crianças, e das estratégias de atendimento das crianças com queixas de IRA e diarreia.

Entretanto, se poucos dados são disponíveis sobre a situação de saúde das crianças indígenas, existe ainda menos conhecimento sobre o contexto da infância indíge- 
na. Temos poucas pesquisas antropológicas sobre o tema e um número ainda menor de trabalhos que abordem as especificidades dos cuidados à saúde na infância dos povos indígenas.

Na tentativa de dimensionar, minimamente, o significado dessas informações, retomaremos algumas contribuições de Clarice Cohn no seu estudo sobre as crianças xikrin (Cohn, 2000). Primeiramente, a autora enfatiza que as crianças devem ser entendidas em suas especificidades e não como "adultos em miniatura”, isso significa entender a participação ativa das crianças na vida social. Essa perspectiva visa superar a ideia da criança como um receptáculo de valores, comportamentos e conhecimentos, para entendê-las como pessoas plenas (Cohn, 2000).

Essa dimensão da construção da pessoa, ou dos atributos de ser humano, deve ser analisada no interior de cada grupo social, não sendo possível fazer uma generalização entre os grupos indígenas. A construção social de pessoa se difere da concepção ocidental de indivíduo, pois não é um dado a priori, mas um constructo social contínuo (Cohn, 2000). A infância nos grupos indígenas pode representar estágios, ou parte desse processo que conforma a constituição da pessoa humana em dado grupo étnico, nos quais entram dimensões relacionadas à formação dos corpos, aos cuidados, à alimentação e à construção do parentesco.

No caso das crianças xikrin, Cohn (2000) identificou que para esse grupo étnico, as crianças nascem compostas por corpo (in) e alma (karon). Ponto de vista, por exemplo, distinto entre os guarani mbya, que, segundo Ferreira (20l3), entendem que o recémnascido não possui ainda o "espírito" assentado plenamente em seu corpo, e, portanto, o pai deve confeccionar brinquedos para auxiliar nesse processo. Para os xikrin (Cohn, 2000), deve-se tomar muito cuidado com a pele do recém-nascido que, sendo "mole", não favorece a integração no corpo (in) da alma (karon).

Outra preocupação para evitar a perda do karon é que as crianças não chorem muito. Como dimensão mais característica da infância xikrin, Cohn (2000) destaca a preocupação com o desenvolvimento da faculdade de compreensão, que está associada a uma dimensão sensorial, pois "saber, conhecer, aprender, entender e compreender estão todos inseridos em suas capacidades, a de ver e ouvir" (Cohn, 2000: 200). Essa dimensão envolve orientações alimentares, uso de remédios tradicionais, entre outras práticas, por outro lado, se espera uma participação ativa da criança, demonstrando curiosidade e iniciativa.

Consideramos fundamental essa profundidade de conhecimentos sobre a perspectiva indígena de infância, pois entendemos que a atenção diferenciada no subsistema de saúde indígena se refere "não à incorporação de práticas tradicionais aos serviços 
de saúde primária, e sim como articulação entre esses e as práticas de autoatenção existentes na comunidade em particular" (Langdon, 2004: 42). Não pretendemos que os profissionais da saúde e o AIS sejam responsáveis pela implementação de cuidados tradicionais, mas indicamos que precisam ativamente se interessar, conhecer e respeitar o uso dos saberes e práticas locais.

Quando falamos em práticas de autoatenção, nos referimos a duas dimensões desse conceito proposto por Menéndez (2003), a primeira se refere aos "processos de reprodução biossocial", que envolvem os usos e cuidados corporais, as recomendações e restrições alimentares, as normas de higiene pessoal e coletiva, as regras sociais, entre outros. O segundo nível da autoatenção se refere diretamente às representações e práticas relacionadas com problemas de saúde, em sua prevenção ou cura.

$\mathrm{Na}$ abordagem curricular da saúde da criança, pretendíamos construir essa relação entre autoatenção e práticas de APS, dessa forma, no processo de desenvolvimento curricular, nos debruçamos sobre dois desafios. O primeiro se refere à abordagem sociocultural específica da infância e do cuidado à criança nas comunidades indígenas e, o segundo, à discussão e à definição dos conteúdos relativos às atribuições a serem desenvolvidas pelos AIS nas equipes.

Para definição dessas novas atribuições dos AIS, solicitou-se aos gestores e coordenações técnicas da área de saúde da criança do DSEI Alto Rio Negro os principais documentos orientadores da organização da atenção à saúde da criança. Com base nesses documentos, a coordenação do curso discutiu uma proposta curricular para o desenvolvimento do tema, tratando do seu conteúdo com profissionais e gestores locais antes da realização do curso. Dessa triagem prévia foram selecionados alguns documentos técnicos do MS e da Sesai para utilização no curso: diretrizes da Política Nacional de Atenção Integral à Saúde da Criança (Pnaisc); Cadernos de Atenção Básica, n. 33, "Acompanhamento do crescimento e desenvolvimento infantil"; documentos do Programa Nacional de Imunização; diretrizes do Atendimento Integral às Doenças Prevalentes da Infância; e documentos do Sistema de Vigilância Alimentar e Nutricional (Sisvan) e Sisvan indígena. Também foi fundamental nesse momento o envolvimento maior dos profissionais da saúde do DSEIRN na docência. Assim, médicos, odontólogos e enfermeiros do DSEl atuaram ativamente na elaboração dos planos de aula, produção de materiais didáticos e condução das atividades didáticas.

Para darmos conta das dimensões socioculturais da infância e aspectos relativos à autoatenção foi essencial termos antropólogos na equipe de coordenação do curso e no corpo docente acompanhando a construção e implementação do plano de aulas. 
Considerando que a maior parte do corpo docente nesse momento era formada por profissionais da saúde, a atuação desses antropólogos era fundamental para provocar reflexões e intervenções nas atividades didáticas sobre a problemática da implementação da atenção diferenciada.

\section{Implementação curricular dos componentes relativos à saúde da criança indígena no CTACIS}

Apresentamos a abordagem curricular do cuidado à criança indígena no CTACIS com base na escolha de momentos privilegiados dos cinco diferentes polos formativos, num ordenamento seguido nas aulas. Em termos de caracterização geral, o componente relativo à saúde da criança indígena ocupou o correspondente a cerca de 120 horas de atividades presenciais, abordando as seguintes temáticas:

- Fases da vida e cuidados na perspectiva indígena.

- Caracterização e diagnóstico da infância no território indígena.

- Priorização dos problemas na saúde da criança: comunidade, AIS e política nacional de saúde.

- Determinantes e condicionantes do crescimento e desenvolvimento saudável.

- Puericultura e cartão da criança.

- Antropometria e Sisvan: técnicas e formulários.

- Vigilância alimentar e nutricional: rotina alimentar, alimentos disponíveis e construção de orientações.

- Aleitamento materno.

- Bolsa Família.

- Imunização e PNI (Programa Nacional de Imunização): histórico, conceitos, doenças imunopreveníveis, vacinas, calendário vacinal, trabalho da equipe e do AIS.

- Adoecimento infantil: situação no ARN, doenças prevalentes, condicionantes e determinantes do adoecimento, Atenção Integrada às Doenças Prevalentes na Infância (AIDPI) (sinais de perigo, tosse, febre, diarreia, dor de ouvido)

- Organização das rotinas e das visitas domiciliares do AIS no âmbito da saúde da criança. 
Selecionamos para este capítulo alguns conteúdos e estratégias metodológicas que permitem ilustrar como abordamos as dimensões socioculturais da infância e das práticas de autoatenção no cuidado das crianças nas comunidades indígenas e a construção das atribuições profissionais em saúde para os AIS na sua atuação como membros da equipe multidisciplinar em saúde.

Conforme apontamos anteriormente, as fases da vida são construções socioculturais, de modo que o primeiro desafio para abordagem da saúde da criança foi a identificação e caracterização dessa fase. Esse trabalho de mapeamento das fases da vida foi subdividido em cada polo formativo de acordo com a diversidade étnico-linguística dos alunos. De maneira geral, realizamos uma pesquisa local que envolveu coleta e sistematização de informações acerca das características de cada fase da vida, os nomes em língua indígena e os cuidados requeridos nesses momentos da vida.

As fontes utilizadas para captar essas informações eram os próprios alunos, entrevistas com moradores das comunidades indígenas onde o curso era realizado e conversas coletivas com velhos conhecedores das tradições que eram convidados para as aulas. Os alunos inicialmente preparavam uma sistematização inicial em grupos, segundo pertencimento étnico-linguístico. Em seguida realizavam entrevistas, para as quais havia um roteiro elaborado em conjunto com os alunos e eram aplicadas na comunidade, individualmente ou em grupo. As entrevistas eram realizadas em língua indígena e depois traduzidas para os professores e colegas. Por fim, os velhos conhecedores faziam suas narrativas sobre o tema, em língua indígena, com base em demandas geradas pelos professores, e suas falas eram traduzidas e registradas pelos alunos.

Assim, as informações eram coletadas e discutidas de forma a identificarmos as diferenças entre os grupos étnicos, comentadas pelos velhos conhecedores. Podemos dizer que, ao fim desse processo, coletávamos informações profundas e específicas para cada grupo étnico sobre a fase denominada de infância. Encontramos diversas especificidades que precisam ser consideradas na organização do trabalho da equipe multiprofissional em saúde indígena.

Em termos de resultados gerais, levantaram-se práticas preventivas e curativas tradicionais, benzimentos, orientações dietéticas, resguardos, práticas de higiene, entre outros. Também identificamos os riscos e doenças às quais as crianças estão mais vulneráveis, e dimensões do cuidado familiar e comunitário com as crianças. A seguir apresentamos algumas sínteses de informações coletadas (Quadros 4 e 5). 
Quadro 4 - Descrição das fases da vida, de acordo com o grupo de AIS, do Polo Alto e Médio Içana e Aiari, subgrupo da etnia baniwa, versão em português

\begin{tabular}{|c|c|c|c|}
\hline \multicolumn{4}{|c|}{ Polo-base Tucumã - Exercícios 5 e 6} \\
\hline Nome da fase & $\begin{array}{l}\text { Características } \\
\text { das pessoas } \\
\text { nesta fase }\end{array}$ & $\begin{array}{l}\text { Faixa } \\
\text { etária }\end{array}$ & Cuidados com a saúde e a alimentação \\
\hline Gravidez/gestante & $\begin{array}{l}\text { Criança na } \\
\text { barriga }\end{array}$ & $\begin{array}{l}\text { Antes } \\
\text { de } \\
\text { nascer }\end{array}$ & $\begin{array}{l}\text { O que a mãe não pode comer durante } \\
\text { a gravidez: acutiuaia, tatu, jabuti, } \\
\text { tamanduazinho e yamaro. (Grifo dos alunos) } \\
\text { O que pode comer: sarapó pintado, pirapucu, } \\
\text { aracu, traíra, calango e remédio kodipere. } \\
\text { (Grifo dos alunos) }\end{array}$ \\
\hline Bebê & $\begin{array}{l}\text { O que mama o } \\
\text { leite da mãe, o } \\
\text { que já se senta, } \\
\text { o que engatinha. }\end{array}$ & $\begin{array}{l}0 \text { a I } \\
\text { ano }\end{array}$ & $\begin{array}{l}\text { Antes de dar a primeira comida é preciso } \\
\text { benzimento. } \\
\text { Depois do benzimento, o bebê pode comer: } \\
\text { mingau de maçoca e piaba. }\end{array}$ \\
\hline Criança & $\begin{array}{l}\text { O que já anda, o } \\
\text { que já brinca, o } \\
\text { que já cuida do } \\
\text { seu irmãozinho. }\end{array}$ & $\begin{array}{l}\text { I a } 5 \\
\text { anos }\end{array}$ & Já come tudo: fruta, peixes e caças \\
\hline Criança crescida & $\begin{array}{l}\text { O que já sabe } \\
\text { pescar, o que } \\
\text { ajuda o pai e a } \\
\text { mãe. }\end{array}$ & $\begin{array}{l}6 \text { a } 12 \\
\text { anos }\end{array}$ & Já come tudo. \\
\hline Rapaz ou moça & $\begin{array}{l}\text { Formação já } \\
\text { completa }\end{array}$ & $\begin{array}{l}12 \text { a } 15 \\
\text { anos }\end{array}$ & $\begin{array}{l}\text { O rapaz come tudo; a moça só come o que é } \\
\text { orientado. }\end{array}$ \\
\hline Adulto & $\begin{array}{l}\text { O que já tem seu } \\
\text { pensamento bom } \\
\text { para criar seus } \\
\text { filhos. }\end{array}$ & $\begin{array}{l}16 \text { a } 45 \\
\text { anos }\end{array}$ & Não tem mais problema de alimentação. \\
\hline Adulto & $\begin{array}{l}\text { O que já tem } \\
\text { genro e neto } \\
\text { e já recebe o } \\
\text { benefício que o } \\
\text { governo oferece. }\end{array}$ & $\begin{array}{l}45 \text { a } 60 \\
\text { anos }\end{array}$ & Não tem mais problema de alimentação. \\
\hline Idoso & $\begin{array}{l}\text { O que já anda } \\
\text { com vara na mão } \\
\text { para se apoiar. }\end{array}$ & $\begin{array}{l}\text { Mais de } \\
60 \text { anos }\end{array}$ & Não tem mais problema de alimentação. \\
\hline
\end{tabular}

Acervo CTACIS (2009-20I5). 
Quadro 5 - Nomes das fases da vida segundo os grupos étnicos do Polo Formativo do Baixo Rio Negro

\begin{tabular}{|c|c|c|c|}
\hline $\begin{array}{l}0 \text { a I ano - criança } \\
\text { pequena } \\
\text { Taina Mirim } \\
\text { (nheengatu) } \\
\text { Imagt } \\
\text { (Tukano) } \\
\text { Dânteé Piís } \\
\text { (dow hupda) } \\
\text { Queramo } \\
\text { (baniwa) }\end{array}$ & $\begin{array}{l}\text { I a } 5 \text { anos - criança } \\
\text { Taina } \\
\text { (nheengatu) } \\
\text { Imagu } \\
\text { (tukano) } \\
\text { Dâw Teé } \\
\text { (dow hupda) } \\
\text { Queramo } \\
\text { (baniwa) }\end{array}$ & $\begin{array}{l}6 \text { a } 12 \text { anos - rapaz } \\
\text { ou moça } \\
\text { Taina, Curumim } \\
\text { ou Cunhatã } \\
\text { (nheengatu) } \\
\text { Dawtee Pêeg } \\
\text { (dow hupda) } \\
\text { Waparo } \\
\text { (baniwa) }\end{array}$ & $\begin{array}{l}\text { I } 2 \text { a I } 5 \text { anos - jovem } \\
\text { ou adolescente } \\
\text { Pisasú kurimiasu, } \\
\text { Pisasú kunhamuku } \\
\text { (nheengatu) } \\
\text { Mamu } \\
\text { (tukano) } \\
\text { Daw Pêeg Scaaw } \\
\text { (dow hupda) } \\
\text { Waliparo } \\
\text { (baniwa) }\end{array}$ \\
\hline $\begin{array}{l}\text { I6 a } 45 \text { anos - adulto } \\
\text { Tuiu } \\
\text { (nheengatu) } \\
\text { Buhkt/ Buhkto } \\
\text { (tukano) } \\
\text { Dâw Kâan } \\
\text { (dow hupda) } \\
\text { Pedalia } \\
\text { (baniwa) }\end{array}$ & $\begin{array}{l}45 \text { anos a } 60 \text { anos - } \\
\text { velho } \\
\text { Tuiu } \\
\text { (nheengatu) } \\
\text { Buhkut Buhkto } \\
\text { (tukano) } \\
\text { Dâw Kâan } \\
\text { (dow hupda) } \\
\text { Pedalia } \\
\text { (baniwa) }\end{array}$ & $\begin{array}{l}\text { Mais de } 60 \text { anos - } \\
\text { velho } \\
\text { Tuiuwé } \\
\text { (nheengatu) } \\
\text { Buhku/ Buhkto } \\
\text { (tukano) } \\
\text { Dâw Kâan } \\
\text { (dow hupda) } \\
\text { Pedalia } \\
\text { (baniwa) }\end{array}$ & \\
\hline
\end{tabular}

Acervo CTACIS (2009-20I5).

Para explicar essas atividades, apresentaram-se as definições e classificações das fases da vida no mundo ocidental, portanto, observa-se, no Quadro 4, que o roteiro utilizado induziu a delimitação em faixas etárias, que não equivalem à forma de descrição das fases da vida no mundo indígena rio-negrino. Somente por ocasião do levantamento das designações nativas para as fases da vida foi possível observar que essas eram classificadas de modo diferente do que habitualmente se usa no campo da saúde, conforme se observa no Quadro 5. Além disso, a delimitação de cada fase feita pelos estudantes evidenciou que os marcadores de cada uma delas envolvem tanto características biológicas quanto sociais; estas últimas claramente relacionadas ao desenvolvimento (ou perda) de habilidades sociais que cada pessoa vai construindo (ou perdendo) ao longo da vida.

Todos os grupos foram capazes de identificar uma série de práticas de autoatenção específicas por etnia em cada momento da vida. Uma estratégia importante para identificar 
e reconhecer as concepções próprias de cada grupo étnico sobre a autoatenção consistiu em propor aos discentes que identificassem e explicassem, em língua indígena, palavras que expressassem as noções de cuidado e suas dimensões de assistência, promoção e prevenção, conforme apresentado no Quadro 6. Em caso de inexistência de noção equivalente, os estudantes foram orientados a construir o conceito em língua indígena.

\section{Quadro 6 - Construção de conceitos sobre cuidado Polo Alto e Médio Rio Içana, subgrupo Koripaco}

Imatsietaakakhetti (promoção): Nhahi panaithanipe matsiakarotsa paowhakawa phaa inaikinai (coisas que a gente faz para não pegar doenças em todas as comunidades).

Padaanataka-shoopa (prevenção): Panaithanipe ñamekarotsa paokataa iyamikatti, likaonadapekaotsa liahi ipoatti (o que a gente faz para não acontecer ou para evitar aquele tipo de doença).

Ikapakhetti (assistência): Panaithaka pakitsindatashopa apada hiiraphittakada ipoatti sho wadee mathinaaphakani (uma maneira de ajudar uma pessoa que já está doente ou que está sofrendo uma doença para evitar que piore).

Acervo CTACIS (2009-2015).

As informações sobre cuidados na infância foram obtidas em diferentes densidades, de acordo com a possibilidade de se contar com a presença de conhecedores locais e com o conhecimento prévio dos alunos. Esses relatos eram feitos em língua indígena, e traduzidos pelos alunos para o corpo docente. Para exemplificar, um pequeno trecho de informação apresentada no curso em língua indígena e traduzida por um aluno durante as atividades do Polo Alto e Médio Içana e Aiari:

Ele [o conhecedor tradicional] falou sobre que cuidado pode ser dado às crianças, e falou sobre a formação dos seres para nós baniwa. No início o mundo era formado por quatro pessoas: Ñapirikoli, Dzooli, Mawirikoli e Eeri. Esses foram as primeiras pessoas; nossos avós. Desde aí que começaram os cuidados. Ele disse que no começo do mundo foi Ñapirikoli que engravidou a tia dele, a Amaro; ela teve um filho chamado Kowai. E esse filho fez a mãe dele sentir muita dor. (...) Eles são nossos auôs. Ele disse do cuidado que a mulher tem que ter com seu bebê; tem que ter muito cuidado com tudo, com a comida, e com depois que tem parto. Isso tudo é para não ter doença. Desde pequeno quando o bebê nasce vem o cuidado, por isso a mãe não pode comer [certos animais] quando a criança é bem novinha. A mãe tem que se cuidar, mas o marido também. $O$ bebê não pode se alimentar logo; primeiro tem que ser amamentado. Para alimentar a criança bebezinha quando ela já começa comer algumas coisas, pode dar piaba. Só que vem processo de benzimento antes dele comer; no começo é só piaba, caldo e mandioca que pode ser dado para criança. Agora, se não obedecer às regras a doença vai acontecer mesmo. É por isso é que tem de fazer a dieta tradicional; é obrigado a fazer. (Trecho relatório Polo Formativo Alto e Médio Rio Içana e Aiari) 
Alguns desafios no desenvolvimento dessa atividade se relacionaram ao fato de que esses conhecimentos não representavam novidade para os alunos, e quando entrevistavam moradores locais, em parte em razão das diferenças étnicas, as informações levantadas podiam ser bem diferentes das experiências próprias. Além disso, a diversidade étnico-linguística da turma também dificultou o aprofundamento das discussões para todos os grupos.

As entrevistas com moradores locais sobre a saúde das crianças e as conversas com os velhos conhecedores também indicaram o entendimento indígena sobre fatores de risco e principais problemas de saúde das crianças. No intuito de reforçar que a organização do trabalho em saúde deve considerar a perspectiva da comunidade, os alunos foram solicitados a organizar uma reunião comunitária para conversar sobre a situação de saúde das crianças e os principais problemas de saúde. Eles formularam as perguntas guia para a discussão e organizaram uma refeição comunitária após a qual seria realizada a conversa com as famílias. A discussão foi conduzida em língua indígena local, sendo posteriormente traduzida para o português. Apresentamos a seguir as perguntas e respostas da atividade (Quadro 7) desenvolvida no Polo Formativo Rio Xié, Baixo Rio Içana e Alto Rio Negro:

\section{Quadro 7 - Perguntas e respostas de comunidade sobre saúde das crianças}

O que as crianças precisam para crescer bem, com saúde?

Não deixar a criança suja. Não deixar a criança passar fome. Ela tem que estar bem alimentada, mas também não pode dar comida demais. Tem que diferenciar a comida da criança daquela do adulto, ou seja, fazer comida separada. A panela da comida tem que estar tampada. Uma questão importante é que as vezes a mãe vai para roça e é a irmã ou irmão mais velho que fica em casa cuidando; aí a criança pequena não se alimenta bem.

Como está a alimentação das crianças da comunidade? Elas têm boa alimentação?

Tem falta de peixe, mas nunca falta farinha e beiju. Às vezes tem almoço, mas não tem jantar. Falaram ainda que não é possível comparar a dieta e as refeições que se fazem na cidade com o que acontece na comunidade, por conta da diferença de alimentos e dos horários de comer. Entendem que o leite materno é saudável, mas a introdução do leite industrializado dá uma certa fraqueza; como prova alegam que as doenças começam a aparecer quando a criança muda do leite materno para o leite em pó comprado na cidade.

De que tipo de doenças as crianças mais adoecem nessa comunidade?

Diarreia, vômito, gripe e pneumonia.

O que poderia ser feito para melhorar a saúde das crianças e evitar as doenças?

Melhorar o tratamento do lixo; queimar o lixo, e fazer isso bem longe da comunidade. Cuidar das fraldas das crianças.

Acervo CTACIS (2009-2015). 
Os alunos desenvolveram bem essa atividade, no geral, e relataram como aspecto positivo e novo a possibilidade de realizar uma atividade comunitária para escutar os moradores. Ao longo das atividades do curso, foi possível perceber que os AIS tendem a aprender sobre as práticas educativas observando os demais profissionais da saúde das equipes. Porém, o mais comum é que os demais profissionais da saúde se limitem a realizar palestras nas quais prevalece uma perspectiva biomédica e uma pedagogia de transmissão de conhecimentos.

Destacamos alguns aspectos das respostas da reunião comunitária apresentada no Quadro 7. O primeiro é que o tema da higiene foi recorrente. Essa preocupação é compartilhada por indígenas e ocidentais, ainda que cada uma dessas sociedades desenvolva concepções, regras, valores e significados próprios, subjacentes à questão da higiene. Numa perspectiva crítica, precisamos considerar que o higienismo é uma das práticas mais consolidadas na saúde pública e na educação em saúde, e que desde os primeiros postos do Serviço de Proteção ao Índio (SPI), a preocupação dos não indígenas com a higiene dos indígenas tem sido recorrente e persistente nas diferentes iniciativas de atuação do Estado junto a esses povos, de forma que eles já reproduzem o discurso higienista entre si e com os brancos. Entretanto, recomendações como a de manter as panelas tampadas não se devem, na perspectiva rio-negrina, à preocupação com contaminação por microrganismos e sim à prevenção contra feitiçarias.

Outro ponto a destacarmos dessas conversas comunitárias é a importância de reconhecermos que as práticas alimentares são distintas em termos de horários e regularidade nas comunidades indígenas. Na região do Alto Rio Negro é comum observarmos uma frequência de refeições reduzida em comparação com a do meio urbano; trata-se de um ritmo alimentar congruente com a jornada rural de trabalho. Isso não contradiz o fato de os indígenas comumente relatarem períodos de carência alimentar. Também destacamos que a própria noção de família é diferente da urbana, e que, portanto, a responsabilidade pelos cuidados das crianças envolve mais pessoas do que ocorre nas famílias nucleares.

Por meio dessas atividades, exercitamos a escuta das narrativas indígenas sobre a infância e cuidados com as crianças e observamos detalhes e características que variam em cada região. Essas experiências reforçaram na equipe de professores a importância de se levar em conta as práticas de autoatenção para organizar, de forma complementar, as ações de saúde realizadas pelos AIS em consonância com outros membros da equipe multidisciplinar.

A atividade da reunião comunitária serviu também para debatermos sobre o processo de definição de prioridades no trabalho em saúde. Utilizando o exemplo do 
Quadro 7, destacamos que aquela comunidade priorizou como solução para os problemas de saúde a melhoria da coleta de lixo, e as equipes multidisciplinares tendiam a não incluir esse ponto como prioridade de ação naquela região.

Os AIS também foram questionados sobre suas perspectivas acerca dos fatores de risco e problemas de saúde prioritários para a saúde das crianças. Numa primeira abordagem do tema, as diretrizes Pnaisc foram apresentadas como as prioridades adotadas pelos gestores e serviços de saúde. Esse debate buscava apontar a existência de diversos pontos de vista na eleição de prioridades em saúde e a importância de envolver os diferentes atores e na definição e organização das ações de saúde. Esse também foi o mote para contextualizar que o curso iria apresentar conteúdos que expressassem prioridades estabelecidas pelas políticas públicas de saúde e de APS, mas sempre em consonância com aquelas reconhecidas nas comunidades.

Ainda para aprofundar o debate sobre a infância, principalmente quanto aos aspectos sociais e o desenvolvimento infantil, utilizou-se em algumas turmas o filme Das crianças Ikpeng para o Mundo (Vídeo nas Aldeias, 200 I). Com base no debate sobre as diferenças e semelhanças das vivências apresentadas no filme, solicitava-se que os alunos escrevessem e conversassem sobre o cotidiano das crianças nas suas comunidades. Essas informações visavam construir um olhar sobre o crescimento e desenvolvimento saudável a partir do ponto de vista indígena.

Anteriormente havia sido solicitado que os estudantes desenvolvessem pesquisas acerca dos cuidados tradicionais, familiares e comunitários na infância, em suas comunidades de residência durante a fase de dispersão. Tais informações foram retomadas para subsidiar a discussão sobre saúde da criança. Os produtos de pesquisa dos estudantes deixaram evidente a existência de um enorme conjunto de cuidados tradicionais dirigidos às crianças. Esses resultados foram discutidos com os AIS, estimulando-os a valorizar tal conjunto de conhecimentos e práticas locais, bem como a apresentar alguns deles aos demais membros da equipe multidisciplinar que atua no DSEI.

A partir dessa contextualização da infância indígena e dos cuidados tradicionais, discutiu-se sobre os cuidados à infância realizados nos serviços de saúde do DSEI. O primeiro tema abordado foi a puericultura entendida como o acompanhamento do crescimento e desenvolvimento da criança. A principal ação de puericultura que se considerou compatível com o perfil de atuação dos AIS foi o monitoramento do peso e estatura (antropometria) para realizar a avaliação nutricional das crianças (vigilância alimentar e nutricional), além do acompanhamento do aprazamento vacinal.

Os conceitos e técnicas relativos à antropometria e à vigilância nutricional foram discutidos com os alunos por meio de vídeos, aulas expositivas e leitura de textos. 
Além da dimensão teórica, foram realizadas aulas demonstrativas, e em seguida, aulas práticas na comunidade acerca das técnicas de aferição do peso e comprimento/estatura das crianças, preenchimento das curvas antropométricas do cartão/caderneta da criança, classificação nutricional e preenchimentos dos formulários do Sisvan. Para as aulas desses conteúdos, contamos com a participação de enfermeiros e nutricionista do DSEI Alto Rio Negro, pois desejávamos que os AIS conhecessem melhor esses profissionais e obtivessem as mesmas recomendações dos demais membros das equipes.

Os AIS puderam praticar essas atividades em mutirões nas comunidades onde ocorriam as aulas do curso. Essas atividades foram entendidas como oportunidade de treinamento prático, mas tiveram também a finalidade de demonstrar para os comunitários as novas atribuições dos AIS. O preenchimento do cartão/caderneta da criança e mapa diário do Sisvan eram exercitados regularmente, para que progressivamente ganhassem confiança e habilidade no manejo deles.

Outra estratégia didática por meio da qual se verificava com facilidade a consolidação dos novos conhecimentos eram as dramatizações, nas quais os AIS eram solicitados a simular os procedimentos aprendidos. Os resultados eram comentados pelos colegas e professores. As dramatizações também eram momentos ricos para a apreensão das posturas e dimensões relacionais dos AIS com os demais membros das equipes e com a comunidade.

No decorrer da abordagem desses conteúdos, foram entregues para os AIS fitas métricas, antropômetros e balanças. Os materiais impressos como cartão/caderneta da criança e fichas do Sisvan foram distribuídos para uso em sala de aula, porém seu fornecimento era de responsabilidade do DSEIRN, o que não ocorreu com a regularidade necessária. Tal circunstância obrigou o curso a ofertar os impressos para o desenvolvimento dessas atividades na comunidade nas fases de dispersão.

Consideramos importante informar que atenção especial precisou ser dada ao cálculo da idade em anos, meses e dias de vida das crianças. Essa tarefa envolveu o reconhecimento de que, naquele contexto cultural, esse tipo de informação não tem importância na vida social cotidiana, dificultando o domínio do assunto pelos estudantes. Muitos exercícios para treinamento do cálculo da idade das crianças foram necessários para consolidar o aprendizado. Constatou-se também que a atividade exigia destreza na realização de operações aritméticas, tornando-se necessária uma suplementação de aulas de matemática, o que foi feito pelos professores indígenas das comunidadessede do curso. Com o tempo, os AIS foram se familiarizando e ganhando confiança na realização dos cálculos. 
Outra dimensão importante da puericultura era a vigilância alimentar, e, considerando que a alimentação é uma prática cultural específica, para se discutir as recomendações alimentares a serem desenvolvidas pelos AIS, houve a necessidade de coletar informações sobre oferta, disponibilidade, produção de alimentos e acesso a alimentos industrializados. Esse trabalho, realizado em momento anterior no âmbito da temática de vigilância alimentar e nutricional, foi retomado nas discussões sobre cuidado à saúde da criança e complementado com outras informações específicas necessárias.

Como exemplo podemos citar o produto de entrevistas com mulheres sobre amamentação e alimentação das crianças menores de 5 anos. As respostas demonstraram que as recomendações do MS e da Sesai precisam ser especificadas em cada contexto indígena. As orientações alimentares para as crianças precisam ser construídas localmente, pois a disponibilidade e oferta alimentar diferem em cada comunidade, assim como as regras sobre alimentação infantil, regularidade e frequência de consumo. Também é importante salientar que as mulheres naquela região não relataram problemas com amamentação, e foram ressaltados, pelas informantes indígenas, diversos cuidados e orientações alimentares que as mães devem seguir nesse período. A abordagem da amamentação precisa ser diferente daquela adotada em contexto urbano.

Considerando estudos prévios sobre perfil nutricional das crianças disponíveis para a região do Alto Rio Negro, tínhamos a preocupação de abordar dois problemas nutricionais recorrentes: o baixo peso/desnutrição e a desidratação/diarreia. A equipe discutiu muito sobre como abordar essas temáticas, uma vez que já tinham sido tratadas em diversos treinamentos anteriores, gerando a reclamação contra a repetição de assuntos. Assim, optou-se por não reprisar conteúdos já trabalhados e focar a discussão nos desafios relacionados à abordagem desses problemas no trabalho cotidiano dos AIS.

Com relação à temática da desnutrição/baixo peso, percebemos que o desafio era a construção da ideia de que o baixo peso/desnutrição - tão recorrente que se torna socialmente invisível - deveria ser tomado como problema de saúde. Antes do curso, os dados de acompanhamento de peso eram preenchidos no cartão/caderneta da criança e no mapa diário do Sisvan pelos enfermeiros; como esses dados não eram discutidos com os AIS, estes não tinham acesso a tais diagnósticos. O aprendizado das técnicas de classificação da situação nutricional permitiu que os AIS identificassem que o problema do baixo peso/desnutrição existia nas suas comunidades. A constatação da abrangência desse problema deixou os AIS muito mobilizados, principalmente em relação a detectar suas causas e preveni-las. Ao fim, esses profissionais estavam muito motivados para a realização da pesagem, medida de comprimento/estatura e classificação nutricional das crianças, mas durante todo o processo identificaram dificuldades em compreender 
e discutir com as comunidades os motivos que justificavam a necessidade de tomada mensal dessas medidas. A importância da regularidade na aferição antropométrica era assunto constante nas aulas, e concluiu-se que as estratégias deveriam ser adequadas para cada contexto local.

Com relação à diarreia, um dos problemas mais frequentes nas crianças, percebemos que a ênfase deveria ser dada na avaliação da gravidade da desidratação e no desenvolvimento de estratégias mais claras sobre como abordar cada caso. Os estudantes tinham uma ideia abrangente sobre diarreia e desidratação, mas tinham dificuldade em distinguir entre graus de gravidade da desidratação e em tomar medidas de correção. O eixo guia do debate sobre esse tema foram as recomendações da Secretaria de Vigilância em Saúde no cartaz "Manejo do paciente com diarreia" (Disponível em: <http://bvsms.saude.gov.br/bvs/cartazes/manejo_paciente_diarreia_ cartaz.pdf >), adotado pelo DSEIRN. Esse plano de manejo da diarreia propõe quatro passos denominados "observe", "explore", "decida" e "trate"; e, para proceder à classificação da gravidade da diarreia, utiliza as seguintes classificações "não tem sinais de desidratação", "tem desidratação" e "tem desidratação". Com base nessa classificação, implementa-se um plano adaptado para os AIS, conforme indicado no Quadro 8.

Quadro 8 - Síntese do “Manejo do paciente com diarreia” adaptado para os AIS

\begin{tabular}{|l|l|l|}
\hline Plano A & Plano B & Plano C \\
\hline $\begin{array}{l}\text { Criança com diarreia sem } \\
\text { desidratação }\end{array}$ & $\begin{array}{l}\text { Criança com diarreia e } \\
\text { desidratação }\end{array}$ & $\begin{array}{l}\text { Criança com diarreia e } \\
\text { desidratação grave }\end{array}$ \\
\hline $\begin{array}{l}\text { Ensinar o responsável a } \\
\text { reconhecer os sinais de } \\
\text { desidratação e recomendar } \\
\text { que, em caso de piora, inicie } \\
\text { a administração de SRO e } \\
\text { procure novamente o AIS. }\end{array}$ & $\begin{array}{l}\text { A criança com desidratação } \\
\text { deverá permanecer no } \\
\text { polo-base ou sob observação } \\
\text { do AIS até a reidratação } \\
\text { completa e retornar para } \\
\text { reavaliação, após 24 a 48 } \\
\text { horas, ou imediatamente, } \\
\text { em caso de piora. }\end{array}$ & $\begin{array}{l}\text { A criança deve ficar recebendo } \\
\text { SRO sob observação do AIS e } \\
\text { solicitar com urgência remoção } \\
\text { para o polo-base ou serviço } \\
\text { mais próximo para receber } \\
\text { reidratação parenteral. }\end{array}$ \\
\hline
\end{tabular}

Acervo CTACIS (2009-20I5).

Realizaram-se discussões de casos em sala de aula para fixar os critérios e condutas para as diferentes classificações de risco. Por fim, as informações levantadas e discutidas com os alunos e os profissionais do DSEIRN sobre desnutrição/baixo peso permitiram a construção de um conjunto de condutas orientadoras da atuação do AIS, apresentadas no Quadro 9. 


\section{Quadro 9 - Condutas para a criança com problemas nutricionais}

\begin{tabular}{|c|c|c|}
\hline Problema & Conduta Nutricional & Conduta Alimentar \\
\hline $\begin{array}{l}\text { Criança com } \\
\text { baixo peso } \\
\text { sem diarreia }\end{array}$ & $\begin{array}{l}\text { - Pesar e medir a criança de } 15 \text { em } 15 \\
\text { dias; } \\
\text { - Fazer o registro das medidas da } \\
\text { criança no cartão da criança e Sisvan; } \\
\text { - Comparar com as medidas anteriores. } \\
\text { Ver a curva que está no cartão para } \\
\text { avaliar se a criança está melhorando } \\
\text { ou piorando; } \\
\text { - Mostrar para a família os resultados } \\
\text { da avaliação e pedir reforço alimentar; } \\
\text { - Resultado positivo: animar a família } \\
\text { para continuar; } \\
\text { - Resultado negativo: adotar conduta } \\
\text { alimentar; } \\
\text { - Preencher a "Ficha de monitoramento } \\
\text { da criança de } 0 \text { a } 59 \text { meses com } \\
\text { problemas nutricionais". }\end{array}$ & $\begin{array}{l}\text { Para assistência alimentar à criança } \\
\text { desnutrida e de baixo peso } \\
\text { - O AIS deve orientar as mães e pais a } \\
\text { reforçar a quantidade de proteínas, } \\
\text { vitaminas e sais minerais da comida } \\
\text { das crianças desnutridas e com baixo } \\
\text { peso. } \\
\text { Para prevenção dos problemas } \\
\text { nutricionais } \\
\text { - Explicar para a família e para a } \\
\text { comunidade sobre os problemas } \\
\text { nutricionais existentes no território e } \\
\text { orientar a respeito dos nutrientes que } \\
\text { existem nos alimentos tradicionais } \\
\text { e dos problemas gerados pelos } \\
\text { alimentos industrializados. } \\
\text { - Fazer levantamento da alimentação } \\
\text { de cada família e da comunidade para } \\
\text { verificar o consumo de alimentos no } \\
\text { cotidiano. Neste levantamento, o } \\
\text { AIS deve procurar saber que tipos de } \\
\text { nutrientes são consumidos todos os } \\
\text { dias; quais são consumidos só de vez } \\
\text { em quando; e quais estão faltando } \\
\text { na dieta, conforme o território da } \\
\text { comunidade. } \\
\text { - Caso a comunidade aceite, cada } \\
\text { família poderia ter um terreno } \\
\text { específico para a produção de } \\
\text { alimentos, de modo a reforçar a } \\
\text { oferta de vitaminas, sais minerais e } \\
\text { proteínas para seus filhos pequenos. } \\
\text { O AIS também pode estimular a } \\
\text { rotação de colheitas para facilitar o } \\
\text { consumo de todos os nutrientes ao } \\
\text { longo do ano, priorizando as crianças } \\
\text { com baixo peso e desnutrição. }\end{array}$ \\
\hline
\end{tabular}




\section{Quadro 9 - Condutas para a criança com problemas nutricionais (continuação)}

\begin{tabular}{|c|c|c|}
\hline Problema & Conduta Nutricional & Conduta Alimentar \\
\hline $\begin{array}{l}\text { Criança com } \\
\text { baixo peso e } \\
\text { com diarreia }\end{array}$ & $\begin{array}{l}\text { - Pesar e medir a criança de } 15 \text { em } 15 \\
\text { dias, com acompanhamento diário da } \\
\text { evolução da diarreia e do peso (seguir } \\
\text { o roteiro "Avaliação da criança com } \\
\text { diarreia"); } \\
\text { - Fazer o registro das medidas da } \\
\text { criança no cartão da criança e Sisvan; } \\
\text { - Comparar com as medidas anteriores. } \\
\text { Ver a curva que está no cartão para } \\
\text { avaliar se a criança está melhorando } \\
\text { ou piorando; } \\
\text { - Mostrar para a família os resultados } \\
\text { da avaliação e pedir reforço alimentar; } \\
\text { - Fazer soro conforme "Manejo do } \\
\text { paciente com diarreia”; } \\
\text { - Resultado positivo: animar a família } \\
\text { para continuar tratamento; resultado } \\
\text { negativo: aumentar o número de } \\
\text { doses do soro oral, comunicar } \\
\text { ao polo-base e a colegas mais } \\
\text { experientes, pedir remoção e adotar } \\
\text { conduta alimentar. }\end{array}$ & $\begin{array}{l}\text { Para promoção da saúde } \\
\text { - Organizar as famílias e as } \\
\text { comunidades para melhorar a } \\
\text { qualidade e aumentar a quantidade de } \\
\text { nutrientes consumidos por crianças } \\
\text { de baixo peso, por meio de: } \\
\text { - pescaria e caçaria; } \\
\text { - criação de peixes e de galinhas; } \\
\text { - reforço à plantação de roça } \\
\text { para alimento da família e para } \\
\text { alimentar animais de criação; } \\
\text { - reforço à plantação de fruteiras, } \\
\text { na roça e na comunidade. } \\
\text { - Estimular: } \\
\text { - No verão, para as comunidades } \\
\text { de terra arenosa: a pescaria, a } \\
\text { caçaria e a plantação de caju, } \\
\text { abacaxi, coco, açaí, ingá, manga, } \\
\text { pupunha, cucura, banana e } \\
\text { pimenta. }\end{array}$ \\
\hline $\begin{array}{l}\text { Criança } \\
\text { com muito } \\
\text { baixo peso } \\
\text { (desnutrição) } \\
\text { sem diarreia }\end{array}$ & $\begin{array}{l}\text { - Pesar e medir a criança de } 7 \text { em } 7 \\
\text { dias; } \\
\text { - Fazer o registro das medidas da } \\
\text { criança no cartão da criança e Sisvan; } \\
\text { - Comparar com as medidas anteriores. } \\
\text { Ver a curva que está no cartão para } \\
\text { avaliar se a criança está melhorando } \\
\text { ou piorando; } \\
\text { - Mostrar para a família os resultados } \\
\text { da avaliação e pedir reforço alimentar; } \\
\text { - Resultado positivo: animar a família } \\
\text { para continuar; resultado negativo: } \\
\text { adotar conduta alimentar. }\end{array}$ & $\begin{array}{l}\text { caçaria e a plantação de abacaxi, } \\
\text { cará, cana, banana, abóbora, } \\
\text { cubiú, batata doce, pupunha, } \\
\text { abio, banana e pimenta. }\end{array}$ \\
\hline
\end{tabular}


Quadro 9 - Condutas para a criança com problemas nutricionais (continuação)

\begin{tabular}{|l|c|c|}
\hline Problema & Conduta Nutricional & Conduta Alimentar \\
\hline Criança com & • Pesar e medir a criança de 7 em 7 & - No inverno, para as comunidades \\
muito baixo & dias, com acompanhamento diário da & de terra arenosa: a pescaria na \\
peso com & evolução da diarreia e do peso (seguir & piracema, a caçaria e a coleta \\
diarreia & a "Avaliação da criança com diarreia"); & na mata de buriti, açaí do mato, \\
& - Fazer o registro das medidas da & umari e patauá. \\
& criança no cartão da criança e Sisvan; & - No inverno, para as comunidades \\
& - Comparar com as medidas anteriores. & de terra firme: a pescaria na \\
& Ver a curva que está no cartão para & piracema, a caçaria e a coleta, \\
& avaliar se a criança está melhorando & na mata açaí do mato, bacaba, \\
& ou piorando; & patauá, ucuqui e umari. \\
& - Mostrar para a família os resultados & \\
& da avaliação e pedir reforço alimentar; & \\
& - Fazer soro conforme "Condutas para & \\
& casos de diarreia"; \\
& - Resultado positivo: animar a família & \\
& para continuar; resultado negativo: & \\
& aumentar o número de doses do & \\
& soro oral, comunicar ao polo-base & \\
e a colegas mais experientes, pedir & \\
& remoção e adotar conduta alimentar. & \\
\hline
\end{tabular}

Acervo CTACIS (2009-20I5).

Devemos destacar que encontramos dificuldades para que os AIS pudessem assumir as responsabilidades sobre antropometria e vigilância nutricional das crianças. Além dos supracitados problemas com fornecimento de equipamentos e formulários pelo DSEI, houve o desafio de obter anuência dos enfermeiros e técnicos de enfermagem das equipes para dividir as tarefas de vigilância alimentar com os AIS. Percebemos que havia uma desconfiança com relação à qualidade do trabalho dos AIS, mas também pouco interesse em apoiá-los e estimulá-los para a melhoria das suas habilidades e aumento da confiança na execução dessas ações. Embora a coordenação do curso realizasse reuniões periódicas com a gerência do DSEI, com os próprios profissionais das equipes, e distribuísse os roteiros e textos utilizados nas aulas, percebemos haver uma disputa de espaço e de poder de algumas categorias profissionais que relutavam em descentralizar algumas tarefas para os AIS, sob a alegação - etnocêntrica - de que os indígenas não seriam capazes de executar atividades técnicas de saúde. Em contrapartida, uma vez familiarizados com o manejo correto das técnicas de antropometria e o preenchimento do cartão e da curva de crescimento, diversos AIS passaram a identificar erros cometidos pelos demais membros das equipes e a apontar publicamente os equívocos cometidos na realização dessas tarefas, gerando novos conflitos na relação interprofissional. 
Outro tema estratégico na organização da atenção à saúde da criança no âmbito da equipe multidisciplinar é o Programa Nacional de Imunização (PNI), visto como principal ação preventiva desenvolvida no DSEI. Para introduzir essa temática, optamos por discutir inicialmente o histórico de epidemias decorrentes do contato entre indígenas e não indígenas. Para isso, exibimos o filme Xingu (20 I I), dirigido por Cao Hamburger, que relata a trajetória dos irmãos Villas-Boas na Expedição Roncador-Xingu e a forma como nesse processo os grupos indígenas, antes isolados, sofreram várias epidemias de gripe que mataram muitos deles e desestruturaram as comunidades. Assim, o filme contextualizou e pontuou o início das atividades de vacinação nas aldeias, provocando reflexões dos alunos acerca da própria história. Para subsidiar o debate também se apresentou uma versão adaptada do texto "Contas de vidro, enfeites de branco e 'potes de malária": epidemiologia e representações de doenças infecciosas entre os desana", de Dominique Buchillet (1995) acerca do histórico das epidemias na região do Alto Rio Negro.

Além da dimensão histórica e social do contexto das epidemias, havia a preocupação em apresentar um sumário do mecanismo de ação das vacinas e o PNI, visando subsidiar o trabalho do AIS nas atividades educativas com as comunidades. Como estratégia para essa discussão foram utilizados vídeos, imagens e leitura de texto explicativo sobre o PNI, produzido pelos professores. A leitura do texto foi repetida várias vezes no intuito de esclarecer palavras desconhecidas do acervo vocabular dos estudantes.

Como forma de apropriação do tema, os alunos foram convocados a produzir cartazes explicativos para as comunidades, em línguas indígenas, versando sobre vacinação. Essas atividades mostraram a dificuldade do processo de traduzir informações técnicas para o linguajar cotidiano. O desenvolvimento da tarefa permitiu perceber que os AIS tenderam a escolher a estratégia de aula expositiva ou palestra, com adoção de muitos termos técnicos que dificultariam a compreensão do tema pelos comunitários. Além disso, percebemos que os AIS imitaram algumas estratégias moralistas e aterrorizantes presentes nas práticas dos profissionais da saúde. Tais problemas foram devidamente sanados, mas sua ocorrência alertou a coordenação do curso para a importância de discussões mais aprofundadas sobre práticas de educação em saúde.

Pretendíamos também que os AIS aprendessem a verificar o registro vacinal no cartão/ caderneta da criança, no intuito de apoiar o restante na equipe no planejamento das atividades de vacinação e monitoramento dos atrasos vacinais. Para isso, foi explicado como deveria ser feito o registro de vacinação no cartão e apresentado o calendário vacinal específico para as crianças indígenas. Esse conteúdo foi praticado por meio da construção de calendário em cartaz conforme (Quadro 10), com campos removíveis. 
Quadro 10 - Aprazamento vacinal para crianças indígenas, normativa PNI de 2013

\begin{tabular}{|c|c|c|c|c|c|c|c|}
\hline \multicolumn{5}{|c|}{ Vacinas obrigatórias no $I^{\circ}$ ano de vida } & \multirow{2}{*}{$\begin{array}{l}\text { Febre- } \\
\text { amarela }\end{array}$} & \multicolumn{2}{|c|}{ Outras vacinas } \\
\hline Antipólio & Tetra & Hepatite B & BCG & Tríplice viral & & Rotavírus & Pneumolo \\
\hline 2 meses & 2 meses & Ao nascer & Ao nascer & $\begin{array}{l}I^{\text {a dose }} \\
\text { I ano }\end{array}$ & 9 meses & $\begin{array}{l}I^{a} \text { dose } \\
2 \text { meses }\end{array}$ & $\begin{array}{l}I^{\mathrm{a}} \text { dose } \\
2 \text { meses }\end{array}$ \\
\hline 4 meses & 4 meses & $\begin{array}{l}30 \text { dias } \\
\text { após a I a } \\
\text { dose }\end{array}$ & & $\begin{array}{l}2^{a} \text { dose } \\
4-6 \text { anos }\end{array}$ & $\begin{array}{l}\text { Varicela } \\
\text { I ano }\end{array}$ & $\begin{array}{l}\text { Rotavírus } \\
2^{\text {a }} \text { dose } \\
4 \text { meses }\end{array}$ & $\begin{array}{l}\text { Pneumol0 } \\
2^{\text {a }} \text { dose } \\
4 \text { meses }\end{array}$ \\
\hline 6 meses & 6 meses & 6 meses & Gripe & & $\begin{array}{l}\text { Pneumo23 } \\
2 \text { anos }\end{array}$ & $\begin{array}{l}\text { Pneumo I } 0 \\
\text { Reforço } \\
15 \text { meses }\end{array}$ & $\begin{array}{l}\text { Pneumol0 } \\
3^{\mathrm{a}} \text { dose } \\
6 \text { meses }\end{array}$ \\
\hline 15 meses & $\begin{array}{l}\text { DTP } \\
1^{\circ} \text { reforço } \\
\text { I } 5 \text { meses }\end{array}$ & $\begin{array}{l}\text { DTP } \\
2^{\circ} \text { reforço } \\
4-6 \text { anos }\end{array}$ & & & $\begin{array}{l}\text { MNGC } \\
\text { Reforço } \\
\text { I5 meses }\end{array}$ & $\begin{array}{l}\text { MNGC } \\
\text { I }^{\text {a dose }} \\
3 \text { meses }\end{array}$ & $\begin{array}{l}\text { MNGC } \\
2^{\mathrm{a}} \text { dose } \\
5 \text { meses }\end{array}$ \\
\hline
\end{tabular}

Acervo CTACIS (2009-20I5).

As rotinas de vacinação também foram dramatizadas em sala de aula para debate, pedindo-se tanto para demonstrar como foram realizadas as atividades de vacinação nas comunidades nos últimos anos quanto para levantar a opinião dos AIS sobre como deveria ser a rotina de vacinação nas comunidades e como eles poderiam atuar. Essa atividade foi extremamente rica para percebermos como costumava ser a inserção dos AIS nas equipes e quais eram as expectativas acerca de seu novo papel. Na dramatização sobre a forma como as equipes vinham atuando nas atividades de vacinação, os AIS, destacaram que essas atividades não eram pactuadas com as comunidades antecipadamente; sua realização era apressada e havia falta de material. Aos AIS eram atribuídos somente serviços gerais, como carregar caixas e organizar o espaço para o trabalho dos enfermeiros.

A seguir apresentamos o relato feito pelos alunos do Polo Rio Xié, Baixo Içana e Alto Rio Negro, que expressa as ideias dos estudantes sobre como realizar uma boa vacinação:

Primeiro a equipe passa na comunidade somente para entregar um cronograma no qual consta a data em que eles passarão naquela comunidade para fazer a vacinação. Após isso a AIS passa de casa em casa avisando a visita da equipe. Quando a equipe chega fornece os mapas Sisvan, se apresentam, a enfermeira conversa sobre a importância da vacinação. Eles se mostram disponíveis para outros problemas que as pessoas da comunidade querem tratar, dando prioridade aos pacientes graves, perguntando, por exemplo, sobre outras condições de saúde a lém da situação vacinal. A atuação do AIS foi muito importante neste grupo, ele fez 
uma boa ligação entre equipe e comunidade; também conversou com a equipe, indicando as situações mais problemáticas, falando das pessoas que estão sem vacinas e indicando quais vacinas estão faltando. (relatório curso CTACIS, polo Baixo Rio Negro).

Observa-se nesse relato que os alunos destacaram a importância da pactuação com as comunidades para o desenvolvimento das atividades, a abertura a múltiplas demandas da população e uma atuação ativa do AIS no planejamento e execução das ações de saúde.

Em razão da alta prevalência de IRA e de os dados indicarem a pneumonia como uma das principais causas de morte em crianças indígenas menores de 5 anos, consideramos fundamental abordar essa temática. Novamente, trata-se de problema de saúde muito familiar aos AIS e que já havia sido abordado em outros treinamentos. Entretanto, se observava pouca clareza sobre como identificar uma criança com suspeita de pneumonia. Dessa forma, fez-se uma abordagem ampla das IRAs, com discussão acerca das vias aéreas superiores e esclarecimento sobre as formas de transmissão e prevenção das IRAs. Os AIS foram ensinados a contar a frequência respiratória das crianças e a identificar tiragem subcostal, pois esses são os principais sinais clínicos para suspeita de pneumonia. Adotaram-se as recomendações do MS para critérios de suspeita de pneumonia e condutas para os AIS, apresentadas no Quadro II.

\section{Quadro II - Critérios para classificar casos de IRA e suspeita de pneumonia}

\begin{tabular}{|c|c|c|c|}
\hline Idade & $\begin{array}{l}\text { IRA não } \\
\text { pneumonia }\end{array}$ & Suspeita de pneumonia & Suspeita de pneumonia grave \\
\hline $\begin{array}{l}\text { Menor de } 2 \\
\text { meses }\end{array}$ & \multirow{3}{*}{$\begin{array}{l}\text { Sem tiragem } \\
\text { subcostal } \\
\text { e sem } \\
\text { respiração } \\
\text { rápida para a } \\
\text { idade }\end{array}$} & $\varnothing$ & $\begin{array}{l}\text { Respiração rápida para idade } \\
\text { ( } \geq 60 \mathrm{rpm} \text { ) e/ou tiragem } \\
\text { subcostal }\end{array}$ \\
\hline $\begin{array}{l}\text { De } 2 \text { a II } \\
\text { meses }\end{array}$ & & $\begin{array}{l}\text { Respiração rápida para idade } \\
\text { ( } \geq 50 \mathrm{rpm} \text { ) sem tiragem } \\
\text { subcostal }\end{array}$ & $\begin{array}{l}\text { Respiração rápida para } \\
\text { idade ( } \geq 50 \mathrm{rpm}) \text { e tiragem } \\
\text { subcostal }\end{array}$ \\
\hline De I a 4 anos & & $\begin{array}{l}\text { Respiração rápida para idade } \\
\text { ( } \geq 40 \mathrm{rpm} \text { ) sem tiragem } \\
\text { subcostal }\end{array}$ & $\begin{array}{l}\text { Respiração rápida para } \\
\text { idade ( } \geq 40 \mathrm{rpm}) \text { e tiragem } \\
\text { subcostal }\end{array}$ \\
\hline Conduta & $\begin{array}{l}\text { Sintomáticos } \\
\text { em casa }\end{array}$ & Encaminhar ao polo-base & $\begin{array}{l}\text { Remoção imediata para } \\
\text { polo-base ou sede DSEI }\end{array}$ \\
\hline
\end{tabular}

Acervo CTACIS (2009-20I5).

O último tema que a equipe da coordenação do curso, em conjunto com profissionais e gestores do DSEIRN, inseriu na abordagem do cuidado à saúde das crianças foi a estratégia denominada Atenção Integrada às Doenças Prevalentes na Infância (AIDPI). 
Esse programa foi desenvolvido e disseminado pela OMS, e havia sido adotado pelo MS e pela Sesai. Entretanto, na implantação do AIDPI nos DSEI não houve o treinamento de todos os profissionais médicos e de enfermagem, e, principalmente, não se discutiu a inserção dos AIS. Apesar disso, considerou-se relevante a qualificação dos AIS nessa estratégia, pois na região do Alto Rio Negro, em razão das grandes distâncias e frequentes ausências dos demais membros da equipe, os AIS são o primeiro contato das crianças doentes com os serviços. São eles que fazem o primeiro atendimento e avaliação de risco das crianças, porém até aquele momento o faziam sem critérios claros e padronizados.

Para introduzir a importância do AIDPI na atuação dos AIS, inicialmente se discutiu com os alunos a situação da mortalidade infantil na região do Alto Rio Negro, cujos dados mostravam a alta prevalência de diarreia e IRA, e mortalidade elevada por pneumonia. Com base nesses dados, se problematizaram as causas da mortalidade infantil na região, levantando-se aspectos culturais, de saneamento, de cuidados familiares, de ações de saúde, de recursos territoriais, entre outros.

Como alguns médicos e enfermeiros do DSEIRN haviam sido treinados no AIDPI, um desses médicos foi incorporado na equipe do curso e, em conjunto com a coordenação, preparou uma adaptação do material do MS sobre a AIDPI para os AIS. Foram adaptadas as instruções das etapas e os formulários, de modo a facilitar a compreensão e utilização pelos AIS. A equipe fez uma simplificação e síntese da estratégia AIDPI e de seus passos da seguinte forma:

Passo I - Sinais gerais de perigo

- Não bebe ou não consegue mamar.

- Vomita tudo o que ingere.

- Apresenta ou apresentou convulsões.

- Está letárgica (molinha, não reage aos estímulos) ou inconsciente (desacordada, desmaiada).

Passo 2 -Sintoma principal: tosse

- Perguntar: há quanto tempo? Mais de 14 dias?

- Verificar: frequência respiratória, tiragem subcostal e estridor. 
PASSO 3 - Sintoma principal: diarreia

- Perguntar: há quanto tempo? Mais de 14 dias? Tem sangue?

- Verificar:

- Condição geral

- Letargia/inconsciência

- Agitação/irritação

- Olhos fundos

- Sinal da prega

- Muito lentamente

- Lentamente

- Como bebe: não bebe ou bebe com muita vontade

PAsso 4 - Sintoma principal: febre

- Perguntar: esteve nos últimos trinta dias em área de risco para malária? Está com febre há quanto tempo?

- Verificar:

- Rigidez da nuca

- Petéquias

- Fontanela abaulada

Na abordagem do AIDPI, o primeiro ponto foi a verificação de sinais vitais, os alunos aprenderam a verificar a frequência respiratória, pulso e temperatura, o que foi feito com demonstração e prática entre os alunos e com filhos(as) deles, quando possível. Em seguida seguimos a sequência proposta pelo próprio treinamento do AIDPI usando os vídeos disponibilizados por ele. Exibimos os vídeos em conjunto com a leitura dos roteiros produzidos, revisando várias vezes e discutindo cada ponto. Os casos apresentados nos vídeos para exercício foram fundamentais para os alunos praticarem e ganharem maior confiança. Também se desenvolveram exercícios de estudo de casos propostos pelos professores para discutir a classificação de risco das crianças, e dramatizações para verificar a apreensão dos alunos da sequência de perguntas proposta pelo AIDPI. Consideramos que, apesar das dificuldades iniciais, ao fim, os AIS tiveram um bom manejo dos formulários e das classificações do AIDPI, nos mostrando que existe a possibilidade de utilizarem ferramentas específicas do campo da saúde. 
A estratégia AIDPI também se mostrou interessante para revisar e articular os diversos conteúdos abordados como avaliação de estado nutricional e de desidratação e aprazamento vacinal. Outro ponto importante foi a padronização nos critérios e termos para a avaliação de risco das crianças, relatado como um facilitador da comunicação entre os AIS nas comunidades e os enfermeiros e médicos das equipes multidisciplinares.

Após a abordagem de todos os temas, a discussão sobre o cuidado à saúde da criança indígena foi finalizada com a discussão das novas atribuições dos AIS nesse âmbito. Durante todo o processo de discussão curricular, sempre buscamos ressignificar a visita domiciliar, pois os AIS tinham pouca clareza sobre seus objetivos, que no geral ficavam resumidos a identificar pessoas com queixas agudas. Dessa forma, a equipe de coordenação do curso se esforçou para construir roteiros de visita domiciliar para as áreas de atuação do AIS. Ao fim de cada bloco temático, se fazia a leitura e debate dos roteiros produzidos, e dramatização para se discutir a viabilidade dele. Este processo é exemplificado no fim deste capítulo pela apresentação do "Roteiro de visita domiciliar do AIS em saúde da criança”, no qual focamos principalmente a vigilância alimentar e nutricional e o acompanhamento vacinal das crianças. Também se pontuaram ações a serem desenvolvidas pelos AIS no âmbito comunitário para a promoção da saúde e prevenção de doenças, e se destacaram algumas atribuições do restante da equipe multiprofissional em saúde indígena.

Para finalizar o capítulo, gostaríamos de ressaltar que esse conjunto de temas e abordagens foi possível por uma articulação próxima entre a equipe do curso e os profissionais da saúde do DSEIRN. Entretanto, apesar dessa proximidade durante o curso, em razão da alta rotatividade dos profissionais do DSEIRN, muitos dos novos profissionais das equipes e da nova gestão não mantiveram os AIS estimulados e apoiados para implementar as ações de saúde.

EXEMPLO I: ROTEIRO de VISITA DOMICILIAR DO AIS EM SAÚdE DA CRIANÇA

I. "Bater na porta” e pedir autorização para entrar.

2. Cumprimentar as pessoas da casa.

3. Se for oferecido algum alimento, o AIS deve aceitar e partilhar a comida.

4. Conversar um pouco para deixar as pessoas da casa à vontade. 
5. Explicar a finalidade da visita depois do novo treinamento. Explicar também:

a) Os novos procedimentos aprendidos para fazer o acompanhamento da saúde da criança (acompanhamento do crescimento, vigilância alimentar e nutricional, vacinação e atenção integral à criança doente).

b) A necessidade de assistir aos doentes, mas que também terá que acompanhar as pessoas sadias, principalmente mulheres e crianças.

6. Para acompanhamento da saúde das crianças, o AIS deve:

- Antes do início da visita:

- Identificar quantas crianças vivem na comunidade e em cada casa, através da "Ficha A" ou do caderno de capa preta.

- Identificar quem são as crianças de 0 a 5 anos de idade, que têm prioridade para atendimento em saúde da criança.

- Antes de sair para a visita, o AIS deve separar e levar todos os materiais necessários para fazer a visita: balança, fita métrica, antropômetro, "Ficha de acompanhamento da vigilância alimentar e nutricional da criança indígena pelo AIS", fichas do Sisvan, "Formulário de registro: avaliar e classificar a criança doente”, termômetro, lápis, caneta e borracha;

- Logo no início da visita o AIS deve:

- Registrar, na "Ficha de acompanhamento da vigilância alimentar e nutricional da criança indígena pelo AIS", a data de atendimento, nome da mãe e da criança, data de nascimento, e calcular a idade;

Esses procedimentos devem ser feitos para cada criança visitada, dentro da faixa prioritária, independentemente de elas estarem doentes ou não.

EXEMPLO 2: ROTEIRO DE PROCEDIMENTOS DE AVALIAÇÃO DE CRIANÇAS NA VISITA DOMICILIAR

I. Recém-Nascidos

- Realizar visita domiciliar logo que a mãe tiver condições de levantar (no dia do parto ou dia seguinte do parto, de preferência) para:

- Verificar o peso, comprimento e perímetro encefálico (cabeça) da criança; 
- Preencher a Declaração de Nascido Vivo;

- Verificar coto umbilical e orientar os cuidados durante o primeiro mês, principalmente se houver sinais de inflamação como pus, vermelhidão e inchaço no coto umbilical ou na pele ao redor;

- Orientar sobre a importância da amamentação exclusiva até 6 meses;

- Orientar sobre o Cartão da Criança e o calendário vacinal a ser seguido. Revisar o cartão de vacina da mãe, verificando se a vacinação materna está completa;

- Orientar sobre a higiene oral da criança durante a amamentação;

- Informar o restante da equipe sobre os nascimentos, visando a realização da primeira consulta de puericultura e vacinação.

2. Crianças até 6 meses

- Realizar visita domiciliar mensal.

- Calcular a idade da criança em anos e meses (fazendo o arredondamento para o Sisvan).

- Verificar o peso e comprimento.

- Preencher (a lápis) o Cartão da Criança ou Caderneta da Criança, verificar a classificação nutricional e orientar a família para os casos de baixo peso e muito baixo peso.

- Preencher mapa mensal do Sisvan.

- Incentivar o aleitamento materno exclusivo.

- Verificar a situação vacinal e orientar sobre as próximas vacinas.

- Orientar sobre a higiene oral da criança durante a amamentação.

- Informar o restante da equipe sobre as crianças identificadas com muito baixo peso/baixo peso/risco nutricional e com atraso vacinal e encaminhar seus registros para revisão pela(o) enfermeira(o).

3. Crianças de 6 meses a I ano

- Realizar visita domiciliar mensal.

- Calcular a idade da criança em anos e meses (fazendo o arredondamento para o Sisvan). 
- Verificar o peso e comprimento.

- Preencher o Cartão da Criança ou Caderneta da Criança e verificar a classificação nutricional.

- Preencher mapa mensal do Sisvan.

- Verificar a situação vacinal e orientar sobre as próximas vacinas.

- Incentivar a continuidade da amamentação e orientar sobre a introdução de outros alimentos e a alimentação complementar.

- Orientar sobre a higiene oral da criança.

- Informar o restante da equipe sobre as crianças identificadas com muito baixo peso/baixo peso/risco nutricional e com atraso vacinal e encaminhar seus registros para revisão pela(o) enfermeira(o).

Obs.: Preste atenção redobrada ao estado nutricional da criança nesse período, pois a mudança de alimentação aumenta a vulnerabilidade.

4. Crianças de I a 5 anos

- Realizar visita domiciliar mensal.

- Calcular a idade da criança em anos e meses (fazendo o arredondamento para o Sisvan).

- Verificar o peso e altura/comprimento.

- Preencher o Cartão da Criança ou Caderneta da Criança e verificar a classificação nutricional.

- Preencher mapa mensal do Sisvan.

- Verificar a situação vacinal e orientar sobre as próximas vacinas.

- Incentivar a continuidade da amamentação até 2 anos.

- Orientar sobre a higiene oral da criança.

- Orientar sobre alimentos ricos em ferro, vitamina C, proteína e carboidratos, principalmente para as crianças com baixo peso ou muito baixo peso.

- Informar o restante da equipe sobre as crianças identificas com muito baixo peso/baixo peso/risco nutricional e com atraso vacinal e encaminhar seus registros para revisão pela(o) enfermeira(o). 
5. Para crianças com queixas

- Calcular a idade da criança em anos e meses.

- Verificar o peso e altura/comprimento.

- Verificar sinais vitais (temperatura, frequência respiratória, pulso).

- Solicitar o cartão da criança ou caderneta da criança para verificar a classificação nutricional e situação vacinal.

- Realizar a classificação e condutas segundo o roteiro da "Atenção Integral à Criança Doente - Estratégia de Atenção Integrada às Doenças Prevalentes da Infância (AIDPI)”.

- Informar o polo-base e sede DSEl sobre os casos graves e em observação, e encaminhar, se necessário.

O AIS não deve se recusar a ver os doentes, mas ao realizar a visita deve iniciar pelo acompanhamento das mulheres, das crianças e do Sisvan e depois buscar as queixas de doença.

Essa ordem de realização do trabalho poderá ser alterada se houver um caso de emergência no domicílio ou na comunidade.

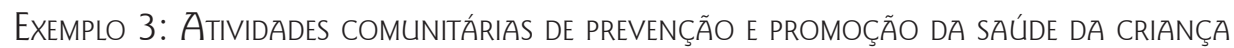
A SEREM DESENVOLVIDAS PELO AIS

- Discutir a situação de saúde das crianças, identificando os fatores de risco, situações de vulnerabilidade e problemas de saúde no ponto de vista da população e do AIS.

- Discutir a situação alimentar das crianças na comunidade, sem identificar pelo nome as crianças com baixo e muito baixo peso. Também deve discutir alternativas para melhoria da alimentação, principalmente o incentivo ao aleitamento materno e à oferta de alimentos ricos em ferro, vitamina $\mathrm{C}$ e proteínas.

- Discutir a vacinação e sua importância, o calendário vacinal e a participação da comunidade nas ações de vacinação. Apresentar os resultados alcançados nas ações de vacinação.

- Orientar sobre a higienização oral das crianças e realizar atividades coletivas de escovação. 
- Caso ocorra epidemia de alguma doença (como gripe ou diarreia/desidratação), discutir com a comunidade as medidas a serem tomadas e informar o restante da equipe do polo-base sobre essas ocorrências.

EXEMPLO 4: ResponsAbILIDADES E ATRIBUIÇõES DO RESTANTE DA EQUIPE

- Discutir com a comunidade e lideranças as ações a serem desenvolvidas por toda a equipe.

- Revisar o preenchimento da curva do crescimento no cartão da criança ou caderneta feito pelo AIS.

- Avaliar as crianças identificas pelo AIS com baixo peso e muito baixo peso e discutir as orientações e condutas com os AIS.

- Verificar e coletar os "Mapas Diários do Sisvan" preenchidos mensalmente pelo AIS.

- Discutir com as famílias e com o AIS a situação nutricional e alimentar das crianças da comunidade e as alternativas para a melhoria da alimentação.

- Discutir com o AIS e lideranças comunitárias sobre planejamento e execução das ações de vacinação.

- Realizar a vacinação das crianças.

- Discutir, presencialmente ou pela radiofonia, os casos de crianças doentes identificadas pelos AIS.

- Realizar atendimento das crianças identificadas pelo AIS como casos graves ou com necessidade de avaliação e realização de tratamento medicamentoso.

- Realizar atendimento odontológico.

- Participar, quando possível, das ações de prevenção e promoção de saúde desenvolvidas pelo AIS. 


\section{6}

\section{Dimensões da saúde do adulto: o cuidado à saúde da mulher indígena}

A abordagem da saúde do adulto não é tema recente em APS, mas existe um conjunto maior de ações direcionadas à saúde da mulher. Contudo, a revisão das rotinas de trabalho em APS no Brasil mostrou que, na temática de atenção à saúde da mulher, evidencia-se a absoluta prioridade dada à atenção materna, com ênfase em atenção pré-natal, prevenção de câncer de colo de útero, promoção do aleitamento materno e outras ações voltadas para a saúde reprodutiva, relegando a um plano secundário outras dimensões da saúde feminina.

A emergência de uma política específica para a saúde do homem é bastante recente no Brasil, pois somente em 2008 foi lançada a Política de Atenção Integral à Saúde do Homem. Suas diretrizes preconizam o desenvolvimento de ações de promoção, prevenção e proteção básica à saúde, além de prever a oferta de atenção integral e a facilitação do acesso masculino aos serviços de saúde (Brasil, 2008). Estudos (Leal et al., 2012) vêm evidenciando dificuldades na implementação dessa política em unidades de atenção básica na rede do SUS, decorrentes da fragmentação e descontinuidade nas atividades ali desenvolvidas, inclusive no que diz respeito ao cuidado dirigido à população masculina. Predomina a oferta ao atendimento de hipertensão, diabetes e à detecção precoce de câncer de próstata, mas sem uma abordagem específica de gênero e sem efetivar uma adequação às necessidades e singularidades masculinas (Leal et al., 2012).

Em resumo, o cuidado ofertado na rede de atenção básica ainda carece da amplitude demandada por uma abordagem integral da saúde do adulto. Não encontramos publicações que oferecessem um panorama da atenção à saúde do adulto e/ou do homem e da mulher indígena ofertada nos DSEI. A revisão de literatura encontrou somente publicações que refletem sobre os desafios à implantação dessa política (Ferreira, 20I3) e sobre os direitos de gênero em contextos indígenas (Coimbra E Garnelo, 2004). Desse modo, o planejamento do curso técnico profissionalizante para AIS partiu do 
pressuposto de que o cenário encontrado na rede de atenção básica ofertada aos não indígenas guarda similaridade com o perfil de atuação das equipes de saúde no DSEI onde ofertou-se o curso.

Em que pese o propósito inicial de ofertar capacitação dos AIS para uma atuação em saúde do adulto - respeitando seu perfil de atuação como técnico de nível médio -, não foi possível cumprir integralmente esse objetivo, já que a rede de atenção básica no Brasil ainda não atua de acordo com as premissas que orientam a saúde do adulto em geral e a saúde do homem em particular.

Assim, o processo formador optou por acompanhar o regime de atuação real das equipes multidisciplinares que atuam no DSEl, direcionando seus esforços para capacitar os estudantes para o desenvolvimento de atividades em saúde da mulher, enfatizando aquilo que as equipes fazem de modo mais frequente e regular, ou seja, ações de saúde reprodutiva, em particular o cuidado à gestação. Outros temas relativos à saúde do adulto, como o monitoramento das condições crônicas e de saúde do trabalhador rural foram trabalhados no processo formador, mas não serão analisados aqui.

\section{Oferta de cuidados à saúde da mulher indígena}

Na formação dos AIS um dos grandes desafios foi o desenvolvimento de estratégias pedagógicas que os qualificassem para desenvolver cuidados de saúde da mulher indígena, sem ignorar a existência de produções culturais que limitam a intervenção masculina no espaço reprodutivo feminino, restringindo, por exemplo, a abordagem de suas consanguíneas e das esposas de outros homens de seu grupo de parentesco.

Outra dificuldade decorreu da baixa inserção de mulheres no trabalho de agente de saúde no DSEl Alto Rio Negro. Na época de realização do curso, de um total de quase duzentos AIS que atuavam nas aldeias indígenas do Alto Rio Negro, somente vinte eram do sexo feminino, dadas as preferências das famílias em indicar jovens do sexo masculino para o desempenho de tarefas advindas do mundo não indígena.

Além disso, à época, a equipe multidisciplinar de saúde não dispunha, neste DSEl, de orientações específicas que direcionassem o trabalho do agente de saúde no campo da saúde da mulher indígena, o que gerou mais um desafio ao desenvolvimento da temática no processo formador.

Nesse cenário, priorizou-se um perfil de habilidades e competências, a serem desenvolvidas pelos estudantes, alinhadas às tarefas rotineiramente executadas pelos outros membros das equipes multiprofissionais na realização de ações dirigidas à saúde 
da mulher, nas aldeias. Em outras palavras, trabalhou-se para produzir um perfil de atuação do AIS que fosse compatível com as especificidades culturais do meio em que atua e com as rotinas adotadas no DSEI, ainda que com certas adaptações.

O planejamento das atividades formativas contou com a revisão de relatórios e outros documentos institucionais que ofertassem à equipe de coordenação do curso uma visão global das atividades em saúde da mulher desenvolvidas no DSEl onde realizou-se o curso. O levantamento preliminar permitiu perceber que no Alto Rio Negro também se reproduziam práticas comuns em unidades de atenção básica para usuárias não indígenas, direcionando os cuidados à saúde da mulher à oferta de frações de atenção programática como vacinação, atenção ao pré-natal e prevenção de câncer do colo do útero.

Na busca de uma abordagem mais ampla e integral, as atividades pedagógicas iniciaram pela problematização de condições de vida da mulher indígena, enfatizando a vida e trabalho cotidiano e algumas dimensões culturalmente específicas como ritos femininos de passagem e o associativismo feminino indígena. A exploração desses temas visava estimular a reflexão sobre a relação entre os modos de vida e os níveis de saúde das mulheres. Em razão da ausência de informações locais sobre o tema, optou-se pelo uso de vídeos que tratassem do assunto em outras realidades indígenas, conduzindo, na sequência, a uma discussão coletiva voltada para o contexto rio-negrino.

O primeiro vídeo que versava sobre a vida comunal de grupos étnicos no parque do Xingu despertou reações de identificação com as cenas do cotidiano xinguano, como exemplificado nas avaliações feitas pelos estudantes: "[eles] fazem roça e pescam como nós"; "[lá] as mulheres ralam mandioca como acontece aqui"; "[no Xingu] as pessoas também fazem artesanato"; "[Eles] fazem benzimentos para proteger a saúde". Também foi possível identificar reações de estranheza ante os modos de vida dos índios do Xingu: "um homem tinha três mulheres e muitos filhos"; "as famílias fazem ritual para menina-moça e nós não fazemos mais"; "eles moram em malocas como nossos antepassados". Tais manifestações conduziram uma discussão sobre a importância de preservar modos tradicionais de vida como estratégias de manutenção da saúde das mulheres.

Os vídeos seguintes traziam um conjunto de depoimentos sobre associações de mulheres indígenas, inserindo a temática da luta pela terra entre grupos que não têm a garantia das áreas demarcadas. Os documentários também problematizavam a violência de gênero, pois um deles trazia depoimentos de mulheres indígenas que falavam de dificuldades domésticas decorrentes da atitude agressiva de seus parceiros. O teor dos vídeos favoreceu a politização da discussão e permitiu ampliar a abordagem da saúde da mulher para além das dimensões biológicas e das ações dos serviços de 
saúde e redirecioná-la para o plano dos determinantes sociais. No caso indígena, os vídeos tanto remetem às contradições de gênero instituídas pelos acordos matrimoniais definidos pelas regras de parentesco e de afinidade quanto ao contexto das relações interétnicas que tendem a exacerbar conflitos eventualmente existentes no interior das sociedades indígenas.

A apresentação e discussão dos vídeos propiciou a introdução dos conceitos de "condições de vida" e de "modos de vida", além de evidenciar nexos entre os perfis de saúde e de doença das mulheres indígenas e os modos como as pessoas vivem (costumes, rotinas familiares etc.). Também favoreceu o reconhecimento de situações de vulnerabilidade enfrentadas pelas mulheres, em contraponto à oferta de ações pelo sistema de saúde que, não raro, são pouco congruentes com as necessidades de saúde percebidas pelas famílias indígenas.

A temática seguinte trabalhada foi o perfil epidemiológico da mulher e criança indígenas. Ainda que a unidade pedagógica tratasse da saúde da mulher, os docentes optaram por discutir também o perfil epidemiológico das crianças menores de 5 anos, em virtude do reconhecimento da íntima interação entre um tema e o outro. A estratégia adotada foi a apresentação de um conjunto de slides em que foram sistematizados os resultados do I Inquérito Nacional de Saúde e Nutrição dos Povos Indígenas no Brasil (Coimbra et al., 2013), com ênfase nas informações relativas às mulheres e crianças menores de 5 anos.

A apresentação dialogada foi conduzida em ritmo pausado, preocupando-se em esclarecer a terminologia epidemiológica inerente ao tema, em responder as dúvidas dos estudantes sobre os conteúdos e em correlacionar os dados apresentados com situações concretas da vida nas aldeias. Ressalte-se que o principal objetivo dessa atividade não era ensinar terminologia e lógica epidemiológica, mas favorecer a compreensão de que existe uma frequência elevada de agravos à saúde entre as mulheres indígenas. Também buscava demonstrar a ocorrência de doenças e mortes que poderiam ser evitadas com a melhoria das condições de vida nas aldeias indígenas e o aprimoramento da qualidade e da frequência com que o sistema de saúde oferece cuidados às populações aldeadas. A última dimensão enfatizada nessa fase do processo formador foi a demonstração das desigualdades nos indicadores de saúde de mulheres e crianças indígenas, bastante desfavoráveis em comparação àqueles encontrados entre não indígenas.

A discussão sobre o perfil epidemiológico das mulheres indígenas propiciou o mote para introdução da temática definição de prioridades em saúde da mulher. A ideia nesse caso foi demonstrar para os estudantes que o perfil epidemiológico deve guiar a programação das ações de saúde, as quais devem ser dimensionadas para atender 
aos principais problemas de saúde de uma população. No caso específico de saúde da mulher, os indicadores de gravidez de risco, morte materna e das principais doenças que ocorrem entre as mulheres deveriam guiar as atividades a serem priorizadas no sistema de saúde. Nessa fase, os estudantes também desenvolveram uma atividade de ensino pela pesquisa, levantando as necessidades de saúde da população feminina da aldeia sede do curso. A tabulação e a análise dos dados mostraram uma preponderância de queixas relacionadas ao sistema musculoesquelético e de agravos relacionados às concepções tradicionais de doença. Com base em tais resultados, instituiu-se um debate sobre as razões e consequências da baixa congruência entre as necessidades de saúde percebidas pelas pessoas e o perfil de ações priorizadas pela rede de serviços oficiais de saúde.

O passo seguinte foi a apresentação e discussão da Política Nacional de Saúde da Mulher, entendida como um conjunto de prioridades e diretrizes a serem adotadas em todo território nacional, cuja base de orientação volta-se para o ataque aos principais problemas de saúde que ocorrem na população de interesse. A finalização dessa fase permitiu demonstrar para os estudantes as correlações necessárias entre o perfil epidemiológico da população feminina e as atividades a serem priorizadas na política nacional de saúde da mulher, o que inclui a rede de unidades de saúde do DSEI. Também se discutiu a ausência de menções às condições de saúde da mulher indígena na política nacional, evidenciando o caráter etnocêntrico das grandes iniciativas governamentais, que se apresentam pouco sensíveis às necessidades e peculiaridades das minorias étnicas no país.

As atividades continuaram com a discussão das fases da vida da mulher, abordando de modo equilibrado tanto as interpretações culturais sobre o assunto quanto as concepções biomédicas que orientam a produção de cuidados de acordo com as faixas etárias da população feminina. A busca de entendimento sobre as fases da vida da mulher indígena de acordo com o conhecimento tradicional gerou a necessidade de desenvolver estratégias de ensino pela pesquisa, pois os estudantes mostraram pouco domínio sobre o tema.

Em razão desse pouco domínio sobre o tema, os alunos foram encarregados de levantar informações com os conhecedores indígenas de ambos os gêneros, com o objetivo de compreender como se produz a feminilidade; como esta interatua com o regime de parentesco; e como é interpretada a vida reprodutiva nas culturas dos estudantes. As ações de ensino pela pesquisa também tiveram como missão aprender sobre doenças tradicionais específicas das mulheres e o significado desses eventos para os sujeitos. Tais iniciativas visavam adentrar ao mundo indígena sem se prender às categorias biomédicas que se limitam a estipular demarcadores biológicos e a prescrever as ações de saúde com base neles. 
Pelo contrário, o que se buscava era remeter a abordagem da saúde da mulher às teorias e práticas nativas de produção de corpos e de gênero, que são centrais no ordenamento dos sistemas indígenas de cura e cuidados (Langdon, 2005).

O resultado desses levantamentos mostrou que, do ponto de vista indígena, os problemas de saúde e cuidados preconizados com a gravidez não se limitam ao período da gestação, mas devem se iniciar no nascimento da menina e continuar ao longo da vida. De acordo com essa lógica, a promoção da saúde reprodutiva deve se iniciar com um conjunto de ritos pós-natais que congregam pai, mãe e a recém-nascida. Os procedimentos rituais devem ser retomados em outros momentos-chave da vida da mulher, como a menarca, os ciclos menstruais e após cada parto.

As pesquisas dos estudantes evidenciam importante contradição: é intenso o ritmo de cuidados biomédicos instituídos durante a gestação pelo sistema oficial de saúde, mas eles se restringem aos meses da gravidez e puerpério imediato. Em contraste, as noções nativas sobre a saúde da mulher, cuja preservação pressupõe um conjunto de cuidados que deve perpassar longitudinalmente a vida, não se limitam à fase gestacional. No debate que permeou a análise dos procedimentos de ensino pela pesquisa, os estudantes entenderam que seria relevante partilhar seus achados com os profissionais não indígenas que atuam no DSEl, explicitando a diferença de perspectivas entre o sistema indígena de cura e cuidados e as rotinas adotadas pelo DSEl, de modo que os outros membros da Emsi pudessem apreender sobre a diversidade de sentidos dos determinantes sociais e culturais da saúde e dos agravos à reprodução humana.

A atenção pré-natal foi um dos tópicos ao qual se dedicou extensa carga horária do curso, tanto por ser uma atividade regularmente realizada no DSEI quanto pela suspeita de que haja elevados níveis de morte materna indígena, ainda que não se pudesse comprová-los, já que o DSEl não disponibilizou informações a esse respeito.

Nesse âmbito, temas como detecção precoce da gravidez e evolução da gestação foram tratados. O início do pré-natal no primeiro trimestre da gestação é um dos procedimentos apontados como relevantes para uma oferta adequada da atenção prénatal. Entretanto, a literatura recorrentemente revela a dificuldade de captação precoce das gestantes pelo sistema de saúde, em todo território nacional. Não encontramos publicações que analisassem a ocorrência de problema em terras indígenas, porém os estudantes presentes no curso foram unânimes em apontar sua dificuldade de fazer busca ativa de grávidas em início de gestação, porque, sendo eles do sexo masculino, perguntas desse teor seriam consideradas infrações à etiqueta das relações entre gêneros.

Explicaram-se de forma bastante detalhada as razões pelas quais o início precoce do pré-natal é uma medida importante para a prevenção das doenças gestacionais e da 
morte materna. Discutiram-se as implicações culturais do reconhecimento público da gravidez e construíram-se algumas estratégias de educação e comunicação em saúde apoiadas na distinção de gênero, que é bem marcada nas sociedades rio-negrinas.

Dentre os produtos da discussão, aponta-se a recomendação de que os agentes de saúde devem sensibilizar os esposos que vivem na comunidade, motivando-os a convencer suas esposas a buscar a atenção ao pré-natal logo que suspeitem estar grávidas. Trata-se de uma medida que visa contornar - sem ferir - as interdições que tradicionalmente envolvem as interações entre homens e mulheres, direcionando o esforço dos AIS para seus homólogos de gênero. Os estudantes também produziram material educativo em suas línguas nativas dirigido ao uso no espaço comunitário, com explicações sobre a importância do início precoce do pré-natal, na tentativa de estimular a busca desses cuidados na gestação.

Tema correlato foi o ensino do cálculo da idade gestacional (IG) em semanas e trimestres. Tal estratégia se fez necessária por percebermos que os estudantes tinham dificuldade de entender a terminologia utilizada para efetuar o cálculo da idade gestacional e que poucos conseguiam realizar os cálculos necessários para obtê-la. Esse raciocínio matemático mostrou-se de difícil compreensão pelos estudantes, pouco familiarizados com a evolução em semanas, em vez de meses, da gravidez. Também foram orientados sobre o cálculo da data da última menstruação (DUM) e data provável do parto (DPP).

Porém, mais importante do que efetuar com perfeição esses cálculos - principalmente porque são informações rotineiramente disponíveis no cartão/caderneta da gestante - foi o entendimento de seu significado para a identificação precoce da gravidez e seu uso potencial para monitorar atentamente a gestação, em particular no terceiro trimestre. Como atividade sequencial elaborou-se um quadro de sinais e sintomas que expressam complicações na gravidez, visando auxiliar os agentes indígenas a reconhecer intercorrências que geram risco à mãe e à criança e subsidiar os encaminhamentos de tais situações aos outros membros da equipe de saúde.

As atividades pedagógicas avançaram para uma discussão detalhada, mediada por dramatizações, sobre o conjunto de atividades rotineiramente desenvolvidas pela equipe multiprofissional do DSEI na realização do pré-natal nas aldeias. As cenas reconstituídas pelas dramatizações possibilitaram a percepção de que, além de conduzirem as gestantes às consultas e de eventualmente atuarem como tradutor, não havia tarefas específicas a serem realizadas pelos AIS, seja no pré-natal, seja em outros aspectos da saúde da mulher. Com base nessa constatação, os professores aprofundaram os esforços para sistematizar, juntamente com os estudantes, um conjunto de atribuições específicas a serem desenvolvidas pelos AIS no polo feminino de suas comunidades. 
Nesse âmbito, duas estratégias se mostraram prioritárias: a exploração minuciosa dos registros contidos no cartão da gestante e o manejo do Sisvan. Investiu-se em muitas horas de aulas para promover o entendimento de todos os campos do cartão da gestante, a fim de que os estudantes aprendessem a revisá-lo, compreendessem o significado das informações ali contidas e, sobretudo, entendessem que as lacunas representam cuidados não efetivados, seja por falha no atendimento ou no registro, seja por estarem programadas para futura realização.

A exploração da temática do cartão da gestante desenvolveu-se inicialmente por meio da projeção, em sala de aula, de um cartão de gestante não preenchido. Na sequência, cada campo do cartão foi apresentado e teve seu conteúdo explicado e devidamente correlacionado com as ações de rotina desenvolvidas no pré-natal. O passo seguinte foi estimular os estudantes a buscar cartões de gestantes da comunidade, fazer a revisão de cartões já preenchidos e analisar o registro de cuidados anteriormente prestados e/ ou o agendamento feito. O processo incentivou a formulação de um juízo crítico dos estudantes sobre o desempenho das ações de pré-natal no DSEI, permitindo distinguir um pré-natal com adequada realização das ações daquele em que os procedimentos requeridos estavam em atraso ou não tinham sido realizados.

A análise de registro da vacinação também é um tópico de importância, promovendo não apenas a discussão sobre as doses aplicadas e as faltantes, mas também informação sistemática sobre o esquema vacinal na gravidez e realizando estudos de caso que permitiram aos estudantes avaliar a situação vacinal de gestantes, dimensionar necessidades de agendamento futuro, reconhecer esquemas vacinais em dia e/ou completos e identificar grávidas que necessitam completar sua vacinação.

O aprendizado das ações do Sisvan seguiu molde similar ao adotado no curso para o tema de saúde da criança, compreendendo a tomada de medidas antropométricas, cálculo de índice de massa corporal (IMC), reconhecimento e classificação de risco nutricional, reconhecimento de situações de risco, manejo e registro de informações no formulário do Sisvan e orientação alimentar. Dessa forma, os estudantes obtiveram um manejo adequado das normas técnicas e procedimentos de vigilância nutricional requeridos pelo Sisvan para o acompanhamento das gestantes e, simultaneamente, oportunizaram a revisão e consolidação do aprendizado sobre a vigilância alimentar e nutricional feito anteriormente no estudo de saúde da criança.

O trabalho pedagógico dirigido aos cuidados pré-natais - tanto do ponto de vista da tradição quanto do ponto de vista da saúde pública - buscou subsidiar os AIS para entender o conjunto de cuidados preconizados para o acompanhamento da gestação e monitorar o seu desenvolvimento, sensibilizando as gestantes e suas famílias para 
buscarem, precoce e regularmente as consultas por ocasião da presença da equipe nas aldeias e para valorizar os cuidados tradicionais direcionados à promoção da saúde da mulher. Além disso, qualificar os agentes de saúde para monitoramento das ações de atenção pré-natal favorece sua interação com os outros membros da equipe de saúde, apontando necessidades de encaminhamento das grávidas para o atendimento por ocasião da presença da equipe na aldeia, além de gerar alertas e pedidos tempestivos de remoção em casos de intercorrências clínicas que ameacem a gestante e a criança.

Fiel à ideia de propor no pré-natal um conjunto de ações específicas para os AIS, mas integrado às atividades dos outros membros da equipe, o curso desenvolveu um fluxograma no qual as suas responsabilidades e a dos demais estavam dispostas de forma articulada (Figura 14).

\section{Figura 14 - Fluxograma de Organização das Consultas de Pré-Natal, com definição de atribuições do AIS}

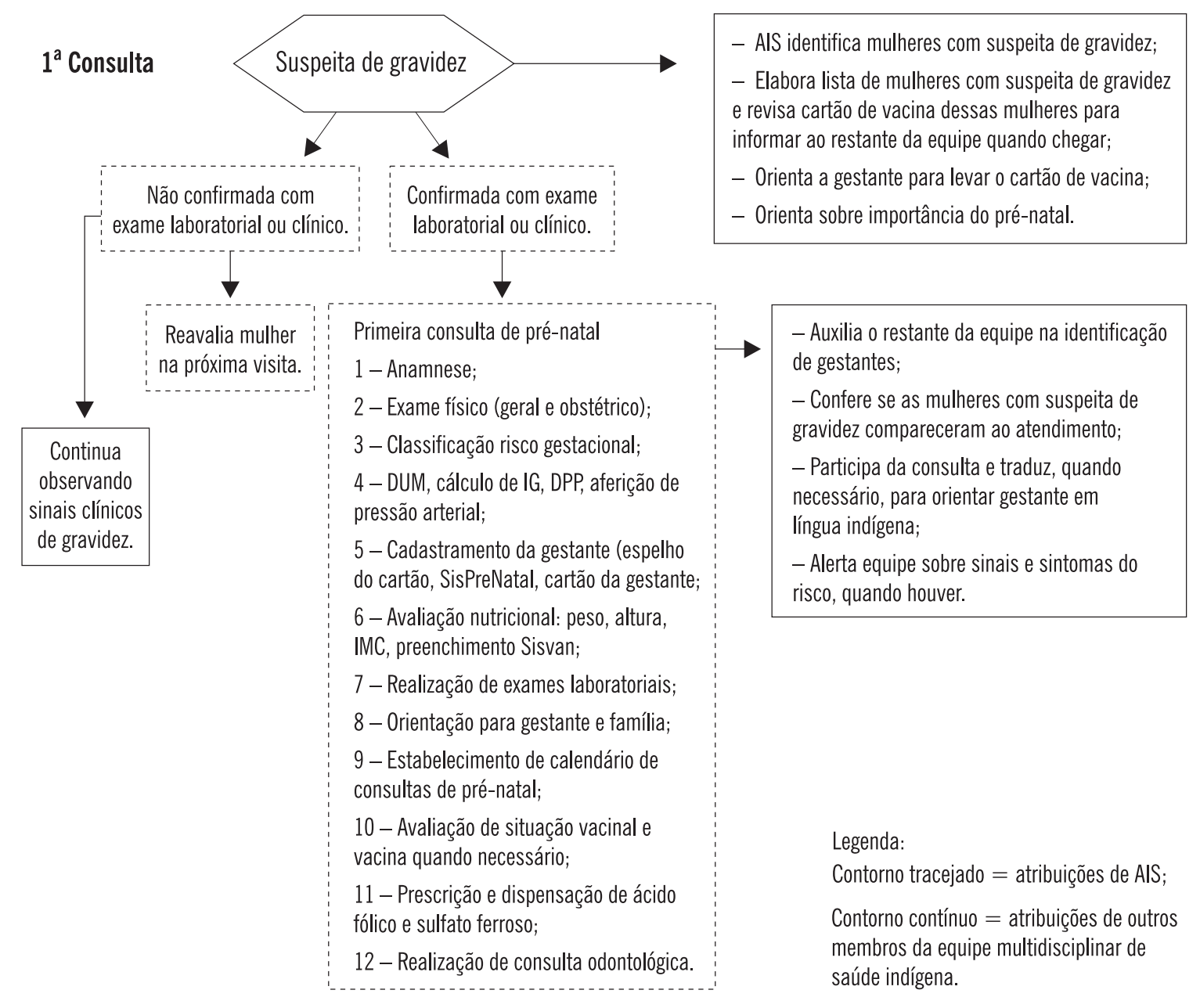




\section{Figura 14 - Fluxograma de Organização das Consultas de Pré-Natal, com definição de atribuições do AIS (continuação)}

Pré-natal - Consultas subsequentes

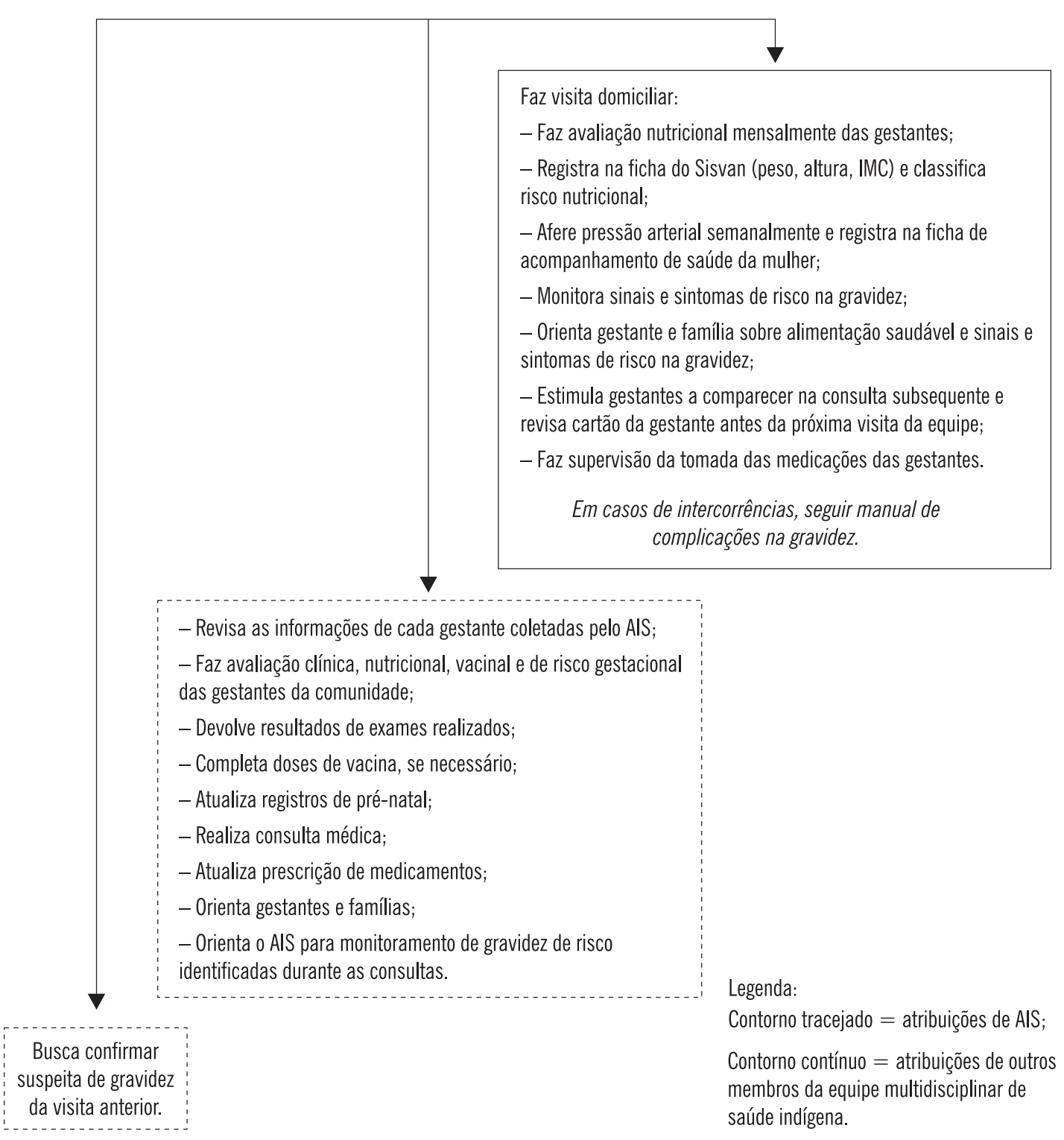

Acervo CTACIS (2009-2015).

Na região do Alto Rio Negro, o AIS tem uma importante participação na tomada de decisão para solicitar a remoção de pacientes para atenção de segundo nível na sede municipal. Na busca de qualificar a tomada de decisão para pedido de remoção de gestantes em situações de risco, ofertou-se um panorama simples, mas objetivo, dos sinais e sintomas das doenças que ocorrem na gravidez, do abortamento e outras situações de risco clínico característico desse período. Também se apresentou o conceito de gravidez de risco, visando auxiliar os estudantes a reconhecer casos de complicação 
na gravidez, a fim de que pudessem emitir ou solicitar avaliações e remoções de urgência para proteção da gestante e da criança. Subsidiariamente elaborou-se e disponibilizouse para todos os estudantes um glossário de termos mais comuns utilizados em saúde da mulher, visando facilitar o domínio vocabular desse campo de atuação.

Para além da temática da gravidez e suas complicações, mas com a mesma finalidade de reconhecer e prevenir complicações, discutiram-se as manifestações fisiológicas do parto normal e as intercorrências clínicas que caracterizam as complicações no parto. Também se problematizaram as ideias e práticas tradicionais relativas ao parto, sendo instituído um denso debate sobre a hospitalização do parto normal. Essa é uma prática recentemente instituída pelos profissionais do DSEI, que vem crescendo, pois, a remoção de gestantes indígenas para o parto hospitalar na cidade tem sido frequente. $O$ debate estimulou os estudantes a refletirem sobre os prós e contras de cada opção, sem a preocupação de optar por nenhuma delas, mas conduzindo-os a compreenderem as consequências potenciais de cada uma das escolhas.

Uma das pré-condições para o reconhecimento de sinais de risco na gestação e no parto foi o aprendizado da avaliação dos sinais vitais (pulso, temperatura, pressão arterial e ritmo respiratório), ao lado do reconhecimento de manifestações físicas que expressam condições de risco à vida. Esses conteúdos foram desenvolvidos essencialmente por meio de atividades práticas em que o domínio de tais técnicas foi exercitado à exaustão, durante essa fase do curso e nos seus momentos finais em que foram trabalhadas ações de suporte à vida.

Outros agravos à saúde da mulher também foram trabalhados, ainda que de modo mais breve, com a finalidade de aprimorar a capacidade de reconhecer tais situações e melhor subsidiar os encaminhamentos para outros membros da equipe. Discutiram-se temas como câncer de mama e de colo do útero, sangramento vaginal, corrimentos e agravos musculoesqueléticos decorrentes do trabalho feminino. Não se pretendeu que o AIS prescrevesse ou manejasse clinicamente tais casos, nem atendessem às mulheres nas intercorrências gestacionais. O objetivo era responder à necessidade de os estudantes compreenderem tais eventos, para que aprendessem a reconhecer os sinais de alerta e pudessem acionar, sem delongas, os outros membros da equipe em busca de orientações ou de remoção da pessoa doente em caso de sinais de gravidade e comprometimento do suporte à vida. Um conteúdo relevante, que foi trabalhado em detalhe, visou ao apoio às ações de controle do câncer de colo do útero (PCCU) e ao planejamento familiar. No caso do PCCU, o esforço docente direcionou-se ao entendimento do que é o câncer de colo do útero e quais são as finalidades do exame. A prospecção sobre o tema no início do curso evidenciou que os estudantes tinham ideias vagas e confusas sobre o 
que seria câncer, onde ocorreria e como se manifestaria, bem como sobre as razões para realização do exame de rastreamento. A condição masculina da maioria dos agentes de saúde dificultava o acesso à observação in loco de tais situações, gerando interpretações imprecisas que, em consequência, impossibilitavam a realização de ações educativas e motivacionais para adesão ao PCCU.

$\mathrm{Na}$ busca de suprir tal lacuna de conhecimento preparou-se uma apresentação clara e objetiva sobre a anatomia e fisiologia do aparelho reprodutor feminino, bem como da fisiopatogenia e manifestações clínicas do câncer de colo do útero. Também se apresentou um vídeo demonstrando a técnica de coleta de material biológico para a realização do exame de colpocitologia oncótica. A pretensão pedagógica não objetivava envolver os agentes de saúde na coleta de material para realizar o exame colpocitológico, mas sim que entendessem as propostas de prevenção desse agravo, possibilitando o desenvolvimento de atividades educativas com membros da comunidade, capazes de ampliar a adesão aos procedimentos preventivos.

Ao final dessa temática, solicitou-se que os estudantes preparassem material educativo sobre o câncer de colo de útero e suas medidas de prevenção, visando a futura apresentação na aldeia. Após elaborados, textos e cartazes - produzidos originalmente em suas línguas indígenas - foram traduzidos para o português para que se aferisse a precisão do conteúdo e se corrigissem eventuais problemas de tradução e/ou interpretação do assunto. Solicitou-se que o material fosse produzido em língua nativa porque havia a necessidade de fixar o aprendizado dessa temática, que é bastante complexa, a fim de levar o estudante a refletir com profundidade sobre o assunto, e porque era necessário dispor de um conteúdo sobre o câncer de colo do útero enunciado em língua falada na comunidade, para facilitar o acesso à informação pelas mulheres indígenas que têm menor domínio da língua portuguesa na região do Alto Rio Negro. O caminho inverso exigiria grande esforço para traduzir do português noções que não existem no universo cognitivo dos indígenas; esse procedimento implicaria a reelaboração de conceitos técnicos sobre o câncer de colo do útero, a fim de expressá-los em língua nativa.

A exploração da temática do planejamento familiar surgiu como necessidade identificada no próprio curso, pois inicialmente não se planejava adentrar nesse assunto. Entretanto, depoimentos dos estudantes deixaram clara a existência de muitas mulheres fazendo uso de anticoncepcionais em regime de automedicação, utilizando comprimidos e injetáveis comprados nas farmácias da cidade, sem prescrição médica e sem orientação adequada. Nessas circunstâncias, optamos por explorar a temática mediante o reconhecimento dos principais tipos de contraceptivos disponíveis no SUS e nas farmácias da sede municipal. Assim, os estudantes puderam entender os modos de 
utilizar tais medicamentos, qualificando-se para monitorar o uso feito pelas mulheres da comunidade e manter os outros membros da equipe informados sobre datas de vencimento, de renovação de prescrição e queixas femininas sobre efeitos colaterais, além de alertar as famílias sobre eventuais efeitos adversos e riscos da automedicação.

A ampla variedade de temas que o cuidado à saúde da mulher assumiu durante o processo formador apontou a necessidade de os AIS disporem de um formulário inexistente no sistema de registros do DSEI - no qual pudessem registrar e sistematizar as atividades realizadas com as mulheres indígenas. O produto dessa iniciativa está disposto na Figura 15.

Figura 15 - Formulário de acompanhamento da saúde da mulher indígena

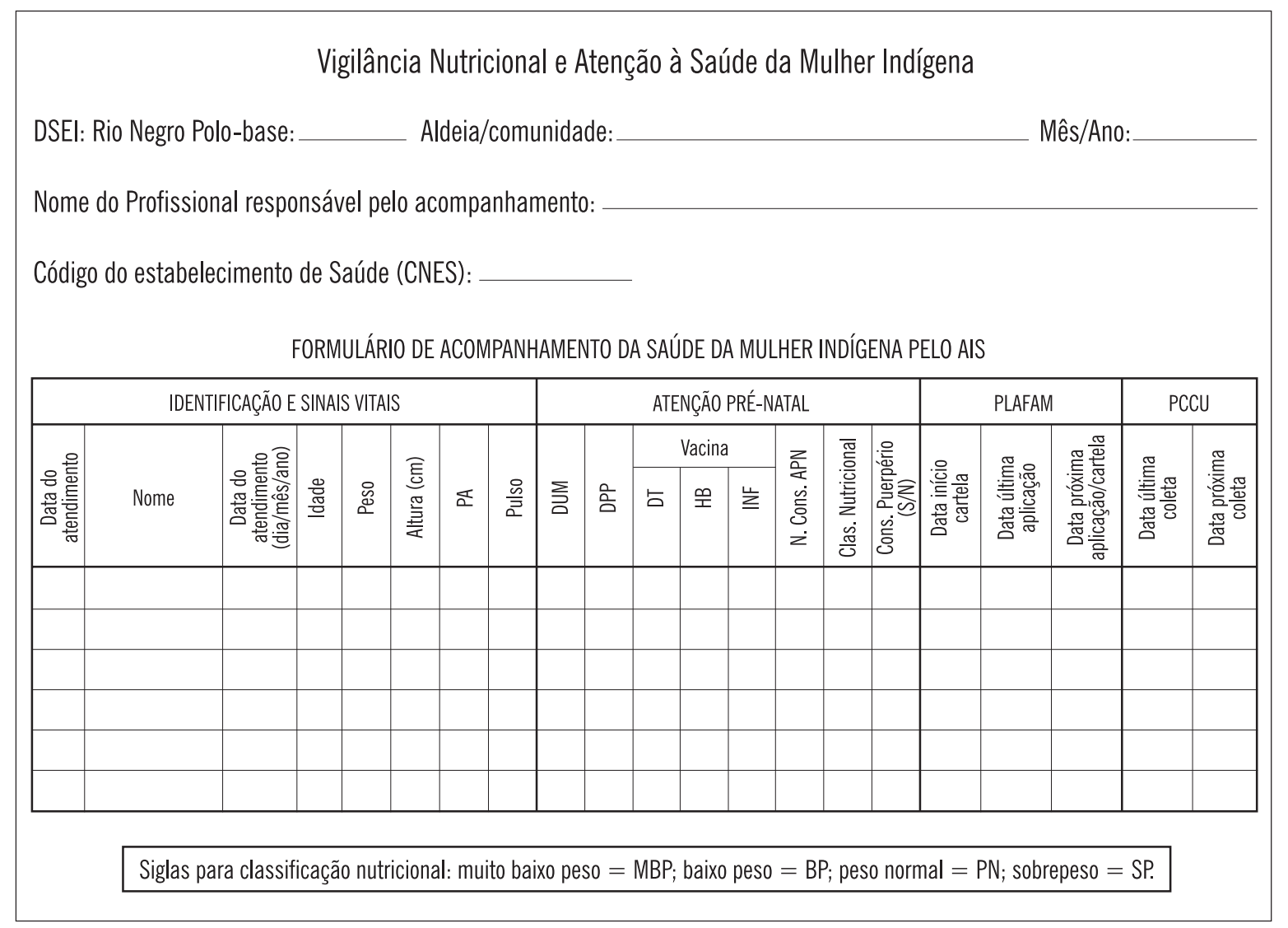


Figura 15 - Formulário de acompanhamento da saúde da mulher indígena (continuação)

\begin{tabular}{|c|c|c|}
\hline \multicolumn{3}{|c|}{ FORMULÁRIO DE ACOMPANHAMENTO DA SAÚDE DA MULHER INDÍGENA PELO AIS (VERSO) } \\
\hline Nome da mulher & Data da visita & Observações sobre situações observadas na visita \\
\hline & & \\
\hline & & \\
\hline & & \\
\hline & & \\
\hline & & \\
\hline & & \\
\hline & & \\
\hline
\end{tabular}

Acervo CTACIS (2009-20I5).

A última atividade relativa ao tema saúde da mulher indígena foi a criação de um roteiro detalhado de visita domiciliar em saúde da mulher, no qual se sistematizaram todas as atividades que o AIS pode desenvolver cotidianamente na comunidade para realizar as ações de monitoramento aprendidas no curso e colocar em prática as habilidades e competências desenvolvidas.

\section{Novas atribuições do AIS em saúde da mulher}

O desenvolvimento das atividades pedagógicas direcionadas à saúde da mulher indígena produziu um amplo e variado conjunto de informações e atribuições dos AIS, criando condições para que eles superassem a situação anterior, em que não desempenhavam papel relevante nesse campo de atuação. Além disso, seu conhecimento sobre as relações sociofamiliares tradicionais era pouco valorizado e não era levado em consideração nas atividades educativas e de promoção à saúde sexual e reprodutiva. O amplo leque de ações dirigidas às mulheres indígenas deixou clara a complexidade desse campo de ação na rede de APS, na qual a saúde da mulher ganha um espaço destacado.

Ferreira (2013) reflete sobre as contradições e dificuldades para se instituir uma política de saúde da mulher indígena e recomenda que tais abordagens a reconheçam como sujeitos relacionais, incluídos em estruturas sociais ordenadas segundo grupos de parentesco, em que são instituídos modos específicos de feminilidade que não devem ser desconsiderados pelas políticas públicas, em particular pela política de 
saúde indígena. Tais considerações ofertaram importante balizamento das atividades formativas, buscando equilibrar o domínio de ações técnicas resolutivas com uma abordagem humanizada e culturalmente sensível do cuidado ofertado às mulheres indígenas. Porém, o processo formador não descurou a abordagem do contexto em que as mulheres indígenas vivem, se constituem como sujeitos e reproduzem suas famílias perseguindo a especificidade cultural que a política de saúde indígena anuncia, mas que tem dificuldade de convertê-la em práxis. 


\section{Aprendizados gerados pela experiência e potencialidades de adaptação para outros contextos}

A realização do CTACIS na região do Alto Rio Negro propiciou um rico aprendizado docente-discente no âmbito do próprio curso, e com potencial para aplicação em outros contextos no Sasi e até mesmo na rede de APS voltada para o atendimento de não indígenas.

Nessa trajetória, o primeiro ponto a ser destacado foi o intenso e contínuo envolvimento do movimento indígena, representado naquela região pela FOIRN, cujo protagonismo político se exerceu não apenas na demanda que desencadeou a iniciativa, mas também ao longo de todo o processo formador, em que a federação teve papel crucial de apoio ao curso nos momentos em que enfrentou sérias ameaças de interrupção. A constância das lideranças na defesa do curso contrabalançou a instabilidade gerada pelas recorrentes mudanças de profissionais e dirigentes do DSEl e da própria Sesai. A cada mudança de pessoal, a coordenação do CTACIS precisava promover rodadas de reuniões para explicar ao(s) novo(s) integrante(s) a origem e as finalidades do curso, os modos de funcionamento e outros dados que sensibilizassem os recém-chegados para a importância da iniciativa.

Muito importantes também foram a paciente atuação de lideranças indígenas como docentes do curso, recuperando a história não escrita das lutas étnico-políticas travadas pelo movimento indígena rio-negrino nos últimos trinta anos, bem como a atuação dos especialistas em medicinas tradicionais que, repetidas vezes, trabalharam com os AIS. Entendemos que uma relação sólida com lideranças de movimentos sociais é condição estratégica para uma bem-sucedida replicação da experiência.

Frequentemente se fala sobre a dificuldade de realizar, articuladamente, a elevação da escolaridade formal e a profissionalização em nível médio. Nossa experiência nesse âmbito foi positiva, seja por parte dos gestores da educação, em particular dos encarregados da educação escolar indígena que demonstraram forte interesse na iniciativa, seja por parte 
dos estudantes que deram o melhor de si para lidar com múltiplas demandas e atender aos requisitos no curso. Consideramos que a aproximação do campo da saúde indígena com o da educação indígena foi fundamental para o exercício da sensibilidade cultural no processo formador, devendo ser estimulada em iniciativas similares.

A construção curricular do curso também deve ser objeto de reflexão nesta avaliação final. A eleição de temáticas como modelo de atenção orientado para vigilância em saúde e organização/reorganização do processo de trabalho em saúde para a mesma finalidade resultou numa abordagem que explorou a articulação teórico-prática entre vigilância e serviços de saúde. Este enfoque aportou inovações na maneira de desenvolver conteúdos curriculares que contribuíssem para o reordenamento do processo de trabalho e para a superação do modelo biomédico, orientado para a demanda espontânea. Dentre os conteúdos que orientaram a reorganização do trabalho do AIS destacam-se o entendimento das condições de vida e a detecção de necessidades de saúde no território. Com essa perspectiva mais ampla, foi possível refletir sobre modos de vida, aí incluída a concepção indígena de bem viver, e explorar as interrelações com a sustentabilidade ambiental. Trata-se de uma questão crucial para as famílias rio-negrinas cujas principais fontes de subsistência dependem da preservação de seus territórios e da vitalidade dos conhecimentos tradicionais, pois estes permeiam a gestão das relações com a natureza e as técnicas de extração de recursos para a subsistência, bem como minimizam os danos (materiais e simbólicos) decorrentes da predação humana.

O cruzamento entre o conhecimento dos modos indígenas específicos de viver em território e as ações de vigilância a serem desenvolvidas pelo AIS talvez seja o aspecto de mais difícil adaptação dos conteúdos do curso para outras realidades. Para desenvolvêla adequadamente, seria necessário ancorar o processo formador em conhecimento antropológico prévio sobre os grupos étnicos participantes no curso. Entretanto, no Brasil, não se dispõe de acervo próprio para todas as etnias atendidas pelo Sasi. Tais obstáculos podem ser minimizados mediante a seleção de docentes e supervisores com ampla experiência pedagógica, vivência na relação ensino-serviço e sensibilidade às demandas e necessidades de saúde dos grupos envolvidos. Importante também é o conhecimento sobre as características do exercício do poder político intra e interétnico nos locais de realização dos cursos.

Porém, mesmo na ausência de antropólogos com conhecimento das culturas nativas envolvidas na iniciativa, a opção da estratégia ensino pela pesquisa pode suprir, em grande medida, a necessária produção de informações desenvolvidas pelos próprios estudantes. É essencial que pelo menos um membro da equipe tenha experiência com pesquisa aplicada ao ensino, e que seja capaz de sistematizar as informações obtidas por essa via e de convertê-las em conteúdos significativos de aprendizado. 
No curso ministrado no Alto Rio Negro, destacam-se, como exemplo de abordagens apoiadas no ensino pela pesquisa, os conteúdos curriculares de saúde da mulher e da criança, cujo desenvolvimento se apoiou fortemente na ideia nativa de fases ou ciclos de vida. Sugere-se, nesses casos, vigilância atenta aos riscos e armadilhas advindos de categorias biomédicas, tão arraigadas em nosso senso comum que seu caráter etnocêntrico costuma passar desapercebido. Como exemplos, podemos citar, entre outras, noções problematizadas ao longo dos capítulos anteriores, tais como, faixa etária, infância, corporalidade. O levantamento do entendimento nativo dessas categorias pode ser feito através do ensino pela pesquisa, prática pedagógica com potencial para guiar a proposta de organização de um cuidado não limitado pelo molde biomédico.

Essa estratégia propiciou a organização de um amplo acervo de materiais que versam sobre os territórios, modos de vida e saberes indígenas que foram retomados e reaproveitados em diversos momentos do curso. A análise minuciosa desse acervo ainda está por ser feita, devendo ser objeto de estudos futuros.

O corpo docente fez um grande esforço para construir, com os estudantes, um conjunto de atribuições para os AIS, orientadas pelo modelo de vigilância em saúde e trabalhadas em cada eixo temático do curso. O leitor talvez se ressinta da falta de um delineamento equivalente para os outros profissionais da equipe. Cabe esclarecer, portanto, que a apresentação de um conjunto de atribuições em alguns capítulos, e em particular no detalhado roteiro orientador da realização da visita domiciliar, não expressa a ideia de isolamento na atuação do AIS. Pelo contrário, a iniciativa buscou ofertar um guia de ações específicas a serem desenvolvidas por um membro da equipe cujo perfil de atribuições permanece insuficientemente delineado, não apenas no Sasi, mas no SUS como um todo. Além disso, o foco do curso se dirigia aos AIS, não cabendo extrapolar a proposta de redesenho de atribuições para outros profissionais.

Ainda assim, a harmonização entre as atribuições de diversos profissionais que atuam nas Emsis (AIS e demais membros) se fez visível em diversos momentos. Está exemplificada no fluxograma de organização das consultas de pré-natal, em que as tarefas e a interatuação de todos os membros da Emsis estão claramente apresentadas, mas sem abrir mão de demonstrar atividades específicas a serem desenvolvidas pelo AIS (conferir capítulo 6).

Os coordenadores do curso, em decorrência da sua experiência prévia, já tinham clareza de que as potencialidades do trabalho do AIS eram subaproveitadas no trabalho cotidiano das equipes do DSEI. Esse foi um dos fatos que gerou a demanda do curso pelas lideranças indígenas. A percepção de que aos AIS só eram delegadas tarefas subalternas e braçais guiou a luta da FOIRN pela elevação da escolaridade e formação profissional 
em nível médio, bem como pela reivindicação de um espaço próprio de atuação para o membro indígena da Emsi, na busca de propor um conjunto de atividades especificas do trabalho do AIS, sem perder de vista o lugar que esse ocupa nas linhas de cuidado instituídas pelo DSEl e as características de sua inserção na comunidade.

Outro aspecto a ser considerado é que na Amazônia, diferentemente de outras realidades, os AIS representam a primeira - e por vezes a única - linha de frente na oferta de cuidados de APS. Além disso, a carência de rede de serviços os obriga ao manejo de situações de emergência, que, ao ocorrerem em lugares remotos, obrigam os agentes a assumir um papel estratégico na identificação de sinais de riscos que ameaçam a vida e a tomar decisões sobre encaminhar, ou não, um doente para um serviço de saúde localizado fora da aldeia. Em que pese esse papel imposto pelas características do rural amazônico, poucos eram os AIS preparados para identificar esses sintomas e efetuar a tomada de decisão necessária para cada caso.

Não se trata de atribuir aos AIS o papel de médico socorrista, mas de reconhecer que as carências assistenciais vigentes na região compelem os profissionais a realizar ações que extrapolam o nível de cuidados típicos de APS. Conhecedores dessa realidade e das difíceis condições de acesso às aldeias indígenas, entendemos que o curso deveria incluir um determinado número de horas para capacitar os AIS a identificar situações que ameaçam a vida e para auxiliá-los na adoção de parâmetros para a tomada de decisões.

O envolvimento dos profissionais das Emsis foi sempre um pressuposto orientador do processo formativo, seja pelo desejo de garantir-Ihes a participação, seja pelo propósito de sensibilizá-los para a importância do modelo assistencial calcado na vigilância em saúde. Tínhamos a certeza, também, de que os AIS não poderiam desenvolver as novas tarefas a contento se não contassem com o apoio e a orientação dos outros profissionais, em particular dos enfermeiros. Tal propósito mostrou-se um desafio que poucas vezes foi satisfatoriamente superado ao longo do curso, dada a dificuldade de garantir a participação continuada dos profissionais do DSEI nas atividades de cada polo formador. Entre as razões para essa descontinuidade, constataram-se a desmotivação dos profissionais com o trabalho, o desinteresse por atividades formativas e, principalmente, o descumprimento do calendário de viagens de atendimento em área indígena e a elevada rotatividade dos profissionais e gestores do DSEI. Os problemas relativos à falta de motivação eram facilmente solucionados após alguns dias de frequência ao curso; ali o entusiasmo de estudantes e professores contagiava a todos. Os demais, inerentes à organização do trabalho no DSEI, se converteram em obstáculos a serem contornados a cada fase do processo formativo, e, sobre eles, não tínhamos qualquer governabilidade. 
Também tivemos pouco sucesso no enfrentamento da resistência de muitos profissionais em rever suas rotinas de trabalho para adicionar atividades como reconhecimento do território, educação em saúde e programação da demanda, entre outras. A capacitação dos AIS para essas tarefas passou a gerar demandas similares para os outros profissionais; alguns responderam positivamente, ao passo que outros persistiram mantendo a prioridade dada ao atendimento por demanda espontânea. Paralelamente, observamos limitada aceitação da ampliação do escopo das atividades dos AIS por parte dos profissionais que atuavam no DSEI, mas não participavam do curso. Aqueles que colaboraram com a iniciativa aprofundaram vínculos com os AIS e ampliaram sua compreensão sobre a relevância desse novo perfil de atuação, reconhecendo sua potencialidade em contribuir no aprimoramento do trabalho da equipe como um todo. Porém, os que nunca haviam participado mantiveram atitudes reticentes e defensivas, sendo perceptível, em alguns casos, a enunciação de juízos depreciativos sobre os AIS e o entendimento de que suas novas atribuições representavam ameaças ao trabalho rotineiro instituído. Em consequência, houve relatos de que alguns integrantes da equipe multiprofissional desestimulavam, ou até mesmo impediam, a execução das novas tarefas dos AIS, pactuadas no curso.

Tais relatos reafirmam o caráter político das linhas guia do projeto pedagógico do curso, gerando contradições com o modelo biomédico de atuação, predominante no DSEl. Trata-se de nível de discordância mais profundo que a mera recusa ao processo de qualificação do trabalho dos AIS que revela apego a rotinas pouco compromissadas com as características da APS e dificultam a conversão em direção a um modelo assistencial pautado pelas necessidades de saúde no território. Tal problema não é específico do Sasi. Trata-se, pelo contrário, de um entrave no processo de gestão da APS que perpassa boa parte da rede assistencial.

Reafirma-se, assim, a importância do envolvimento dos outros membros da equipe no processo formador, visto que as atitudes negativas provieram justamente dos que não aceitaram participar das atividades do curso. É plausível supor que situações similares sejam encontradas em outros locais e contextos, uma vez que as assimetrias e hierarquias entre categorias profissionais não se limitam aos DSEls ou à rede de APS encontrando sua gênese na própria estrutura de classes da sociedade.

A adoção de pedagogias ativas consorciadas às múltiplas estratégias de ensinoaprendizado priorizou as atividades práticas e a atuação docente dos sábios indígenas, mostrando-se um caminho produtivo que efetivou, na prática, uma das ambições interculturais do curso: a de equilibrar de modo harmônico o aporte de saberes científicos e indígenas no processo formador. Além de propiciar uma via de escape do monopólio 
exercido pelo conhecimento biomédico nos cursos anteriores ofertados ao AIS, tal escolha também expressa o compromisso político de trazer para primeiro plano, e como parte integrante das atribuições do AIS, a interlocução não apenas com especialistas tradicionais de cura, mas também com as pessoas comuns das aldeias, reconhecidas como protagonistas e detentoras de conhecimento e de meios de produzir saúde. O uso intensivo das dramatizações foi bastante importante para identificar as expectativas dos AIS acerca do seu papel na equipe e na comunidade. Essa prática também produziu relatos tão vívidos e sistemáticos quanto os obtidos por etnografias e possibilitou descortinar um panorama da atuação cotidiana dos profissionais não indígenas, marcada, não raro, por juízos de valor carregados de etnocentrismo.

A produção textual e gráfica de materiais educativos não só cumpriu finalidades inerentes à educação em saúde dirigida à comunidade, mas também operou como estratégia de revisão de conteúdos e de avaliação formativa do aprendizado, conduzindo os estudantes à produção de novos significados aos materiais educativos, à medida que os traduziam do português para as línguas indígenas e vice-versa. Muito mais que uma transposição de termos de uma língua para outra, trata-se de uma reconstrução, pautada no primado do local, de saberes, conceitos, significados e estratégias de ação que visam a adequá-los às condições e modos de vida nos cenários de atuação dos AIS.

Um avanço derivado da tradução de elementos de sentido de uma cultura para outra é o reconhecimento da importância de incluir diferentes pontos de vista na priorização das necessidades e problemas de saúde. Em que pese a importância da informação epidemiológica para orientar essa tomada de decisão em saúde, as reuniões comunitárias deixaram bem claro que as necessidades sentidas podem ser muito distintas das que são consideradas como prioritárias pelas políticas públicas e pela atuação das equipes de saúde. A valorização do diálogo com a população atendida permitiu evidenciar que as mulheres indígenas tinham como demanda principal algum tipo de solução para o crescente acúmulo de lixo nas aldeias e para suas dores de ordem musculoesqueléticas decorrentes das duras condições do trabalho na roça. Para a primeira reivindicação, o DSEl não dispunha de qualquer proposta, encaminhamento ou diálogo com as comunidades para equacionar o problema gerado pela ampliação do consumo de produtos industrializados. A segunda demanda - muito relevante para combater a desnutrição, já que é o trabalho feminino que provê a maior parte do alimento consumido na família - sequer era reconhecida pelos profissionais como problema de saúde digno de constar nas metas e prioridades de ação nos planos distritais. Essas dores não eram tratadas como um problema de saúde do trabalhador rural, e sua abordagem se limitava à prescrição de sintomáticos, induzindo ao uso abusivo de anti-inflamatórios. 
A exploração minuciosa dos instrumentos de registro e de acompanhamento utilizados pela equipe de saúde possibilitou compreender que não se tratavam de meros entraves burocráticos. Foi possível avaliar a importância desses instrumentos para ordenar as atribuições e rotinas de atuação dos profissionais da saúde e para entender a lógica organizativa do cuidado, bem como a gravidade dos problemas acarretados pelo mau uso deles. Cabe destacar a reação - entre surpresa e indignação - dos estudantes ao perceberem inúmeras falhas de registro e de realização de ações do pré-natal, depois que aprenderam a revisar os cartões/cadernetas de suas esposas e irmãs gestantes. De modo similar, a apresentação detalhada e objetiva da técnica de coleta de exame de Papanicolau mostrou que, por vezes, colocar a explicação biomédica em primeiro plano é a melhor via para entender as razões pelas quais as mulheres devem realizar esse exame. O vídeo apresentado sobre o tema deu concretude a um assunto nebuloso para os AIS, uma vez que sua condição masculina dificultava-lhes imaginar de que forma o exame preventivo do câncer de colo de útero era realizado, o que tornava pouco convincente sua tentativa de motivar as mulheres a aderirem ao procedimento.

Antes de finalizarmos, faz-se necessário problematizar as tensões surgidas em torno da elevação da escolaridade dos AIS como consequência do curso. Essa foi sem dúvida a principal fonte de insatisfação de gestores que atuavam na Sesai, à época em que foi realizado. Do início ao fim da iniciativa, o posicionamento de gestores do Sasi evidenciou o interesse pelo caráter inovador e culturalmente sensível da proposta, desde que consistisse em mera atualização. Entretanto, se opunham ao reconhecimento dos AIS como técnicos de nível médio, pois alegavam falta de provimento desse cargo no seu quadro de alocação de pessoal terceirizado.

Tal argumento é usado também por outros gestores do SUS contrários ao reconhecimento da elevação da escolaridade de seus contratados, pois priorizam a necessidade de reduzir gastos com pessoal. Esse é um impasse que pode obstaculizar a replicação da experiência em outros DSEls ou em secretarias municipais de Saúde, dada a conhecida restrição dos gestores em onerar as folhas de pagamento com o reenquadramento dos AIS como profissionais de nível médio.

Apesar do posicionamento negativo dos dirigentes sobre o tema, optamos por persistir e efetivar a elevação da escolaridade até a conclusão do nível médio com formação profissionalizante. As razões para fazê-lo foram essencialmente políticas: em primeiro lugar, atendíamos a uma reivindicação das lideranças indígenas, comprometidas com a melhoria das condições de vida dos seus povos e sabedoras que a escolarização é uma das vias preferenciais para alcançar essa meta. Também tínhamos clareza de que a ambição do projeto em potencializar a implantação das ações de vigilância no 
escopo de atividades dos AIS demandaria um processo pedagógico longo e complexo que exigiria proficiência em campos de saberes mais aprofundados que não poderiam ser obtidos apenas nas primeiras séries escolares. Na ausência de elevação concomitante da escolaridade, o maior aproveitamento do curso só poderia ocorrer entre os estudantes que já tivessem concluído ensino fundamental e médio, ou seja, a minoria. Estávamos bem conscientes do valor que os povos do Alto Rio Negro atribuem à educação e do quanto ela representava para a autoestima dos AIS. Somente os que testemunharam a emoção dos nossos estudantes na cerimônia de formatura puderam compreender quão significativo foi, para todos nós, ter logrado finalizar a experiência com sucesso.

Também tínhamos clareza de queo campo da saúdeéum cenário marcado pela hierarquia de profissões e que a baixa escolaridade dos AIS era uma das fontes de desvalorização profissional aos olhos dos outros integrantes das equipes multidisciplinares. A luta por respeitabilidade profissional não se restringe a elevar a escolaridade, mas certamente passa por ela. Consideramos mais do que justo que o profissional que permanece nas comunidades ao longo de todo o ano receba remuneração condizente com sua atuação no Sasi. Também consideramos que os dirigentes comprometidos com a melhoria da qualidade da atenção devem reconhecer o saldo positivo que a qualificação dessa força de trabalho pode representar na efetividade das ações de APS sob sua responsabilidade.

Por razões como essas persistimos em levar a experiência até o desfecho originalmente programado. Temos, porém, ciência das implicações subjacentes a essa questão. Por isso, organizamos a implementação dos conteúdos do CTACIS de modo a permitir que estes possam ser recortados e executados em frações menores, compatíveis com atividades de capacitação com escopo mais curto e complexidade menor do que a iniciativa levada a cabo no Alto Rio Negro. Ou seja, consideramos factível a oferta de cursos curtos voltados para o controle de agravos específicos de doenças vetoriais, monitoramento de agravos imunopreveníveis, vigilância alimentar e nutricional e outros temas que possam ser extraídos da matriz curricular e efetivados mediante o uso de estratégias pedagógicas e materiais instrucionais elaborados no curso rionegrino. Sem dúvida, tais iniciativas podem ampliar a aplicabilidade da proposta do CTACIS com bastante chance de sucesso, ainda que fiquem enfraquecidos os aspectos políticos e socioambientais contidos na proposta original.

Entretanto, cada conjuntura política tem sua própria dinâmica. No caso do estado do Amazonas, a ensinagem freiriana produzida no CTACIS sustenta o projeto QualificaSUS, dedicado à capacitação de cinco mil ACS nos 62 municípios do estado, o qual está em fase de implantação pelo Instituto Leônidas $\varepsilon$ Maria Deane, unidade da Fiocruz em Manaus. Mais pragmático e menos ambicioso que o CTACIS, o projeto QualificaSUS 
adapta temas, conteúdos e materiais educativos concebidos no curso do Alto Rio Negro, com o objetivo de ofertar cem turmas de cursos de curta duração para ACS não indígenas atuantes em áreas rurais do Amazonas. O programa está começando e não dispõe ainda de produtos que permitam avaliação de processo ou de resultados. Porém, a escolha do CTACIS como eixo guia para a implantação de um novo processo de ensino-aprendizagem já é um indicador de replicabilidade do curso rio-negrino a outros contextos e realidades.

Neste livro somente se relatou uma parte da experiência formativa no Alto Rio Negro. Há ainda um amplo material inédito que versa sobre outros temas não incluídos aqui por limitação de espaço e que deverá ser objeto de futuras publicações dos autores deste livro.

As atribuições do AIS desenvolvidas no curso CTACIS foram sistematizadas de acordo com cada eixo formador e estão dispostas no Quadro I 2.

\section{Quadro 12 - Atribuições do AIS em APS nos DSEls construído no CTACIS}

\begin{tabular}{|c|c|}
\hline Atribuiç̧ões do AIS & Atividades sugeridas \\
\hline \multirow{6}{*}{$\begin{array}{l}\text { Organização } \\
\text { do processo de } \\
\text { trabalho segundo } \\
\text { princípios da APS }\end{array}$} & $\begin{array}{l}\text { Delimitar seu território de atuação e reconhecer a população sob sua } \\
\text { responsabilidade. }\end{array}$ \\
\hline & $\begin{array}{l}\text { Identificar os grupos e territórios mais vulneráveis e suas distintas } \\
\text { necessidades de saúde. }\end{array}$ \\
\hline & $\begin{array}{l}\text { Planejar e executar visitas domiciliares para conhecer as condições de vida, } \\
\text { a situação de saúde e as necessidades de atenção das famílias sob seus } \\
\text { cuidados. }\end{array}$ \\
\hline & $\begin{array}{l}\text { Desenvolver ações de promoção da saúde, prevenção das doenças e ofertar } \\
\text { cuidados, segundo seu perfil de competências. }\end{array}$ \\
\hline & $\begin{array}{l}\text { Estimular a participação das famílias no planejamento, execução e avaliação } \\
\text { das ações de saúde. }\end{array}$ \\
\hline & $\begin{array}{l}\text { Promover o acompanhamento contínuo e longitudinal de pessoas e famílias } \\
\text { sob cuidado, buscando meios para garantir o acesso aos demais níveis de } \\
\text { atenção. }\end{array}$ \\
\hline \multirow{3}{*}{$\begin{array}{l}\text { Elaboração de } \\
\text { diagnóstico } \\
\text { comunitário para } \\
\text { subsidiar o trabalho } \\
\text { da Emsi }\end{array}$} & $\begin{array}{l}\text { Elaborar mapas comunitários com localização de domicílios, de recursos } \\
\text { comunitários para produção da subsistência, lazer e outras atividades } \\
\text { comunais, além da identificação de locais de risco. }\end{array}$ \\
\hline & $\begin{array}{l}\text { Fazer levantamento populacional da comunidade e elaborar pirâmide } \\
\text { demográfica. }\end{array}$ \\
\hline & $\begin{array}{l}\text { Aplicar questionário para levantamento da situação socioeconômica das } \\
\text { famílias da comunidade. }\end{array}$ \\
\hline
\end{tabular}




\section{Quadro 12 - Atribuições do AIS em APS nos DSEls construído no CTACIS (continuação)}

\begin{tabular}{|c|c|}
\hline Atribuições do AIS & Atividades sugeridas \\
\hline \multirow{4}{*}{$\begin{array}{l}\text { Elaboração de } \\
\text { diagnóstico } \\
\text { comunitário para } \\
\text { subsidiar o trabalho } \\
\text { da Emsi }\end{array}$} & $\begin{array}{l}\text { Realizar levantamento e sistematização de dados sobre problemas e } \\
\text { necessidades de saúde das famílias. }\end{array}$ \\
\hline & $\begin{array}{l}\text { Fazer levantamento e registro sobre doenças e cuidados tradicionais } \\
\text { adotados na comunidade. }\end{array}$ \\
\hline & $\begin{array}{l}\text { Fazer levantamento e registro sobre a história da comunidade e relações de } \\
\text { contato interétnico, identificando suas repercussões nos modos de vida das } \\
\text { famílias, quando pertinente. }\end{array}$ \\
\hline & $\begin{array}{l}\text { Identificar os especialistas tradicionais que vivem no território indígena em } \\
\text { sua área de abrangência. }\end{array}$ \\
\hline \multirow{5}{*}{$\begin{array}{l}\text { Realizar o } \\
\text { planejamento das } \\
\text { atividades do AIS } \\
\text { em conjunto com } \\
\text { as comunidades e } \\
\text { a Emsi }\end{array}$} & $\begin{array}{l}\text { Realizar regularmente o diagnóstico comunitário no intuito de analisar a } \\
\text { dinâmica do perfil populacional e a ocorrência dos principais problemas de } \\
\text { saúde. }\end{array}$ \\
\hline & $\begin{array}{l}\text { Discutir com lideranças e comunidades os resultados e obter o diagnóstico } \\
\text { comunitário para estabelecer prioridades para a atuação do AIS. }\end{array}$ \\
\hline & $\begin{array}{l}\text { Organizar o plano de trabalho do AIS na comunidade, definindo problemas } \\
\text { prioritários, ações programadas, estratégias de alcance de resultados e } \\
\text { prazos para realização. }\end{array}$ \\
\hline & $\begin{array}{l}\text { Apresentar para lideranças e o restante da Emsi o planejamento do trabalho } \\
\text { do AIS e seu desenvolvimento. }\end{array}$ \\
\hline & $\begin{array}{l}\text { Avaliar junto com a comunidade e o restante da Emsi o desenvolvimento do } \\
\text { plano de ação dos AIS. }\end{array}$ \\
\hline \multirow{6}{*}{ Controle social } & $\begin{array}{l}\text { Conhecer a atuação da organização indígena da sua região e participar de } \\
\text { suas atividades desenvolvendo propostas voltadas para a melhoria da saúde. }\end{array}$ \\
\hline & $\begin{array}{l}\text { Participar das reuniões e atividades comunitárias, dos conselhos locais de } \\
\text { saúde e de associações de base local, apresentando dados sobre a situação } \\
\text { de saúde de sua área de abrangência e propondo ações de desenvolvimento } \\
\text { sustentável, melhoria da alimentação e do saneamento das comunidades. }\end{array}$ \\
\hline & $\begin{array}{l}\text { Acompanhar reuniões e outras atividades dos Conselhos Distritais de Saúde } \\
\text { e Conferências Nacionais de Saúde Indígena. }\end{array}$ \\
\hline & $\begin{array}{l}\text { Realizar, na comunidade, debates sobre as políticas de saúde e de saúde } \\
\text { indígena e atividades de controle social na sua região. }\end{array}$ \\
\hline & $\begin{array}{l}\text { Esclarecer os moradores sobre a política de saúde indígena, planejamento } \\
\text { anual e ações programadas para os serviços de saúde na área de abrangência } \\
\text { do DSEI. }\end{array}$ \\
\hline & $\begin{array}{l}\text { Conhecer as políticas sociais inclusivas existentes no seu território, visando } \\
\text { à divulgação e ao fortalecimento. }\end{array}$ \\
\hline
\end{tabular}




\section{Quadro 12 - Atribuições do AIS em APS nos DSEls construído no CTACIS (continuação)}

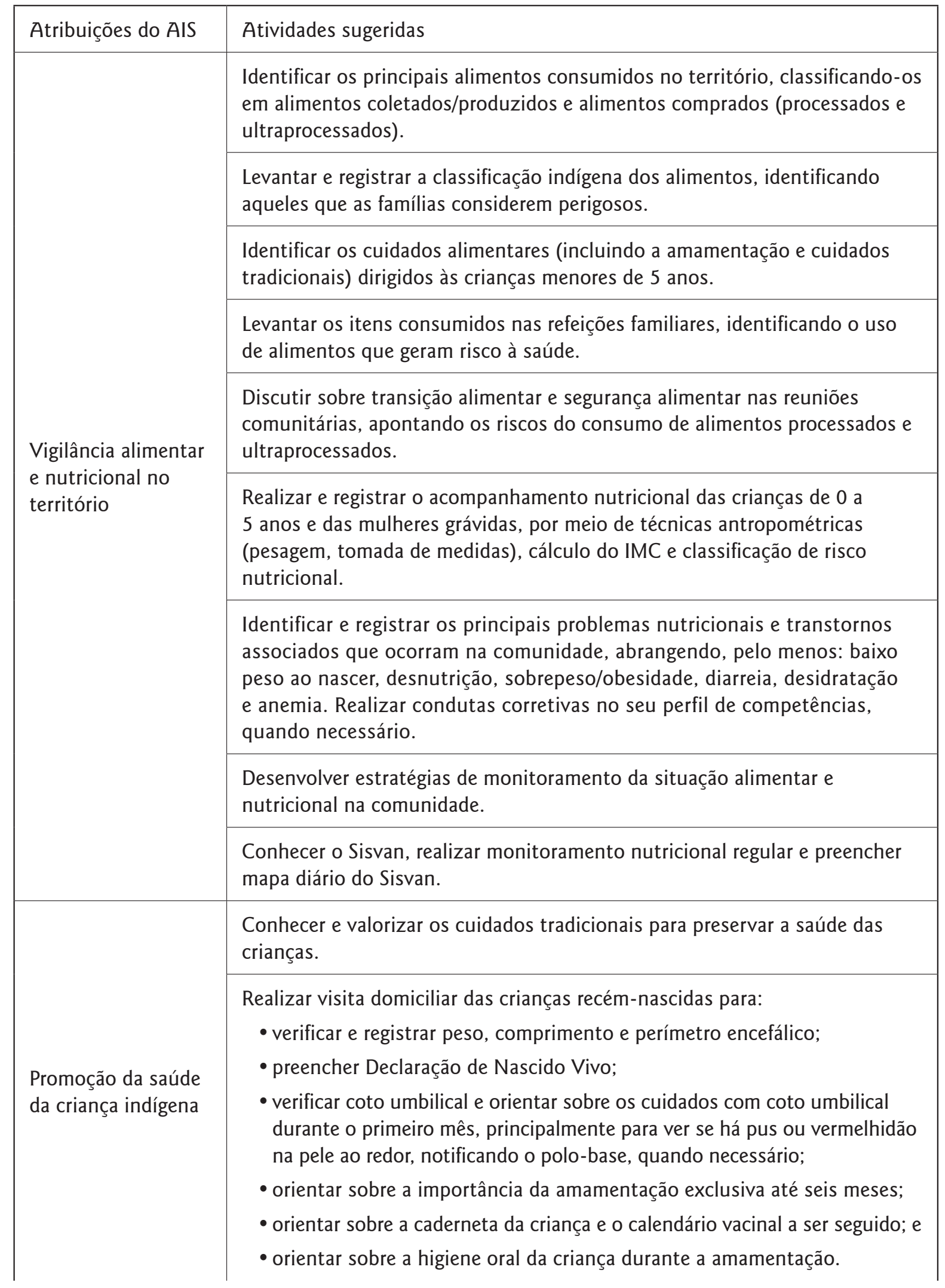




\section{Quadro 12 - Atribuições do AIS em APS nos DSEls construído no CTACIS (continuação)}

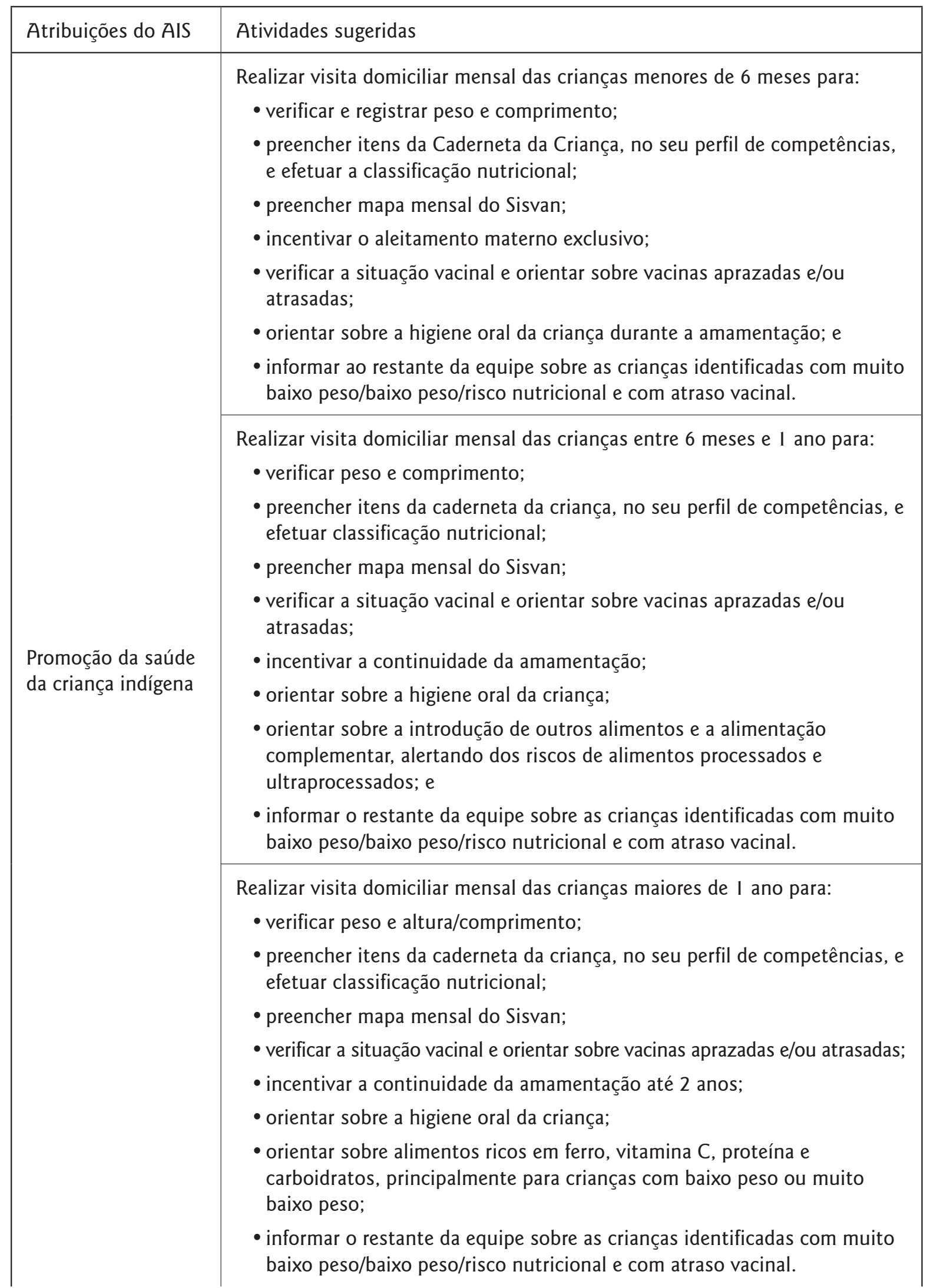




\section{Quadro 12 - Atribuições do AIS em APS nos DSEls construído no CTACIS (continuação)}

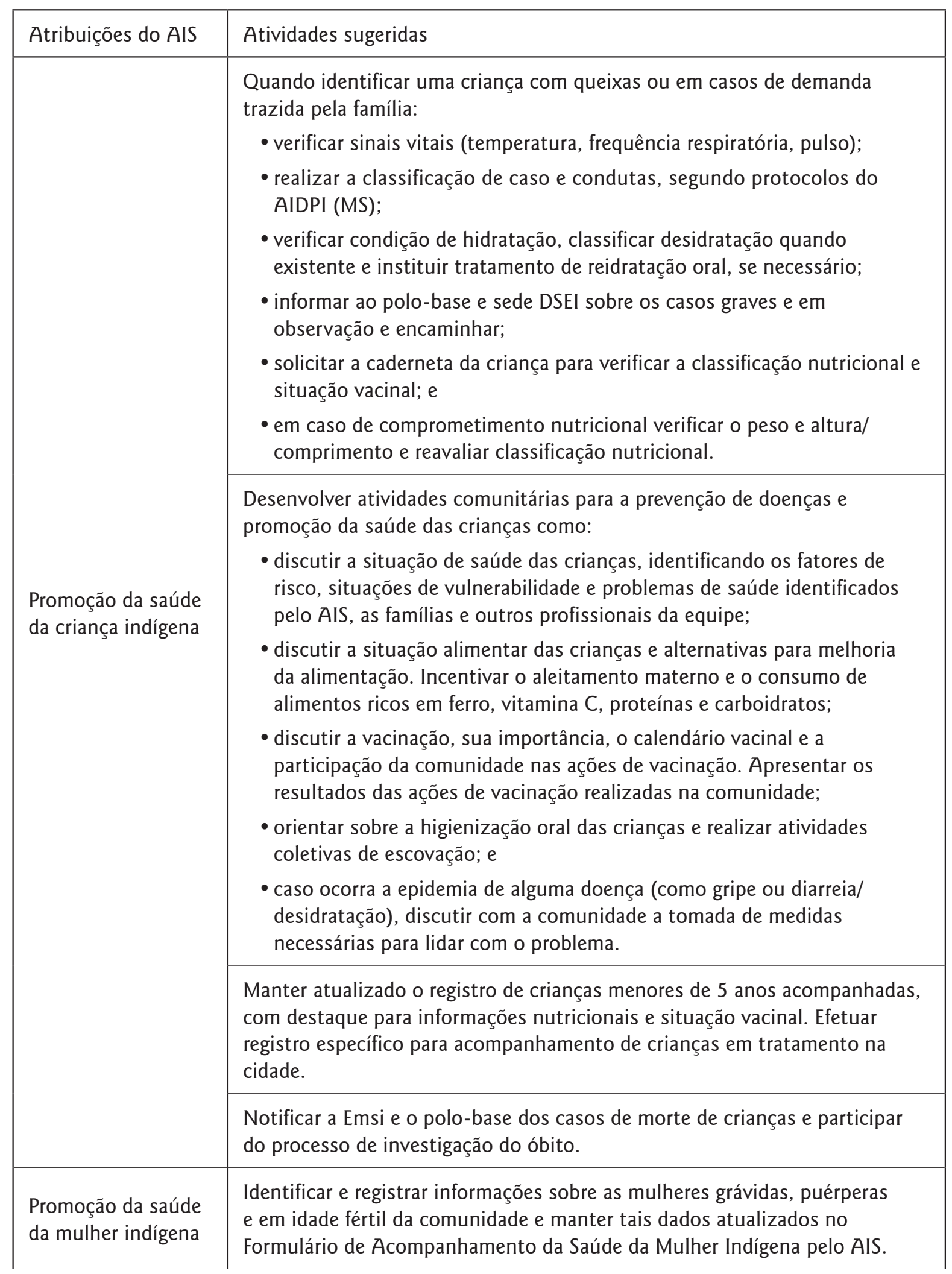




\section{Quadro 12 - Atribuições do AIS em APS nos DSEls construído no CTACIS (continuação)}

\begin{tabular}{|c|c|}
\hline Atribuições do AIS & Atividades sugeridas \\
\hline \multirow[t]{4}{*}{$\begin{array}{l}\text { Promoção da saúde } \\
\text { da mulher indígena }\end{array}$} & $\begin{array}{l}\text { Identificar as mulheres grávidas e realizar visita domiciliar mensal para: } \\
\text { - pesar, medir altura, aferir PA, pulso e anotar esses resultados; } \\
\text { - verificar a existência de queixas sugestivas de doença e/ou intercorrência } \\
\text { na gravidez ou no puerpério; se houver queixas comunicar ao polo-base; } \\
\text { - revisar caderneta da gestante e/ou cartão de vacina, com prioridade para } \\
\text { os seguintes itens: DUM, DPP, número de consultas de APN, número de } \\
\text { consultas de puerpério (se for o caso) e doses de vacina já aplicadas; } \\
\text { - avaliar a situação vacinal da gestante e, caso existente, informar as } \\
\text { equipes sobre necessidades de vacinação; } \\
\text { - realizar a avaliação nutricional da gestante, preenchimento dos } \\
\text { formulários do Sisvan e efetuar orientação alimentar; } \\
\text { - verificar o uso de suplemento de sulfato ferroso e orientar sobre uso do } \\
\text { medicamento e sobre alimentos ricos em ferro; } \\
\text { - realizar o registro mensais das informações de acompanhamento da } \\
\text { gestante no Formulário de Acompanhamento da Saúde da Mulher } \\
\text { Indígena pelo AIS, mês a mês; } \\
\text { - conversar e orientar sobre cuidados tradicionais com a mulher na } \\
\text { gravidez; } \\
\text { - se a gestante ou puérpera tiver queixas de sangramento, corrimento, dor } \\
\text { ou outros sintomas deve informar o restante da Emsi. }\end{array}$ \\
\hline & $\begin{array}{l}\text { Discutir na comunidade sobre a importância do fortalecimento dos cuidados } \\
\text { tradicionais no parto e orientar sobre as indicações específicas de parto } \\
\text { hospitalar. }\end{array}$ \\
\hline & $\begin{array}{l}\text { Caso a comunidade considere adequado, conversar com a mulher e/ } \\
\text { ou esposo sobre o uso de métodos contraceptivos para orientações, } \\
\text { encaminhamento à equipe e acompanhamento do uso de anticoncepcionais } \\
\text { prescritos. }\end{array}$ \\
\hline & $\begin{array}{l}\text { Realizar o acompanhamento do preventivo do colo uterino (PCCU) das } \\
\text { mulheres na faixa etária entre } 25 \text { a } 65 \text { anos, por meio de: } \\
\text { - atividades educativas para as mulheres e familiares sobre realização do } \\
\text { exame do PCCU e sua importância; } \\
\text { - acompanhamento da frequência da realização do PCCU, mantendo um } \\
\text { registro atualizado das datas de coleta, aprazamento e das mulheres com } \\
\text { exames em atraso. Informar os outros membros da equipe sobre exames } \\
\text { em atraso; e } \\
\text { - identificação e encaminhamento, para os outros membros da equipe, das } \\
\text { mulheres com necessidade de realizar exames do PCCU. }\end{array}$ \\
\hline
\end{tabular}




\section{Quadro 12 - Atribuições do AIS em APS nos DSEls construído no CTACIS (continuação)}

\begin{tabular}{|c|c|}
\hline Atribuições do AIS & Atividades sugeridas \\
\hline \multirow{6}{*}{$\begin{array}{l}\text { Promoção da saúde } \\
\text { da mulher indígena }\end{array}$} & $\begin{array}{l}\text { Identificar mulheres com queixas de corrimento, de dor ou outros sintomas } \\
\text { de doenças ginecológicas, para encaminhamento ao polo-base. }\end{array}$ \\
\hline & $\begin{array}{l}\text { Desenvolver atividades comunitárias de educação em saúde sobre: } \\
\text { • importância e rotinas de pré-natal e dos cuidados com as mulheres } \\
\text { grávidas; }\end{array}$ \\
\hline & $\begin{array}{l}\text { • importância da higienização oral das mulheres e, em particular, das } \\
\text { grávidas; }\end{array}$ \\
\hline & $\begin{array}{l}\text { - discutir a situação nutricional encontrada na população de grávidas da } \\
\text { comunidade; e }\end{array}$ \\
\hline & • orientar sobre alimentação saudável. \\
\hline & $\begin{array}{l}\text { Apresentar seus registros e resultados do acompanhamento das mulheres } \\
\text { grávidas aos outros membros da Emsi. }\end{array}$ \\
\hline \multirow{10}{*}{$\begin{array}{l}\text { Prevenção e controle } \\
\text { de portadores } \\
\text { de hipertensão e } \\
\text { diabetes* }\end{array}$} & $\begin{array}{l}\text { Realizar atividades educativas individuais e coletivas sobre doenças crônicas } \\
\text { como diabetes tipos I e Il e hipertensão, seus principais fatores de risco e } \\
\text { medidas de prevenção. }\end{array}$ \\
\hline & $\begin{array}{l}\text { Realizar e/ou participar de atividades individuais e coletivas para } \\
\text { rastreamento de hipertensão e diabetes tipo II em maiores de } 18 \text { anos, com } \\
\text { aferição de PA, dosagem de glicemia e classificação nutricional segundo IMC. }\end{array}$ \\
\hline & $\begin{array}{l}\text { Realizar visita domiciliar para acompanhamento das pessoas com medidas } \\
\text { alteradas de glicemia e hipertensão para que sejam orientadas sobre } \\
\text { fatores de risco, tratamento não medicamentoso e encaminhamento para } \\
\text { confirmação diagnóstica, quando necessário; }\end{array}$ \\
\hline & $\begin{array}{l}\text { As pessoas com diagnóstico confirmado de diabetes e hipertensão devem } \\
\text { ser acompanhadas para: }\end{array}$ \\
\hline & $\begin{array}{l}\text { - medir PA semanalmente e manter registro atualizado dos resultados para } \\
\text { apresentá-los aos outros membros da EMSI; }\end{array}$ \\
\hline & $\begin{array}{l}\text { - verificar periodicamente a glicemia capilar e manter registro atualizado } \\
\text { dos resultados para apresentá-los aos outros membros da EMSI; }\end{array}$ \\
\hline & $\begin{array}{l}\text { - realizar acompanhamento e orientação sobre alimentação, atividades } \\
\text { físicas, consumo de álcool e tabaco; }\end{array}$ \\
\hline & $\begin{array}{l}\text { - acompanhar o tratamento medicamentoso de pacientes cadastrados } \\
\text { no HIPERDIA, observando e orientando sobre posologia prescrita pelo } \\
\text { médico, regularidade de uso, data de vencimento dos medicamentos e } \\
\text { necessidade de renovação da prescrição. Observar e registrar possíveis } \\
\text { efeitos colaterais, bem como as dúvidas dos pacientes e prover } \\
\text { informações regulares para os outros membros da EMSI; }\end{array}$ \\
\hline & $\begin{array}{l}\text { - medir mensalmente o peso e altura, calcular IMC, e orientar controle ou } \\
\text { perda de peso, nos casos de sobrepeso e obesidade; }\end{array}$ \\
\hline & - verificar uso de tratamento tradicional e seus efeitos; \\
\hline
\end{tabular}




\section{Quadro 12 - Atribuições do AIS em APS nos DSEls construído no CTACIS (continuação)}

\begin{tabular}{|c|c|}
\hline Atribuições do AIS & Atividades sugeridas \\
\hline \multirow{3}{*}{$\begin{array}{l}\text { Prevenção e controle } \\
\text { de portadores } \\
\text { de hipertensão e } \\
\text { diabetes* }\end{array}$} & $\begin{array}{l}\text { - revisar periodicamente os pés e feridas em pessoas diabéticas, efetuando } \\
\text { orientações quando necessário. Na ocorrência desses agravos, informar } \\
\text { outros membros da EMSI; } \\
\text { - observar sinais e sintomas de alerta de crise hipertensiva, orientando } \\
\text { sobre as principais medidas a serem tomadas. Informar imediatamente } \\
\text { os outros membros da EMSI sobre esses eventos; frente a sinais de alerta } \\
\text { solicitar remoção; }\end{array}$ \\
\hline & $\begin{array}{l}\text { Manter um registro regular das informações sobre o rastreamento e } \\
\text { acompanhamento de suspeitos e casos confirmados de hipertensão e } \\
\text { diabetes. Apresentá-los mensalmente aos outros membros da Emsi; }\end{array}$ \\
\hline & $\begin{array}{l}\text { Realizar discussões comunitárias sobre as medidas de prevenção e controle } \\
\text { de diabetes e hipertensão, qualidade e quantidade de alimentos e refletir } \\
\text { sobre o processo de transição alimentar e segurança alimentar; }\end{array}$ \\
\hline \multirow{8}{*}{$\begin{array}{l}\text { Vigilância e controle } \\
\text { da malária* }\end{array}$} & $\begin{array}{l}\text { Realizar atividade educativa individual e coletiva sobre a prevenção e controle } \\
\text { da malária; }\end{array}$ \\
\hline & $\begin{array}{l}\text { Nas comunidades que possuem casos de malária, mas foram infectadas fora } \\
\text { de sua comunidade, o AIS pode realizar: }\end{array}$ \\
\hline & $\begin{array}{l}\text { - atividades educativas sobre o controle de vetor e medidas de prevenção } \\
\text { de malária a serem adotadas quando as famílias viajarem para área de } \\
\text { risco de malária. Orientar também sobre sinais, sintomas e tratamento; }\end{array}$ \\
\hline & $\begin{array}{l}\text { - organizar periodicamente mutirões comunitários para busca de } \\
\text { criadouros de mosquitos nas áreas próximas das moradias e locais mais } \\
\text { frequentados pela comunidade, como roças e outros. Realizar eliminação } \\
\text { de criadouros, se necessário; }\end{array}$ \\
\hline & $\begin{array}{l}\text { - acompanhar as pessoas que retornaram de viagem a áreas com } \\
\text { transmissão de malária, efetuando identificação precoce de sintomáticos. } \\
\text { Para estes realizar teste rápido e exame de gota espessa. Na positividade } \\
\text { do teste rápido e/ou do resultado da lâmina lida pelo polo-base, iniciar } \\
\text { tratamento, seguindo protocolo de controle da malária. Se necessário, } \\
\text { encaminhar; }\end{array}$ \\
\hline & $\begin{array}{l}\text { - para os casos confirmados preencher boletins de notificação, enviar } \\
\text { lâmina para revisão, solicitar kit completo de tratamento e efetuar } \\
\text { rastreamento dos demais familiares e/ou companheiros de viagem. Findo } \\
\text { o tratamento, coletar lâmina de verificação de cura (LVC) e enviar para } \\
\text { avaliação no polo-base. }\end{array}$ \\
\hline & $\begin{array}{l}\text { Nas comunidades com casos frequentes de malária e/ou com transmissão } \\
\text { autóctone o AIS deve: }\end{array}$ \\
\hline & $\begin{array}{l}\text { - realizar atividades educativas regulares sobre o controle de vetor (manejo } \\
\text { ambiental), medidas de prevenção de malária e orientação sobre sinais } \\
\text { precoces da doença; }\end{array}$ \\
\hline
\end{tabular}




\section{Quadro 12 - Atribuições do AIS em APS nos DSEls construído no CTACIS (continuação)}

\begin{tabular}{|c|c|}
\hline Atribuições do AIS & Atividades sugeridas \\
\hline \multirow{7}{*}{$\begin{array}{l}\text { Vigilância e controle } \\
\text { da malária* }\end{array}$} & $\begin{array}{l}\text { - realizar mutirões comunitários regulares para identificação e erradicação } \\
\text { de criadouros na comunidade e/ou locais frequentados como as roças } \\
\text { (em uso e roças velhas), locais de banho e outros; }\end{array}$ \\
\hline & $\begin{array}{l}\text { - orientar para a tomada de medidas de prevenção como uso de telas nas } \\
\text { janelas e uso de mosquiteiros impregnados; }\end{array}$ \\
\hline & $\begin{array}{l}\text { - realizar busca ativa de casos de malária por meio de teste rápido e } \\
\text { coleta de lâmina de gota espessa em sintomáticos febris e/ou contatos } \\
\text { familiares. Na positividade do teste rápido e/ou do resultado da lâmina } \\
\text { lida pelo polo-base, iniciar tratamento, seguindo protocolo de controle } \\
\text { da malária. Se necessário, encaminhar; }\end{array}$ \\
\hline & $\begin{array}{l}\text { - para os casos confirmados preencher boletins de notificação, enviar } \\
\text { lâmina para revisão, solicitar kit completo de tratamento e efetuar } \\
\text { rastreamento dos demais familiares e/ou companheiros de viagem. Findo } \\
\text { o tratamento, coletar lâmina de verificação de cura (LVC) e enviar para } \\
\text { avaliação no polo-base. }\end{array}$ \\
\hline & $\begin{array}{l}\text { - realizar ou participar de inquéritos, estendendo a busca ativa de caso } \\
\text { entre os assintomáticos. Tais atividades deverão ser planejadas e } \\
\text { incluídas nos planos de ação do polo-base, em acordo com os outros } \\
\text { membros da EMSI e órgãos de vigilância epidemiológica. Nesses casos } \\
\text { preencher a "Ficha de inquérito para identificação de malária". }\end{array}$ \\
\hline & $\begin{array}{l}\text { Manter um controle mensal do número de lâminas de gota espessa, testes } \\
\text { de malária realizados e casos positivos; }\end{array}$ \\
\hline & $\begin{array}{l}\text { Preencher os formulários disponibilizados pelo Sistema de Informação de } \\
\text { Vigilância Epidemiológica; }\end{array}$ \\
\hline \multirow{4}{*}{$\begin{array}{l}\text { Apoio ao controle } \\
\text { da hanseníase* }\end{array}$} & $\begin{array}{l}\text { Desenvolver ações educativas e de mobilização envolvendo a comunidade } \\
\text { (escolas, conselhos de saúde, associações de moradores, etc.), divulgando } \\
\text { a importância do autoexame para identificação de manchas suspeitas de } \\
\text { hanseníase e de combate ao preconceito; }\end{array}$ \\
\hline & $\begin{array}{l}\text { Identificar sinais e sintomas da hanseníase e encaminhar os casos suspeitos } \\
\text { para médico ou enfermeiro do DSEI; }\end{array}$ \\
\hline & $\begin{array}{l}\text { Acompanhar mensalmente os portadores de hanseníase, em tratamento e } \\
\text { orientá-los; }\end{array}$ \\
\hline & $\begin{array}{l}\text { Encaminhar contatos intradomiciliares para avaliação na unidade de saúde e } \\
\text { estimulá-los a realizar o autoexame, mesmo depois da avaliação; }\end{array}$ \\
\hline $\begin{array}{l}\text { Prevenção e controle } \\
\text { das infecções } \\
\text { sexualmente } \\
\text { transmissíveis* }\end{array}$ & $\begin{array}{l}\text { Discutir com as famílias e lideranças sobre a pertinência de realizar, na } \\
\text { comunidade, ações de prevenção das IST e uso de preservativos; }\end{array}$ \\
\hline
\end{tabular}




\section{Quadro 12 - Atribuições do AIS em APS nos DSEls construído no CTACIS (continuação)}

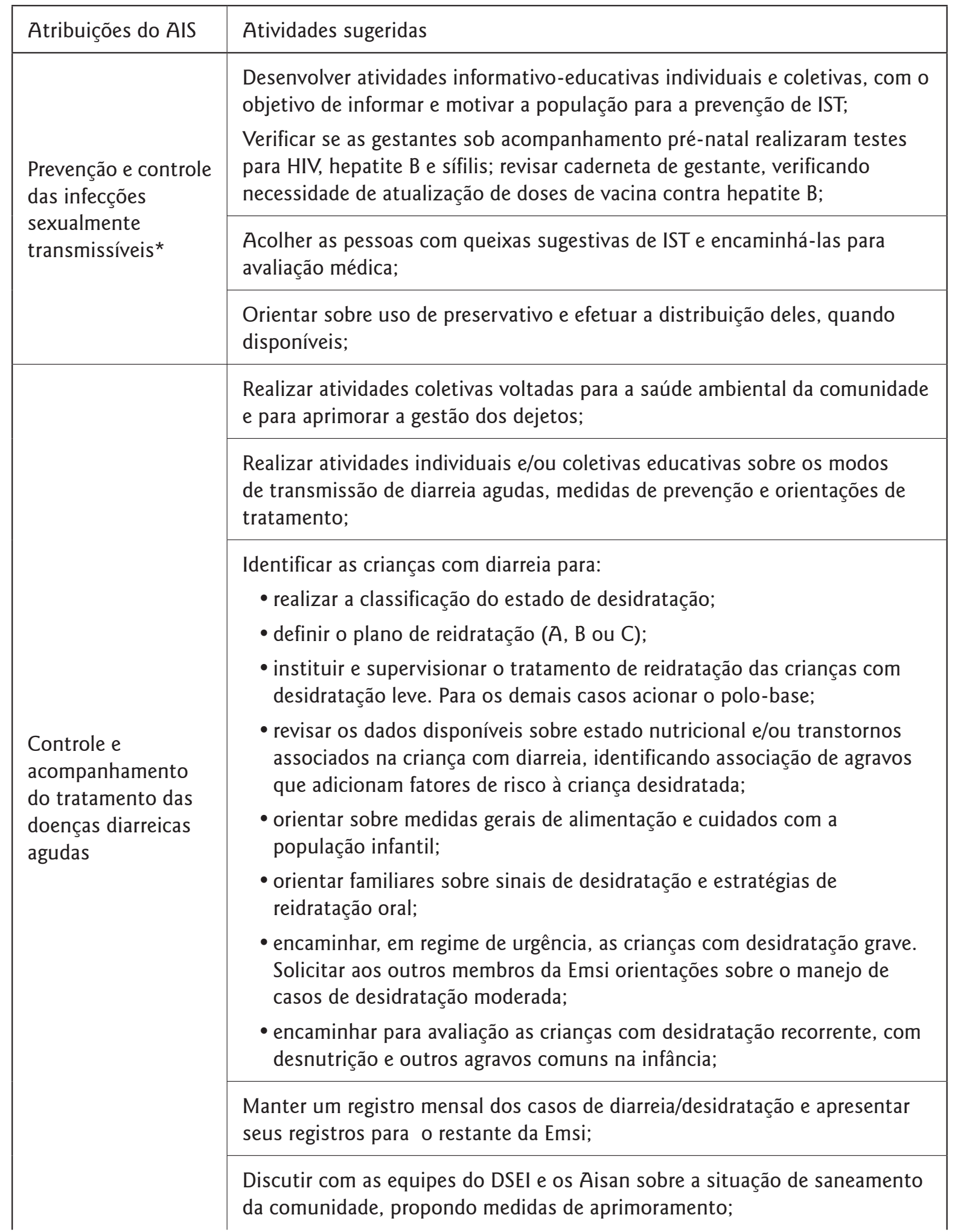




\section{Quadro 12 - Atribuições do AIS em APS nos DSEls construído no CTACIS (continuação)}

\begin{tabular}{|c|c|}
\hline Atribuições do AIS & Atividades sugeridas \\
\hline \multirow{8}{*}{$\begin{array}{l}\text { Controle e } \\
\text { acompanhamento } \\
\text { do tratamento } \\
\text { das infecções } \\
\text { respiratórias agudas }\end{array}$} & $\begin{array}{l}\text { Realizar atividades individuais e/ou coletivas educativas sobre os modos } \\
\text { de transmissão de infecções respiratórias agudas, medidas de prevenção e } \\
\text { orientações gerais de cuidados aos portadores desses quadros; }\end{array}$ \\
\hline & $\begin{array}{l}\text { Realizar a avaliação de pessoas com sintomas de infecções respiratórias } \\
\text { agudas para: }\end{array}$ \\
\hline & $\begin{array}{l}\text { - avaliação dos sinais vitais (temperatura, frequência respiratória e } \\
\text { frequência cardíaca); }\end{array}$ \\
\hline & $\begin{array}{l}\text { - classificar a infecção respiratória aguda em DRA, síndrome gripal ou } \\
\text { suspeita de pneumonia, instituindo condutas a serem adotadas com base } \\
\text { nos resultados da classificação; }\end{array}$ \\
\hline & • orientar medidas gerais de hidratação e tratamento; \\
\hline & • encaminhar casos suspeitos de pneumonia; \\
\hline & • encaminhar os sintomáticos respiratórios crônicos para avaliação; \\
\hline & $\begin{array}{l}\text { Manter registro mensal dos casos de IRA na comunidade e discutir os dados } \\
\text { com o restante da Emsi; }\end{array}$ \\
\hline \multirow{7}{*}{$\begin{array}{l}\text { Apoio ao } \\
\text { acompanhamento } \\
\text { de sintomáticos } \\
\text { respiratórios } \\
\text { e pessoas em } \\
\text { tratamento de } \\
\text { tuberculose* }\end{array}$} & $\begin{array}{l}\text { Realizar periodicamente o rastreamento de sintomáticos respiratórios } \\
\text { crônicos; }\end{array}$ \\
\hline & Encaminhar pessoas com tosse crônica para avaliação médica; \\
\hline & Orientar sobre a forma de coleta do exame de escarro dos casos suspeitos; \\
\hline & $\begin{array}{l}\text { Realizar visita domiciliar semanal para acompanhamento dos pacientes em } \\
\text { tratamento de tuberculose, fazer orientação alimentar e supervisionar o uso } \\
\text { correto dos medicamentos; }\end{array}$ \\
\hline & $\begin{array}{l}\text { Caso esteja implantado no DSEI, realizar o Tratamento Diretamente } \\
\text { Observado (DOT); }\end{array}$ \\
\hline & $\begin{array}{l}\text { Realizar pesagem mensal dos pacientes em tratamento subsidiar reavaliação } \\
\text { da dose pelo médico; }\end{array}$ \\
\hline & $\begin{array}{l}\text { Encaminhar para avaliação os comunicantes dos casos confirmados de } \\
\text { tuberculose; }\end{array}$ \\
\hline
\end{tabular}

* Atribuições desenvolvidas no CTACIS cujo processo pedagógico não foi descrito neste livro. 


\section{Referências}

BASTA, P. C.; ORELLANA, J. D. Y. \& ARANTES, R. Perfil epidemiológico dos povos indígenas no brasil: notas sobre agravos selecionados. In: GARNELO, L. \& PONTES, A. L. (Orgs.). Saúde Indígena: uma introdução ao tema. Brasília: MEC/ Secadi, Unesco, 2012.

BORGES, M. C. et al. Anemia among indigenous women in Brazil: findings from the First National Survey of Indigenous People Health and Nutrition. BMC Women's Health, 16(7): I-12, 2015.

BRASIL. Constituição Federal de 1988. Promulgada em 5 de outubro de 1988. Disponível em <http://www. planalto.gov.br/ccivil_03/constituicao/constituição. htm >. Acesso em: ago. 2019.

BRASIL. Fundação Nacional de Saúde. Política Nacional de Atenção à Saúde dos Povos Indígenas. Brasília: Ministério da Saúde, Fundação Nacional de Saúde, 2002.

BRASIL. Ministério da Saúde. Ministério da Educação. Referencial Curricular para o Curso Técnico de Agente Comunitário de Saúde. Brasília: Ministério da Saúde, Ministério da Educação, 2004.

BRASIL. Fundação Nacional de Saúde. Política Nacional de Saúde. Departamento de Saúde Indígena. A Formação de Agentes Indígenas de Saúde no âmbito da Política Nacional de Atenção à Saúde dos Povos Indígenas. Brasília: Ministério da Saúde, Fundação Nacional de Saúde, 2005.

BRASIL. Ministério da Saúde. Secretaria de Atenção à Saúde. Departamento de Atenção Básica. Política Nacional de Atenção Integral à Saúde do Homem: princípios e diretrizes. Brasília: Ministério da Saúde, Secretaria de Atenção à Saúde, Departamento de Ações Programáticas Estratégicas, 2008.

BRASIL. Ministério da Saúde. Política Nacional de Alimentação e Nutrição. Brasília: Ministério da Saúde, 2011.

BRASIL. Ministério da Educação. Catálogo Nacional de Cursos Téenicos. Brasília: Ministério da Educação, 2016.

BRASIL. Portaria 2436, de 21 set. 20I7. Revisa a Política Nacional de Atenção Básica. Diário Oficial da União, Brasília, 2017.

CAMILO, S. M. B. et al. Vigilância nutricional no Brasil: criação e implementação do SISVAN. Revista de Atenção Primária à Saúde, I4(2): 224-228, 201 I .

CANDAU, V. M. F. Educación intercultural crítica: construyendo caminos. In: TOMO, I. \& WALSH, C. (Orgs.). Pedagogías Decoloniales: prácticas insurgentes de resistir, (re)existir y (re)vivir. Quito: Ediciones Abya-Yala, 2013.

CARDOSO, A. M. et al. Prevalence of pneumonia and associated factors among indigenous children in Brazil: results from the First National Survey of Indigenous People's Health and Nutrition. International Health, 7(6): 4I2-4I9, 2015.

COELHO, L. C. et al. Sistema de vigilância alimentar e Nutricional/Sisvan: conhecendo as práticas alimentares de crianças menores de 24 meses. Ciência E Saúde Coletiva, 20(3): 727-738, 2015. 
COHN, C. Crescendo como um Xikrin: uma análise da infância e do desenvolvimento infantil entre os Kayapó-Xikrin do Bacajá. Revista de Antropologia, 43(2): 194-222, 2000.

COIMBRA JR., C. \& GARNELO, L. Questões de saúde reprodutiva da mulher indígena no brasil. In: MONTEIRO, S. \& SANSONE, L. (Orgs.). Etnicidade na América Latina: um debate sobre raça, saúde e direitos reprodutivos. Rio de Janeiro: Editora Fiocruz, 2004.

COIMBRA, C. E. A. et al. The First National Survey of Indigenous People's Health and Nutrition in Brazil: rationale, methodology, and overview of results. BMC Public Health, 13: 52, 2013.

DAHLGREN, G. \& WHITEHEAD, M. Policies and Strategies to Promote Social Equity in Health. Stockholm: Institute for Future Studies, I991.

DIEHL, E. E.; LANGDON, E. J. \& DIAS-SCOPEL, R. P. Contribuição dos agentes indígenas de saúde na atenção diferenciada à saúde dos povos indígenas brasileiros. Cadernos de Saúde Pública, 28(5): 819831, 2012.

ESCOBAR, A. L. et al. Diarrhea and health inequity among Indigenous children in Brazil: results from the First National Survey of Indigenous People's Health and Nutrition. BMC Public Health, 15: 191, 2015.

FERREIRA, L. O. Saúde e relações de gênero: uma reflexão sobre os desafios para a implantação de políticas públicas de atenção à saúde da mulher indígena. Ciência E Saúde Coletiva, 18(4): 1.151I.159, 2013.

FERREIRA, L. O. Interculturalidade e saúde indígena no contexto das políticas públicas brasileiras. In: LANGDON, E. J. \& CARDOSO, M. D. (Orgs.). Saúde Indígena: políticas comparadas na América Latina. Florianópolis: Editora da UFSC, 2015.

FUNDAÇÃO OSWALDO CRUZ, INSTITUTO LEÔNIDAS E MARIA DEANE E ESCOLA POLITÉCNICA DE SAÚDE JOAQUIM VENÂNCIO (FIOCRUZ, ILMD $\varepsilon$ EPSJV). Alto Rio Negro: ensino médio indígena integrado à educação profissional. Relatório Final do Curso Técnico de Agente Comunitário Indígena de Saúde (CTACIS). Manaus, 2016.

GEERTZ, C. A Interpretação das Culturas. Rio de Janeiro: LTC, 2008.
HORTA, B. L. et al. Nutritional status of indigenous children: findings from the First National Survey of Indigenous People's Health and Nutrition in Brazil. International Journal for Equity in Health, 12: 23, 2013.

INSTITUTO BRASILEIRO DE GEOGRAFIA E ESTATísTICA (IBGE). Censo Demográfico 2010: características gerais dos indígenas. Resultados do universo. Rio de Janeiro: IBCE, 2010.

LANGDON, E. J. Uma avaliação crítica da atenção diferenciada e a colaboração entre antropologia e profissionais de saúde. In: LANGDON, E. J. E GARNELO, L. (Orgs.). Saúde dos Povos Indígenas: reflexões sobre antropologia participativa. Rio de Janeiro: Contra Capa Livraria, Associação Brasileira de Antropologia, 2004.

LANGDON, E. J. A construção sociocultural da doença e seu desafio para a prática médica. In: BARUZZI, R. G. E JUNQUEIRA, C. (Orgs.). Parque Indígena do Xingu: saúde, cultura e histórica. São Paulo: Terra Virgem, Unifesp, 2005.

LEAL, A. F. L.; FIGUEIREDO, W. S. \& NOGUEIRADA-SILVA, G. S. O percurso da Política Nacional de Atenção Integral à Saúde dos Homens (PNAISH), desde a sua formulação até sua implementação nos serviços públicos locais de atenção à saúde. Ciência ESaúde Coletiva, I7(10): 2.607-2.6I6, 2012.

MACEDO, E. Currículo como espaço-tempo de fronteira cultural. Revista Brasileira de Educação, II (32): 285-296, 2006.

MAHER, D. \& COMETTO, G. Research on community-based health workers is needed to achieve the sustainable development goals. Bulletin of World Health Organization, 94: 786, 2016.

MENÉNDEZ, E. Modelos de atención de los padecimientos: de exclusiones teóricas y articulaciones prácticas. Ciência E Saúde Coletiva, 8(I): 185-207, 2003.

MONKEN, M. \& BARCELLOS, C. Vigilância em saúde e território utilizado: possibilidades teóricas e metodológicas. Cadernos de Saúde Pública, 2 I (3): 898-906, 2005. 
MOROSINI, M. V.; CORBO, A. D. \& GUIMARÃES, C. C. O agente comunitário de saúde no âmbito das políticas voltadas para atenção básica: concepções do trabalho e da formação profissional. Trabalho, Educação e Saúde, 5(2): 26 I-280, 2007.

PEDRAZA, D. Growth surveillance in the context of the Primary Public Healthcare Service Network in Brazil: literature review. Revista Brasileira de Saúde Materno Infantil, I6(I): 7-19, 2016.

RAFESTTIN, C. Por uma Geografia do Poder. São Paulo: Ática, 1993.

SILVA, J. A. \& DAlMASO, A. S. W. Agente Comunitário de Saúde: o ser, o saber, o fazer. Rio de Janeiro: Editora Fiocruz, 2001.

WALT, G. et al. Community health workers in national programmes: just another pair of hands? Philadelphia: Open University Press, 1990. 


\section{Leituras complementares}

\section{Publicações disponíveis na web, em números especiais de revistas e matérias relativas às diversas fases de implantação do Curso Técnico de Agentes Comunitários Indígenas de Saúde}

Agência de Notícias da Fiocruz, em 14 abr. 2009, sobre matéria da revista Radis em número especial sobre a implementação do Curso Técnico de Agentes Comunitários Indígenas de Saúde. Disponível em: < https://agencia.fiocruz.br/altorio-negro-\%C3\%A9-palco-do- I \%C2\%BA-curso-de-agente-comunit\%C3\%A I rioind\%C3\%ADgena-de-sa\%C3\%BAde>. Acesso em: 20 abr. 2009.

Publicação especial temática da Revista Poli - Saúde, Educação e Trabalho, por ocasião do seminário Povos Indígenas, Educação e Saúde: a formação profissional do agente indígena de saúde. A revista traz matérias sobre o panorama geral da questão indígena no Brasil, discussões sobre saúde e educação de povos indígenas no Brasil e em outros países da América Latina. Disponível em: < http://www.epsjv.fiocruz.br/sites/default/ files/revista_poli_-_l8.pdf $>$. Acesso em: 5 set. $201 \mathrm{l}$.

Revista RETS, que traz uma série de discussões sobre interculturalidade e sua relação com o tema da saúde, desde a formação de profissionais sensíveis aos diversos contextos culturais à formulação de políticas públicas. Disponível em: <www.rets. epsjv.fiocruz.br/sites/default/files/revistas/rets06_pt_0.pdf>. Acesso em: 15 jul. 2010. Especiais temáticos da revista Radis sobre as etapas do Curso Técnico de Agentes Comunitários Indígenas de Saúde. Foram duas edições especiais, uma no início do processo formativo e outra na finalização dele. Disponível em: <https://radis.ensp. fiocruz.br/index.php/todas-as-edicoes/80>. Acesso em: 14 maio 2009. Disponível em: <https://radis.ensp.fiocruz.br/index.php/todas-as-edicoes/I53>. Acesso em: 6 jun. 2015. 
Na revista Trabalho, Educação e Saúde, em 2009, os autores apresentam uma reflexão preliminar da experiência de implementação do Curso Técnico de Agentes Comunitários Indígenas de Saúde e os desafios do processo formativo em construção. Disponível em: <www.rets.epsjv.fiocruz.br/sites/default/files/formacao_tecnica_rio_negro.pdf $>$. Acesso em: 13 nov. 2009.

Estudo de caso da OMS sobre iniciativas sociais de inovação em saúde. O Curso Técnico de Agentes Comunitários Indígenas de Saúde foi o único representante do Brasil e o segundo da América do Sul. Disponível em: <https://socialinnovationinhealth.org/ case-studies/indigenous-health-agent-professionalization-programme-in-the-altorio-negro-region/>. Acesso em: 10 ago. 2015.

\section{Publicações sobre formação e trabalho do AIS}

O Agente Indígena de Saúde Xokleng: por um mediador entre a comunidade indígena e o serviço de atenção diferenciada à saúde - uma abordagem da antropologia da saúde, de Raquel Paiva Dias-Scopel. Dissertação de Mestrado, Florianópolis: Universidade Federal de Santa Catarina, 2005.

Raquel Scopel, em sua dissertação, traça o perfil de AIS xokleng, descreve as regras que operam na escolha de um AIS, suas atividades e a inserção na comunidade e dentro da Emsi. Estabelece uma correlação entre o modus operandi dos serviços de atenção à saúde e o modus vivendi dos xokleng, através de suas formas de apropriação e usos dos serviços de saúde com base em estratégias que se coadunam com sua visão de mundo, dinâmica e relações sociopolíticas.

Uma Etnografia das Práticas Sanitárias no Distrito Sanitário Especial Indígena do Rio Negro Noroeste do Amazonas, de Esron S. C. ROCHA. Dissertação de Mestrado, Manaus: Universidade Federal do Amazonas, 2007.

A dissertação de Esron Rocha é uma etnografia das práticas sanitárias desenvolvidas no DSEl Rio Negro, a partir da organização do trabalho dos profissionais de enfermagem: enfermeiro, técnico de enfermagem e agente indígena de saúde. $O$ autor analisa as práticas sanitárias do corpo de enfermagem do DSEI Alto Rio negro na oferta de atenção diferenciada à saúde e em interação com o AIS. Analisa também o perfil sociodemográfico e o processo de formação dos AIS baniwa, buscando apreender sua compatibilidade e/ou incompatibilidade com a política de atenção diferenciada do subsistema de saúde indígena. Os resultados obtidos mostram que os AIS baniwa enfrentam problemas ligados à baixa escolaridade e que seu processo de formação profissional pouco avançou após seis anos de implantação do DSEl. 
Expectativas emergentes: a inserção do agente indígena de saúde Xokleng na equipe multiprofissional de saúde indígena, de Raquel Paiva Dias-Scopel, Esther J. Langdon e Daniel Scopel. Tellus, 7( 13): 51-72, 2007.

O objetivo deste artigo é evidenciar algumas expectativas da relação entre o AIS e a Emsi de modo a contribuir criticamente para a compreensão das formas de como esse agente se insere na APS oferecida nas áreas indígenas. Os resultados obtidos demonstraram que a inserção do AIS na Emsi é limitada por uma hierarquia pautada na formação biomédica acadêmica e técnica; na comunidade, sua inserção é condizente com as formas de sociabilidade do grupo.

A participação dos agentes indígenas de saúde nos serviços de atenção à saúde: a experiência em Santa Catarina, Brasil, de Esther J. Langdon e colaboradores. Cadernos de Saúde Pública, 22(12): 2.637-2.646, 2006.

Esther J. Langdon e colaboradores analisam a formação e o papel do AIS nas terras indígenas Xapecó e Laklãnõ, Santa Catarina, Brasil, diante Política Nacional de Atenção à Saúde dos Povos Indígenas. O papel do AIS na Atenção Básica à Saúde é definido com base na mediação entre os saberes e práticas de atenção à saúde tradicionais e biomédicos, inseridos no conceito de atenção diferenciada.

O papel e a formação dos agentes indígenas de saúde na atenção diferenciada à saúde dos povos indígenas brasileiros, de Esther J. Langdon, Eliana Elisabeth Diehl $\&$ Raquel Paiva Dias-Scopel. In: TEIXEIRA, C. C. \& GARNELO, L. (Orgs.). Saúde Indígena em Perspectiva: explorando suas matrizes históricas e ideológicas. Rio de Janeiro: Editora Fiocruz, 2014.

Os autores avaliam, após 15 anos de existência do subsistema, a implantação, formação e participação dos AIS nas Emsis e sua contribuição para os serviços de atenção diferenciada à saúde, tendo como base a revisão de pesquisas sobre a implantação de serviços de atenção à saúde indígena com informações sobre o AIS.

La formación y el trabajo del Agente Indígena de Salud en el Subsistema de Salud Indígena en Brasil, de Ana Lucia de Moura Pontes e Luiza Garnelo. Salud Pública de México, 56(4): 386-392, 2014.

Pontes e Garnelo refletem sobre a figura do AIS no Brasil e o papel que desempenha esse agente no modelo de atenção diferencial ou intercultural. Segundo as autoras, os agentes não passam por processos de formação inicial, os cursos ocorrem com frequência irregular e os conteúdos enfocam somente a biomedicina. Há conflitos 
com a equipe e com a comunidade, o que gera sua desvalorização. $O$ agente não exerce a função de mediação esperada entre conhecimento e prática. A discussão sobre atenção diferenciada deve partir da relação entre o setor Saúde e o autocuidado.

\section{Vídeos}

Povos do Xingu Contra a Construção de Belo Monte. Disponível em: <www.youtube. com/watch?v=ZmOozYXozb8 >. Acesso em: 12 abr. 2014.

Mobilização dos povos indígenas do Xingu contra a construção de Belo Monte.

Bases para uma Nova Política Indigenista no Brasil. Disponível em: <www.youtube. $\mathrm{com} /$ watch? $\mathrm{v}=$ jqcdgtTAOH8Et $=638 \mathrm{~s}>$. Acesso em: $12 \mathrm{abr} .2014$.

Reflexão sobre a política indigenista no Brasil, com participação de lideranças indígenas e cientistas.

Nós Indígenas no Rio Negro - Parte I. Disponível: <www.youtube.com/watch?v=IX AVhYBhcusElist=PLefMZjHoKg8UXI0mGvBCK-uoCC0FD04j9>. Acesso em: 12 de abr. 2014.

Nós Indígenas no Rio Negro - Parte 2. Disponível em: <www.youtube.com/watch $? \mathrm{v}=$ wi3Ryzw2qC8Eindex $=2$ Elist $=$ PLefMZjHoKg8UXI0mGvBCK-uoCC0FD04j9>. Acesso em: 12 de abr. 2014.

Nós Indígenas no Rio Negro - Parte 3. Disponível em: <www.youtube.com/watch $? \mathrm{v}=\mathrm{Ij8GCsHiyes} \varepsilon$ list $=$ PLefMZjHoKg8UXI0mGvBCK-uoCC0FD04jgEindex $=3>$. Acesso em: 12 abr. 2014.

Nós Indígenas no Rio Negro - Parte 4. Disponível em: <www.youtube.com/watch $? \mathrm{v}=\mathrm{tMa} 4$ obpixbkEindex $=4 \xi$ list $=$ PLefMZjHoKg8UXI0mGvBCK-uoCC0FD04j9>. Acesso em: 12 abr. 2014.

Conjunto de vídeos institucionais da FOIRN e suas principais lutas após o momento de construção da Federação. É repleto de depoimentos de lideranças indígenas que refletem sobre o momento da fundação da Federação e o aprimoramento do movimento indígena no Rio Negro.

Políticas de Saúde no Brasil: um século de luta pelo direito à saúde. Disponível em: $<$ www.youtube.com/watch?v=YmUsySpi-GQ>. Acesso em: 07 fev. 2012.

Trajetória de construção do sistema de saúde ao longo da história, até chegar ao SUS. 
Encontro de Mulheres Indígenas da Bahia - Parte I. Disponível em: <https://www. youtube.com/watch?v=w-K4pVIVnDoEt=423s >. Acesso em: 07 fev. $20 \mathrm{I} 2$.

Apresenta o ponto de vista feminino sobre os problemas das mulheres indígenas e a necessidade de organização política. Serviu para despertar o interesse e subsidiar a discussão sobre o tema.

Das Crianças Ikpeng para o Mundo. Vídeo nas Aldeias, 200I. Disponível em: $<$ https://www.youtube.com/watch?v=28rlcj0xwEs >. Acesso em: 0I mar. 2013. Quatro crianças ikpeng apresentam sua aldeia respondendo à videocarta das crianças de Sierra Maestra em Cuba. Com graça e leveza, elas mostram suas famílias, suas brincadeiras, suas festas, seu modo de vida. Curiosas em conhecer crianças de outras culturas, elas pedem para que respondam à sua videocarta.

Xingu: três irmãos, dois mundos, uma missão, de Cao Hamburguer, 20II. Rede Globo e O2 Filmes. Disponível em: <https://www.youtube.com/watch?v=7V5nllkCypQ>. Acesso em: 01 mar. 2013.

Relata a trajetória dos irmãos Villas-Bôas na Expedição Roncador-Xingu, e como nesse processo os grupos indígenas, antes isolados, sofreram várias epidemias de gripe que mataram muitos deles e desestruturaram as comunidades. Assim, o filme contextualiza e pontua o início das atividades de vacinação nas aldeias.

Atitude de Vigilância Nutricional. VideoSaúde Distribuidora da Fiocruz, 1997. DVD. A operacionalização do Sisvan, recomendado pelo Ministério da Saúde, é um sistema de coleta e análise de dados da população para o monitoramento da situação nutricional, com o objetivo de conhecer os grupos de risco e criar subsídios para a erradicação desse problema.

Nutrição e Saúde. VideoSaúde Distribuidora da Fiocruz, 1997. DVD

Traz discussão sobre os cuidados com a saúde: da correta alimentação à higiene pessoal e coletiva.

"Cuidado com os alimentos industrializados". Reportagem do programa Vida $e$ Saúde, RBS TV, Porto Alegre, 2013. Disponível em: <https://www.youtube.com/ watch?v=0uJ3A8ndaqs $>$. Acesso em: 18 fev. 2013.

Alerta sobre os perigos dos alimentos industrializados. 


\section{Outros títulos da coleção Fazer Saúde}

O Nasf e o trabalho na Atenção Básica à Saúde: apontamentos práticos e experimentações

Túlio Romero Lopes Quirino, Fabiana Maria de Aguiar Bello Marques, Vick Brito Oliveira e Evelyn Siqueira da Silva (Orgs.), 2019

Pessoas com deficiência e doenças raras: o cuidado na atenção primária

Daniela Koeller Rodrigues Vieira (Org.), 2019

Saúde de migrantes e refugiados

Deisy de Freitas Lima Ventura e Veronica Quispe Yujra, 2019

Saúde na escola: intersetorialidade e promoção da saúde

Carlos dos Santos Silva, 2019

Avaliação nutricional na atenção básica: reflexões sobre práticas e saberes

Aline Alves Ferreira, Denise Cavalcante Barros e Ursula Viana Bagni (Orgs.), 2018

O jogo como prática de saúde

Marcelo Simão de Vasconcellos, Flávia Garcia de Carvalho e Inesita Soares de Araújo, 2018

Saúde no caminho da roça

Leonardo Cançado Monteiro Savassi, Magda Moura de Almeida, Mayara Floss e

Monica Correia Lima (Orgs.), 2018

Formato: $16 \times 23 \mathrm{~cm}$

Tipologia: Goudy Sans Light BT e Goudy Sans Medium BT

Papel: Pólen bold 70g/m² (miolo) e Cartão Supremo 250g/m² (capa)

CTP, impressão e acabamento: Imo's Gráfica e Editora Ltda.

Rio de Janeiro, setembro de 2019

Não encontrando nossos títulos em livrarias,contactar a Editora Fiocruz:

Av. Brasil, 4036, térreo, sala I 12 - Manguinhos

2 I 040-36 I - Rio de Janeiro, RJ

Tel.: (2 I) 3882-9039 e 3882-9007

Telefax: (21) 3882-9006

editora@fiocruz.br

www.fiocruz.br/editora 